\author{
UNIVERSIDADE DE SÃO PAULO \\ INSTITUTO DE ESTUDOS BRASILEIROS \\ PROGRAMA DE PÓS-GRADUAÇÃO \\ CULTURAS E IDENTIDADES BRASILEIRAS
}

RAQUEL NUNES ENDALÉCIO

A (re) construção do mundo clássico na obra de Monteiro Lobato: fontes e procedimentos

São Paulo

2013 


\author{
UNIVERSIDADE DE SÃO PAULO \\ INSTITUTO DE ESTUDOS BRASILEIROS \\ PROGRAMA DE PÓS-GRADUAÇÃO \\ CULTURAS E IDENTIDADES BRASILEIRAS
}

\title{
A (re) construção do mundo clássico na obra de Monteiro Lobato: fontes e procedimentos
}

\section{RAQUEL NUNES ENDALÉCIO}

Dissertação apresentada ao Programa de Pós-Graduação Culturas e Identidades Brasileiras

do Instituto de Estudos Brasileiros da Universidade de São Paulo, para a obtenção do título de Mestre em Filosofia.

Orientador: Prof. Dr. Marcos Antonio de Moraes

VERSÃO CORRIGIDA

O EXEMPLAR ORIGINAL ENCONTRA-SE DISPONÍVEL NA BIBLIOTECA DO INSTITUTO

DE ESTUDOS BRASILEIROS (IEB-USP)

São Paulo

2013 
DADOS DE CATALOGAÇÃO NA PUBLICAÇÃO (CIP)

Serviço de Biblioteca e Documentação do

Instituto de Estudos Brasileiros da Universidade de São Paulo

(c) reprodução total

Endalécio, Raquel Nunes

A (re) construção do mundo clássico na obra de Monteiro Lobato: fontes e procedimentos / Raquel Nunes Endalécio. -- São Paulo, 2013.

Orientador : Prof. Dr. Marcos Antonio de Moraes.

Dissertação (Mestrado) - Universidade de São Paulo. Instituto de Estudos Brasileiros. Programa de Pós-Graduação. Área de concentração: Estudos Brasileiros. Linha de pesquisa: Brasil: a realidade da criação, a criação da realidade.

Versão do título para o inglês: The (re) construction of the classical world in the works of Monteiro Lobato: sources and proceedings.

Descritores: 1. Lobato, Monteiro, 1882-1948 2. Grécia 3. Teoria literária 4. Crítica genética I. Universidade de São Paulo. Instituto de Estudos Brasileiros. Programa de Pós-Graduação II. Título. 
Para o maior dos meus amigos:

Jesus, o Deus Todo Poderoso. 


\section{AGRADECIMENTOS}

Louvo a Deus, pelo seu amor e misericórdia comigo em toda minha vida, especialmente nesses últimos anos.

Agradeço o apoio da Fundação de Amparo à Pesquisa do Estado de São Paulo (FAPESP), que mais uma vez, investiu na minha formação de pesquisadora.

Tenho tanto a agradecer a tantas pessoas! Começo então por algumas:

Agradeço a minha família, que sempre me amou e acreditou em mim, quando nem eu mesma acreditava. Amo muito vocês: Paulo Cesar, Gildete, João Paulo, Marcos Paulo Endalécio (s).

Agradeço às amigas que se fizeram irmãs, dividindo comigo bem mais que um apartamento: Manuella Maia Ribeiro, Rebeka Figueiredo da Guarda e Jussara Carvalho de Oliveira.

Muito obrigada às queridíssimas Jéssica Silva de Andrade, Piedade Soares, Priscilla Imperial e Fernanda de Oliveira - vocês são joias que ganhei de presente.

Ao casal Camila e Osmar Spagnoli por tantos anos de pesquisa e amizade.

Senhor Jônatas Amorim Henriques, obrigada pelo carinho, inestimável amizade e por me ensinar o que é comunhão.

Às valiosas sugestões das professoras Marisa Midori e Telê Ancona Lopez, no Exame de qualificação deste trabalho.

Querida professora Marisa Lajolo, obrigada pelas ideias, amizade e sábios conselhos.

Professor Marcos Antonio de Moraes, obrigada pelo rigor e cuidado tão importantes na pesquisa, pela imensa generosidade.

Agradeço muito aos queridos da Biblioteca Infantil Monteiro Lobato pela excelente assistência e saborosas tardes de conversas: Oiran Antonini, Azilde Lina Andreotti e Kazue Matuda Miura, um trio excepcional!

Aos queridos do IEB que sempre me ajudaram muito! (Desculpem, mas não conseguirei escrever o nome de todos!)

Aos professores e amigos do Mackenzie que acompanharam meu trabalho e me apoiaram em todo tempo. 
"neste mundo tudo está ligado a tudo, sonho, criação, obra. É o que nos vale, o trabalho ${ }^{1}$ (José Saramago).”

\footnotetext{
${ }^{1}$ SARAMAGO, J. História de uma flor. In: SARAMAGO, J. Outros cadernos de Saramago. Blog: 25 mai 2009. Disponível em: <http://caderno.josesaramago.org/2009/05/25/historia-de-uma-flor >. Acesso em: 23 out. 2012. Não paginado.
} 


\section{Sumário}

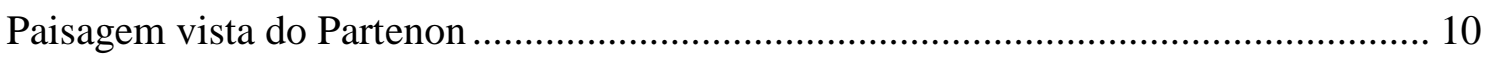

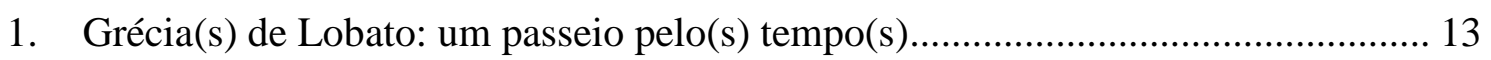

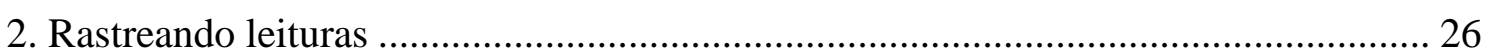

2.1. Olhares sobre a Grécia de Lobato.......................................................................... 26

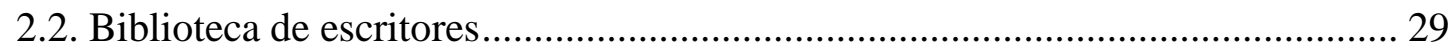

2.3. Livros dispersos e formação da Biblioteca de Lobato......................................... 34

3. Processo(s) de criação de Monteiro Lobato: leituras, diálogos e notas de trabalho 40

3.1. Monteiro Lobato \& William Durant ................................................................... 40

3.2. Monteiro Lobato \& Virgil Mores Hillyer........................................................... 59

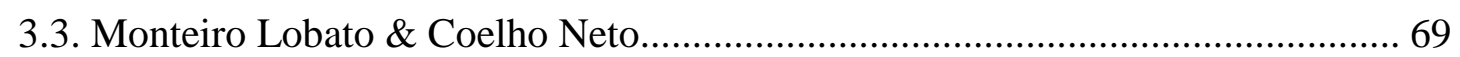

4. Minha Grécia de Monteiro Lobato: conclusão, reinício ........................................... 75

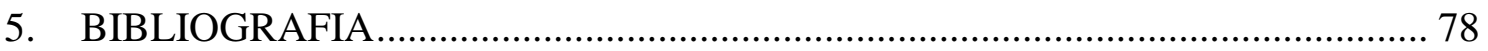

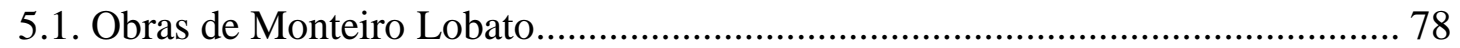

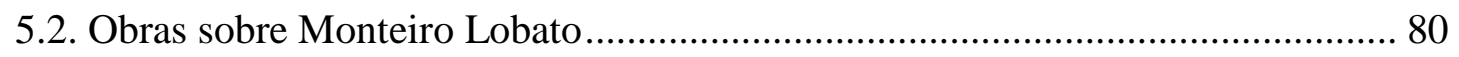

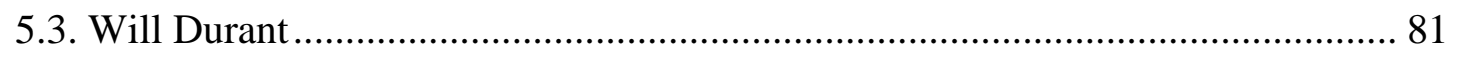

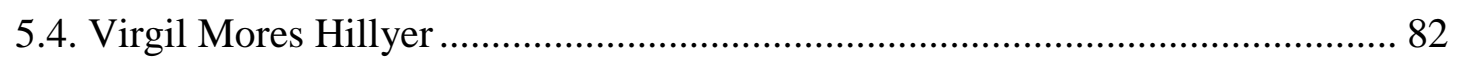

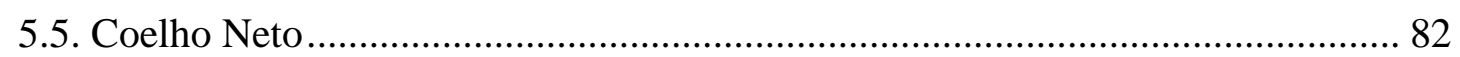

5.6. Crítica genética e Biblioteca de escritores............................................................ 82

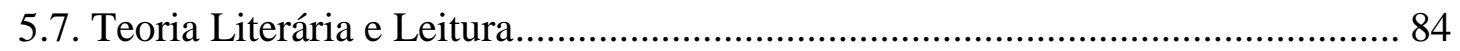

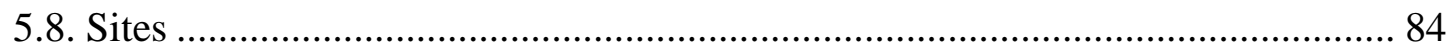

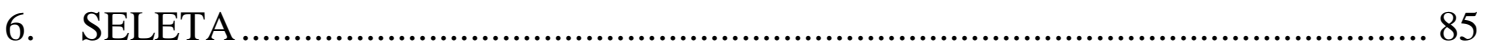

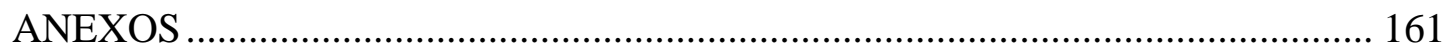

ANEXO 1: Carta da Companhia Editora Nacional relacionando títulos traduzidos por Monteiro Lobato (CEDAE, UNICAMP) ............................................................. 161

ANEXO 2: Páginas de “O Leão de Neméia” com anotações de Monteiro Lobato (Biblioteca Infantil Monteiro Lobato) ..................................................................... 163

ANEXO 3: Termo de Doação do Acervo Pessoal de Monteiro Lobato à Biblioteca Infantil Monteiro Lobato

ANEXO 4: Folha de rosto da $1^{\mathrm{a}}$ ed. de História da Civilização - Nossa herança

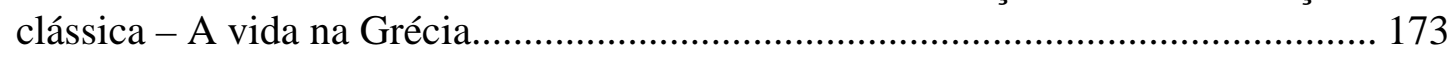

ANEXO 5: Prefácio de Os Grandes Pensadores .................................................... 175 


\section{Resumo}

Esta dissertação se propôs a estudar a presença da Grécia clássica e mitológica na obra do escritor Monteiro Lobato (1892-1948), buscando verificar como as referências ao mundo helênico se impuseram em diversos momentos de sua produção literária (adulta e infantil), jornalística e memorialística. Com o objetivo de detectar fontes bibliográficas do autor, a pesquisa recuperou títulos de livros de sua biblioteca particular, atualmente dispersa, bem como menções a obras focalizando a Hélade em sua correspondência e em outros documentos. Colocando em pauta os processos de criação literária, o trabalho abordou as relações intertextuais entre obras de Lobato e títulos do historiador Will Durant (1885-1981) e do educador Virgil Hillyer (18751931), ambos estadunidenses. Explorou também o diálogo epistolar do criador de

Urupês com o escritor maranhense Coelho Neto (1864-1934), reconhecido cultor da temática helênica. A dissertação apresenta "Seleta" de trechos da obra de Monteiro Lobato que focaliza aspectos históricos, linguísticos e culturais do mundo grego, a fim de contribuir para a ampliação do debate levantado.

\section{Palavras-chaves}

Monteiro Lobato; Grécia; intertextualidade, biblioteca de escritores; processo de criação. 


\begin{abstract}
This work has the proposal to study the classical Greece and the mythology presented in Monteiro Lobato's works (1892-1948), searching to verify how the references to the Hellenic world impose itself in several moments of his literary production (adult and young), journalistic and memorialistic. With the objective of detecting bibliography sources of the author, the research recovers book titles of his private library, nowadays fragmented, as the mentions of the works focusing the Helade in her correspondence and in other documents. Putting in question the literary processes of creation, this paper approaches the intertextual relations between the works of Lobato and the titles of the historian Will Durant (1885-1981) and the educator Virgil Hillyer (1875-1931), both North-Americans. It also explores the epistolary dialog of the creator of Urupês with the Maranhense writer Coelho Neto (1864-1934), recognized as the cultivator of the Hellenic theme. This paper presents "Seleta" of pieces of Monteiro Lobato's works that focuses in historical, linguistic and cultural aspects of the Greek world, in order to contribute to the expansion of the debate we raise here.
\end{abstract}

Key-words: Monteiro Lobato. Greece. Intertextuality. Writers' library. Creation process. 


\section{Paisagem vista do Partenon}

Meus primeiros passeios pela Grécia na companhia de Monteiro Lobato (18821948) começaram em 2006, quando, na graduação em Letras na Universidade Presbiteriana Mackenzie, participava de um grupo de pesquisa sobre a obra do autor. Depois de muitas leituras, conversas nas reuniões de trabalho, minha orientadora, a Profa. Dra. Marisa Lajolo, pediu que apresentássemos questões que pudessem fundamentar nossas pesquisas. Tendo lido O Minotauro, fiquei pensando, como teria sido possível um homem conhecer tanta coisa, com riqueza de detalhes, de uma época tão longínqua? Assim surgiu minha primeira questão: “De que fontes se valeu Lobato para a reconstrução do mundo clássico?” Essa indagação renderia uma primeira abordagem na iniciação científica “A (re) contrução do mundo clássico em O Minotauro e Os doze trabalhos de Hércules: fontes e procedimentos ${ }^{2 »}$, questão que vem sendo aprofundada nesta dissertação de mestrado.

A fim de conhecer e, de certa forma, "mapear” a Grécia lobatiana, realizamos nesta pesquisa, preliminarmente, a leitura da obra adulta, literatura infantil e da correspondência do escritor de Reinações de Narizinho, tendo em vista a realização de um levantamento exaustivo do assunto. Assim, no primeiro capítulo, “Grécia(s) de Monteiro Lobato”, buscamos apresentar relatos testemunhais do autor sobre a temática, bem como sinalizar algumas das formas pelas quais ele, em sua obra de ficção e memorialística, se apropria de personagens, mitos e eventos ligados ao mundo helênico para relacioná-los com aspectos da realidade do século XX.

O capítulo seguinte, "Rastreando leituras”, retoma a fortuna crítica de Lobato, para demarcar a singularidade da abordagem proposta neste trabalho, discute aspectos do processo de criação do escritor e recupera a história de sua biblioteca e arquivo pessoais.

Para entendermos o processo de (re)construção discursiva da Grécia de Lobato, recorremos a mais de um estudo e linha de pesquisa. A teoria literária forneceu instrumental crítico para interpretação da obra focalizada; os estudos históricos ofereceram dados para que a pesquisa pudesse compreender a retomada da Grécia na primeira metade do século XX; a crítica genética auxiliou na análise de manuscritos de

\footnotetext{
${ }^{2}$ Pesquisa com subvenção da Fundação de Amparo à Pesquisa do Estado de São Paulo, processo nº. 2007/54001-7 (set 2007- ago 2009).
} 
Lobato $^{3}$; o campo de estudos de "Biblioteca de escritores" deu subsídios para a compreensão de elementos do processo de criação do autor paulista. A noção de "biblioteca virtual” ${ }^{4}$ possibilitou uma proposta de reconstituição da biblioteca de Lobato por meio de suas indicações de leituras, referências em obras, "exemplares de trabalho" e outros documentos, já que a consulta à sua biblioteca material não é possível, pois se dispersou em grande parte; o conceito de "sistema literário" de Antonio Candido ${ }^{5}$ colocou em perspectiva crítica as relações de produção e circulação da obra, com o trabalho autoral e a recepção do leitor.

No capítulo "Processo(s) de criação de Monteiro Lobato: leituras, diálogos e notas de trabalho", buscamos reconstituir diálogos intertextuais entre "Monteiro Lobato \& William Durant”, bem como entre "Monteiro Lobato \& Virgil Mores Hillyer” e “Monteiro Lobato \& Coelho Neto”. Essas interlocuções mostram-se de grande importância não apenas na construção da Grécia lobatiana, como também na definição das preferências e concepções do autor brasileiro sobre literatura, história e suas relações com a educação.

Apresentamos nesta dissertação, na qualidade de Seleta, a transcrição de trechos relativos ao mundo dos gregos em livros de Lobato (Obra Adulta e Infantil); de excertos das cartas do escritor, reunidas em Em busca do "Lobato das cartas”: a construção da imagem de Monteiro Lobato diante de seus destinatários ${ }^{6}$, tese de Emerson Tin; de mensagens de leitores infantis sobre $O$ Minotauro, disponíveis no Instituto de Estudos Brasileiros - USP, textos transcritos por Raquel Afonso da Silva em sua tese ${ }^{7}$; de missivas de Coelho Neto para Lobato, matéria sob a guarda do CEDAE-Unicamp.

Entre os Anexos, documentação textual e iconográfica resultante da pesquisa, oferecemos o "Prefácio para a Tradução Brasileira” de Os Grandes Pensadores, de Will

\footnotetext{
${ }^{3}$ GRÉSILLON, Almuth. Elementos de crítica genética: ler os manuscritos modernos. Porto Alegre: Editora UFGRS, 2007. JACICSON, H.J. Marginalia: readers writing in books. New Itaven/ Londres. Yale University Dren, 2001. LOPEZ, Telê Ancona. “A Biblioteca de Mário de Andrade: seara e celeiro de criação”. In: ZULAR, Roberto (org). Criação em Processo: ensaios de crítica genética. São Paulo, FAPESP/ Iluminuras/ CAPES, 2002.

${ }^{4}$ LOPEZ, Telê Ancona. “A Biblioteca de Mário de Andrade: seara e celeiro de criação”. In: ZULAR, Roberto (org). Criação em Processo: ensaios de crítica genética. São Paulo, FAPESP/ Iluminuras/ CAPES, 2002.

${ }^{5}$ CANDIDO, Antonio. Formação da literatura brasileira: momentos decisivos , 1750-1880. 12 ed. São Paulo: Rio de Janeiro: Ouro sobre Azul, 2009. Cf. LAJOLO, Marisa. Literatura: Leitores \& Leitura. São Paulo: Moderna, 2007.

${ }^{6}$ TIN, Emerson. Em busca do "Lobato das cartas": a construção da imagem de Monteiro Lobato diante de seus destinatários. Campinas: Universidade Estadual de Campinas, 2007 (Tese de Doutorado), orientadora: Profa. Dra. Marisa Lajolo.

${ }^{7}$ Cartas transcritas em SILVA, Raquel Afonso de. Entre livros e leituras : um estudo de cartas de leitores. Campinas: Unicamp, Instituto de Estudos da Linguagem, 2009. (Tese de Doutorado); orientadora: Profa. Dra. Marisa Lajolo.
} 
Durant; carta de 1945 da Companhia Editora Nacional relacionando títulos traduzidos por Lobato; páginas “O Leão de Neméia”, com anotações de Monteiro Lobato; folha de rosto de A vida na Grécia; o termo de doação do Acervo Pessoal de Monteiro Lobato à Biblioteca Infantil que leva o nome do escritor, na capital paulista.

Assim, convidamos o leitor a conhecer o mundo clássico de Monteiro Lobato, tão encantador quanto o canto das sereias na ilha de Capri. 


\section{Grécia(s) de Lobato: um passeio pelo(s) tempo(s)}

A Grécia foi a verdadeira juventude a Imaginação Humana. Depois da Grécia essa imaginação foi ficando adulta e sem graça - lerda.(O Picapau Amarelo) ${ }^{8}$

Segundo Monteiro Lobato, o seu contato com a cultura clássica começou cedo. Aos 16 anos, em carta à mãe, D. Olympia, menciona a participação no debate escolar sobre “qual o maior guerreiro Carlos Magno ou César”:

No dia 13, houve sessão magna no Grêmio A. de Azevedo (que funciona aqui mesmo no colégio) e eu perante o colégio e o professorado todo, fiz um discurso sendo delirantemente aplaudido.// Agora, já não sou mais bobo como dantes, já faço discursos e até poesia! Vou defender tese no sábado: Qual o maior guerreiro Carlos Magno ou César? ${ }^{9}$

Ao que parece, esses primeiros contatos foram durante as aulas de Latim. O rapaz escreve à mãe:

Entro em Latim esta semana ou no começo e da outra se Deus quiser e o compadre Freire não mandar o contrário. ${ }^{10} / / \mathrm{O}$ Sr. Antônio dos Santos (que também é lente no Ginásio) é um dos diretores. É tão bom e manso, que na aula de Latim fazem dele o que querem. É a aula mais barulhenta.// Contei a ele ontem que fora reprov. em Latim e ele pediu-me muitas desculpas, dizendo que não foi por causa dele. ${ }^{11}$

Mas se a cultura clássica foi apresentada a Lobato ainda na juventude, ela nunca o deixou, acompanhando-o em diversas fases de vida. Emoções e afetos como agressividade, amores platônicos e sexualidade são compartilhados em carta por meio de símbolos gregos.

Dirigindo-se ao amigo Lino Moreira, em 1902, Lobato comenta a intempestiva carta que dele recebera; na mensagem, refere-se a Hércules, semideus da mitologia grega, filho de Zeus e da mortal Alcmena:

\footnotetext{
${ }^{8}$ LOBATO, Monteiro. O Picapau Amarelo. 7 ed. São Paulo: Brasiliense, 1957, p.66. Nesta dissertação, a transcrição de trechos da obra de Lobato seguiu a norma ortográfica vigente.

9 MONTEIRO LOBATO. Cartas Escolhidas. São Paulo: Brasiliense, 1959. p.48. Carta sem data, possivelmente de 1898. As citações apresentadas nesta dissertação seguem a ortografia vigente.

${ }^{10}$ MONTEIRO LOBATO. Cartas Escolhidas. São Paulo: Brasiliense, 1959. p.55 Carta datada de 25 jan. (possivelmente no ano de1899).

${ }^{11}$ MONTEIRO LOBATO. Cartas Escolhidas. São Paulo: Brasiliense, 1959. p.59. Carta datada de 14 abr. 1899.
} 
Acabo de ler a tua carta - bárbara como uma Ode de Carducci fascinante de vibração, de fogo, de selvageria, semelhante a uma pedra duríssima que, malhada por Hércules desfaz-se num turbilhão de faíscas ${ }^{12}$.

Em narrativa divulgada em O Povo, jornal de Caçapava, cidade do interior de São Paulo, o escritor propõe, em 1903, um ideal grego de beleza feminina, apresentando a deusa Diana:

Em vez desses Jeovás quasímodos que a suja humanidade tanto venera, Edel rende culto unicamente à Forma Impecável. // É a mulher no corpo, porém não como as mulheres que por aí existem, uns amontoados de carne grotescamente desproporcionais, pernas curtas, bundas enormes; é mulher como Diana pagã que é para mim a obraprima da Hélade - alta, esguia de formas, nervosa, seios pequeninos em vez de úberes como têm em geral as mulheres; seios improdutivos, criados unicamente para a Beleza, sem nenhum fim imediato de utilidade que dispute às vacas o ofício de mamadeiras ${ }^{13}$.

A percepção da mulher e da sexualidade aparece como tema recorrente em diferentes escritos do jovem Monteiro Lobato, tendo a Grécia como parâmetro em vários deles.

Outro conto, do mesmo ano, “Tão Ingênua”, no referido jornal paulista, trata de Nisa, jovem ingênua e tentadora que se casa com um quarentão, sem ainda conhecer “os mistérios de Afrodite":

No dia em que Leonardo, já quarentão, ligou-se pelos sagrados laços do himeneu com a tentadora Nisa, houve na vila muita gente prática que murmurou uma série de: hum! Hum! Muitíssimos significativos. Nisa era um prodígio de carnes entontecedoras, um perigo para o asceta mais rijo e o próprio Xenócrates talvez se sentisse envolvido pelo capitoso perfume - odor di femina - que Nisa sutilmente exalava. E o garbo do andar? com que sedução caminhava compondo um rastio harmonioso de movimentos sensuais e empolgantes! Ah, Nisa! ah, filha de Psique! Entretanto Nisa era a ingênua mais perfeita da vila; um anjinho puro e inocente, de nenhum modo culpada do estranho ardor da volúpia com que a mente de Leonardo, um quase velho; não via na união do homem com a mulher um meio de legalizar os mistérios de Afrodite, via uma união amiga com a de irmã com irmã ${ }^{14}$.

\footnotetext{
${ }^{12}$ LOBATO, Monteiro. Cartas Escolhidas. São Paulo: Brasiliense, 1959. p. 63. Carta de 1902.

${ }^{13}$ Ibidem. p.98-99. Carta de 9 jul 1903.

${ }^{14}$ MONTEIRO LOBATO. Cartas Escolhidas. São Paulo: Brasiliense, 1959, p.135. Carta datada de 17 set. 1903.
} 
Em carta, em 1904, ao amigo Godofredo Rangel, Lobato afirma que, apesar de seu interesse pela literatura, abre mão de qualquer leitura, mesmo da "melhor tragédia" grega, pela companhia de uma moça:

Perguntas quantas horas "literalizo". Nem uma, meu caro, porque só leio o que me agrada e só quando estou com apetite. Não troco uma conversa com uma macaquinha (o sexo na mulher corrige a banalidade, no homem agrava-a diz Machado) pela melhor tragédia de Eurípedes, porque por mais banal que seja a moça é sempre mais humana que um livro - e o humano quer humano. ${ }^{15}$

Nesse mesmo ano, Lobato publica, sob o pseudônimo de Hélio Bruma, a narrativa "Em casa de Fídias”16, em O Minarete, de Pindamonhangaba. Discorre sobre o amor impossível do escultor grego Fídias por Aspásia - mulher do governante Péricles - personagens que ganhariam espaço em sua obra posterior. No conto, Fídias se vê completamente encantado pela beleza da moça e sofre em silêncio por ver o amor que ela devotava ao chefe de Estado.

Ainda sobre figuras femininas, Lobato escreve, no tempo do Minarete, "Duas dançarinas”, no qual compara Felyne Verbist e Carmem Lídia ${ }^{17}$ a figuras da época de Péricles. Exalta as dançarinas: ${ }^{18}$

E diz-se, é lá possível, a graça natural, espontânea, não aprendida em conservatórios, de uma Felyne. Flor moça de carne, requinte supremo da civilização que prende a alma latina à germânica e, debruçada sobre os séculos, dá as mãos e cochicha com a terra de Péricles? A terra banhada de um sol sem manchas em que Terpsícore, descida do Olimpo, vinha às margens do Iliso ensinar à juventude a arte do movimento harmônico, ponto de fusão de dois ritmos - música e escultura? ${ }^{19}$

Carmem Lídia é um caso desses. Criança de Atenas, por estranha aberração desabrocha no Pátio dos Milagres deste povo feio e mazorro. Ela dança como lá se dançava - por injunção de uma vis insita.// Seus gestos, sua vidinha de 13 anos, suas ideias, seus caprichos de menina, seu andar, sua estesia inconsciente em via de cristalização, tudo nela se coa através do instinto heleno de beleza.// A eurritmia - a perfeição do equilíbrio - é seu modo de ser. Ouvi-la, vê-

\footnotetext{
${ }^{15}$ LOBATO, Monteiro. A Barca de Gleyre: Quarenta anos de correspondência literária. São Paulo: Cia Editora Nacional, 1944. p.25. Carta datada de 10 jan. 1904.

${ }^{16}$ Apresento em Anexo o conto, bem como outros trechos de Literatura de Minarete com referência à Grécia.

${ }^{17}$ Edgard Cavalheiro faz referência às duas bailarinas em Monteiro Lobato: vida e obra.

${ }^{18}$ Os trechos referentes às figuras gregas do conto "Duas dançarinas" estão transcritos na Seleta.

${ }^{19}$ LOBATO, Monteiro. Literatura de Minarete. São Paulo: Brasiliense, 1959, p.329.
} 
la, é ter a sensação de que se nos defronta não uma criatura singular, porém uma época. E que época! A Grécia de Péricles ${ }^{20}$.

A Grécia se faz presente, em principal, nas leituras de Monteiro Lobato. Lembremos que no início do século XX, época em que Lobato estudava, a presença da cultura grego-latina era forte, incorporada por autores de grande repercussão no meio literário, como o "último heleno” Coelho Neto.

Nos livros didáticos, de acordo com Lobato, era comum a apresentação de exemplos de heróis gregos. Em carta a Rangel, em 1904, Monteiro Lobato refere-se a prêmio recebido em um concurso de contos, à correção do título em francês dado à narrativa e aos exemplos que encontrava nas obras escolares de língua francesa:

Dizes que progredi no francês e é verdade: aprendi uma coisa. E sabes como? O Sílvio de Almeida, um dos juízes do concurso de contos, votou no meu, mas com uma advertência: "Primeiro lugar, apesar do título”. Sabe qual era o título do meu conto? Gens ennuyeuses!... Alguém lá da casa do Sílvio me deu a informação. Corei como romã e fui ao meu velho Sevène (Lembra-te? Calypso ne pouvait pas se consoler du départ d'Ulisses... "La rue du Savon" - "Pents-toi, Crillon, nouns avons [vaincu] et tu n'y étais pas") e verifiquei que "gens" em francês é macho e não fêmea, como pus no título. Voei á tipografia para fazer a correção. Era tarde... ${ }^{21}$

As leituras de Lobato sobre os clássicos não se limitavam às aulas de latim e aos livros didáticos. Em 1908, recém-formado pela Faculdade de Direito do Largo São Francisco, na capital paulista, o então jovem promotor público escreve, de Areias, ao amigo Rangel, contando que tinha começado a ler Homero. Na mesma carta, revela que estivera no Rio de Janeiro, cidade que considerava “contra-Grécia”, pois o "mulatismo" causaria no físico e no moral “uma feiúra”. Trata-se de longa exposição ideológica, em sintonia com as teses eugenistas da época, divulgada na primeira edição da Barca de Gleyre, em 1944:

É provável que já me tenhas incluído entre os amigos de cruzinha na frente, e me supunhas lá pelo Lethes a disputar com Caronte. Erro. Estou mas é em Areias e a ler Homero. Só agora, neste interregno de 50 dias que me separam do casamento, e reentrado nesta calmaria absoluta de Areias, é que tive oportunidade e mood de enfrentar o incomparável Homero - e lavo a alma das ditas impressões do mundo moderno com este desfile sem fim de criaturas 'belas como os deuses

\footnotetext{
${ }^{20}$ LOBATO, Monteiro. Literatura de Minarete. São Paulo: Brasiliense, 1959. p.330.

${ }^{21}$ LOBATO, Monteiro. A Barca de Gleyre: Quarenta anos de correspondência literária. São Paulo: Cia Editora Nacional, 1944. p.44. Carta datada de 3 nov. 1904.
} 
imortais’.// Que diferença de mundos! Na Grécia, a beleza; aqui a disformidade. Aquiles lá; Quasímodo aqui. Esteticamente, que desastre foi o cristianismo com a sua insistente cultura do feio!// Estive uns dias no Rio. Que contra-Grécia é o Rio! O mulatismo dizem que traz dessoramento de caráter. Dizem que a mestiçagem liquefaz essa cristalização racial que é o caráter e dá uns produtos instáveis. Isso no moral - e no físico que feiúra! Num desfile, à tarde, pela horrível rua Marechal Floriano, de gente que volta para os subúrbios, perpassam todas as degenerescências, todas as formas e má-formas humanas - todas, menos a normal. Os negros da África, caçados a tiro, trazidos á força para a escravidão, vingaram-se do português da maneira mais terrível - amulatando-o e liquefazendo-o, dando aquela coisa residual que vem dos subúrbios pela manhã e reflui para os subúrbios à tarde. E como vão apinhados como sardinhas e há um desastre por dia, metade daquela gente não tem braço ou não tem perna, ou falta-lhes um dedo, ou mostram uma terrível cicatriz na cara. 'Que foi?' 'Desastre da Central'. // Como consertar essa gente? Como sermos gente, no concerto dos povos? Que problemas terríveis o pobre negro da África nos criou aqui, na sua inconsciente vingança!... // Talvez a salvação venha de S. Paulo e outras zonas que intensamente se injetam de sangue europeu. Os americanos salvaram-se da mestiçagem com a barreira do preconceito racial. Temos também aqui essa barreira, mas só em certas classes e certas zonas. No Rio não existe. // Há tempos assisti em Taubaté a uma cena muito ilustrativa do que é essa defesa na América do Norte. Um americano desceu do trem e foi ao restaurante Pereira comer qualquer coisa. Sentou-se e pediu. Nisto entra um guarda-freio de boné na orelha, gaforinha, e senta-se-lhe ao pé. $\mathrm{O}$ americano ergue-se de impulso, atira a cadeira e some-se no trem. O país equiparava-o ao guarda-freio, mas ele não aceitava o presente. Filosoficamente me parece horrível isto - mas certo do ponto de vista racial. // A razão do meu silêncio está no meu andejismo. Em janeiro fiz mais de 2 mil quilômetros de trem, cavalo e navio. Andei mais que Telêmaco e se não encontrei Ulisses foi apenas porque não o procurei. $\mathrm{O}$ melhor desses passeios foi uma saída fora da barra a bordo do "Saturno", no dia da partida da esquadra americana. Primeiro vimo-la sair, do "Saturno" parado perto da fortaleza de Vilegaignon; depois fomos atrás por umas trinta milhas. Tivemos mar calmo, mar grosso, ventania e chuva - uma bela exibição de amostras. // E o "avança” que houve a bordo, na hora do lanche? Coisa inconcebível. Toda aquela gente fora convidada, e claro que era como se chama aqui "gente fina". Na hora de comer comportam-se como cães famintos que se atiram contra um montão de bofes. O carioca ri-se e diz: "É o avança”... Isso de educação coletiva, só a vejo na pobre gente da roça. $\mathrm{Na}$ "gente fina" do Rio de Janeiro não existe nenhuma... // Sabe alguma tradução de Homero em português? Leio na de Lecomte. ${ }^{22}$

Cabe assinalar que as edições seguintes do livro suprimem trecho da carta, a partir de "Estive alguns dias no Rio [...] a ponto de vista racial”. Desde a segunda

\footnotetext{
22 LOBATO, Monteiro. A Barca de Gleyre: Quarenta anos de correspondência literária. 1. ed. São Paulo: Cia Editora Nacional, 1944. p.132 - 134. Carta de 3 fev1908.
} 
edição, em $1946^{23}$, pela editora Brasiliense, a supressão é indicada por meio de uma linha pontilhada.

Brito Broca discute em A Vida Literária no Brasil 1900 como não só Monteiro Lobato, mas vários autores de sua geração se refugiaram na Grécia como maneira de reagir a "encrespação de mestiçagem”, num país em que o cativeiro marcara com violência a contribuição do sangue negro. O autor cita ainda o movimento científico da escola de Recife que, sob a influência germânica, via a mestiçagem como fator de decadência da nacionalidade. Sobre essa identificação com a cultura grega de alguns autores, Broca comenta:

O próprio Tobias Barreto, já em 1862, declarava: "Sou grego, pequeno e forte". Joaquim Nabuco, em carta a José Veríssimo, protestava contra o fato de se chamar Machado de Assis de mulato, dizendo: “A palavra não é literária, é pejorativa, basta ver-lhe a etimologia. De mais, o ser mulato em nada afetava sua caracterização caucásica. Eu pelo menos vi nele o grego." 24

Cabe lembrar ainda que Ronald de Carvalho, em sua Pequena História da Literatura Brasileira ${ }^{25}$, de 1919, procurou compreender a relação do "homem novo do Brasil” com a tradição clássica:

O homem novo do Brasil quer viver a realidade do momento. Ser moderno não é ser futurista nem esquecer o passado. Ninguém pode esquecer o passado. Repeti-lo, entretanto, seria fracionar artificialmente a realidade, que é contínua e indivisível. // Quem não admira o gênio ou o gênio romano? Mas se algum diretamente grecoromano quisesse impor à sociedade moderna, além das odes pindáricas e dos hexâmetros virgilianos, as concepções que fizeram a grandeza política de Atenas ou Roma, quantos minutos viveria fora da penitenciária? ${ }^{26}$

Retomando o fio que percorre os interesses de Lobato pela cultura grega, testemunhados em suas leituras, registra-se que escritor, em carta a Rangel, em 25 de fevereiro de 1908, deixa suas impressões sobre a Ilíada e a Odisseia de Homero, apontando a herança dessa literatura no cotidiano do Brasil no início do século XX:

\footnotetext{
${ }^{23}$ LOBATO, Monteiro. A Barca de Gleyre: Quarenta anos de correspondência literária. São Paulo: Brasiliense, 1946, p.207.

${ }^{24}$ BROCA, Brito. A Vida Literária no Brasil 1900. 5ed. Rio de Janeiro: José Olympio, 2005, p.158.

${ }^{25}$ Sobre A Pequena História da Literatura, Monteiro Lobato escreve resenha crítica no ${ }^{\circ}{ }^{4} 8$ da Revista do Brasil em 1919 em que a qualifica como "uma história da literatura brasileira que satisfaz plenamente”. Artigo inserido em Críticas e Outras Notas, p.36-37.

${ }^{26}$ CARVALHO, Ronald de. Pequena História da Literatura Brasileira. 4ed. Rio de Janeiro: F. Briguiet \& Cia, 1929, p. 412.
} 
Este mês de fevereiro foi o meu mês de Homero. Li a Ilíada e a Odisseia. Estou recheado de formas gregas, bêbado de beleza apolínea. Maravilhoso cinema, Homero! Gostei muito mais da Odisseia. A Ilíada peca pelo inevitável monótono do tema - a guerra ou, antes, o combate. De começo a fim, gregos e troianos morrerem como insetos, enquanto lá no Olimpo os divinos pândegos puxaram os cordéis e intrigam. Diodemes, Ájax, Aquiles, Heitor, Sarpedon racham crânios, estripam ventres, fendem ombros, decepam cabeças, rompem escudos, tomados duma horrível bebedeira de sangue. Aquiles é uma beleza. Páris, outra, mas de outro gênero. Já na Odisseia o assunto é caleidoscópio e sempre empolgante. Lê-se tudo aquilo como um romance de Maupassant. Penélope é ótima. Ulisses, um divino pirata. A descida aos "campos de asfódelos", deixa ver a origem da Divina Comédia. // Finda a leitura, pus-me a pensar no quanto Homero influenciou e influencia ainda hoje o pensamento ocidental.// Na linguagem corrente, quanto Homero, meu Deus! "Fulano é meu mentor", "o teu calcanhar de Aquiles", "astutos como Ulisses", a "teia de Penélope", "os encantos de Circe”, "entre Sila e Caribdes”. // Estou agora às voltas com a Eneida - mas pelo que já li, Virgílio está para Homero como o jornalista está para o escritor. ${ }^{27}$

Em anotações escritas possivelmente em $1902^{28}$ e divulgadas em Mundo da Lua, em 1923, o escritor lamenta a falta de traduções dos clássicos gregos para o português:

Toda a antiguidade greco-romana ainda nos está fechada. Não temos nossa tradução de Homero, de Sófocles, de Herótodo, de Plutarco, de Ésquilo. Como não temos Shakespeare, nem Goethe, nem Schiller, nem Molière, nem Rabelais, nem Ibsen. Falta-nos quase tudo, e isso por causa da vida inteligente que ainda é nossa. Sem enriquecimento material, sem desenvolvimento econômico, um povo não pode enriquecer-se espiritualmente. $^{29}$

Voltando a 1908, ano de produtivas leituras do jovem promotor da cidade de Areias, encontramos na folha de rosto de Histories d'Hérodote e Théatre d'Aristophane traduzida para o francês por André-Charles Brotier (1896), obra que pertenceu a Monteiro Lobato, atualmente no acervo do CEDAE-Unicamp, a indicação do escritor: “março 08” e “S. Paulo 08”. Tal nota sinaliza e sugere a relação entre leitura e as referências sobre o assunto em cartas e anotações.

Talvez pela necessidade do mercado editorial brasileiro de títulos clássicos traduzidos para o português, Monteiro Lobato tenha se dedicado tão intensamente às traduções. Em carta de 17 de setembro de 1945, a Editora Companhia Nacional

\footnotetext{
${ }^{27}$ LOBATO, Monteiro. A Barca de Gleyre: Quarenta anos de correspondência literária. São Paulo: Cia Editora Nacional, 1944. p.134-135. Carta de 25 fev. 1908.

${ }^{28}$ Segundo a “Justificativa” publicada em O Mundo da Lua [1923], os textos teriam sido escritos até a primeira década de 1900 - os vinte anos de Monteiro Lobato.

${ }^{29}$ LOBATO, Monteiro. Mundo da Lua e Miscelânea. 2 ed. São Paulo: Brasiliense, 1948, p.129.
} 
relaciona a pedido do escritor os títulos que traduziu, cerca de $70^{30}$. Nesse arrolamento, vinculando-se a assuntos do mundo clássico, encontram-se, entre outras obras, a História da literatura mundial, de John Macy, e a coleção História das civilizações, de Will Durant.

A prática de muitas leituras e traduções se impuseram grandemente em sua obra adulta e infantil. Lobato, em 1933 recupera a Grécia, a guerra de Troia e Homero em História do mundo para as crianças. Na obra infantil, no entanto, insere o assunto em um diálogo entre as personagens, de forma didática, como no trecho em que "Dona Benta ensina” Homero a Emília:

A história minuciosa da guerra entre gregos e troianos encontrase em dois poemas de grande fama. Um deles chama-se Ilíada, nome que vem do segundo nome de Troia, Ílion. O outro chama-se Odisseia. Neste conta-se o que, depois de terminada a guerra, se passou com um dos heróis gregos, Ulisses ou Odisseu. Sabem qual foi o poeta que compôs estes poemas?

- Camões! Gritou a burrinha da Emília.

- Homero, ensinou dona Benta. Homero era um rapsodo, quer dizer, um pobre diabo que andava pelas ruas cantando versos para viver, como fazem hoje os homens do realejo. Além do mais, cego, coitado - e por isso nunca escreveu os seus poemas. Foram escritos por outras pessoas que de tanto ouvi-los os guardaram de cor. Só depois da morte é que Homero ficou famoso. Nove cidades gregas passaram a disputar a honra de ter sido berço do cego, que em vida andava de porta em porta declamando seus poemas em troca de esmolas $^{31}$.

Segundo Lobato, a sua História do mundo para as crianças foi adaptada de Child's History of The World, publicada em 1924, por V. M. HILLYER ${ }^{32}$. Dona Benta traduz oralmente o livro para as crianças, dando grande destaque à história grega, referindo-se à mitologia, à Idade de Ouro (o chamado século de Péricles) e ao governo do "Grande Alexandre".

30 Carta em anexo. Disponível também em Monteiro Lobato (1882-1948) e Outros Modernismos Brasileiros: < http://www.unicamp.br/iel/monteirolobato/correspondencia_passiva.htm>. Acesso em: jan 2013.

${ }^{31}$ LOBATO, Monteiro. História do Mundo para Crianças. 3ed. São Paulo: Brasiliense. 1952, p.42.

${ }^{32}$ HILLYER, V.M. Child's History of The World. New York: Century, s/d. 
Depois do que aprendeu com Dona Benta sobre a Grécia, a boneca já possui bastante familiaridade com a cultura clássica e em Aritmética da Emília, obra de 1935, sai pelo sítio gritando:

- O Visconde achou! - O Visconde achou! Corram todos! O Visconde achou!

A gritaria foi tamanha que Dona Benta, Narizinho e Pedrinho acudiram em atropelo.

- Que foi? Que aconteceu?

- O Visconde achou! - repetia a boneca entusiasmada. - O danadinho achou!...

- Mas achou que coisa, Emília?

- Não sei. Achou, só. Quando entrei na sala, encontrei-o batendo na testa e exclamando: "Heureca!” Ora, Heureca é uma palavra grega que quer dizer "achei”. Logo, ele achou ${ }^{33}$.

Nos Serões de Dona Benta, de 1937, a avó conta histórias e mitos, entre os quais as lendas da "Grande Ursa" e da "Pequena Ursa”, a ninfa Calisto e seu filho Arcas, que foram transformados em constelações.

Calisto era linda e adorada por Zeus. Com ciúmes, a deusa Hera, esposa de Zeus, transformou a ninfa e seu filho em ursos para serem mortos por caçadores. Então, para defendê-los da esposa, o deus dos céus transformou-os em constelações. Depois de ouvir a história, um dos picapauzinhos já anuncia novas aventuras na Grécia:

- Interessante o mito, vovó. Um dia precisamos estudar a tal mitologia grega. Pelo que sei dela, é uma das coisas mais lindas que os poetas inventaram ${ }^{34}$.

Em O Picapau Amarelo, em 1939, Lobato introduz diversas personagens do mundo grego, e na interação delas com os moradores do sítio, os leitores familiarizamse com o assunto. Nessa mesma obra, “assanha” o leitor, noticiando o próximo livro da série infantil que teria por cenário a Grécia:

Dona Benta gostava de contar aos meninos coisas interessantes do mundo maravilhoso dos gregos.

- A Grécia povoou o mundo de deuses, semideuses, heróis e monstros, gigantes, ninfas, sátiros, faunos, náiades e mil coisas mais tudo lindo... Agora vamos lá apenas para um breve passeio - mas havemos de voltar para uma estadia longa. Ah, como vocês hão de apreciar a Grécia!...

\footnotetext{
${ }^{33}$ LOBATO, Monteiro. Aritmética da Emília. 1ed. São Paulo: Globo, 2009, p.14.

${ }^{34}$ LOBATO, Monteiro. Serões de Dona Benta. 22ed. São Paulo Brasiliense, 1994, p.74.
} 
O que Dona Benta ecoou foi o suficiente para assanhar os meninos. Emília só falava em morar lá toda a vida; Pedrinho fazia mil projetos; e Narizinho declarou que já de muito tempo seus sonhos eram só sobre a Grécia.

- Pois bem - declarou Dona Benta. Nossa próxima viagem de aventuras será pela Grécia - e dará um livro:

- Que lindo livro vai ser! - exclamou Emília. VIAGEM DO SÍTIO PELO OCEANO DA IMAGINAÇÃO GREGA.

- Comprido demais, Emília. Os títulos devem ser curtos, se não ninguém decora. Veja: OS LUSÍADAS, A ILÍADA, A ODISSEIA, O INFERNO, A ENEIDA..."35

Talvez toda essa “preparação” para O Minotauro, obra tirada do prelo em 1939, justifique o sucesso do livro e as inúmeras cartas enviadas por seus leitores ${ }^{36}$, como a carta da pequena Edite:

Meu caro amigo Sr. Monteiro Lobato.

Escrevo-lhe para felicitá-lo por seu novo livro: “O Minotauro”. Apesar de não haver lido "O Picapau Amarelo" gostei tanto da viagem feita pela Grécia Antiga, que queria qualificá-la em uma só palavra: MARAVILHOSA!!!

Os ensinamentos ali contidos são inúmeros; as piadas não só da Emília como dos outros, são muito engraçadas; os desenhos de Belmonte e de Rodolfo estão ótimos.

Enquanto não vi o "finis" do livro não sosseguei, pois que ele me deixava curiosíssima.

Agora vou pedir à livraria que mande vir "O Picapau Amarelo" que deve ser tão bom quanto o seu sequente. ${ }^{37}$

Quando Lobato trata da arquitetura em sua obra, a Antiguidade clássica se impõe como paradigma estético. Em América - livro que publicou depois de sua residência nos Estados Unidos, entre 1927 e 1931 - o protagonista da narrativa descreve o Memorial de Lincoln, vendo na edificação "linhas [...] gregas”:

Ergue-se à margem do Potomac esse templo grego de mármore branco, a refletir suas 36 colunas jônicas (cada qual representando um estado da União como era ao templo da morte do sublime Abe) no espelho do grande lago que o defronta. As linhas são rigorosamente gregas. Henry Bacon, o arquiteto, achou - e todos concordaram com o achado - que só a majestade das linhas helênicas poderia afinar com a majestade das linhas morais daquele homem [...]. Há o lago, um

\footnotetext{
${ }^{35}$ LOBATO, Monteiro. O Picapau Amarelo. 7 ed. São Paulo: Brasiliense,1957, p. 135-136.

${ }^{36}$ As cartas encontram-se depositadas no acervo do Instituto de Estudos Brasileiros - USP e estão transcritas em anexo. Cf. SILVA, Raquel Afonso de. Entre livros e leituras: um estudo de cartas de leitores. Campinas: Unicamp, Instituto de Estudos da Linguagem, 2009. (Tese de Doutorado).

${ }^{37}$ Carta de Edite Canto. IEB/ARAS. Cx.1 p2 doc15. Carta de Botucatu, 12 de Dez 1939.
} 
perfeito espelho retangular com moldura de grama, e cerejeiras, as quais na estação própria, japonizam de róseo o ambiente. Depois, a escadaria imensa com o templo grego no alto. Meus olhos poucas coisas ainda viram que emanasse maior beleza pura. Falharam na tentativa filósofos e estetas da mais subida acuidade. É sensação indefinível. Senti-a porém ali em toda plenitude. ${ }^{38}$

$\mathrm{O}$ alumbramento do personagem, descrito em América, assemelha-se àquele vivenciado por outro personagem lobatiano - agora em sua obra infantil. Dona Benta ao visitar o Partenon - templo grego do século V a. C - fica igualmente entusiasmada:

Diante do Partenão todos pararam, Dona Benta sem fôlego por ter subido a pé uns cem metros da casa de Péricles até o alto da Acrópole. [...] Dona Benta ergueu os olhos e viu. Viu o que nenhuma criatura moderna jamais viu. Viu o Partenão fresquinho ainda, com andaimes internos, cisco e lascas de mármore pelo chão. Viu e extasiou-se, porque era uma senhora de apurada educação artística. ${ }^{39}$

- Maravilha! - exclamou. Que dó não ter tal obra chegado aos tempos modernos! Estou notando uma coisa: a leve curvatura de todas as linhas retas, ou que deviam ser retas. Estas colunas convergem imperceptivelmente como se fossem reunir-se nas nuvens, e também noto leve curva nas arquitravas, no frontão, em tudo. ${ }^{40}$

É notável o conhecimento que Monteiro Lobato acumulou sobre a Grécia, sem nunca ter chegado a visitar as suas ruínas. Interessou-se por períodos da história helênica: o mitológico, em que figuram os deuses e semideuses da Antiguidade; e o de Péricles, em que se desenvolve a arquitetura e as grandes construções gregas como o século de Partenon. Curiosamente, fez Dona Benta compor um contraste entre as "duas Grécias”, a “antiga” e a do século XX:

Há duas - a Grécia de hoje, um país muito sem graça, e a Grécia antiga, também chamada de Hélade, que é a Grécia povoada de Deuses e semi-deuses, de ninfas e heróis, de faunos e sátiros, de centauros e mais monstros tremendos como a Esfinge, a Quimera, a Hidra, o Minotauro. Oh, sim, lá é que era a grande Grécia imortal. A de hoje só tem uvas e figos secos - e soldados de saiote. ${ }^{41}$

Lobato expressa em várias obras seu gosto pela figura e o governo de Péricles, pela voz de Dona Benta:

\footnotetext{
${ }^{38}$ LOBATO, Monteiro. América. São Paulo: Globo, 2009. p.49-50.

39 LOBATO, Monteiro. O Minotauro. 8 ed. São Paulo: Brasiliense: 1952, p. 57.

${ }^{40}$ Ibidem, p. 61.

${ }^{41}$ Ibidem, p. 02-04.
} 
“[...] e quem a lê [história de Péricles] admira-se de encontrar num mesmo homem tantos e tão grandes méritos. [...] era um homem de grande beleza física, dessas que se aproximam da beleza olímpica” ${ }^{42}$.

“A inteligência de Péricles pertencia à classe das verdadeiras, das que penetram no fundo das coisas e compreendem. Por isso foi o maior homem de seu tempo, o maior orador, o maior estrategista, o maior estadista que governou Atenas por vontade expressa do povo" ${ }^{43}$.

"Pois, apesar de tão longo tempo de ditadura - mas ditadura à moda grega, consentida pelo povo, anualmente renovada por vontade do povo..." ${ }^{44}$.

O escritor paulista parece tão submerso na cultura clássica que frequentemente estabelece relações entre a sociedade de seu tempo e o mundo grego. Ainda em América, na visita de seu personagem a Biblioteca do Congresso Americano, quando observa os deuses da Antiguidade desenhados por Mac Ewen, ele compara o americano a Hércules e a americana, a Ônfale ${ }^{45}$, rainha da Lídia:

- Alegria... - murmurei, contente de vê-la afinal tomada em conta. E foi sorrindo que me dirigi para o Corredor Sul, onde vi os heróis gregos pintados por Mac Ewen - Páris na corte de Menelau; Teseu abandonado Ariadne adormecida; Prometeu prevenindo seu irmão contra a malícia de Pandora; Aquiles ao ser descoberto por Ulisses quando se disfarçou em rapariga Minerva dando a Belerofonte o freio de Pégaso; Perseu com a cabeça de Górgora; Jasão mobilizando os argonautas para a conquista do tosão de ouro; Orfeu assassinado pelas Bacantes; o pobre Hércules segurando a roca de Ônfale... olhos.

- Hello, Mister Slang! - exclamei nesse ponto, arregalando os

- Isto aqui está o perfeito símbolo da América. O homem de cá, este Hércules, não faz outra coisa. Não acha a mulher americana uma perfeita Ônfale? ${ }^{46}$

E se entre seus primeiros textos já estava a temática grega, sua última grande publicação infantil apresenta as façanhas de um dos seus heróis preferidos: Hércules. Em carta ao amigo Antonio Annunziato, em 1944, Lobato compartilha a realização do projeto editorial de “12 livrinhos novos para o Natal”:

\footnotetext{
${ }^{42}$ LOBATO, Monteiro. O Minotauro. 8 ed. São Paulo: Brasiliense: 1952, p. 13.

${ }^{43}$ Ibidem, p.15-16.

${ }^{44}$ Ibidem, p. 16.

${ }^{45}$ Ônfale comprou Hércules como escravo por três talentos; após servi-la durante três anos, o herói se casou com a rainha.

${ }^{46}$ LOBATO, Monteiro. América. São Paulo: Globo, 2009. p.63.
} 
Ainda desta vez falhou minha ida para aí. Acumulou-se neste fim de ano trabalho de mais: 12 livrinhos novos, infantis: os Doze Trabalhos de Hércules, que estou acabando de fazer, à razão de um em três dias, a tempo de apanhar o Natal. E revisões, e o diabo. Só depois de tudo isso liquidado poderei ter o gosto de aceitar o amabilíssimo convite do amigo para uma quinzena no Prata, hospedado no Pavilhão da Imprensa. E me será muito útil esse descanso, porque o trabalho de escrever 12 livrinhos de 96 páginas em 36 dias está-me parecendo que é o Décimo Terceiro Trabalho de Hércules ${ }^{47}$.

Se a Grécia lhe serviu tantas vezes de parâmetro estético e referencial de cultura, Monteiro Lobato decidiu recriar em sua obra esse mundo, construído de diversas maneiras. Uma percepção idealizada ganha contornos na fala de seus personagens mais famosos:

- Que coisa gostosa viver na Grécia daquele tempo! - exclamou Pedrinho com suspiro de nostalgia.

- Sim, meus filhos. A vida lá era um prazer - era o prazer dessa liberdade que vocês gozam no sítio. O prazer de sonhar e criar a verdade e a beleza. Nunca houve no mundo tão intensa produção de beleza como na Grécia - e o que ainda há de beleza no mundo moderno é pálida herança da vida de lá.

- Viva o sítio do Picapau Amarelo da antiguidade - berrou Emília - e as ondas do mar, como um eco repetiram: Viva! Viva!.... ${ }^{48}$

${ }^{47}$ LOBATO. Monteiro. Cartas Escolhidas. São Paulo: Brasiliense, 1959, p. 134. Carta de 31 ago. 1944.

${ }^{48}$ LOBATO, Monteiro. O Minotauro. 8 ed. São Paulo: Brasiliense, 1952, p.18. 


\section{Rastreando leituras}

\subsection{Olhares sobre a Grécia de Lobato}

“A Grécia está no nosso idioma, no nosso pensamento, na nossa arte, na nossa alma; somos muito mais filhos da Grécia do que de qualquer outro país.” 49

A presença do mundo clássico na obra de Monteiro Lobato vem atraindo a atenção de muitos pesquisadores. Cinco recentes dissertações de mestrado se debruçaram sobre o assunto. A mitologia grega na obra $\mathrm{O}$ Minotauro de Monteiro Lobato (2006), de Ericka Sophie Bratsiotis ${ }^{50}$ sugere a intertextualidade entre $O$ Minotauro e textos de mitologia grega escritos por outros autores, ressaltando a ausência da figura de Teseu na obra lobatiana. Os doze trabalhos de Hércules: a estilização do mito na obra lobatiana (2006), de Diva de Oliveira ${ }^{51}$, realiza uma abordagem intertextual entre Os Doze Trabalhos de Hércules de Lobato, Héracles de Eurípedes e As Metamorfoses de Ovídio, apontando a dessacralização de Hércules na versão brasileira e a reconstrução do enredo helênico para aproximar o leitor do herói mitológico. Mitos gregos na literatura infantil: que Olimpo é esse? (2006) ${ }^{52}$, de Maria das Dores Soares Maziero, discute como os mitos gregos são apresentados na literatura infantil do século XX. Compara versões atuais dos mitos clássicos, dedicando ao criador de Emília o capítulo “Monteiro Lobato e os mitos gregos”; trata ainda do processo de criação lobatiano, por meio das traduções e adaptações dos clássicos, detectando procedimentos de intertextualidade ou paródia.

O Sítio do Pica-pau Amarelo da Antiguidade: singularidades das “Grécias” lobatianas (2007), de Juliana de Souza Topan ${ }^{53}$, aponta o historiador Will Durant como importante fonte grega de Lobato, indicando outras:

\footnotetext{
${ }^{49}$ LOBATO, Monteiro. O Minotauro. 8 ed. São Paulo: Brasiliense, 1952. p 103.

50 BRATSIOTIS, Ericka Sophie. A mitologia grega na obra O Minotauro de Monteiro Lobato. São Paulo: Universidade Presbiteriana Mackenzie, 2006. Dissertação de mestrado orientada pela Prof. ${ }^{a}$ Dr. $^{a}$ Maria Zélia Borges.

${ }^{51}$ OLIVEIRA, Diva de. Os doze trabalhos de Hércules: a estilização do mito na obra Lobatiana. São Paulo: Universidade Presbiteriana Mackenzie, 2006 Dissertação de mestrado orientada pela Prof. ${ }^{\text {a }}$ Dr. $^{\text {a }}$ Maria Luiza Guarnieri Atik.

52 MAZIERO, Maria das Dores Soares. Mitos gregos na literatura infantil: que Olimpo é esse? Campinas: Unicamp, Faculdade de Educação, 2006. Dissertação de mestrado orientada pela Prof ${ }^{\text {a }}$ Dra. Norma Sandra de Almeida Ferreira.

53 TOPAN, Juliana de Souza. O "Sítio do Pica-pau Amarelo da Antiguidade": singularidades das “Grécias” lobatianas. Campinas: Unicamp, Faculdade de Educação, 2007. Dissertação de Mestrado orientada pelo Prof. Dr. Joaquim Brasil Fontes Júnior.
} 
No CEDAE, foram encontrados alguns poucos volumes que apresentavam a história e a mitologia gregas, a maioria deles em línguas estrangeiras, como: Histoire d'Hérodote (1864), Théatre d’Aristophane (1896), Nueva Mitologia Ilustrada (1927) e História da Civilização - Nossa herança Clássica: a vida na Grécia (1943). Esse último foi o que mais me chamou a atenção, pois se trata de um livro de história antiga de um autor estadunidense, Will Durant (18851981), traduzido por Gulnara Morais Lobato, esposa de Edgard (filho mais velho de Monteiro Lobato) e revisada pelo próprio autor. ${ }^{54}$

A dissertação lança a hipótese de que nos últimos anos de sua produção literária, Lobato teria abandonado figuras do imaginário brasileiro, como o Saci, e teria se voltado aos temas europeus, talvez por uma decepção com as questões político-sociais do país, como a luta pela exploração do petróleo. No entanto, vale notar que a Grécia está presente na totalidade da produção do escritor não apenas em seus últimos livros. Juliana Topan elabora um quadro recuperando a presença da personagem Hércules em textos clássicos, como a Teogonia. A partir desses textos, analisa o herói (re)criado por Lobato. Compara ainda possíveis adaptações feitas pelo autor de Urupês, dirigidas ao público infantil. Assim, estabelece importante paralelo entre a Grécia criada por Monteiro Lobato e a apresentada pelos clássicos da literatura universal, tangenciando algumas de suas possíveis fontes, como o historiador americano Will Durant e o poeta francês Anatole France.

Mergulho na Hélade: mitologia e civilização grega na literatura infantil de Monteiro Lobato (2008), de Vitor Amaro Lacerda ${ }^{55}$, estabelece a relação entre a obra de temática grega de Monteiro Lobato e os clássicos como Ilíada, Odisseia e Teogonia. Lacerda evidencia Will Durant e Nietzche como fontes de leitura do autor brasileiro:

[...] talvez mais importante do que observar as fontes antigas conhecidas e lidas por Lobato seja nossa tentativa de enfatizar a importância de alguns autores que fazem a intermediação na sua relação com os gregos, destacando-se aí o filósofo alemão Friedrich Nietzsche e o historiador e professor de filosofia norteamericano Will Durant. $^{56}$

Will Durant, outro autor intermediário extremamente importante na compreensão da leitura que faz Lobato do mundo helênico (fato que

\footnotetext{
${ }^{54}$ TOPAN, Juliana de Souza. O "Sítio do Pica-pau Amarelo da Antiguidade": singularidades das "Grécias” lobatianas. Campinas: Unicamp, Faculdade de Educação, 2007. p. 43.

${ }^{55}$ LACERDA, Vitor Amaro. Um mergulho na Hélade: mitologia e civilização grega na literatura infantil de Monteiro Lobato. Belo Horizonte: UFMG, Faculdade de Letras, 2008. Dissertação de Mestrado orientada pelo Prof. Dr. Jacyntho José Lins Brandão.

${ }^{56}$ LACERDA, Vitor Amaro. Um mergulho na Hélade: mitologia e civilização grega na literatura infantil de Monteiro Lobato. Belo Horizonte: UFMF, Faculdade de Letras, 2008. p.11.
} 
também é reconhecido por Juliana Topan) e que, possivelmente, talvez também tenha intermediado suas leituras sobre o filósofo alemão. ${ }^{57}$

Tanto Juliana Topan quanto Victor Amaro sugerem, assim, a possível "presença” de Durant na obra lobatiana e nos indicam outras possíveis fontes das quais Lobato pode ter se valido. Contudo, devido à especificidade de seus temas, não se detiveram em uma análise mais profunda do o diálogo entre os autores e o processo de criação lobatiano, assuntos abordados nesta pesquisa.

Além das dissertações mencionadas, cabe recuperar recentes artigos que buscam lançar luz sobre o tema. Em 2008, O $13^{\circ}$ Trabalho de Lobato ${ }^{58}$, estudo de Emerson Tin, analisa a formação e transformação de Os Doze Trabalhos de Hércules (1944), buscando historiar as circunstâncias de elaboração do conjunto de 12 pequenos volumes (“livrinhos”59), publicados separadamente, com cerca de 100 páginas cada, e como se deu a reescritura dessas histórias, com a interação dos leitores.

No artigo A Paródia em Monteiro Lobato: adaptações clássicas $^{60}$, de 2009, Adriana Paula observa que algumas figuras na obra do escritor paulista são criadas a partir de outras já existentes na literatura. Sobre Hércules, comenta que "ao se retomar o mito clássico é perceptível a avaliação pejorativa feita da personagem uma vez que insinua que força e inteligência não sejam qualidades possíveis de um único indivíduo”. A autora afirma ainda que, apesar do resgate cultural ser marcado pelo humor, como em de Os Doze Trabalhos de Hércules, a paródia é uma forma de aproximar tradições e culturas distintas.

Roosevelt Araújo divulga, em 2009, dois artigos, “A Grécia pelos olhos de Emília: Lobato e sua leitura da Antiguidade Clássica” 61 e “A Grécia pelos olhos dos Picapaus: Lobato e sua leitura da Antiguidade Clássica”62. Neles, o autor sugere que Lobato, assim como outros autores do século XX, via a Grécia pelas lentes do chamado

\footnotetext{
${ }^{57}$ LACERDA, Vitor Amaro. Um mergulho na Hélade: mitologia e civilização grega na literatura infantil de Monteiro Lobato. Belo Horizonte: UFMF, Faculdade de Letras, 2008. p.74.

${ }^{58}$ LAJOLO, Marisa. (Org.); CECCANTINI, João Luis (Orgs.). Monteiro Lobato livro a livro (obra infantil). São Paulo: Editora Unesp/Imprensa Oficial, 2008.

${ }^{59}$ Cf. Seleta, entrevista de Lobato a Celestino Silveira e carta a Antonio Annunziato.

${ }^{60}$ SILVA, Adriana Paula dos Santos. A paródia em Monteiro Lobato: adaptações clássicas. In: CELLI Colóquio de Estudos Linguísticos e Literários. Maringá, 2009, p. 11-23.

${ }^{61}$ Artigo apresentado no $17^{\circ}$ Congresso de Leitura (COLE) da Universidade Estadual de Campinas em julho de 2009.

${ }^{62}$ Artigo publicado na Revista Letras, Curitiba, n. 78, p.85-95, mai/ ago 2009. Editora UFPR.
} 
“milagre grego”, segundo a qual “as realizações da Grécia Antiga não poderiam ser entendidas satisfatoriamente como uma simples sucessão de eventos históricos”. Nessa perspectiva de interpretação, Roosevelt sugere o diálogo de Lobato com Lecomte de Lisle, Ernest Renan, Anatole France e Will Durant.

Em 2011, Valter Pinheiro, no artigo “Arte grega clássica e arte moderna: aspectos axiológicos em $O$ Minotauro" ${ }^{63}$, avalia que, nessa narrativa infantil, a visão de Lobato sobre arte moderna é expressa por meio das falas de Dona Benta, do estadista Péricles e do escultor Fídias; a pesquisa compara essas percepções estéticas com aquelas presentes em Ideias de Jeca Tatu.

\title{
2.2. Biblioteca de escritores
}

\author{
É preciso remontar à Fonte - que não é a origem. A origem é, em \\ tudo, imaginária. A fonte é o fato aquém do qual o imaginário se propõe. A \\ água brota daí; embaixo, eu não sei o que acontece ${ }^{64}$.
}

Na procura das possíveis fontes de Monteiro Lobato sobre a Grécia, os pressupostos da Crítica Genética, em especial da vertente de estudos da Biblioteca de Escritores, têm nos valido como importante instrumental teórico. Segundo Telê Ancona Lopez:

Dentro da intertextualidade inerente à escritura moderna, em qualquer área do conhecimento, a análise de cunho genético das obras pode ultrapassar a crítica das influências, a constatação das fontes, ao se empenhar na recuperação dos sinais eclosão ou na verificação de amálgamas operados pelo ato criador, tangíveis na biblioteca, isto é, nas leituras de um escritor, de um filósofo, de um cientista, de um artista plástico ou de um cineasta. É hora, portanto, de focalizar as bibliotecas na complexa teia de obras (e de autores) "qui entoure et suscite l'acte de la création", que se estende em muitas direções. ${ }^{65}$

Assim, a partir dessa nova vertente nos estudos da intertextualidade, pensamos no processo de criação para além da relação de “influenciador/influenciado”, ou de que um determinado escritor, teoria, vertente foi responsável pela formação de certa obra ou autor. Antes, entendemos a criação como um processo que, muitas vezes, se inicia nas leituras que o escritor faz, deixando, nos livros e periódicos consultados, rastros na

\footnotetext{
${ }^{63}$ Texto publicado na Revista Fronteira Z, São Paulo, n. 6, abril de 2011.

${ }^{64}$ Paul Valéry, Cahiers, Ed.fac-similé. CNRS, 1957-1961, t.XXIII, p.592. apud. GRÉSILLON, Almuth. Elementos de crítica genética: ler os manuscritos modernos. Porto Alegre: Editora UFGRS, 2007.

${ }^{65}$ LOPEZ, Telê Ancona. "A Biblioteca de Mário de Andrade: seara e celeiro de criação”. In: ZULAR, Roberto (org). Criação em Processo: ensaios de crítica genética. São Paulo, FAPESP/ Iluminuras/ CAPES, 2002. p.46
} 
forma de anotações, mais ou menos sumárias, nas margens das páginas ou em folhas apensas.

Por meio da análise do conjunto dessas notas - marginália - podemos mapear, ou ao menos "fazer um croqui” de como um escritor se serviu de suas leituras: de que forma interagiu com elas?, quais foram suas anotações?, o que ele acrescentou ou acrescentaria, efetivamente, ali? e como isso aparece em sua obra? Sabemos, pois, que, por meio das anotações marginais, o escritor - ainda como leitor - interage com o texto impresso, deixa traços de suas ideias a respeito do assunto, traz novas interpretações, que lhe fazem sentido. Como observa J. H. Jackson:

As physical objects, books have changed in shape and texture over the years, but some features remain constant. As intellectual objects, they act upon - or rather interact with - the reader's responses to books, expressed in the marginalia, I try to bear these complementary claims in mind $[\ldots] .{ }^{66}$

Nesse sentido, tencionamos pesquisar a biblioteca lobatiana. No entanto, ao contrário do que acontece com o conjunto de livros reunidos por Mário de Andrade, conservado no Instituto de Estudos Brasileiros da Universidade de São Paulo, o acervo de Lobato dispersou-se.

Em 1946, antes de mudar-se para Argentina, Lobato doou parte do seu arquivo para o então jovem escritor e amigo Edgard Cavalheiro, que em 1955, a partir desses documentos, escreveria a biografia Monteiro Lobato: vida e obra. Cavalheiro historia o episódio:

Por fim, esclareceu que ia mesmo de mudança para a Argentina. Talvez não voltasse. Tinha uma papelada imensa, que de nada lhe servia, mas que lamentava botar fora, pois talvez se prestasse para reconstituir certa época da vida literária brasileira. Todo movimento intelectual do país passara pelas saletas da Rua Boa Vista, entre os anos de 1918 e 1925. Possuía milhares de documentos. Mas perdera os dois filhos homens. As mulheres não se interessavam por essas coisas... Finalmente parou e, olhando-me firme, fez a pergunta que sem dúvida trouxera engatilhada:

“- Quer ficar com o meu arquivo?”

\footnotetext{
66 JACKSON, H.J. “Introduction”, Marginalia: readers writing in books. New Haven/ Londres. Yale University, 2001.
} 
A pergunta, como é natural, deixou-me estatelado. Já havia visto parte desse material. [...] Não podia desconhecer o valor daqueles documentos nem a importância na vida mental do Brasil. Como responder, senão com um “Claro”! bem aberto, bem acolhedor?

Mas a conversa morreu aí. Lobato não falou mais do arquivo nem procurei forçá-lo a se lembrar do oferecimento. Um dia, porém, estaciona na porta um carro e dele começam a descarregar pacotes de papéis, acompanhados de curto bilhete: "Parto mesmo para a Argentina. Tudo arrumado. Estou desfazendo a casa. Aí vai a papelada... Haverá lugar?” 67

Se boa parte da "papelada” de Lobato havia ficado com Edgard Cavalheiro, para onde foram os livros da biblioteca lobatiana?

Parcela significativa de livros que pertenceram ao escritor encontra-se atualmente na Biblioteca Infantil Monteiro Lobato, em São Paulo, e no Centro de Documentação Cultural “Alexandre Eulálio” (CEDAE), no Instituto de Estudos da Linguagem, da Unicamp; outros volumes, na Biblioteca Nacional, no Rio de Janeiro. Portanto, por não termos a totalidade da biblioteca do escritor, trabalharemos aqui com a noção de “biblioteca virtual”, apresentada pela professora Telê Ancona Lopez, na qual se busca reconstituir o acervo bibliográfico do escritor por meio de suas indicações de leituras, referências em obras, exemplares de trabalho e outros documentos.

Dessa forma, nos debruçaremos não apenas sobre as obras que pertenceram à biblioteca de Monteiro Lobato, preservadas em diferentes instituições de pesquisa, como também buscaremos recuperar "pistas” de suas leituras a partir das referências feitas em obras publicadas, correspondência, cadernos de notas que pertenceram ao escritor. Tencionamos recompor, tanto quanto seja possível, a biblioteca lobatiana no que diz respeito ao mundo grego, assim como o seu processo de recriação do tema em sua obra.

Também levaremos em conta os “exemplares de trabalho” de Lobato ${ }^{68}$, ou seja, as reelaborações (acréscimos, supressões, substituições, etc.) que o escritor realizou nas páginas impressas de suas obras ${ }^{69}$, assim como as suas cadernetas de endereços. Essas

\footnotetext{
${ }^{67}$ CAVALHEIRO, Edgard. Monteiro Lobato: vida e obra. São Paulo: Nacional, 1955. p.13-14.

${ }^{68} \mathrm{O}$ termo, utilizado por Mário de Andrade, vem sendo estudado no Projeto Temático Processo de criação de Mário de Andrade nos manuscritos do seu arquivo, em sua biblioteca, sua correspondência, sua marginália e suas leituras (FAPESP), coordenado pela Profa. Dra. Telê Ancona Lopez, no IEB-USP.

69 Encontram-se em anexo imagens de algumas páginas de “O Leão de Nemeia”, um dos Doze Trabalhos de Hércules, com anotações autógrafas e datiloscritas do autor.
} 
agendas possuem o estatuto de “diário”, pois neles o escritor lançava, além de números de telefones e endereços, todo tipo de anotação como nome de autores, data de viagens, citações de livros, pensamentos etc.

Localizamos nove cadernetas que estão no acervo da Biblioteca Infantil Monteiro Lobato, todas digitalizadas na instituição, uma delas transcrita por Jéssica Silva de Andrade em sua pesquisa de iniciação científica "Documentação Primária e Processo de Escrita: a caderneta de endereços código 72 de Monteiro Lobato”, orientada pela Prof ${ }^{a}$ Dra. Marisa Lajolo, na Universidade Presbiteriana Mackenzie.

Sobre o hábito de Lobato em manter cadernetas de anotações, o biógrafo Edgard Cavalheiro testemunha:

Monteiro Lobato sempre tivera a mania do "diário", das pequenas notas sobre sensações que os fatos e acontecimentos lhe provocavam. [...] Um "Diário" conserva a imagem do nosso "EU" no passado, fomenta-nos, portanto, os instintos do nosso egoísmo, desse modo redobrando a sensação dos "eus" passados, isto é, das nossas fases evolutivas. Se um espelho comum já nos dá prazer, que valor não é um espelho retrospectivo que nos dê a cara dia a dia, pelo espaço de anos! O "Diário" é esse retrospecto da nossa inteligência". ${ }^{70}$

Em 1923, cabe lembrar que o escritor paulista divulgou em O mundo da Lua anotações várias feitas na juventude. Além desta publicação e das cadernetas, Lobato deixou registros em diários de outros escritores como em O Perfeito Cozinheiro das Almas deste Mundo (1992) ${ }^{71}$ de Oswald de Andrade. No diário coletivo, na garçonnière do autor de Memórias sentimentais de João Miramar, Lobato refere-se, de forma lúdica, ao escritor Léo Vaz:

Ventania buritisa-se [sic]. Bravo! Nota com enfado o Anafolismo do Léo. O Léo ficou no século 19, acredita em Renan e lê Anatole. Fora o Léo. Saint Barthelemy em cima dele! Biruta, esse já foi queimado vivo na fogueira da Santa Crítica.

As suas cinzas misturam-se com as da defunta Sra. Panóplia, assassinado pelo trovador dos Campos Elíseos. Foguinho extinguiu-se numa labaredinha literária - Escalas!

Monteiro Lobato

\footnotetext{
${ }^{70}$ CAVALHEIRO, Edgard. Monteiro Lobato: vida e obra. São Paulo: Nacional, 1955. p. 541.

${ }^{71}$ O livro foi publicado em 1987 em edição facsimilar pela editora Ex-Libris, e apoio do Instituto Moreira Sales. Em 1992, a transcrição do diário foi editado pela editora Globo.
} 
Acrescenta-se aos livros e às cadernetas, outra fonte importante para a reconstituição da biblioteca lobatiana: a vasta correspondência do autor. Sobre suas cartas, Lobato escreve ao amigo Rangel em 1943:

Fui mexer na minha tremenda papelada epistolar e tonteei. É coisa demais. É um mundo. Pus a Ruth separando aquilo e classificando por ordem de data - é o primeiro passo. O segundo será separar certas cartas, como as tuas, que são as mais numerosas; e como por milagre tenho aqui as minhas, estou vendo que desse passo vai sair coisa grossa e talvez muito interessante. Desconfio, Rangel, que essa nossa aturada correspondência vale alguma coisa. É o retrato fragmentário de duas vidas, de duas atitudes diante do mundo - e o panorama de toda uma época. Literatura, história e mais coisas. [...] Bom. Esta vai apenas para te comunicar que meti mãos á mina. Quando estiver tudo datilografado, você vai se assombrar, e verificar que éramos muito mais interessantes nos bastidores epistolares do que no palco - e juntos penetraremos na posteridade ${ }^{72}$.

Lobato demonstra ter consciência de sua importância no sistema literário brasileiro, assim como do valor de preservar esses documentos para que se pudesse reconstruir aspectos da história de uma época.

Os ensaios Amigos escritos: correspondência literária entre Monteiro Lobato e Godofredo Rangel de Suelli Cassal (2002) ${ }^{73}$ e Monteiro Lobato e a presença francesa em A barca de Gleyre (2007) de Ana Luiza Bedê ${ }^{74}$ são exemplos de pesquisa que se detêm nas leituras de Monteiro Lobato, a partir de sua epistolografia ${ }^{75}$.

\footnotetext{
${ }^{72}$ LOBATO, Monteiro. A Barca de Gleyre: quarenta anos de correspondência literária. 8 ed. São Paulo: Cia Editora Nacional, 1957. Carta datada de 5 set. 1943.

${ }^{73}$ CASSAL, Sueli Tomazini Barros. Amigos escritos: correspondência literária entre Monteiro Lobato e Godofredo Rangel. São Paulo: Imprensa Oficial do Estado de São Paulo/ Oficina do Livro Rubens Borba de Moraes, 2002. Cabe mencionar também o mestrado em processo de Camila Russo Spganoli, "Conversa em mangas de camisa! Monteiro lobato e a presença da leitura na formação do escritor" (Programa de pós-graduação em Estudos Brasileiros, Instituto de Estudos Brasileiros, Universidade de São Paulo; orientação da Profa. Dra. Telê Ancona Lopez).

${ }^{74}$ BEDÊ, Ana Luiza Reis. Monteiro Lobato e a presença francesa em A barca de Gleyre. São Paulo: Annablume/ Fapesp, 2007.

${ }^{75}$ Na edição da Barca de Gleyre de 2010 pela editora Globo, Vladimir Sachetta, biógrafo de Lobato, organizou um índice onomástico, o que facilita na localização dos autores lidos por Lobato.
} 


\subsection{Livros dispersos e formação da Biblioteca de Lobato}

Esta pesquisa pretende rastrear leituras de Monteiro Lobato que possam ter dado origem a percepções sobre o mundo clássico e recriações em sua obra. Para isso, recuperamos anotações do escritor em livros e periódicos de sua biblioteca.

Sabe-se que Monteiro Lobato doou alguns de seus objetos para a formação do “Museu da Emília”, hoje a Biblioteca Infantil que hoje leva o nome do autor, em São Paulo. Na introdução de Prefácios e Entrevistas, Marina de Andrade Procópio de Carvalho refere-se a "osso" da costela de Lobato, oferecido ao museuzinho organizado por Lenyra Fracarolli, então diretora da biblioteca:

Calei-me, e ao ouvir a palavra "osso" lembrei-me duma costela, cortada pelo Dr. Alípio e hoje no museuzinho da Biblioteca Infantil de Dona Lenira. ${ }^{76}$

Segundo Azilde Andreotti,

com a morte de Monteiro Lobato em 1948, a família doou alguns bens para a Biblioteca, que já havia iniciado um pequeno acervo do escritor, conhecido na época como Museu da Emília.

No entanto, há algumas discordâncias quanto à formação do acervo na Biblioteca Infantil. De acordo com Hilda Junqueira Vilela Merz, conhecida como Dona Hilda, leitora, amiga do escritor e funcionária da biblioteca entre 1982 e 1998, e com a pesquisadora Azilde Andreotti, o acervo pessoal do escritor teria sido incorporado à biblioteca logo após a morte dele:

Sobre o Acervo Monteiro Lobato é importante uma apresentação. Iniciado nos anos 30 com figuras de personagens infantis doados por Lobato e doações da família do escritor em 1948, esse acervo contém toda a obra de Lobato: as primeiras edições dos livros de literatura infantil, seus ilustradores, traduções, adaptações, documentos pessoais, farta correspondência, homenagens, artigos sobre o autor e sua obra, artigos escritos por Lobato em vários periódicos desde o início do século XX, livros e teses sobre Lobato, fotografias e alguns

\footnotetext{
${ }^{76}$ LOBATO, Monteiro. Prefácios e Entrevistas. 8 ed. São Paulo: Brasiliense, 1957.

77 ANDREOTTI, Azilde Lina. A formação de uma geração: educação para a promoção social e o progresso de país do jornal A Voz da Infância da Biblioteca Infantil Municipal de São Paulo (19361950). Campinas: Universidade Estadual de Campinas, 2004 (Tese de Doutorado), p.4.
} 
pertences seus em uma vitrine em exposição. São 3028 documentos abrangendo os vários aspectos da vida do autor e de sua obra. ${ }^{78}$

No entanto, em pesquisas na Biblioteca Infantil Monteiro Lobato, encontramos apenas um termo de doação da família de Lobato dirigido à Biblioteca datado de $1985^{79}$.

Conforme o depoimento de Azilde Andreotti, o restante do acervo do escritor em posse dos herdeiros não teria sido transferido para a biblioteca porque a instituição, na época, não possuía condições físicas para recebê-lo e que provavelmente iria para uma universidade:

Na época do Projeto Memória (1995 - 1996), tive informações de que a família de Monteiro Lobato não se dispunha a doar para a Biblioteca o restante do material do escritor, por não achar esse espaço o mais adequado. Provavelmente, o material seria doado para uma Universidade. Em dezembro de 2001, a família do escritor doou em comodato para o Centro de Documentação Cultural Alexandre Eulálio - CEDAE, vinculado ao Instituto de Estudos da Linguagem da UNICAMP, um acervo que ainda mantinha em seu poder. ${ }^{80}$

O acervo do escritor na Biblioteca Infantil é composto de "livros" ${ }^{\text {, }}$, cadernetas de anotações, cadernos de recortes organizados pela esposa de Lobato, cartas, artigos de jornais, além de objetos que pertenceram ao autor como material de pintura, exame médico, móveis de escritório etc.

Esta pesquisa localizou no acervo da Biblioteca Infantil Monteiro Lobato expressiva matéria que sinaliza possíveis fontes para a (re)criação do mundo clássico lobatiano:

\section{Livros:}

- DURUY, M.V. Histoire Grecque. s/ed. Paris: Hachette, s/d. (Com anotações de leitura de Monteiro Lobato);

\footnotetext{
${ }^{78}$ ANDREOTTI, Azilde Lina. A formação de uma geração: educação para a promoção social e o progresso de país do jornal A Voz da Infância da Biblioteca Infantil Municipal de São Paulo (19361950). Campinas: Universidade Estadual de Campinas, 2004 (Tese de Doutorado), p.10.

${ }^{79} \mathrm{O}$ termo de doação dos herdeiros de Monteiro Lobato à Biblioteca Infantil Monteiro Lobato encontra-se em anexo.

${ }^{80}$ ANDREOTTI, Azilde Lina. Op. cit., p.10.

${ }^{81} \mathrm{O}$ termo que formaliza a doação dos pertences de Lobato para a Biblioteca Infantil Monteiro não especifica a quantidade ou os títulos doados.
} 
- Grand Dictionnaire Universel du XIXe. Siècle. s/ed. Paris: Administration du Grand Dictionaire Universal, 1878. (Com anotações);

\section{Outros documentos:}

- Conjunto de páginas impressas, avulsas, de “O Leão de Nemeia”, um dos Doze Trabalhos de Hércules, com anotações marginais de Lobato.

O acervo do escritor na Biblioteca Infantil, contudo, necessita de pesquisa rigorosa, o que poderia ser facilitado por meio da digitalização de seus documentos e a sua disponibilização on-line, como já acontece em diversas bibliotecas como a Unicamp, que abriga outra parte significativa da biblioteca do escritor.

As obras que deram início ao acervo lobatiano na Unicamp foram encontradas “por acaso" ${ }^{82}$. Durante o mestrado, a pesquisadora Cilza Bignotto, deparou-se com alguns exemplares raros e primeiras edições da obra do escritor sendo vendidos em quiosque na banca de Luis Martins, em Santos, litoral paulista. Conversando com o livreiro, Cilza descobriu que ele havia comprado uma grande quantidade de livros da família de Newton Nebel dos Santos, dedicado colecionador de Lobato. Com apoio da Fapesp, Cilza adquiriu o acervo bibliográfico, que foi oficialmente incorporado ao CEDAE do IEL, passando a constituir a Biblioteca lobatiana.

A professora Marisa Lajolo, orientadora de Cilza, convidou os herdeiros de Monteiro Lobato (Sra. Joyce Lobato Campos e Sr. Dr. Jorge Kornbluh) para o evento de incorporação da “Coleção biblioteca lobatiana” à Unicamp. Esse foi o primeiro passo para a negociação relativa à transferência da documentação em posse dos herdeiros para a Universidade. Essa negociação foi concluída no segundo semestre de 2001. Em 5 de dezembro do mesmo ano, o acervo foi oficialmente incorporado ao CEDAE do IEL, passando a formar o Fundo Monteiro Lobato (FML), composto de livros, correspondência $^{83}$, documentos familiares originais, documentos de trabalho, e visuais (fotografias, pinturas e desenhos), recortes de jornal e alguns objetos. ${ }^{84}$

\footnotetext{
${ }^{82}$ Disponível em:

<www.unicamp.br/unicamp/unicamp_hoje/ju/abril2002/unihoje_ju173lobato_pag03.htm > . Acesso em: jul. 2011.

83 Cabe lembrar que um terceiro acervo, de grande importância para os estudos lobatianos, foi incorporado ao CEDAE em 2002: o Fundo Charles Franckie, que é composto por cartas de Charles
} 
Foram localizados, no FML, os seguintes documentos, possíveis matrizes lobatianas do mundo clássico:

\section{Livros $^{85}$ :}

- Histoires d'Hérodote (1864) de Pierre Saliat, com anotações marginais;

- Nueva Mitologia Ilustrada: documental, artística, literaria (1927) de M. Juan Richepan;

- The Stream of History (1929) de Geoffrey Parsens;

- Théatre D’Aristophane/ Traduction Français D’ André-Charles Brotier, revue et corrigée, précédée d' une introduction augmentée d'une notice sur chaque pièce por Louis Humbert (1896);

- DURANT, Will. História da Civilização. Vol. II. A Vida na Grécia. s/ed. São Paulo: Companhia Editora Nacional, 1943.

\section{Outros documentos:}

- Carta de Monteiro Lobato a Jurandir Ubirajara Campos, solicitando um desenho para capa de “Os Doze Trabalhos de Hércules”, edição de luxo da editora Acteon;

- Manuscrito com o título atribuído “Depois daquela viagem à Grécia...” e data atesta;

- Manuscrito com o título atribuído 'Revisão de tradução para o espanhol de “O Minotauro”, realizada por Ramon Pietro;

- Manuscrito, “As Ninfas de Emília” [1947] (10 páginas datilografadas com anotações autógrafas de Lobato);

- Manuscrito, “Os12 Trabalhos de Hércules” (1946). (1 página datilografada com anotações autógrafas de Lobato).

Franckie, dentre as quais se encontram cartas enviadas por e para Lobato na época em que juntos lutavam pelo petróleo no Brasil. Cf. CHIARADIA, Kátia. Ao amigo Franckie, do seu Lobato. Campinas: Unicamp, Instituto de Estudos da Linguagem, 2008. Dissertação de Mestrado orientada pela Profa. Dra. Marisa Lajolo.

${ }^{84}$ Parcela expressiva dos documentos do FML, assim como pesquisas resultantes da exploração dele, está disponibilizada por meio do site: < www.unicamp.br/iel/monteirolobato/>, vinculado ao Projeto Temático Monteiro Lobato (1882- 1948) e outros modernistas brasileiros, coordenado pela Prof ${ }^{a}$ Dra. Marisa Lajolo.

${ }^{85}$ Alguns livros não apresentavam a referência completa no catálogo do CEDAE, faltando indicações de editora, cidade, edição. 
Debruçando-nos assim, sobre a obra e a biblioteca do escritor, buscamos vestígios de seu processo de criação. Mas saber com exatidão a ordem cronológica dos textos criados por Lobato não é tarefa fácil. Por um lado, por seu material de trabalho não estar preservado integralmente em um acervo, e por outro porque os documentos por mais cuidado que se tenha - são organizados por outras pessoas em espaços e tempos diferentes do que foram originalmente produzidos.

Como exemplo, temos o manuscrito Depois daquela viagem à Grécia... [1920], conservado no acervo do CEDAE, com título e data atribuídos. O documento figurava como anexo a exemplar de A menina do Narizinho Arrebitado, que pertencera ao autor, obra publicada em 1920; logo se estimou que a data do manuscrito fosse a mesma da publicação do livro. O conto que narra a volta dos picapauzinhos à Grécia foi divulgado em diferentes edições de Fábulas, também com diferentes títulos, dentre os quais o escolhido. No entanto, o texto das Fábulas (1922) sofre diversas alterações e acréscimos nas edições posteriores; só a partir da $8^{\mathrm{a}}$, de $1943,{ }^{86}$ aparecem os comentários dos personagens do sítio, como registrado pelo autor no texto do manuscrito, o que sugere que sua data seja posterior à atribuída pelos pesquisadores.

Em uma carta ao amigo Cesídio Ambrogi, com data provável de $1942^{87}$, Lobato alude à preparação de uma nova edição de Fábulas, que seria, provavelmente, a $8^{\text {a }}$, tirada do prelo em 1943, a qual se apresentaria desbastada de "literatura". Na mensagem, traz à baila o romance Éramos seis, de Maria José Dupré, publicado nesse mesmo ano pela Editora Brasiliense, e para o qual Lobato fez um prefácio, aplaudindo a expressão literária desataviada da autora:

Estou preparando o meu livro Fábulas para nova edição, e sabe em que consiste o preparo? Em tirar todas as "coisas lindas" que inconscientemente lá botei, isto é, a "literatura". Estou raspando a literatura que há nessas fábulas. E como é doloroso! O mesmo que uma raspagem de osso! A gente fez aquilo com tanto amor, achou tão bonito, gostou tanto - e ainda acha tão bonito... E tem de votar fora, tem de raspar. Por quê? Por causa da tal Senhora Leandro Dupré. Esquisito, não? Passei a vida a lidar com a literatura, li todos os

\footnotetext{
86 SOUZA, Loide Nascimento de. "Monteiro Lobato e o processo de reescritura das fábulas". In: LAJOLO, Marisa. (Org.); Ceccantini, João Luis (Org.). Monteiro Lobato livro a livro (obra infantil). São Paulo: Editora Unesp - Imprensa Oficial, 2008.

${ }^{87}$ TIN, Emerson. Em busca do "Lobato das cartas": a construção da imagem de Monteiro Lobato diante de seus destinatários. Campinas: Universidade Estadual de Campinas, 2007. Tese de Doutorado orientada pela Profa. Dra. Marisa Lajolo. p.370.
} 
mestres - e afinal fui aprender com uma senhora que nem nome tem assina o do marido.

Assim, a partir dessas considerações, daremos continuidade a nossa busca das origens da Hélade construída por Monteiro Lobato. 


\section{Processo(s) de criação de Monteiro Lobato: leituras, diálogos e notas de trabalho}

O processo de criação de Monteiro Lobato era bastante dinâmico. Em algumas oportunidades, valeu-se de seu trabalho como editor, tradutor e revisor para produzir suas obras.

Propomos aqui indicações de suas possíveis fontes da "Grécia”: Will Durant e Virgil Hillyer, autores estadunidenses os quais Lobato traduziu e adaptando-os ao contexto brasileiro.

Destacamos, ainda, a relação epistolar entre o criador de Urupês e o escritor carioca Coelho Neto, considerado um dos responsáveis pela propagação do gosto pelos temas clássicos na literatura brasileira.

\subsection{Monteiro Lobato \& William Durant ${ }^{88}$}

Acreditamos que as obras de William Durant (1885-1981) exerceram importante papel na reconstrução do mundo grego na obra de Monteiro Lobato, principalmente The Life of Greece, obra publicada em 1939 (New York: Simon and Schuster). Lobato traduziu do historiador estadunidense os seguintes títulos: The Story of Civilization. Vol. I: Our Oriental Heritage. New York: Simon and Schuster, 1935; The Story of Philosophy: The Lives and Opinions of the Greater Philosophers. New York: Simon and Schuster, 1926; The Story of Civilization. Vol. II: The Life of Greece. New York: Simon and Schuster, 1939; The Story of Civilization. Vol. III: Caesar and Christ. New York: Simon and Schuster, 1944; Great Men of Literature. New York: Garden City Publishing co. inc., 1936; The Mansions of Philosophy: A Survey of Human Life and Destiny. New York: Simon and Schuster, 1929.

\footnotetext{
${ }^{88}$ O capítulo “Monteiro Lobato \& William Durant” foi desenvolvido durante a iniciação científica e vem sendo ampliado na pesquisa de mestrado.
} 
Muito embora Lobato receba créditos pela versão brasileira de História da Civilização - Nossa Herança Clássica - A Vida na Grécia, a obra não foi traduzida por ele, e sim por sua sobrinha e nora, Gulnara de Morais Lobato. Lobato revisou a tradução e, a partir desta informação, foi possível manter a hipótese de ter sido a obra de Durant uma das fontes lobatianas para a apresentação do mundo grego em seus livros principalmente O Minotauro (1939).

O fato de Lobato recorrer explicitamente a obras alheias para a construção de sua própria obra não surpreende num autor para quem a intertextualidade constitui procedimento recorrente.

Durante parte de sua vida, Monteiro Lobato se dedicou as traduções e “adaptações” de algumas obras como Peter Pan and Wendy (1911) de J. M. Barrie, Child's History of The World (1927) de V. M. Hillyer, a partir das quais produziu Peter Pan (1930) e História Mundo para Crianças (1933).

Nessas “traduções” Lobato adapta essas obras infantis para um contexto essencialmente brasileiro, como observa Edgard Cavalheiro:

Dando um balanço em sua própria produção, [Lobato] acha criminoso não aproveitar onda tão favorável para empreender de uma vez por todas a renovação da literatura infantil no Brasil. Examinando os livros existentes em português, apavora-se com as traduções em curso, e toma a sério refazê-las, abrasileirando-lhes a linguagem. Obras como D. Quixote, Viagens de Guliver, Robinson e outros contos de Andersen, Grimm ou Perrault e tantas outras que circulavam em adaptações ineptas e, o que lhe afigura mais grave, vazadas numa linguagem de difícil entendimento para as crianças brasileiras. Urgia consertá-las. E ao mesmo tempo surgem-lhe novas ideias de histórias originais. $^{89}$

Além dessas “adaptações” mais explícitas, Lobato recorre a informações em livros que traduzia e revisava, como matéria prima de suas obras. Escrevendo a Rangel em 1945, o escritor alude a Will Durant:

Estou com atraso, com 2 cartas tuas sem a resposta pronta do costume. Isso foi porque empreendi a tradução do último volume da História da Civilização do Will Durant, César e Cristo, e apaixonei-me tanto que suspendi todas as minhas atividades, inclusive a epistolar.

Hoje terminei - 700 pags![...]

\footnotetext{
${ }^{89}$ CAVALHEIRO, Edgard. Monteiro Lobato: Vida e obra. São Paulo: Nacional,1955. p. 330.
} 
Essa tradução é a última que faço, e fi-la porque já tinha traduzido os primeiros volumes. Uf!... Chega.

Mas vou ter saudades. Como é bom, como é absorvente, traduzir um bom livro! Vou agora escrever as coisas para a safra deste ano. D. Benta vai com o pessoalzinho para Roma. Vou fazê-los ver a História de Roma”. ${ }^{90}$

Sugerimos que, assim como Lobato afirma ao seu amigo Rangel que usaria o material de sua tradução sobre Roma para escrever mais um de seus livros, tenha feito o mesmo no que diz respeito a sua obra sobre a Grécia, quando revisou a tradução de The Life of Greece.

Com tais pressupostos, organizamos um quadro que, apresentando lado a lado trechos de O Minotauro, de Monteiro Lobato; do original The Life of The Greece, de Will Durant; e de História da Civilização - Nossa Herança Clássica - A Vida na Grécia, a versão nacional da obra de Durant favorece a comparação ${ }^{91}$ :

A

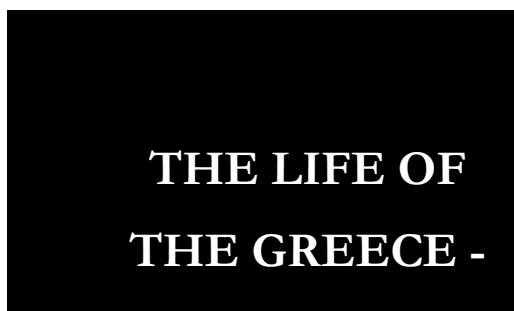

B

\section{HISTÓRIA DA} CIVILIZAÇÃO - NOSSA HERANÇA CLÁSSICA

\section{- A VIDA NA GRÉCIA}

\begin{tabular}{|c|c|c|c|}
\hline 1 & $\begin{array}{l}\text { He seems to have } \\
\text { loved her sincerely, } \\
\text { even uxoriously, } \\
\text { never leaving his }\end{array}$ & $\begin{array}{l}\text { Parece que Péricles a amou } \\
\text { [Aspásia] sincera e } \\
\text { conjugalmente, nunca saindo } \\
\text { de casa ou voltando da rua sem }\end{array}$ & $\begin{array}{l}\text { Nunca vi casal mais } \\
\text { amoroso. Vivem num } \\
\text { idílio eterno. Ele } \\
\text { [Péricles] não é capaz }\end{array}$ \\
\hline
\end{tabular}

\section{O MINOTAURO}




\begin{tabular}{|c|c|c|c|}
\hline & $\begin{array}{l}\text { home or returning to } \\
\text { it without kissing her } \\
\text { [...]. - p. } 253\end{array}$ & beijá-la. - p. 326 & $\begin{array}{l}\text { de entrar ou sair sem } \\
\text { primeiro beijá-la } \\
\text { [Aspásia]. - p. } 190\end{array}$ \\
\hline 2 & $\begin{array}{l}\text { The conservatives } \\
\text { were shocked at all } \\
\text { this, and turned it to } \\
\text { their purposes. [...] } \\
\text { Not daring to bring } \\
\text { any these matters to } \\
\text { open trial, they } \\
\text { attacked him through } \\
\text { his friend. They } \\
\text { indicted Pheidias for } \\
\text { embezzling, as they } \\
\text { alleged, some of the } \\
\text { gold assigned in } \\
\text { convicting him, [...] } \\
\text { they brought against } \\
\text { Aspasia a like writ of } \\
\text { impiety [...] } \\
\text { complaing that she } \\
\text { had shown disrespect } \\
\text { for the gods of } \\
\text { Greece. - p.253-254 }\end{array}$ & $\begin{array}{l}\text { Os conservadores [...] } \\
\text { atacavam-no [Péricles] por } \\
\text { tabela - ferindo seus amigos. } \\
\text { Acusaram Fídias de ter } \\
\text { desviado parte do ouro } \\
\text { destinado à sua creselefantina } \\
\text { [...]; apresentaram contra } \\
\text { Aspásia o mesmo libelo de } \\
\text { impiedade [...], acusando-a de } \\
\text { ter faltado ao respeito dos } \\
\text { deuses da Grécia. - p. } 327\end{array}$ & $\begin{array}{l}\text { Que falam mal dela, } \\
\text { isso sei eu - confessou a } \\
\text { escrava. A política em } \\
\text { Atenas é brava. Péricles } \\
\text { tem muitos amigos - e } \\
\text { também muitos } \\
\text { inimigos que não lhe } \\
\text { perdoam um nadinha. E } \\
\text { quando querem fazer } \\
\text { mal, procuram ferir a } \\
\text { honra de Aspásia. } \\
\text { Sabem que isso lhe dói } \\
\text { porque ele a adora. - p. } \\
190\end{array}$ \\
\hline 3 & $\begin{array}{l}\text { Aspasia became the } \\
\text { uncrowned queen of } \\
\text { Athens, setting } \\
\text { fashion's tone, and } \\
\text { giving to the women } \\
\text { of the city an exciting } \\
\text { exemple of moral } \\
\text { freedom. - p.253 } \\
\text { Aristophanes, an }\end{array}$ & $\begin{array}{l}\text { Aspásia transformou-se na } \\
\text { rainha sem coroa de Atenas, } \\
\text { lançando moda e dando às } \\
\text { mulheres da cidade um } \\
\text { excitante exemplo de liberdade } \\
\text { mental e moral. - p. } 327 \\
\text { Aristófanes, inescrupuloso } \\
\text { inimigo político de Péricles, } \\
\text { descreve-a como uma cortesã }\end{array}$ & $\begin{array}{l}\text { Dona Aspásia, também } \\
\text { se imortalizará como } \\
\text { uma das glórias do sexo } \\
\text { feminino - apresar de } \\
\text { muito difamada. - p. } 190\end{array}$ \\
\hline
\end{tabular}




\begin{tabular}{|c|c|c|c|}
\hline & $\begin{array}{l}\text { unscrupulous } \\
\text { political enemy of } \\
\text { Pericles, describes } \\
\text { her [Aspasia] as a } \\
\text { Milesian courtesan } \\
\text { who had established } \\
\text { a luxurious brothel at } \\
\text { Megara, and had now } \\
\text { imported some of the } \\
\text { girls into Athens [...] } \\
\text { But Aristophanes } \\
\text { was not an historian, } \\
\text { and may be trusted } \\
\text { only where he } \\
\text { himself is not } \\
\text { concerned. - p.252- } \\
253\end{array}$ & $\begin{array}{l}\text { milésia que abrira luxuoso } \\
\text { bordel em Mégara e levara } \\
\text { para Atenas algumas das suas } \\
\text { mulheres [...]. Mas Aristófanes } \\
\text { não era historiador, e nele só } \\
\text { podemos confiar quando as } \\
\text { suas paixões pessoais não } \\
\text { entram em jogo. - p. } 326\end{array}$ & \\
\hline 4 & $\begin{array}{l}\text { He [Pericles] was, so } \\
\text { far as we know, the } \\
\text { most complete man } \\
\text { that Greece } \\
\text { produced. - p. } 248\end{array}$ & $\begin{array}{l}\text { [Péricles] Foi, ao que se } \\
\text { conclui, o homem mais } \\
\text { completo que a Grécia } \\
\text { produziu. - p. } 321\end{array}$ & $\begin{array}{l}\text { Este Senhor Péricles vai } \\
\text { entrar na história como } \\
\text { um dos maiores homens } \\
\text { produzidos pela } \\
\text { humanidade - um gênio } \\
\text { dos mais altos, pela } \\
\text { inteligência, pela } \\
\text { eloquência, pela } \\
\text { sabedoria e pelo amor à } \\
\text { arte [...]. - p. } 190\end{array}$ \\
\hline 5 & $\begin{array}{l}\text { It showed the good } \\
\text { sense of the } \\
\text { Athenians in this } \\
\text { generation that for } \\
\text { almost thirty years, } \\
\text { between } 467 \text { and }\end{array}$ & $\begin{array}{l}\text { O indiscutível bom senso de } \\
\text { uma geração de atenienses } \\
\text { elegeu-o [Péricles] e reelegeu- } \\
\text { o durante quase trinta anos, } \\
\text { entre } 467 \text { e } 428 \text { [...]. Sob sua } \\
\text { política, Atenas, gozando todos }\end{array}$ & $\begin{array}{l}\text { [...] o maior estadista } \\
\text { que governou Atenas } \\
\text { por vontade expressa do } \\
\text { povo. [...] Pois, apesar } \\
\text { de tão longo tempo de } \\
\text { ditadura - mas ditadura }\end{array}$ \\
\hline
\end{tabular}




\begin{tabular}{|c|c|c|c|}
\hline & $\begin{array}{l}\text { 428, they elected and } \\
\text { re-elected him [...]. } \\
\text { Under him Athens, } \\
\text { while enjoying all the } \\
\text { privileges of the } \\
\text { democracy, acquired } \\
\text { also the advantages } \\
\text { of aristocracy and } \\
\text { dictatorship. - p. } 249\end{array}$ & $\begin{array}{l}\text { os privilégios da democracia, } \\
\text { adquiriu também as vantagens } \\
\text { da aristocracia e da ditadura. - } \\
\text { p. } 321\end{array}$ & $\begin{array}{l}\text { à moda grega, } \\
\text { consentida pelo povo, } \\
\text { anualmente renovada } \\
\text { por vontade do povo } \\
{[\ldots] \text { - p.16 }}\end{array}$ \\
\hline 6 & $\begin{array}{l}\text { [Pericles] devoted his } \\
\text { energies now to } \\
\text { beautification of } \\
\text { Athens. Hoping to } \\
\text { make his city the } \\
\text { cultural center of } \\
\text { Hellas, and rebuild } \\
\text { the ancient shrines } \\
\text { [...]. - p.251 }\end{array}$ & $\begin{array}{l}\text { [...] preferiu [Péricles] dedicar- } \\
\text { se com toda energia ao } \\
\text { embelezamento de Atenas. Na } \\
\text { esperança de fazer da sua } \\
\text { cidade o centro da cultura da } \\
\text { Hélade e reconstruir os antigos } \\
\text { templos [...]. - p. } 324\end{array}$ & $\begin{array}{l}\text { E além de ter sido esse } \\
\text { chefe ideal - prosseguiu } \\
\text { Dona Benta, foi o maior } \\
\text { amigo das artes. Graças } \\
\text { a Péricles, Atenas se } \\
\text { transformou numa obra- } \\
\text { prima de arquitetura e } \\
\text { escultura. - p. } 16\end{array}$ \\
\hline 7 & $\begin{array}{l}{[\ldots] \text { in Athens the }} \\
\text { stimulus of growing } \\
\text { wealth and } \\
\text { democratic freedom } \\
\text { was combined with } \\
\text { wise and cuntured } \\
\text { leadership to produce } \\
\text { the Golden Age. - } \\
\text { p.251 }\end{array}$ & $\begin{array}{l}\text { [...] em Atenas o estímulo da } \\
\text { crescente prosperidade e da } \\
\text { liberdade democrática } \\
\text { combinavam-se co um governo } \\
\text { sábio e culto para produzir a } \\
\text { Idade de Ouro. - p. } 323\end{array}$ & $\begin{array}{l}\text { Mas uma coisa estou } \\
\text { sem saber, vovó: a } \\
\text { verdadeira causa desse } \\
\text { povo ter chegado a essa } \\
\text { altura. Deve existir um } \\
\text { segredinho. } \\
\text { - Liberdade, meu filho. } \\
\text { Bom governo. - p. } 16\end{array}$ \\
\hline 8 & $\begin{array}{l}\text { Pericles - others } \\
\text { repects perfectly } \\
\text { formed only his head } \\
\text { was somewhat } \\
\text { longish and out of } \\
\text { proportion; his }\end{array}$ & $\begin{array}{l}\text { Péricles - em outros pontos } \\
\text { perfeitamente conformado, } \\
\text { mas de cabeça } \\
\text { desproporcionada; seus } \\
\text { motejadores muito se } \\
\text { divertiam com essa marcada }\end{array}$ & $\begin{array}{l}\text { Só no físico não foi } \\
\text { perfeito, por falta de } \\
\text { regularidade na forma } \\
\text { do crânio. Péricles tinha } \\
\text { uma cabeça como a do } \\
\text { Totó Cupim, isto é, }\end{array}$ \\
\hline
\end{tabular}




\begin{tabular}{|c|c|c|c|}
\hline & $\begin{array}{l}\text { criticswers to have } \\
\text { much fun with this } \\
\text { very dilicocephalic } \\
\text { head. - p.248 }\end{array}$ & dilicocefalia. - p.320-321 & $\begin{array}{l}\text { como uma bossa de } \\
\text { coruto. - p.13 }\end{array}$ \\
\hline 9 & $\begin{array}{l}\text { He was, so far as we } \\
\text { know, the most } \\
\text { complete man that } \\
\text { Greece produced. - } \\
\text { p.248 }\end{array}$ & $\begin{array}{l}\text { Foi, ao que se concluiu, o } \\
\text { homem mais completo que a } \\
\text { Grécia produziu. - p.319 }\end{array}$ & $\begin{array}{l}\text { [...] e quem a lê [história } \\
\text { de Péricles] admira-se } \\
\text { de encontrar num } \\
\text { mesmo homem tantos e } \\
\text { tão grandes méritos.[...] } \\
\text { era um homem de } \\
\text { grande beleza física, } \\
\text { dessas que se } \\
\text { aproximam da beleza } \\
\text { olímpica. - p.13 } \\
\text { A inteligência de } \\
\text { Péricles pertencia à } \\
\text { classe das verdadeiras, } \\
\text { das que penetram no } \\
\text { fundo das coisas e } \\
\text { compreendem. Por isso } \\
\text { foi o maior homem de } \\
\text { seu tempo, o maior } \\
\text { orador, o maior } \\
\text { estrategista, o maior } \\
\text { estadista que governou } \\
\text { Atenas por vontade } \\
\text { expressa do povo. - } \\
\text { p.15-16 }\end{array}$ \\
\hline 10 & $\begin{array}{l}\text { It showed the good } \\
\text { sense of the } \\
\text { Athenians in this } \\
\text { generation that for } \\
\text { almost thirty years, }\end{array}$ & $\begin{array}{l}\text { O indiscutível bom senso de } \\
\text { uma geração de ateniense } \\
\text { elegeu-o [Péricles] e reelegeu- } \\
\text { o durante quase trinta anos, } \\
\text { entre } 467 \text { e } 428 \text { [a.C.]. [...] Sob }\end{array}$ & $\begin{array}{l}\text { Pois, apesar de tão } \\
\text { longo tempo de ditadura } \\
\text { - mas ditadura a moda } \\
\text { grega, consentida pelo } \\
\text { povo, anualmente }\end{array}$ \\
\hline
\end{tabular}




\begin{tabular}{|c|c|c|c|}
\hline & $\begin{array}{l}\text { between } 467 \text { and } \\
\text { 428, they elected and } \\
\text { re-elected him } \\
\text { [Pericles], [...].Under } \\
\text { him Athens, while } \\
\text { enjoyall the priveges } \\
\text { of democracy, } \\
\text { acquired also the } \\
\text { advantages of } \\
\text { aristocracy and } \\
\text { dictatoriship. - p.249 }\end{array}$ & $\begin{array}{l}\text { sua política, Atenas, gozando } \\
\text { todos os privilégios da } \\
\text { democracia, adquiria também } \\
\text { as vantagens da aristocracia e } \\
\text { ditadura. - p.319 }\end{array}$ & $\begin{array}{l}\text { renovada por vontade } \\
\text { do povo... - p.16. }\end{array}$ \\
\hline 11 & $\begin{array}{l}\text { From } 447 \text { to } 438 \\
\text { Phedias and his aides } \\
\text { were absorbed in } \\
\text { carvins the statues } \\
\text { and reliefs of the } \\
\text { Parteon. [...] He was } \\
\text { the son of the painter, } \\
\text { and for a while under } \\
\text { Polygnotos; [...], it } \\
\text { may be, he acquired } \\
\text { that "groud estyle” } \\
\text { which made him the } \\
\text { greast sculptor in } \\
\text { Greece. - p.324 }\end{array}$ & $\begin{array}{l}\text { De } 447 \text { a } 438 \text { [a.C.] Fídias e } \\
\text { seus auxiliares obsorveram-se } \\
\text { no trabalho das estátuas e } \\
\text { relevos do Partenon. [...] Era } \\
\text { filho de um pintor e durante } \\
\text { algum tempo estudou com } \\
\text { Polignoto; [...] talvez Fídias } \\
\text { tenha haurido de Polignoto } \\
\text { aquele grande estilo “que lhe } \\
\text { granjeou o título de maior } \\
\text { escultor da Grécia”. - p.417- } \\
418\end{array}$ & $\begin{array}{l}\text { - Sim, e graças a } \\
\text { Péricles estou (Fídias) } \\
\text { dirigindo a construção } \\
\text { do templo de Palas- } \\
\text { Atena e de todos os } \\
\text { mais monumentos da } \\
\text { cidade. [...] } \\
\text { - Será possível, meu } \\
\text { Deus? Será possível que } \\
\text { eu [Dona Benta] esteja } \\
\text { diante de Fídias, o } \\
\text { maior escultor de todos } \\
\text { os tempos? } \\
\text { O grego sorriu. - p.27- } \\
28 .\end{array}$ \\
\hline 12 & & $\begin{array}{l}\text { O Partenon, como o Eurecto e } \\
\text { o Teseu, escaparam à } \\
\text { destruição por terem sido } \\
\text { aproveitados como igrejas } \\
\text { cristãs; não foi necessário } \\
\text { grande alteração de nome, }\end{array}$ & $\begin{array}{l}\text { O maravilhoso } \\
\text { Partenão, que o Senhor } \\
\text { Fídias está construindo, } \\
\text { será cruelmente } \\
\text { maltratado. Um dos } \\
\text { vossos sucessores na }\end{array}$ \\
\hline
\end{tabular}




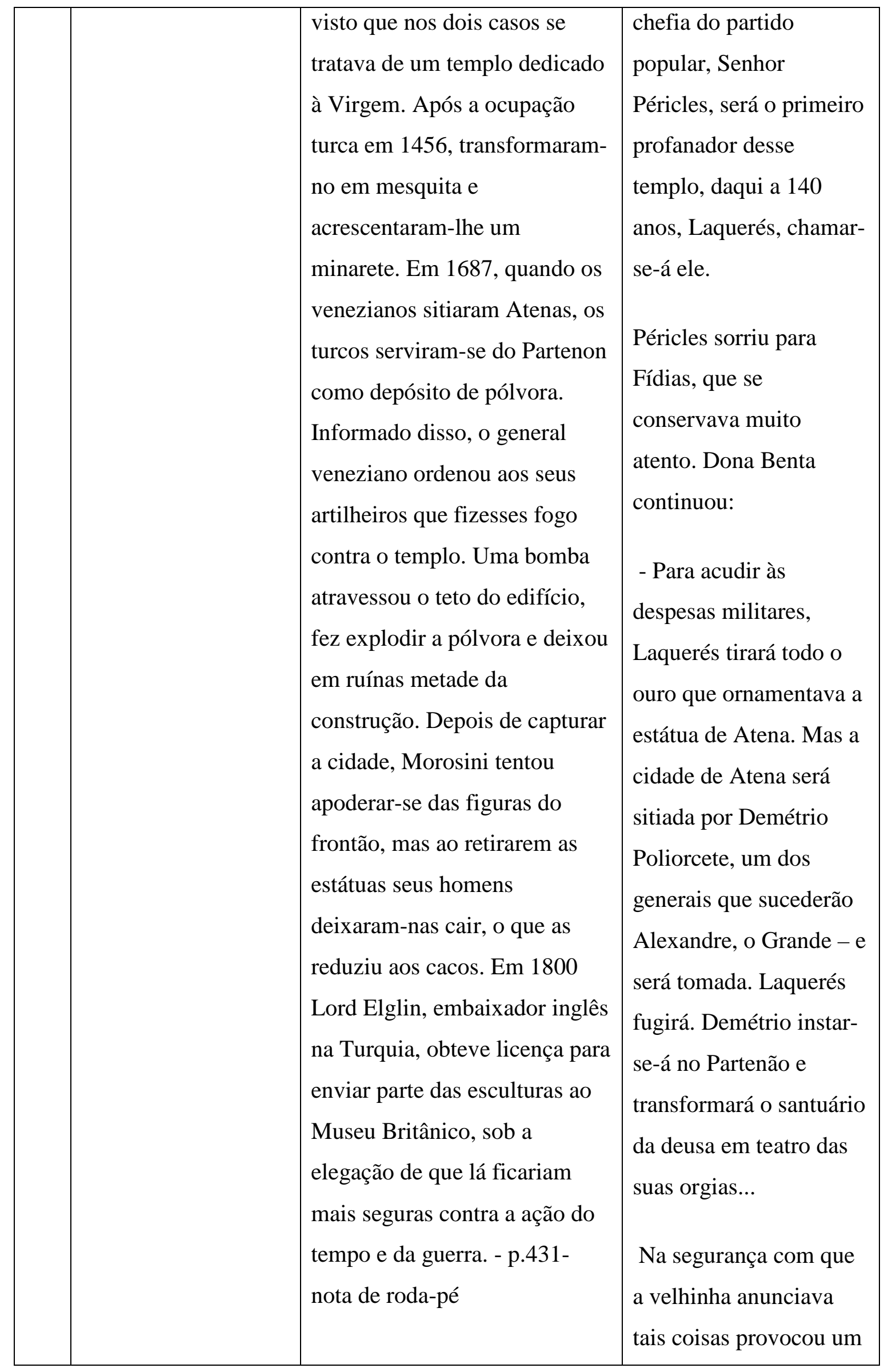




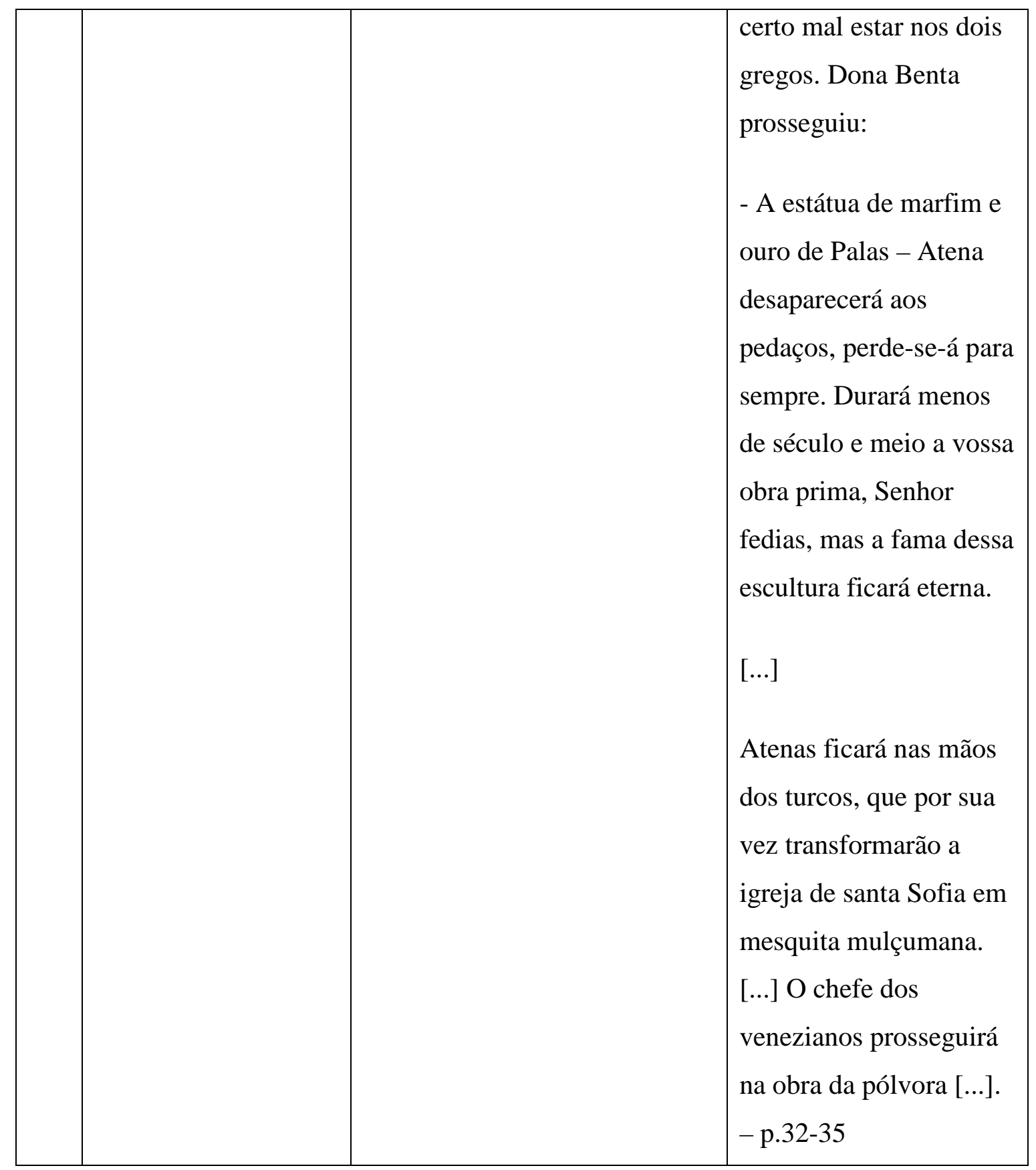

A primeira grande semelhança entre os textos de Lobato e de Durant é que ambos são narrativos, o que não é de se estranhar, já que um pertence a um livro de história e outro a um livro de ficção. No entanto, embora sejam "narrativos”, rompem com a tradição, uma vez que a narrativa histórica tradicional se constrói com maior precisão de datas, recurso a dados e a fontes primárias e, ao tempo de Durant, com uma certa desatenção a temas do cotidiano. Já a ficção permite ao autor uma liberdade maior, 
bem como um menor compromisso com a veracidade, desde que a verossimilhança seja mantida.

Os fragmentos transcritos na linha 6 da tabela são bastante sugestivos para comentarmos alguns procedimentos narrativos adotados pelo historiador: trata-se de um narrador em terceira pessoa que conta a seus leitores e lhes fornece detalhes históricos de fatos que ocorreram no passado:

Péricles [...] preferiu dedicar-se com toda energia ao embelezamento de toda Atenas. Na esperança de fazer da sua cidade o centro de cultura da Hélade e reconstruir os antigos templos - destruídos pelos persas $[. ..]{ }^{92}$

O narrador de Durant parece onisciente ao registrar preferências ("preferiu dedicar-se com toda energia ao embelezamento de Atenas), e expectativas ("fazer da sua cidade o centro da cultura da Hélade e reconstruir os antigos templos”) de Péricles, questões estas, por assim dizer, “de foro íntimo”.

Na passagem equivalente de $O$ Minotauro, na qual o foco também recai sobre a arte em Atenas e o papel que nisso desempenha Péricles, a voz do narrador, agora Dona Benta, não tem papel fundamental. A personagem localiza os leitores em alguns momentos da narrativa; o que prevalece, no entanto, é o discurso direto: ou seja, o narrador “fala” pela boca de Dona Benta:

- E além de ter sido esse chefe de estado ideal [Péricles] - prosseguiu Dona Benta, foi o maior amigo das artes. Graças a Péricles, Atenas se transformou numa obra-prima de arquitetura e escultura. ${ }^{93}$

A técnica narrativa distanciada, em $3^{\mathrm{a}}$ pessoa, não se faz presente na totalidade da obra de Durant. O autor por muitas vezes utiliza o narrador em primeira pessoa do plural:

Depois que, deixando o Atlântico atrás de nós, penetramos a mais bela das águas, surge-nos a arena da história grega. ${ }^{94}$

\footnotetext{
92 DURANT, William. História da Civilização - Nossa Herança Clássica - A vida na Grécia. $1^{\circ}$ Tomo. 3ed. São Paulo; Companhia Editora Nacional,1957, p.324.

${ }^{93}$ LOBATO, Monteiro. O Minotauro 8 ed. São Paulo; Brasiliense, 1952. p. 16.

${ }^{94}$ DURANT, William. História da Civilização - Nossa Herança Clássica - A vida na Grécia. $1^{\circ}$ Tomo. 3ed. São Paulo; Companhia Editora Nacional,1957, p.3.
} 
Percebe-se, também, que Durant, assim como Lobato, romanceia suas histórias; mesmo se tratando de um livro que tem a palavra "história” em seu título, ele narra situações que retratam a vida cotidiana, os sentimentos de "suas personagens", envolvendo os leitores na narrativa.

Além disso, encontram-se igualmente, na obra do historiador, passagens em que ele explicita suas opiniões e preferências:

Aristófanes, inescrupuloso inimigo político de Péricles, descreve-a como uma cortesã milésia que abrira luxuoso bordel em Mégara e levara para Atenas algumas das suas mulheres [...]. Mas Aristófanes não era historiador, e nele só podemos confiar quando as suas paixões pessoais não entram em jogo.

Não deixa de ser curioso Will Durant criticar um escritor pelo emprego de um recurso do qual ele próprio lança mão. O autor também recorre a outros procedimentos retóricos para envolver seus leitores em sua narração.

Por que motivo o segundo grupo das civilizações históricas tomou corpo no Mediterrâneo, do mesmo modo que o primeiro grupo se desenvolveu ao longo dos rios do Egito, da Mesopotâmia e Índia, e o terceiro grupo floresceu no Atlântico - e o quarto começa a aparecer nas costas do Pacífico? Teriam excelência de clima as terras banhadas pelo Mediterrâneo ${ }^{95}$

Como técnica narrativa, do mesmo modo que Lobato, Durant estabelece uma relação do tempo narrado com o tempo da narração, potencializando o diálogo com o leitor. Escreve o historiador norte-americano:

Naquele tempo, como hoje, as chuvas do inverno nutriam o solo, e o frio moderado estimulava o homem; durante quase o ano inteiro uma criatura podia viver ao ar livre, sob um sol bem quente mas de nenhum modo enervante. ${ }^{96}$

No entanto, ao invés de apenas um, a narrativa lobatiana trabalha simultaneamente com dois tempos narrados: a Antiguidade Grega, século XV a.C., (onde vão Pedrinho, Emília e o Visconde, em busca de Tia Nastácia), a Época de Péricles, século V a.C. (onde ficam Dona Benta e Narizinho), e o tempo da narração, a década de 1930.

\footnotetext{
${ }^{95}$ DURANT, William. História da Civilização - Nossa Herança Clássica - A vida na Grécia. $1^{\circ}$ Tomo. 3ed. São Paulo; Companhia Editora Nacional,1957, p.3.

${ }^{96}$ Ibidem. p.3
} 
Deste modo, em O Minotauro, estes três eixos temporais aparecem na narrativa sem divisão alguma; o "problema” da linearidade do tempo é resolvido pelo pó de pirlimpimpim. Por meio desse pozinho mágico, as personagens do Sítio chegam à Grécia e se dividem. Pedrinho, Visconde e Emília vão à Grécia Mitológica e Narizinho e Dona Benta ficam na Grécia de Péricles; com a ajuda do recurso mágico eles podem se comunicar, mesmo estando em épocas diferentes:

Pedrinho apressou os preparativos. Como a Argólia ficasse muito longe iria recorrer à pitadinha do velho pó de pirlimpimpim, o qual servia para locomoção no espaço, Isto é, dum ponto da terra a outro. $\mathrm{O}$ pó número 2, que haviam aspirado no iate, era para a locomoção no tempo, isto é, dum século a outro. ${ }^{97}$

O nosso ilustre Visconde de Sabugosa foi o descobridor de umas ondas sonoras, que receberam o nome de sabuguinas, por meio das quais podemos transmitir mensagens, cantos, músicas, etc., dum século a outro. Neste momento, meu neto Pedrinho, a Emília e o Visconde estão mergulhados no século XV A.C., em plena Grécia Heroica, e de lá enviaram ao receptor uma mensagem, que o Senhor Marquês de Rabicó, lá no iate, apanhou e fixou na cartinha que acaba de vir. ${ }^{98}$

O tempo da narração vem à tona, por exemplo, quando Dona Benta fala às crianças sobre a Grécia de seus dias:

A Grécia de hoje, meus filhos, é um dos pequenos países da Europa, com 116 mil quilômetros quadrados e menos de 5 milhões de habitantes. ${ }^{99}$

Aparece também, de forma mais sutil, quando surgem no texto marcas culturais dos leitores brasileiros do tempo de Lobato, como, por exemplo, quando o néctar dos deuses é comparado com o mel de abelhas e a ambrosia ao curau de milho verde, ou ainda quando Dona Benta compara Palas Atenas a uma padroeira, característica da religião católica incorporada à narrativa:

- Ah, era o que eu pensava! Mel dos Deuses - mas um mel mil vezes mais gostoso que o das abelhas. [...].

Pedrinho provou o néctar e estalou a língua. [...] Vejamos agora a Ambrosia [...].

\footnotetext{
${ }^{97}$ LOBATO, Monteiro. O Minotauro. 8 ed. São Paulo: Brasiliense, 1952, p. 133.

${ }^{98}$ Ibidem. p. 148.

${ }^{99}$ Ibidem. p. 4.
} 
Curau de milho verde, Pedrinho! Curau do bom - mas muito melhor do que o de Tia Nastácia. ${ }^{100}$

Dona Benta parou, estarrecida. Dez majestosas colunas erguiam-se de cada lado, cercando, como sentinelas, a maravilhosa Palas-Atena, a mais rica obra-prima da escultura grega. [...] A padroeira de Atenas lá estava em atitude erecta, na sua túnica... ${ }^{101}$. [grifo nosso]

Dona Benta tem papel fundamental na narrativa. Ela é um tipo de porta-voz do narrador, personagem que traz o conhecimento passado (época mitológica e de Péricles) e presente (anos de 1930), não só para seus netos, mas, sobretudo, para os leitores de Monteiro Lobato. Na biografia do escritor, Edgard Cavalheiro generaliza - para o conjunto da obra lobatiana - esta função exercia por Dona Benta:

Dona Benta é o bom senso, a censura aos velhos métodos, o permanente acicate na inteligência e no espírito crítico dos netos. Sua moda de ler é "diferente". [...] Dona Benta "lia traduzindo". Onde estava, por exemplo, "lume" lia "fogo"; onde estava "lareira", lia "varanda". E sempre que dava com um "botou-o", ou "comeu-o", lia "botou ele", ou "comeu ele", e ficavam, como achavam todos os ouvintes, o "dobro mais interessante".

Pela boca de Dona Benta tudo lhes parecia mais fácil, agradável e pitoresco. Até Geologia, que é coisa muito complicada, aprendem facilmente. E o que dizer de História, Geografia, Gramática e Aritmética, Folclore, Mitologia, Química, Física ou Biologia? Tudo muito simples, despido de mistérios, de impenetrabilidade. [...] Dona Benta [...] troca tudo em miúdos, expõe os fatos e as consequências com absoluta clareza e sempre na ordem direta. ${ }^{102}$

Percebemos a grande importância, em termos de diálogo intertextual, do historiador Will Durant na obra de Lobato, tanto em relação a informações históricas, quanto no emprego de técnicas narrativas.

Reconhecendo a importância de Durant na(s) “Grécia(s) de Lobato”, decidimos buscar mais informações sobre o historiador norte-americano ${ }^{103}$, a fim de entender melhor a relação entre os escritores.

William James Durant (1885-1981) nasceu em North Adams, Massachusetts, estudou em uma escola paroquial católica onde seus professores queriam que ele

\footnotetext{
${ }^{100}$ LOBATO, Monteiro. O Minotauro 8 ed. São Paulo; Brasiliense, 1952, p. 124.

101 Ibidem, p.71.

102 CAVALHEIRO, Edgard. Monteiro Lobato: Vida e obra. São Paulo: Nacional.1955, p.583-584.

${ }^{103}$ As informações sobre a vida e obra de Will Durant foram obtidas no site de sua fundação, e foram por nós traduzidas. Disponível em:< www.willdurant.com> acesso em: 10 fev. 2009.
} 
entrasse para a Ordem Jesuíta, mas em 1903, por meio da Biblioteca pública de Jersey, entrou em contato com obras de Darwin, Huxley, Spencer e Haeckel que o fizeram repensar e mais tarde abandonar sua fé em favor da ciência e da filosofia.

Durant prosseguiu seus estudos e suas leituras nas bibliotecas e, em 1909, começou a interpretar os ensinamentos de Tomás Aquino, com base nas ideias de Karl Marx. Leu também Ethics Geometrically Demonstrated (1677) de Spinoza, obra que o fez conhecer a filosofia e a sociedade de seu tempo.

Em 1911, Durant saiu do seminário e começou a dar aulas na Ferrer Mordern School. Um colaborador da escola, Alden Freeman, proporcionou-lhe uma viagem a Europa. Quando voltou para os Estados Unidos, se casou com uma de suas alunas, Ariel, que se tornou companheira de trabalho e lhe ajudaria a escrever muitos de seus livros.

Estudou ainda na Universidade de Columbia, onde conheceu Morgan e McGregor, Woodbridge e Jonh Dewey.

Em 1917, como requerimento para o doutorado em filosofia escreveu seu primeiro livro Philosophy and the Social Problem (Filosofia e o Problema Social), com o argumento de que a filosofia ignorava os problemas de sua sociedade.

Titulado como Doutor, começou a ensinar na Universidade de Columbia. Com a Primeira Guerra Mundial, perdeu o emprego e começou a dar aulas em uma antiga igreja Presbiteriana em Nova York, que se chamaria depois Labor Temple. Ensinava história da filosofia, literatura, ciência, música e arte.

A maioria de seus alunos eram pessoas que não estavam estudando formalmente, mas tinham interesse pelos temas abordados. Deste modo, Durant desenvolveu um método que valorizava o cotidiano de seus alunos, como meio de apresentar-lhes novos conhecimentos. O sucesso de suas aulas foi tão grande que em 1921, ele organizou a Labor Temple School dedicada à educação de adultos. 
Numa tarde de domingo daquele ano, E. Haldeman-Julius, que publicou os famosos Little Blue Books ${ }^{104}$, decidiu passar na Labor Temple e soube que às 5 da tarde, Durant falaria sobre Platão. O editor entrou e gostou da aula de Durant e o convidou a escrever alguns livros para sua coleção. Durant, inicialmente recusou, por conta de seu outro trabalho, mas Julius insistiu, aumentando a oferta. O professor aceitou a proposta e escreveu 11 livros de bolso, que deram início a sua História da Filosofia.

Com o sucesso dos livros, os editores Dick Simon e Max Schuster, editores de uma nova editora "Simon and Schuster" resolveram publicar os livros de Durant. Eles esperavam vender cerca de 1.100 cópias, sendo mais otimistas, 1.500. Os livros custavam 5 dólares em 1926, para atrair novos leitores. O artigo de Henry Forman no New York Times deu grande notoriedade ao livro que, em poucos anos, vendeu cerca de 2.000.000 de cópias.

Além do sucesso entre os leitores norte-americanos, o livro foi traduzido para o chinês, checo, dinamarquês, holandês, finlandês, alemão, francês, hebraico, húngaro, italiano, japonês, norueguês, polonês, português, servo-croata, espanhol e sueco.

Em carta de 1930, Lobato, morando nos Estados Unidos, escreve a Anísio Teixeira, revelando o entusiasmo ao ler a História da Filosofia de Will Durant:

[Estou] lendo de novo. Passei meses tão absorvido com a Wall Sreet que quase analfabetizei-me. Quem me salvou foi o Will Durant. Fui há dias ao drugstore vizinho comprar uma seringa para Miss Joyce e dei com uma nova edição da História da Filosofia por um dólar. Lembrei-me do que disseste do livro e comprei-o. E fiz mais: li-o, e com regalo e com assombro por não achar ressaibo de sectarismo no expositor. Poucas vezes se terá escrito sobre filósofos e filosofias com encanto de romancista bom, como o fez Durant. E lido Durant pus-me a ler outras coisas e parece que estou curado da obsessão wallstreeteana. ${ }^{105}$

\footnotetext{
${ }^{104}$ Coleção de livros de bolso que contemplava vários assuntos e autores. Sabe-se inclusive que alguns contos de Monteiro Lobato foram publicados nessa coleção.

${ }^{105}$ LOBATO, Monteiro. Carta a Anísio Teixeira, Nova Iorque, 12 abr. 1930. Localização do documento: FGV/CPDOC - Arquivo Anísio Teixeira - ATc 28.06.22.3 Carta publicada no livro Conversa entre amigos: correspondência escolhida entre Anísio Teixeira e Monteiro Lobato. Salvador: Fundação Cultural do Estado da Bahia, Rio de Janeiro: Fundação Getúlio Vargas / CPDOC, 1986. p.51-53. Disponível em: $<$ http://www.bvanisioteixeira.ufba.br/cartas/lobato2.html > Acesso em: 24 jun. 2009.
} 
A primeira tradução brasileira de Story of Philosophy foi assinada por Monteiro Lobato e Godofredo Rangel. Em 6 de junho de 1934, Lobato propõe ao amigo dividir a tarefa:

Dividamos ao meio a Story of Philosophy do Will Durant e assinemos com iniciais os capítulos que o traduzirmos. Juntos até na história da filosofia... Minha ideia é fazer um trabalho perfeito. O Octales ${ }^{106}$ não tem muita pressa. Durant merece todo carinho e nós temos responsabilidades ${ }^{107}$.

Lobato, por ocasião da segunda edição de Filosofia da Vida expressa o interesse renovado pela obra, ao escrever ao amigo:

Eu apodreço no ferro, onde também só encontramos obstáculos (já estou no ferro há 10 anos!) E você apodrece nas traduções. Por falar: leia a Filosofia da Vida do Will Durant a maravilha das maravilhas. Mas leia a 2a edição, ainda no prelo. As segundas edições de coisas minhas são sempre melhores que as primeiras. Revi ontem as últimas provas. Maravilha, Rangel. ${ }^{108}$

A relação entre Will Durant e Lobato pode ser confirmada ainda pela presença de carta de 31 de dezembro de 1937, na qual o escritor norte-americano agradece ao tradutor de Mansions of Philisophy:

I have received today the translation of my Mansions of philosophy into Portuguese. I am happy to learn that I am to have the opportunity of making new friends in Brazil $[\ldots]^{109}$

O vínculo amigável de Durant não apenas com Lobato, como também com os brasileiros pode ser percebida no prefácio que o historiador faz para a tradução brasileira Great Men of Literature (Os Grandes Pensadores ${ }^{110}$ ), em 1939. Nele o escritor americano discute o que considera "as grandes ideias" da humanidade, explicita a vontade de conhecer o Brasil e sua "semelhanças” (sintonia) com os latinos ${ }^{111}$.

O título de Will Durant como historiador em seus livros pode ser contestado, devido ao tipo de "História” que ele fez. Talvez por sua formação filosófica ou por sua

\footnotetext{
${ }^{106}$ Editor da Companhia Editora Nacional.

${ }^{107}$ LOBATO, Monteiro. A Barca de Gleyre: Quarenta anos de correspondência literária. 8. ed. São Paulo: Cia Editora Nacional, 1957. p.365-366. Carta de São Paulo, 6 jun. 1934.

108 LOBATO, Monteiro. A Barca de Gleyre: Quarenta anos de correspondência literária. São Paulo: Cia Editora Nacional, 1944, Carta de São Paulo, 1 jun. 1938.

${ }^{109}$ CEDAE/IEL/UNICAMP , código MLb 3.2.00397cx8.

110 Tradução de Monteiro Lobato.

${ }^{111}$ V. em Anexo o Prefácio para edição brasileira de Os Grandes Pensadores.
} 
experiência como professor, Durant sempre propôs uma "história humanizada". Escrevia às pessoas simples que não estavam no ambiente universitário; como explica no Prefácio ${ }^{112}$ da $2^{\mathrm{a}}$ edição americana da História da Filosofia:

Não nos envergonhamos de ensinar ao povo. Os ciosos que querem evitar que o grande público se aproveite dos seus conhecimentos e para isso escondem a ideia na maranha da terminologia bárbara, impedem o público ansioso de saber para todas as fontes claras. Não se abespinhem esses homens contra obras como a nossa, que vem em socorro do público e para lhe facilitar a tarefa humanizam a filosofia. ${ }^{113}$

O prefácio foi escrito em resposta às críticas que o livro recebeu dos “especialistas”, a principal delas era a incompletude em sua "História” e a omissão de importantes filósofos, como, por exemplo, os da filosofia escolástica. Como resposta a essas críticas e explicação quanto ao objetivo de sua obra Durant escreve:

Muitas dessas críticas eram desagradavelmente justas. A História da Filosofia está cheia de defeitos. O maior de todos reside em ser incompleta. A omissão total da filosofia escolástica unicamente perdoável para os que lhe padeceram o martírio nos seminários e ficaram desconfiados de que era apenas teologia disfarçada e de nenhum modo filosofia. É verdade que em alguns casos (Schopenhauer, Nietzsche, Spencer,Voltaire) a exposição da doutrina foi mais completa do que a maioria das histórias da filosofia. E é também verdade que já no início se declara francamente:

Este livro não é uma história completa de filosofia. É uma tentativa para humanizar conhecimentos concentrando a história do pensamento especulativo em redor de algumas personalidades dominantes. Figuras menores foram omitidas para que as maiores tivessem suficiente espaço. [Prefácio]. ${ }^{114}$

O trecho acima nos mostra que Durant "selecionava” o que escrevia em seus livros. O autor direcionava o leitor, quando apresentava a eles correntes filosóficas, ou autores que lhe pareciam mais relevantes; e também dava mais importância a alguns fatos que a outros; além de tomar posição perante aos fatos e de romancear a história, como acontece em The Life of The Greece, quando o autor toma partido de Péricles e, com ele, Lobato, em O Minotauro.

\footnotetext{
112 Prefácio encontrado na tradução de Lobato, p.13.

113 DURANT, William. História da Filosofia. São Paulo: Cia Editora Nacional, s/d, p.13.

${ }^{114}$ DURANT, William. História da Filosofia. São Paulo: Cia Editora Nacional, s/d.p.10.
} 
Durant não considerava suas obras como um “manual completo” de filosofia ou história, mas sim como porta de entrada para a população ter acesso aos clássicos. No mesmo prefácio, Durant manifesta a alegria de saber que depois da publicação de seu livro, a venda dos clássicos da filosofia cresceu em duzentos por cento:

É animador saber que depois da publicação desta Historia da Filosofia a venda das obras clássicas aumentos duzentos por cento. Muitos editores tiveram que reeditá-las, particularmente as de Platão, Spinoza,Voltaire, Schopenhauer e Nietzeche. ${ }^{115}$

Lobato também teve papel fundamental na popularização do conhecimento e da leitura, principalmente em relação ao público infanto-juvenil. Como editor, criou novas capas e formas para os livros brasileiros, publicou autores desconhecidos e fez os livros chegar a praticamente todo o Brasil. Afirma Lobato:

"Dizem que o Brasil não Lê! Uma ova! A questão é saber levar a edição até o nariz do leitor, aqui, ou em Mato Grosso, no Rio Grande do Sul, no Acre, na Paraíba, onde quer que ele esteja sequioso por leituras... Livro cheirado é livro comprado, e quem compra lê. Se o Brasil não lia é porque os velhos editores, na maior parte da santa terrinha, limitavam-se a arrumar os volumes nas poeirentas prateleiras das suas próprias livrarias, e quem quiser que tome o trem, ou o navio, e vá ao Rio comprá-los. Umas bestas! O Brasil está louco por leituras. Só os editores não sabiam disso!...”116

Lobato traduziu obras de literatura adulta, como as obras de Durant, e de literatura infantil. Assim como o norte-americano, o escritor brasileiro acredita que a obra deve ser compreensível ao seu leitor, e muitas vezes adapta suas traduções, o que lhe rendeu muitas críticas. Sobre seu “método” de tradução, ele afirma:

O tradutor necessita compreender a fundo a obra e o autor, e reescrevê-la em português como quem ouve uma história e depois conta com palavras suas. Ora isto exige que o tradutor seja também escritor - e escritor decente. ${ }^{117}$

Percebemos que ambos os escritores tentaram "adaptar" ou "facilitar" um conhecimento dito culto, ou erudito para seus leitores. No caso de Durant, eram predominantemente adultos sem grau elevado de leitura; e, no caso de Lobato, principalmente crianças em formação.

\footnotetext{
${ }^{115}$.Ibidem. p.12-13.

${ }^{116}$ Apud: CAVALHEIRO, Edgard. Monteiro Lobato: vida e obra. São Paulo: Nacional, 1955, p.242.

${ }^{117}$ Ibidem. p 537.
} 


\subsection{Monteiro Lobato \& Virgil Mores Hillyer ${ }^{118}$}

“Alea jacta est! - que significa - A sorte está lançada!”"119

Ainda na busca pelas fontes gregas de Lobato, nos deparamos com o educador Virgil Mores Hillyer (1875-1931), autor de A Child's History of the World (1924), obra que deu origem a História do Mundo para Crianças de Monteiro Lobato (1933) - livro infantil repleto de passagens sobre a antiguidade clássica.

Em História do Mundo para as Crianças, Dona Benta, avó bem informada, apresenta o livro de Hillyer à meninada do Sítio. Além de possuir uma grande biblioteca, a senhorinha sempre sabia das novidades do mundo editorial, como Child's History of World:

Dona Benta era uma senhora de muita leitura; além de ter uma biblioteca de várias centenas de volumes, ainda recebia, dum livreiro da capital, as novidades mais interessantes do momento.

Uma tarde o correio trouxe-lhe a Child's History of World, de V. M. Hillyer, diretor da Calvet School, de Baltimore. ${ }^{120}$

Depois de ler o livro, com “cara de quem estava gostando”, e folhear vários volumes de sua biblioteca, decidiu que a história do mundo devia sim ser assunto de criança. A partir daí começou a ler à sua maneira a "história universal”, iniciando pelo big bang, passando pelos homens das cavernas, Grécia, Índia, Roma, Idade Média e chegando a fatos ocorridos no início do século XX.

Encontramos no acervo que pertenceu ao escritor, na Biblioteca Infantil Monteiro Lobato, em São Paulo, exemplar de Child’s History of World, no qual há duas indicações de datas na terceira capa: “7/1/33” e “4/3/33”, as quais podem sugerir o período de leitura da obra estrangeira.

\footnotetext{
${ }^{118}$ Este capítulo foi desenvolvido em pareceria com Camila Russo de Almeida Spagnoli e apresentado parcialmente como comunicação sob o título "Livros, leituras e outros livros: um certo Monteiro Lobato leitor” no $2^{\circ}$ CIELLI - Colóquio Internacional de Estudos Linguísticos e Literários, realizado na Universidade Estadual de Maringá - PR.

${ }^{119}$ LOBATO, Monteiro. História do mundo para as crianças. 3 ed. São Paulo: Brasiliense, 1952 . p. 113.

${ }^{120}$ LOBATO, Monteiro. História do Mundo para as Crianças. 3 ed. São Paulo: Brasiliense, 1952. p. 3.
} 


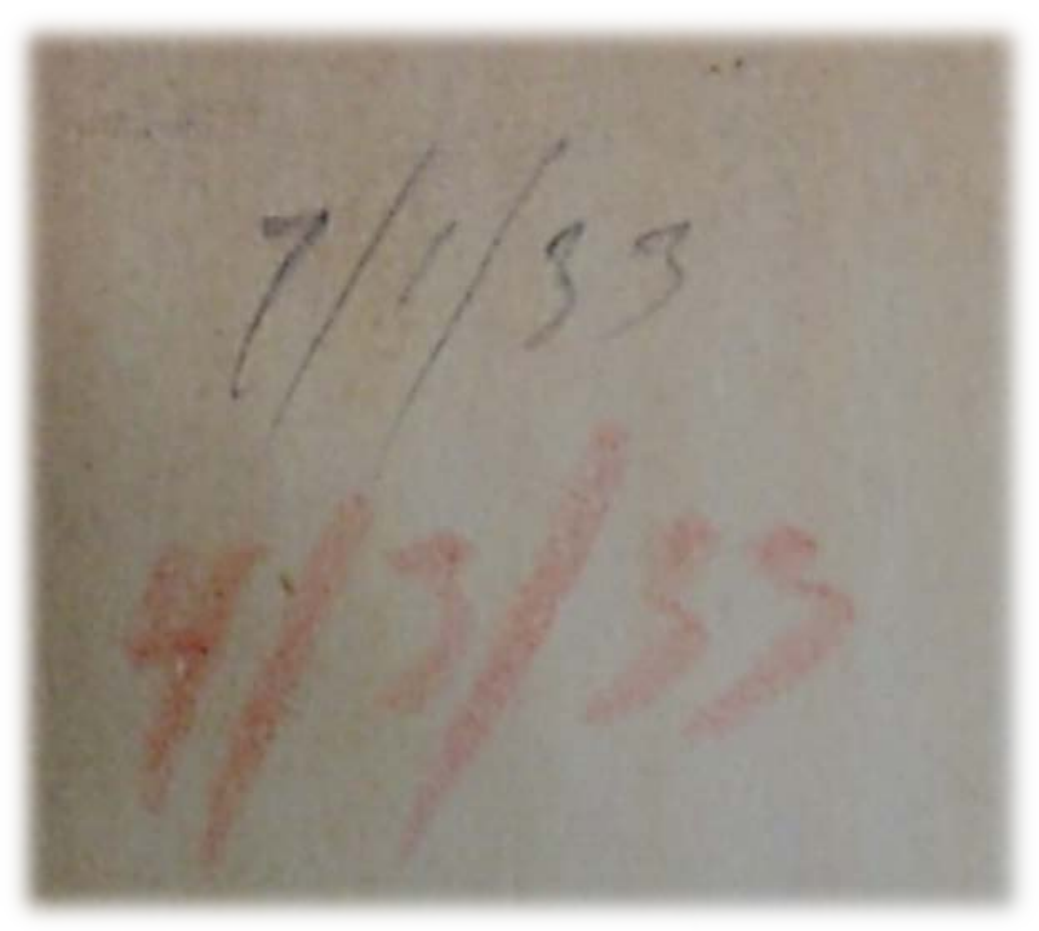

Anotação das datas “7/1/33” e “4/3/33” a grafite e lápis azul

(Biblioteca Infantil Monteiro Lobato, São Paulo)

É curioso que a primeira edição de História do mundo para crianças é de 1933, data também mencionada em nota manuscrita no exemplar de Child's History of World que pertenceu a Monteiro Lobato.

Ao que parece, Lobato lia e já tratava de transformar sua leitura em um novo produto para o público brasileiro. Tal hipótese se dá porque no exemplar, pertencente a sua biblioteca pessoal, há anotações marginais e trechos recortados que deixam marcas de uma nova produção.

Observaremos aqui algumas intervenções no exemplar feitas por Lobato, em trechos que tematizam a Grécia.

Na ilustração do Partenon presente na obra americana, observar-se a nota “+ feita” e um quadriculado na imagem, o que sugere que a imagem foi copiada com suas proporções mantidas. Imagem semelhante também é encontrada na versão brasileira ${ }^{121}$.

\footnotetext{
121 As imagens de História do Mundo para Crianças foram reproduzidas a partir da edição de Obras Completas de 1952.
} 


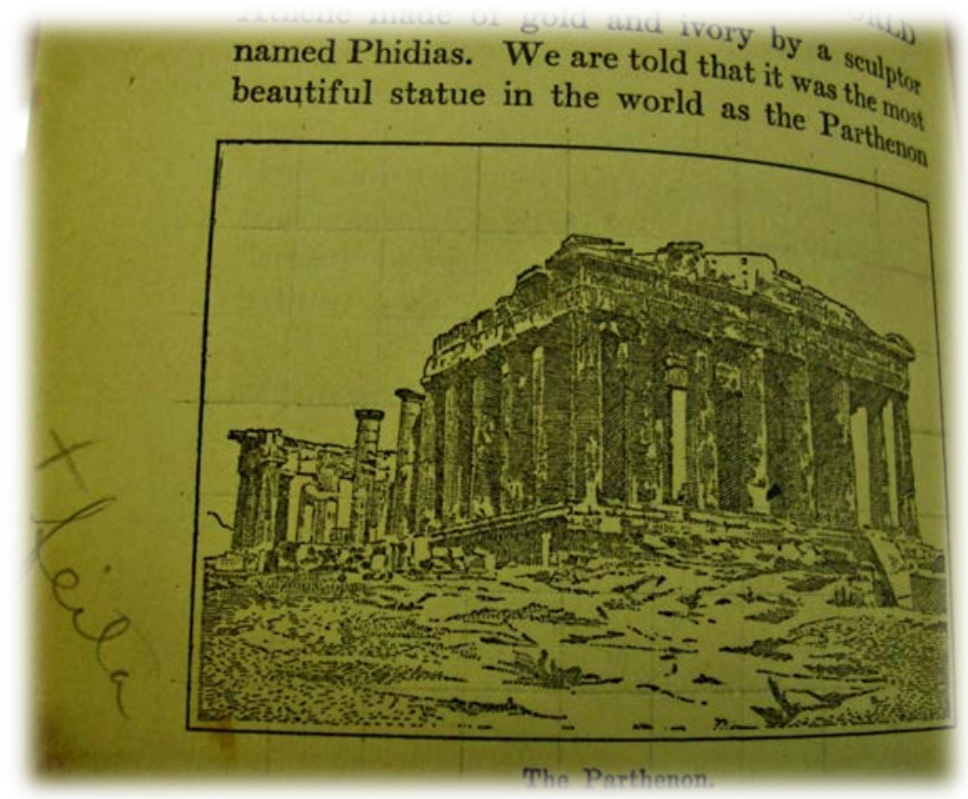

Imagem quadriculada e trecho destacado por anotação a grafite na leitura de Lobato (Biblioteca Infantil Monteiro Lobato, São Paulo)

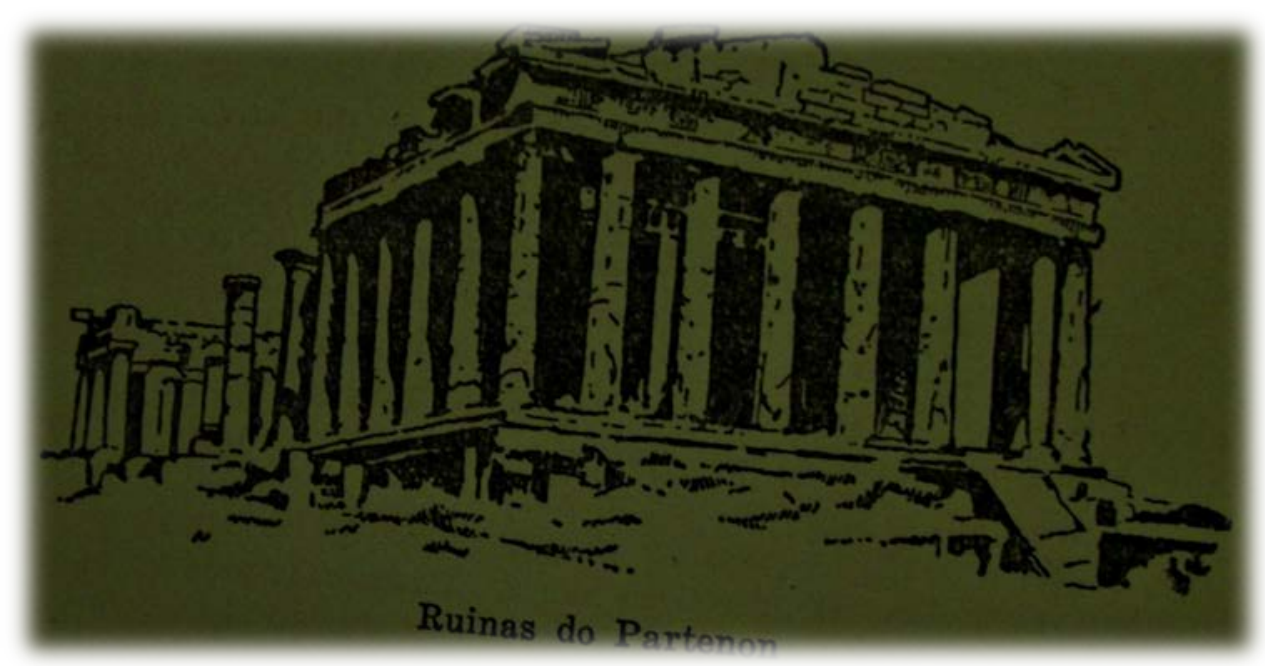

Ilustração presente em História do Mundo para Crianças

Ainda sobre a arquitetura grega - assunto que muito interessava Monteiro Lobato - o escritor destacou a imagem de três tipos de colunas: dórica, jônica e coríntia, as quais também foram representadas em sua obra. 


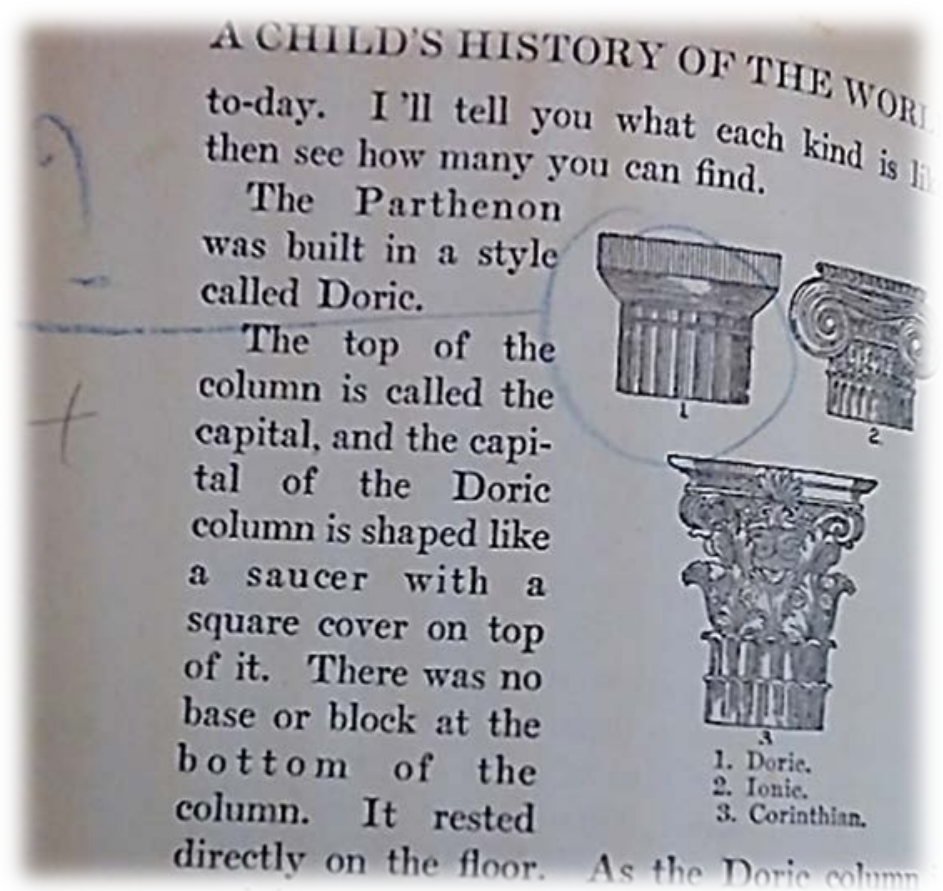

Trecho destacado por anotação a grafite azul na leitura de Lobato (Biblioteca Infantil Monteiro Lobato, São Paulo)
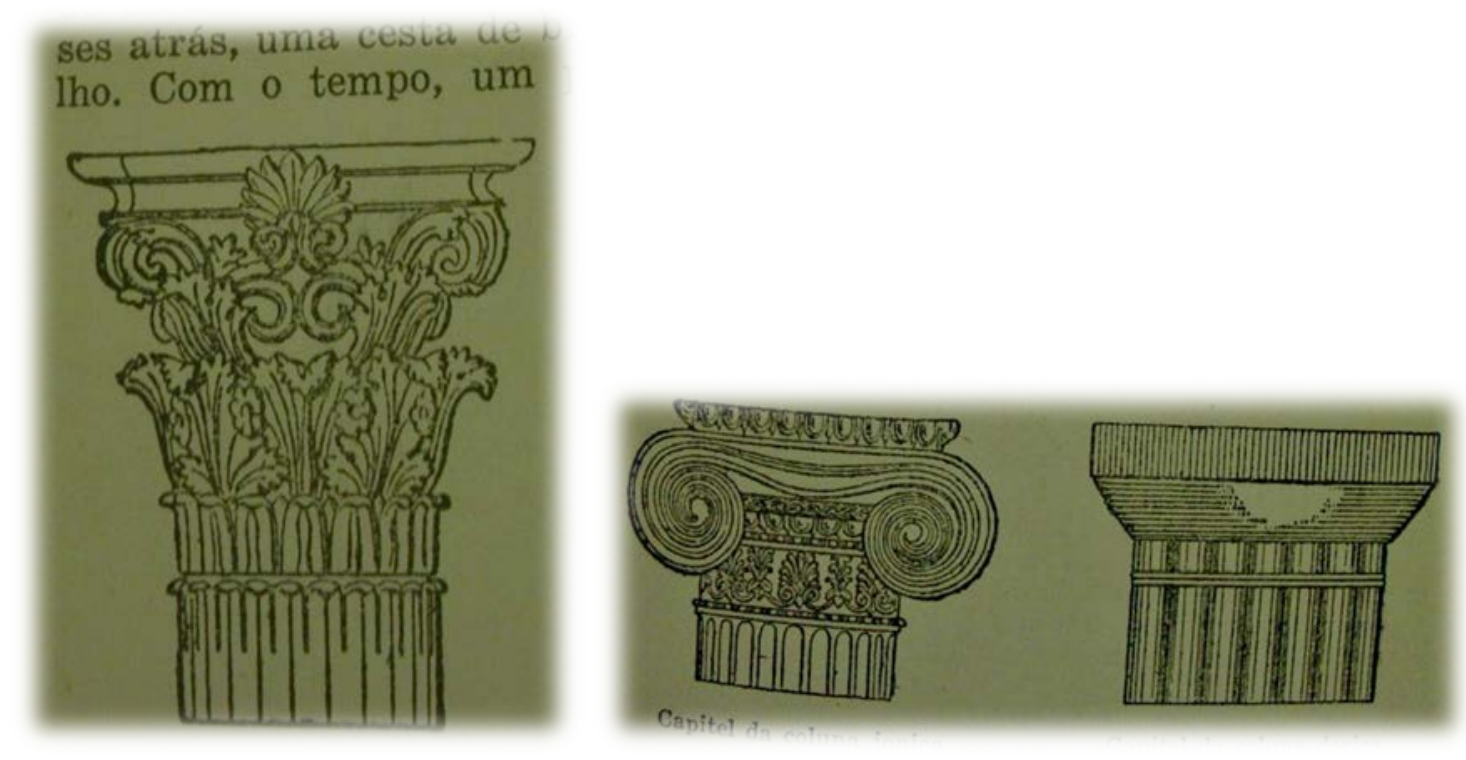

Reprodução da imagem em História do mundo para as crianças

Se as anotações marginais do escritor nos apontam decisões sobre as imagens que apareceriam em sua obra, também nos indicam possíveis desistências quanto à utilização delas. Na imagem abaixo sobre o nascimento da deusa Minerva, percebe-se a marcação “+” (cruzeta) que posteriormente foi rasurada. É importante destacar que tal imagem não aparece na versão brasileira. 


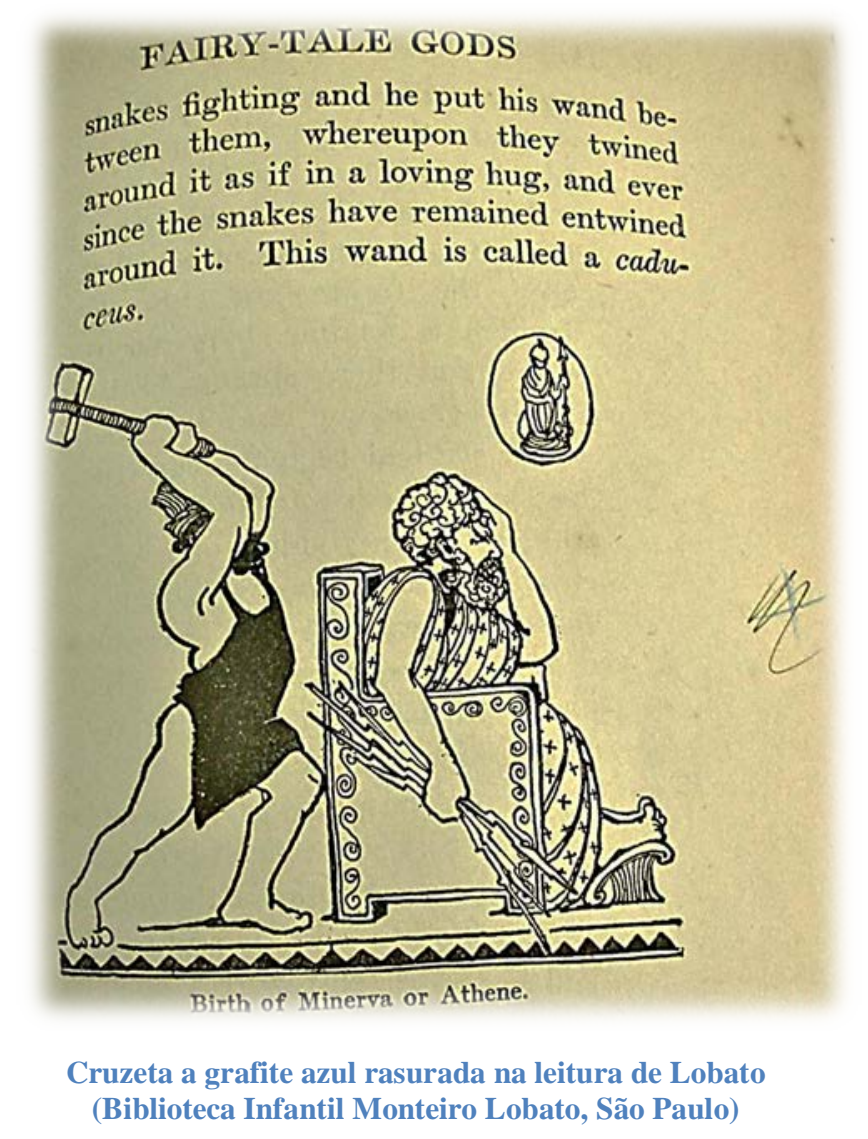

Outra interferência do autor de Urupês feito na obra americana é o recorte do que seria o nome de Nabucodonosor. A forma das letras parece chamar tanto a atenção do autor, que no enredo de sua História é Pedrinho quem “copia os garranchinhos” dos caracteres cuneiformes.

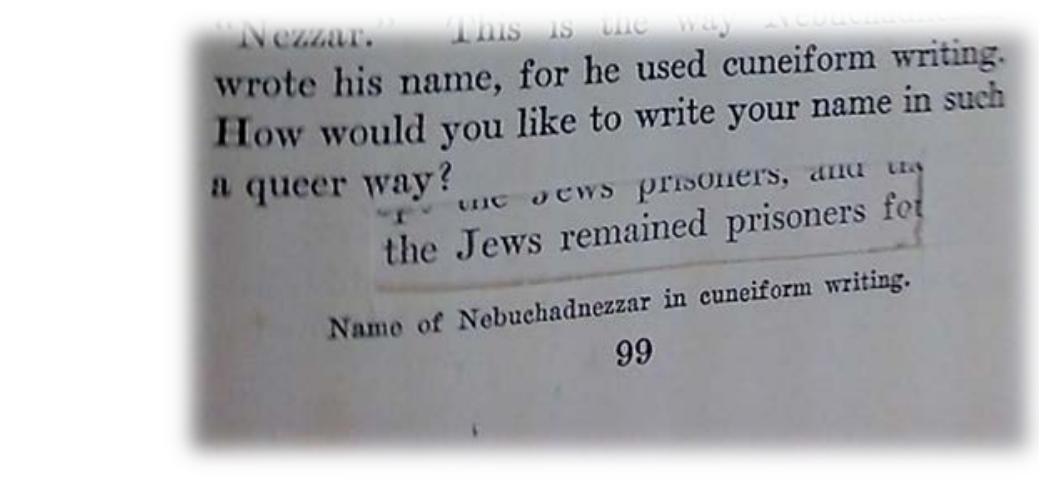

Lobato extrai de A child's history of the world o fragmento que lhe interessa no texto (Biblioteca Infantil Monteiro Lobato, São Paulo) 


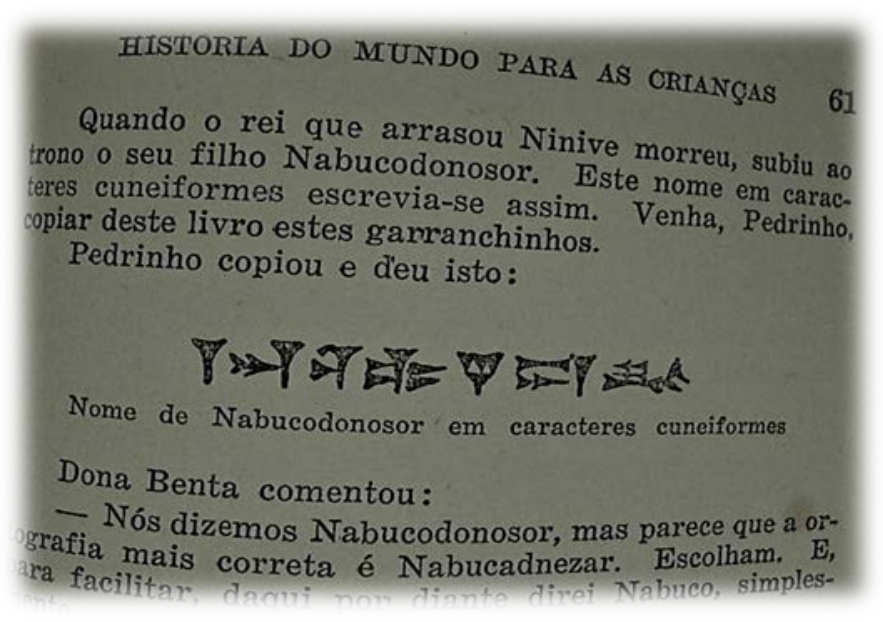

Imagem reproduzida em História do Mundo para Crianças

Mas se por um lado Lobato se apropria do material da leitura de Hyller, por outro acrescenta episódios da história considerados por ele importantes. Míriam Pallota compara algumas edições do livro e comenta:

A edição de 1943 [de História do Mundo para Crianças] foi acrescida de dois novos capítulos: um deles apresenta alguns dados sobre a formação étnica, política e linguística da Península Ibérica (Capítulo LXVII - A Península Ibérica) e o outro enfoca a atuação de Simón Bolívar no processo de independência de alguns países da América Latina (Capítulo LXXIX - O Libertador). [...]

Na $11^{\text {a }}$ edição, foram acrescentados, dois novos capítulos, os últimos da obra: o LXXX - A Segunda Guerra Mundial, e o LXXXI, Hiroshima $^{122}$.

Assim, o trabalho iniciado por Dona Benta de contar a "história do mundo" a partir da leitura de Hyller e dos outros livros de história de sua biblioteca, em certa medida e em outro nível de análise, é continuado por Lobato, de modo que não apenas traduz a obra norte-americana, mas a atualiza e comenta segundo a realidade brasileira e latinoamericana, (re) criando uma nova história.

Esses são alguns dos exemplos das marcas deixadas pelo escritor paulista de seu processo de criação de História do Mundo para Crianças, no entanto, sabe-se que processo semelhante ocorre em outras obras do escritor.

\footnotetext{
${ }^{122}$ PALLOTTA, Míriam Giberti Páttaro. "História do mundo para as crianças: uma obra inovadora”. In: LAJOLO, Marisa; CECCANTINI, João Luís. (Org.). Monteiro Lobato, livro a livro. 1 ed. São Paulo: UNESP e Imprensa Oficial, 2008. p. 222-223.
} 
Observando o processo de leitura/escrita de Monteiro Lobato na obra A Child's History of the World, decidimos buscar mais informações sobre Hillyer para entender melhor esse "diálogo” entre os autores.

Virgil Mores Hillyer nasceu em 2 de setembro de 1875 em Weymouth, graduouse em Harvard em 1827 em Educação. Foi professor da Calvert School e tornou-se seu diretor em 1899, onde trabalhou até o ano de sua morte, $1931^{123}$.

A história desse norte-americano se confunde com a da escola onde dedicou boa parte da vida e muitos de seus textos foram escritos como material de apoio para suas aulas. Para o ensino das aulas de História, desenvolveu o método em que valorizava o aspecto narrativo dos fatos históricos, chegando a desaconselhar o uso de livros didáticos nas séries iniciais, sendo o professor o responsável por comunicar oralmente os assuntos para as crianças, como forma de aproximá-las.

A produção de A Child's History of the World surge alinhada a essa proposta pedagógica, como tentativa a auxiliar as crianças que não frequentavam a escola e estudavam no regime de ensino domiciliar. Assim, Hillyer criou um material com fortes marcas de oralidade para "simular" o diálogo do professor em sala de aula. Ainda sobre essa técnica didática acrescenta Míriam Palotta:

Ele consegue aliar discurso científico com discurso literário, resultando numa obra que media ficção e realidade, ou ainda que, apesar de centralizada nos fatos históricos, não despreza fatos ficcionais que servem de estímulo para a compreensão e memorização dos primeiros ${ }^{124}$.

No trecho abaixo, o narrador apresenta a Grécia a seus leitores e explica a expansão dos helenos no mapa, contando como uma vez ele deixou cair tinta na mesa e essa se espalhou rápido, o que facilitaria a compreensão das crianças:

There was once a man named Hellen - strange-sounding name for a man, is n’t it? He was not a Semite and not Hamite. He was an Aryan.

\footnotetext{
123 Como principais fontes sobre a vida e obra de Virgil M. Hillyer temos as informações do site da Calvert School, (Disponível em: <http://homeschool.calvertschool.org/section-test/7/265-hillyersvision>. Acesso em: 01 ago. 2012) e o texto: PALLOTA, Míriam Giberti Páttaro Pallota. Uma história ao contrário: um estudo sobre História do Mundo para as Crianças de Monteiro Lobato. Assis: UNESP, Faculdade de Ciências e Letras, 2001. (Tese de Doutorado).

${ }^{124}$ PALLOTA, Míriam Giberti Páttaro Pallota. Uma história ao contrário: um estudo sobre História do Mundo para as Crianças de Monteiro Lobato. Assis: UNESP, Faculdade de Ciências e Letras, 2001. (Tese de Doutorado). p.27.
} 
He had a great many children and children's, and they called themselves Hellenes. They lived in a little scrap of a country that juts out into the Mediterranean Sea, and they called their land Hellas. I once upset a bottle of ink on my desk, and the ink ran out into a wriggly spot that looked exactly as Hellas does on the map. Though Hellas is hardly any bigger than one of our States, its history is more famous than that of any other country of its size in the word. We call Hellas "Greece" and the people who lived there "Greeks"125. [grifo nosso]

Além da preocupação em aproximar o narrador do leitor, o escritor escolhia tipos e palavras e estruturas narrativas, as quais julgava mais apropriadas aos pequenos, como, por exemplo, a escolha de títulos extravagantes, o uso de frases curtas, etc. No texto Calvert and Hillyer, A. Hart transcreve algumas sugestões de redação destinada ao público infantil:

Faça as palavras escritas brilharem como num luminoso. Palavras gritam. Organize o tipo falar. Extravagante, doida, excêntrica, exclamações incomuns em inglês: Bubble and Squeak! Jerusalem Cricjet! Gee Hosaphat! Wollop Crollop! Jiggerywhiggery! Cricky! E Snoozes! no mapa..."

Evite expressões como "Pelos idos do ano 300... Se você olhar

Frases curtas o tempo todo. Frases acumulativas e repetitivas. Exclamações. Perguntas curtas. Comparações com os dias de hoje. Frases de duas palavras. Use como e tal qual frequentemente. Comece cada lição e cada parágrafo com uma frase significativa. Sempre use a voz ativa, nunca a voz passiva. Faça animadamente o início de cada capítulo. Faça brotar a curiosidade. Não diga o final na primeira frase. Para cada capítulo faça finais característicos e alegres ${ }^{126}$.

A escolha de títulos chamativos como "Fairy-tale gods" (Conto de Fadas dos deuses) que usa para apresentar o capítulo sobre a Grécia é estratégia de que recorreu Hyller.

A discussão sobre títulos também é tema de Monteiro Lobato, que já pela boca de seus personagens anunciam o assunto do próximo livro e sugerem títulos para ele:

- Que lindo livro vai ser! - exclamou Emília. VIAGEM DO SÍTIO PELO OCEANO DA IMAGINAÇÃO GREGA.

\footnotetext{
${ }^{125}$ HILLYER, V.M. Child's History of The World. New York: Century, s/d. p.56.

${ }^{126}$ PALLOTA, Míriam Giberti Páttaro Pallota. Uma história ao contrário: um estudo sobre História do Mundo para as Crianças de Monteiro Lobato. Assis: UNESP, Faculdade de Ciências e Letras, 2001. (Tese de Doutorado). p.31-32.
} 
- Comprido demais, Emília. Os títulos devem ser curtos, se não ninguém decora. Veja: OS LUSÍADAS, A ILÍADA, A ODISSEIA, O INFERNO, A ENEIDA..."127

Assim, percebemos frequente a preocupação dos escritores com seu público. Os dois prezavam pela opinião de seus leitores, e valorizavam suas sugestões na produção de seus livros. Sobre a participação dos leitores no processo de criação de Hillyer, Míriam comenta:

[Enquanto Hillyer escrevia,] ouviu a opinião de todos os alunos de 11 anos da Calvert School, os quais votaram a favor ou contra de cada história que, na verdade, era uma parábola. Este desejo em saber a opinião dos alunos e o cuidado em finalizar suas obras a partir deste feedback ocorria desde 1922. Assim, os manuscritos de $A$ Child's History of the World, A Child's Geograph of the World e A Child's History of Art também foram lidos para os alunos do próprio Hillyer, para que pudessem avaliá-los e julgá-los ${ }^{128}$.

Semelhante participação dos leitores também pode ser notada por meio de cartas que remetiam a Lobato. A menina Sarah, por exemplo, lhe escreveu pedindo um livro sobre a História do Brasil. Ela conta ao escritor que já existiam na época outros volumes sobre o assunto, mas que não eram muito apreciados pelos leitores como ela:

Estou estudando a História do Brasil e como acho muito cacete, peço por favor que o senhor escreva, um livro sobre este assunto.

Acho que o senhor não quer escrever porque o Viriato Corrêa ${ }^{129}$ plagiou seus contos, escrevendo logo a História do Brasil.

Mas por mim pode escrever porque certamente já o tinha imaginado e mesmo eu não gosto dos livros que o Viriato Corrêa faz. Prefiro os seus. muito. ${ }^{130}$

Já li quase todos os seus livros achando muita graça e gostando

Outro leitor, Sylvio, escreve a Lobato pedindo que ele escreva um livro que trate de Ciências, pois apesar de gostar muito do assunto, o menino não consegue decorar os nomes dos músculos e tecidos, mas acredita que com um “livro da Emília” é possível aprender tudo:

\footnotetext{
${ }^{127}$ LOBATO, Monteiro. O Picapau Amarelo. 7 ed. São Paulo: Brasiliense,1957, p. 135-136.

${ }^{128}$ PALLOTA, Míriam Giberti Páttaro Pallota. Uma história ao contrário: um estudo sobre História do Mundo para as Crianças de Monteiro Lobato. Assis: UNESP, Faculdade de Ciências e Letras, 2001. (Tese de Doutorado). p.39.

${ }^{129}$ Escritor de livros infantis contemporâneo a Lobato.

${ }^{130}$ Carta de Sarah Viegas da Motta Lima. IEB/ ARAS.Cx.1 p2 doc23.
} 
Envio-lhe esta, para pedir que escreva um livro tratando de ciências incluindo nele a Emília e o Visconde, Narizinho, Pedrinho, tia Nastácia, D. Benta.

Estou no terceiro ano ginasial e gosto muito desta matéria.

Aí ocorreu-me a ideia de lhe escrever, porque com seus livros, aprende-se brincando!

É duro decorar aqueles nomes de músculos, tecidos, etc.

Mas com um livro "da Emília”, quem não aprende?

Por exemplo, fiquei maravilhado ao ler História do mundo para crianças", "Geografia da D. Benta”, "Emília no país da gramática”, "Aritmética da Emília” e outros. ${ }^{131}$

Outro recurso frequentemente usado - tanto por Monteiro Lobato quanto por Virgil Hillyer - é a associação entre conhecimentos específicos como fatos históricos e elementos do cotidiano infantil. Sobre o texto do norte-americano, Míriam escreve:

Um dos recursos mais utilizados pelo narrador no decorrer da obra A Child's Histoty of the World é promover curiosas associações entre determinados dados históricos e elementos que fazem parte do provável contexto em que está inserido o destinatário da mesma. Tais associações também devem despertar o seu interesse e facilitar a compreensão do que está sendo apresentado pelo texto ${ }^{132}$.

Para explicar a existência dos deuses cultuados pelos gregos, o narrador se vale da imagem de super heróis - comum às crianças, ou seja, atribui a eles o valor da fantasia em contra ponto ao Deus dos judeus.

The Greeks believe in many gods, not in one God as we do and as the Jews did, and their gods were more like people in fairy-tales than like divine beings. Many beautiful statues have been made of their different gods, and poems and stories have been written about them ${ }^{133}$.

Em trecho relativo à obra de Lobato, percebemos que o escritor brasileiro lança mão de outra estratégia para apresentar os deuses gregos às crianças. Ele retomou o conhecimento sobre os babilônicos que adoravam os astros:

Os gregos não tinham um deus único, como os judeus, nem adoravam astros, como os babilônicos. Possuíam doze deuses principais e um certo número de deuses menores, que moravam no Monte Olimpo, a mais alta montanha da Grécia ${ }^{134}$.

\footnotetext{
${ }^{131}$ Carta de Sylvio. IEB/ ARAS. Cx2P2doc22.

132 PALLOTA, Míriam Giberti Páttaro Pallota. Uma história ao contrário: um estudo sobre História do Mundo para as Crianças de Monteiro Lobato. Assis: UNESP, Faculdade de Ciências e Letras, 2001. (Tese de Doutorado). p.80.

${ }^{133}$ HILLYER, V.M. Child's History of The World. New York: Century, s/d. p.56.

${ }^{134}$ LOBATO, Monteiro. História do mundo para as crianças. 3 ed. São Paulo: Brasiliense, 1952. p.34.
} 
Dessa forma, percebemos que apesar de Monteiro Lobato ter se valido da obra Hillyer para a criação de sua História do Mundo para as Crianças, e de algumas semelhanças quanto ao tratamento dos textos e técnicas para alcançar os leitores, os dois escritores tinham concepções e projetos próprios de educação, Lobato apoiando a Escola Nova com Anísio Teixeira ${ }^{135}$ e Hillyer com as reformas de ensino na Calvert School.

O estudo comparando a versão brasileira de Lobato à obra de Virgil Hillyer é rico e vem sido desenvolvido por pesquisadores como Míriam Pallota em sua tese Uma história ao contrário: um estudo sobre História do Mundo para as Crianças de Monteiro Lobato, defendida em 2001 pela UNESP de Assis, e a Camila Russo de Almeida Spagnoli, que desenvolve dissertação no IEB - USP, estudando o processo de criação e estilo lobatiano.

Aqui, tivemos a intenção apenas de apontar mais uma das possíveis fontes de Monteiro Lobato para a criação de seu mundo helênico.

\subsection{Monteiro Lobato \& Coelho Neto}

Coelho Neto (1864-1934) foi figura importante no cenário intelectual brasileiro na virada para o século XX. Fundador da Cadeira 2 da Academia Brasileira de Letras, atuou como romancista, cronista, teatrólogo e crítico. Segundo Paulo Coelho Neto, o filho e biógrafo do autor:

"Coelho Neto escreveu 120 volumes, mas se lhe adicionassem todas as crônicas e artigos publicados nos jornais do país e do estrangeiro - aproximadamente 8.000 - aquele número oscilaria entre 280 e 300. Suas improvisações, que orçavam por 3.000, segundo cálculos do próprio escritor, dariam matéria para mais de 100 volumes contendo cada um dos 30 trabalhos. Ele deixou apenas 120 obras, quando poderia ter acumulado cerca de quatrocentas!”136

\footnotetext{
135 Cf. ABREU, Tâmara Costa e Silva. O livro para crianças em tempos de Escola Nova: Monteiro Lobato \& Paul Faucher. Tese de Doutorado (Orientação Marisa Philbert Lajolo). Campinas, SP: Instituto de Estudos da Linguagem, Universidade Estadual de Campinas, 2010.

136 Apud. MORAES, Marcos Antonio de. “Às quintas no tempo modernista” in: NETO, Coelho. Às quintas. 1ed. São Paulo: Martins Fontes, 2007.
} 
Além de escritor consagrado foi professor de História da Arte na Escola Nacional de Belas Artes e professor de História do Teatro e Literatura Dramática da Escola de Arte Dramática, onde também foi diretor.

Talvez essa biografia sumária ${ }^{137}$ do escritor maranhense nos dê uma ideia de sua importância na formação cultural do Brasil no início do século XX.

Coelho Neto serviu como referência para muitos jovens escritores dentre os quais Monteiro Lobato. Além de ser um dos incentivadores mais entusiasmados da cultura grega nessa época, como conta Brito Broca:

Era geralmente uma Grécia de cartolina, puramente decorativa, nada tendo de comum com o verdadeiro espírito helênico, que dominava por toda a parte. Dela usou e abusou, como todo mundo sabe, Coelho Neto, decerto um dos maiores propagadores dessa mania $^{138}$.

A presença de Neto é sensível na obra lobatiana, principalmente no que se refere à cultura clássica. Em seu artigo “Como se formam as lendas” publicado em Ideias de Jeca Tatu [1919], o escritor paulista apresenta figuras gregas que foram esboçadas por Coelho Neto para o cenário brasileiro:

Toda a arte antiga bebeu na fonte copiosa do riquíssimo "lendário" heleno, e de lá até nós nunca o velho tronco cessou de abrolhar vergônteas, viçosas nas Renascenças, bichadas nas Decadências, com o forte poder de sedução que leva Cellini a esculpir "Perseu", quando podia esculpir um condottieri de seu tempo, e Coelho Neto a esboçar “Artemis”, quando tanta Artemísia ${ }^{139}$ da cidade e do sertão anda ignorada a pedir pintura ${ }^{140}$.

Para além da referência a Coelho Neto na obra de Lobato, sabe-se que os escritores mantiveram correspondência. Mensagens do escritor maranhense encontramse no acervo do Fundo Monteiro Lobato. ${ }^{141}$

Em carta de 1918, Coelho Neto parabeniza seu "ilustre e poderoso confrade" pela “formidável impressão” de Urupês - publicado no mesmo ano:

$$
\text { Meu ilustre e poderoso confrade }{ }^{142}
$$

\footnotetext{
${ }^{137}$ Informações disponíveis no site da Academia Brasileira de Letras: <www.academia.org.br>. Acesso em: 01 out 2012.

${ }^{138}$ BROCA, Brito. A Vida Literária no Brasil 1900. 5ed. Rio de Janeiro: José Olympio, 2005, p.154.

${ }^{139}$ Nome de uma aldeia no oeste da montanha Taigeto em Messínia na Grécia.

${ }^{140}$ LOBATO, Monteiro. Ideias de Jeca Tatu. 13ed. São Paulo: Brasiliense, 1978. p.108.

${ }^{141}$ Disponível em: <www.unicamp.br/iel/monteirolobato>. Acesso em 5 ago 2012.

${ }^{142}$ Carta do Rio de Janeiro, 01 de novembro de 1918. Disponível sob o código: MLb 3.2.00221 cx4.
} 
Tendo de ir a S. Paulo realizar uma conferência na sede da Cultura Artística deixei para dizer-lhe em palestra a impressão formidável que recebi do seu livro "Urupês". É uma das mais robustas construções que tenho visto no campo das letras brasileiras e toda ela, dos alicerces à cúspide, feita com material da terra. Lá, em cavaco amigo, dir-lhe-ei a tristeza que me ficou da crueldade com que a sua pena alanceou o nosso mísero caboclo. Abonançada a Peste irei a S. Paulo com toda a minha turbulenta admiração abraçá-lo e oferecer-lhe a amizade desvaliosa de quem é um dos maiores entusiastas do seu talento impiedoso

Coelho Netto

A preferência de Lobato por seu "confrade” em relação a seus contemporâneos membros da Academia Brasileira de Letras pode ser percebida no artigo "Redimidos" publicado na Revista do Brasil em 1919:

Salvante alguns livros de Coelho Neto, de Afrânio Peixoto, de Lima Barreto, de Xavier Marques, de Veiga Miranda, de Canto e Melo, e um ou outro mais, a grande maioria dos volumes que aí surgem, quando não são obras didáticas, são obras poéticas. Esses os dois grandes mananciais literários no Brasil. Afastados, deixam minguadas porcentagens de obras em prosa de intenção meramente artística. Nem se compreenderia bem como, assim sendo, exista aí uma Academia de Letras de largo sodalício, cujas poltronas estejam sempre tomadas e a cujo liminar haja sempre uma turma de candidatos aos lugares por ventura vagos... ${ }^{143}$

Em carta de 16 de Julho de 1920, Coelho Neto comenta o contrato para a publicação de $O$ Mistério, publicado no mesmo ano, e sugere a publicação de outro título seu pela Revista do Brasil:

Ilustre confrade Sr. Monteiro Lobato ${ }^{144}$

A pedido do Afrânio assinei o contrato para a publicação d'O Mistério, moxinifada escrita à la diable (pelo menos por mim) e de muita má vontade. Que espera o meu amigo de tal balbúrdia? Não seria melhor que eu me inscrevesse na bibliografia da Revista do Brasil com alguma coisa mais decente, como, por exemplo, um volumete de contos do meu veranico, que tem por título Vesperal?

Confrade e admirador

Coelho Netto

A admiração entre os autores parece recíproca. Em seu artigo "Visão geral da literatura brasileira” publicado na revista Novela Semanal em 1921, Lobato discute o uso do que chama de "português bárbaro” usado pelo povo brasileiro, distante do latim

\footnotetext{
${ }^{143}$ LOBATO, Monteiro. Críticas e Outras Notas. 1 ed. São Paulo: Globo, 2009. p.33.

${ }^{144}$ Carta sob o código: MLb3.2.00251cx5.
} 
e do idioma lusitano, e aponta a falta de apoio público a escritores como Coelho Neto, compartilhando com ele preferências à forma clássica:

Dia a dia se acentua mais este fenômeno: o povo só lê, só apoia, só populariza a quem escreve a língua que fala. O extremado apego ao velho idioma fez novelistas eminentíssimos e fecundos, como Coelho Neto, que não gozaram, porém, do apoio público a que tinham direito. E a vitalidade da atual literatura, sua expansão, sua penetração dependem cada dia mais da adoção do "português bárbaro", que é idioma do povo brasileiro. O que aconteceu com o latim na Ibéria, dando origem ao idioma lusitano, está acontecendo no Brasil, no conflito daquele com o brasileiro nascente ${ }^{145}$.

Mas as conversas entre os escritores alinhavam assuntos limites literários à política brasileira. Em carta de fevereiro de 1921, Coelho Neto refere-se a uma “Contestação" com a qual teria impugnado a candidatura de Marcelino Machado em 1917, ano em que Neto se reelegeu deputado federal pelo Maranhão. Sugere ainda a publicação de outro texto “Atthidas”, com o qual contempla a campanha política no Maranhão, levando ainda como prefácio carta de Ruy Barbosa:

\section{Ilustre confrade Sr. Monteiro Lobato ${ }^{146}$}

Pedem-me, de vários pontos, a "Contestação" com que, em 1917, perante a Comissão de Poderes da Câmara, impugnei a eleição do grande Marcelino Machado. Conhece-o? Nem eu. É um tagante. Do número d'A Política em que apareceu não resta um exemplar. Apraz-lhe a ideia de fazermos uma tiragem de 2000 exemplares (150 a 180 páginas) de porte maneiro, que se traga no bolso, com os cigarros? Se formos felizes com a "Contestação", publicaremos as "Atthidas”, campanha política no Maranhão (discursos e conferências), levando como prefácio a carta de Ruy Barbosa. Responda-me.

Amigo e confrade Coelho Netto

Em missiva com o título de “Confidencial”, Coelho Neto compartilha com seu correspondente amigo dificuldades familiares e negocia com o editor o pagamento referente à segunda edição de $O$ Mistério, publicada pela editora de Monteiro Lobato:

\section{Lobato $^{147}$}

O ano continua no mesmo rumo trágico. Agora é uma filha que vai ser operada. Ando a bater moeda para fazer face ao ror de calamidades. Se já fechaste o balanço manda-me a parte que me cabe na $2^{\mathrm{a}}$ edição de $O$ Mistério.

\footnotetext{
${ }^{145}$ LOBATO, Monteiro. Críticas e Outras Notas. 1 ed. São Paulo: Globo, 2009. p.31.

${ }^{146}$ Carta do Rio de Janeiro, 17 de fevereiro de 1921. Disponível sob o código: MLb3.2.00259cx5.

${ }^{147}$ Carta de 27 de dezembro de 1922. Disponível sob o código: MLb 3.2.00301 cx6.
} 
Pensei em polir $O$ arara, a tal novela de Caliban cuja $1^{\text {a }}$ edição voou sem deixar um só exemplar. Para dá-la em edição nova, que negociarei sobre os originais, terei de copiá-la toda. Caso te convenha o negócio escreve-me.

Amigo Coelho Netto

Entre as cartas de Coelho Neto para Lobato, há também um bilhetinho ${ }^{148}$ com um “Voilà... e obrigadíssimo!” que nos vem aguçar a curiosidade.

E por meio da última carta, a qual tivemos acesso, o escritor de Vesperal menciona, em tom melancólico, suas várias publicações e deseja ao amigo, que na época estava nos Estados Unidos, ainda vê-lo "milhardário", no ano em que Lobato perderia todas suas economias com a Crise de 1929:

Meu caro Lobato ${ }^{149}$

Louvado seja o Senhor que ainda mantém no coração dos que estimo lembrança de mim. Se, em vez de me mandares parabéns, me houvesses enviado um pouco do frio que aí reina mais me teria agradado a tua carta. Essas coisas, porém, só aparecem em lendas. Em uma delas (do Rheno, creio) citada por Saul de Saint Victor, certo ondino vingadeiro consegue meter todo um rio dentro de uma carta.

Parabéns, por quê? Conheces bem as nossas apoteoses. Nas de Roma havia apenas um escravo para lembrar ao triunfador a sua condição mortal. Aqui, há toda uma legião a cochichar maldades. Enfim...

Quisera mandar-te uns livrecos das últimas fornadas, contiveme, porém, receoso de importunar-te. Penso, meu caro Lobato, que todo o meu mal vem da minha fecundidade. Não fosse eu coelho! Publico de mais.

Se eu limitasse a minha produção a um volume de 20 em 20 anos teria hoje, no máximo, 3 e, assim talvez me tomassem a sério. $\mathrm{O}$ struggle porém, obriga-me a multiplicar-me a isso...

E você? Que faz por aí? Com o seu talento e a sua tenacidade tenho certeza de que vencerá e no dia da vitória... ahn! isso será um tal chover dólares que nem sei! Aqui é a pingadeira e, quanto mais se trabalha menos se tem. Espero dos Lello o Fogo fátuo. Lá o terás. Abraço-te com o pensamento e espero ver-te ainda, milhardário, na casinha da rua do Rozo, hoje crismada com o meu nome. Tenho uma rua! Já é alguma coisa. Teu

Coelho Neto

Alguns anos depois da morte do amigo e confrade, Lobato questiona a formação que recebera dos “mestres da arte”, sobretudo de Coelho Neto, e a partir da leitura da obra da senhora Lendro Dupré, repensa suas ideias de literatura, como revela em carta a seu amigo Cesídio ${ }^{150}$ :

\footnotetext{
${ }^{148}$ Bilhete de 18 de janeiro de 1927. Disponível sob o código: MLb 3.2. 00355 cx 7.

${ }^{149}$ Carta do Rio de Janeiro, dia de São Sebastião de 1929. Disponível sob o código: MLb 3.2.00362 cx7.

${ }^{150}$ Carta com data provável de 1942.
} 
E quanto ao romance acho que você, como eu, como todo mundo, anda pecando por excesso de literatura. Tive a revelação disso agora - agora que é tarde e já estou me preparando para ir pregar em outra freguesia. E essa revelação me veio por intermédio duma mulher, a $\mathrm{Sr}^{\mathrm{a}}$ Leandro Dupré. Para que compreendas o meu pensamento, mando-te um romance dela que acaba de sair. Li-o em provas - e arregalei os olhos. Aprendi, afinal, a diferença entre literatura” e literatura; entre literatura e vida. E sem que ela me pedisse, sem que sequer eu a conhecesse, escrevi dum jacto 12 páginas de prefácio. Isso, para pôr o dedo numa coisa que me parece muito séria: a diferença de literatura aspada e literatura sem aspas. Leia-o e estude o caso. Você está moço e ainda pode aproveitar-se da lição. O segredo do encanto dessa mulher parece-me estar na absoluta ausência de "literatura" - e nós não sabemos escrever sem literatura. Nossos mestres de arte (sobretudo Coelho Neto) nos inocularam uma noção errada de arte. Eles é que nos asparam literariamente. Machado de Assis foi uma reação - mas quem ainda compreende Machado de Assis $^{151}$ ?

Na carta, Lobato orienta o jovem escritor a tomar cuidado e não pecar pelo “excesso de literatura”, ou de uma "noção errada de arte”, a qual aprenderam com os mestres dentre os quais Coelho Neto, apontando ainda a obra de Machado de Assis como uma reação àquilo que chama de "literatura aspada", ou seja, entre aspas.

Infelizmente, não tivemos acesso nesta pesquisa às cartas de Lobato a Coelho Neto, mas pudemos perceber a cordial relação entre os escritores, vínculo intelectual que também trouxe à tona o mundo clássico.

151 TIN, Emerson. Em busca do "Lobato das cartas": a construção da imagem de Monteiro Lobato diante de seus destinatários. Campinas: Universidade Estadual de Campinas, 2007 (Tese de Doutorado). p.370. 


\title{
4. Minha Grécia de Monteiro Lobato: conclusão, reinício
}

\begin{abstract}
"Os seus melhores retratos são A Barca de Gleyre e a Emília. Se perguntassem qual dos dois prefiro eu responderia como as crianças quando se sentem em apuros: 'Prefiro mais os dois!' Assim como é difícil encontrar o coração de Monteiro Lobato, é dificílimo decidir se Emília tem ou não tem coração. Por muito tempo julguei que ela não tivesse nem isca de coração. Tinha, isso sim, um cerebrozinho tão atilado, tão acertadamente ativo, que agia, quando preciso, à guisa de coração. Mas agora, nos Trabalhos de Hércules, Emília apresentou ao mundo uma 'ameaça de coração'. Quando depois da viagem à Grécia mostra as relíquias trazidas e Dona Benta lhe pergunta qual a que mais prezava, ela responde sem hesitação que eram as lágrimas de Hércules. Dona Benta quis saber onde as guardara e Emília, batendo no peito, responde: - Aqui, no meu coração" (Marina de A. Procópio de Carvalho) ${ }^{152}$,"
\end{abstract}

Nesses últimos anos de pesquisa, Monteiro Lobato me ensinou muito de História, Grécia, Literatura e Leitura. Mas, para além disso, descobri com ele que os textos são produzidos a partir de escolhas, construções, desconstruções e reconstruções do que aprendemos e vivemos. Percebi que não apenas o processo criativo de um autor é dinâmico, mas também sua formação como um todo. Pois, para estudar a “origem” da Grécia de Lobato, foi necessário buscar documentos do seu tempo de menino, época em que escreveu bilhetinhos à mãe; reler mensagens ${ }^{153}$ do jovem apaixonado que se sente 0 próprio Ulisses diante de Penélope; resgatar suas indicações de leituras - por vezes entediadas; examinar suas traduções e recompor o registro do trabalho duro. Ofício de ser escritor.

Assim também é a pesquisa. Buscar reconstruir a Grécia de Monteiro Lobato não foi tarefa fácil. Investigando extenso acervo de fonte primária e obra vasta, tendo em vista o estudo do processo de criação, ambicionamos recompor um “quebra-cabeça”, do qual não temos certeza da quantidade de peças e nem sua disposição no jogo. Ou seja, quando recuperamos leituras do escritor e indícios do seu processo de escritura, por maior que seja a quantidade de documentos reunidos e o esforço que empenhemos nesse processo, ainda sim, é apenas uma possibilidade de “ordem de encaixe” dentre as

\footnotetext{
${ }^{152}$ Texto escrito por Marina de Andrada Procópio de Carvalho como abertura para os Prefácios e Entrevistas de Monteiro Lobato. p. XVI - XVIII.

${ }^{153}$ LOBATO, Monteiro. Cartas de Amor. São Paulo: Globo, 2011. p. 167-168.
} 
inúmeras possíveis. Já que, como nos alerta Almuth Grésillon, “O traço conservado é apenas um distante e fugido testemunho de uma outra cena.”154

Diante de tantas dúvidas e imprecisões, qual seriam então as razões que motivariam o estudo do processo criativo de um escritor? Assim como é grande a quantidade de incertezas nesse caminho, há também uma infinidade de possíveis respostas.

Uma primeira sugestão de resposta é a tentativa de desmistificar o processo de criação dos autores, considerado por alguns, fruto de pura inspiração. Trata-se de humanizar o criador, reconhecendo-o como um sujeito com vivências que muitas vezes transparecem em seus textos, vistos como resultado de experiências cotidianas e de leituras.

Outra possível razão é o desejo de se conhecer uma forma de criação, de fazer arte e de aproximar-se desses grandes homens e mulheres (e talvez aprender com eles), representantes da cultura brasileira. Sendo assim, vejo, também como professora, os estudos de crítica genética como uma importante ferramenta pedagógica, acolhendo ainda a sugestão de Grésillon:

Por acaso, nunca se pensou em mostrar aos alunos da escola primária com grandes dificuldades para dominar os movimentos físicos forçados da escrita manuscrita e que, um pouco mais tarde, devem aprender a redigir, por acaso nunca pensamos em mostrar-lhes a energia gasta pelos escritores sobre suas folhas de rascunhos? ${ }^{155}$

Explicar os motivos ou justificativas desta pesquisa seria uma tarefa hercúlea, por isso optamos apenas em revelar alguns dos caminhos que percorremos em seu desenvolvimento.

Passeando pelo universo criativo apresentado por Lobato, pudemos ver de perto a quantidade de referências à Grécia que perpassam sua obra. A Seleta resultante da pesquisa abre-se para múltiplos caminhos, como o labirinto do Minotauro:

\footnotetext{
${ }^{154}$ GRÉSILLON, Almuth. Elementos de crítica genética: ler os manuscritos modernos. Porto Alegre: Editora UFGRS, 2007. p.41.

${ }^{155}$ GRÉSILLON, Almuth. Elementos de crítica genética: ler os manuscritos modernos. Porto Alegre: Editora UFGRS, 2007. p.35.
} 
Encontramos uma Grécia que serve a Lobato de parâmetro e vai moldando as percepções do escritor. Hércules, uma das figuras mitológicas de maior destaque em sua obra, é apresentado em carta pelo jovem Lobato aos seus vinte anos como "fascinante de vibração, de fogo, de selvageria”, quando comparado ao teor da mensagem ${ }^{156}$ do amigo Lino Moreira. Trinta anos depois, em América, já casado e com filhos, o escritor descreve o homem americano ${ }^{157}$ como Hércules e a mulher como uma "perfeita Ônfale”, esposa a quem o semideus serviu. Mais tarde, em 1947, n’Os Doze Trabalhos de Hércules, o herói é caracterizado como um "bruto”, que ao final de suas façanhas reconhece que "a educação é que faz as criaturas ${ }^{158 \text { ”. }}$

Semelhante relação podemos estabelecer com outras personagens que se transfiguram no decorrer da vida e obra do autor, como a tríade Fídias, Péricles e Aspásia, figurando em Literatura de Minarete, História do Mundo para as Crianças e O Minotauro. Essas personalidades do mundo grego representam diferentes questões como: o amor não correspondido, a política, a estética artística, o incentivo à cultura.

Ao relacionar Grécia e Monteiro Lobato, constatamos que esse gosto pela cultura clássica era muito mais antigo do que supúnhamos inicialmente. Do jovem que apenas lia para o escritor que produzia literatura, encontramos muitas referências, acompanhamos seus processos de leitura e estabelecemos diálogos com três principais fontes: Will Durant, V. M. Hillyer e Coelho Neto. Em uma trajetória de diálogos intertextuais, processo de criação e recriação, mergulhamos na Grécia de Lobato; lá encontramos capítulos, personagens e até obras inteiras dedicadas à cultura helênica, um universo de mitos e personagens gregos, com a preocupação lobatiana de sempre aproximá-los da cultura brasileira.

Assim como esta dissertação abebera-se de estudos de outros pesquisadores, poderá contribuir para novos trabalhos focalizando a presença da Grécia na obra desse ilustre intelectual. Lobato, tão polemicamente amado e odiado, que foi editor, tradutor, revisor, fazendeiro, empresário, adido comercial, dentre tantas outras atividades culturais, fez morada no coração das crianças por gerações inteiras (independentemente da idade delas). Lobato segue inesgotável.

\footnotetext{
${ }^{156}$ LOBATO, Monteiro. Cartas Escolhidas. São Paulo: Brasiliense, 1959. p. 63. Carta de 1902.

${ }^{157}$ LOBATO, Monteiro. América. São Paulo: Globo, 2009. p.63.

${ }^{158}$ LOBATO, Monteiro. Os Doze Trabalhos de Hércules. 8ed. São Paulo: Brasiliense, 1957. $2^{\circ}$ Tomo. p. 292.
} 


\section{BIBLIOGRAFIA}

\subsection{Obras de Monteiro Lobato}

\section{Literatura adulta:}

LOBATO, Monteiro. O saci-pererê: resultado de um inquérito. 1 ed. São Paulo: Globo, 2008.

LOBATO, Monteiro. Urupês. 24 ed. São Paulo: Brasiliense, 1980.

LOBATO, Monteiro. Problema Vital. 2 ed. São Paulo: Brasiliense, 1948.

LOBATO, Monteiro. Cidades Mortas. São Paulo: Brasiliense, 1946.

LOBATO, Monteiro. Ideias de Jeca Tatu. 13ed. São Paulo: Brasiliense, 1978.

LOBATO, Monteiro. Negrinha. 3 ed. São Paulo: Brasiliense, 1950.

LOBATO, Monteiro. Onda Verde. 1 ed. São Paulo: Globo, 2008.

LOBATO, Monteiro. Mundo da Lua e Miscelânea. 2ed. São Paulo: Brasiliense, 1948.

LOBATO, Monteiro. O Garimpeiro do Rio das Garças. 4 ed. São Paulo: Brasiliense, 1995.

LOBATO, Monteiro. O Presidente Negro. 1ed. São Paulo: Globo, 2010.

LOBATO, Monteiro. Mrs. Slang e o Brasil. 2 ed. São Paulo: Brasiliense, 1948.

LOBATO, Monteiro. América. 1ed. São Paulo: Globo, 2009.

LOBATO, Monteiro. Na Antevéspera. s/ed. São Paulo: Brasiliense, 1946.

LOBATO, Monteiro. O Escândalo do Petróleo e do Ferro. 8ed. São Paulo: Brasiliense, 1956.

LOBATO, Monteiro. A Barca de Gleyre: Quarenta anos de correspondência literária.

São Paulo: Cia Editora Nacional, 1944.

LOBATO, Monteiro. Prefácios e Entrevistas. 8 ed. São Paulo: Brasiliense, 1957.

LOBATO, Monteiro. Georgismo e o Comunismo. São Paulo: Brisiliense, 1948.

LOBATO, Monteiro. Literatura do Minarete. São Paulo: Brasiliense, 1959.

LOBATO, Monteiro. Cartas Escolhidas. São Paulo: Brasiliense, 1959.

LOBATO, Monteiro. Críticas e Outras Notas. 1 ed. São Paulo: Globo, 2009.

LOBATO, Monteiro. Cartas de Amor. 1 ed. São Paulo: Globo, 2011. 


\section{Literatura Infantil:}

LOBATO, Monteiro. A menina do Narizinho Arrebitado. São Paulo: Monteiro Lobato \& Cia, 1920.

LOBATO, Monteiro. Fábulas. 8 ed. São Paulo: Brasiliense, 1957.

LOBATO, Monteiro. O saci. 31 ed. São Paulo: Brasiliense, 1978.

LOBATO, Monteiro. Jeca Tatuzinho. 14 ed. São Paulo: Instituto "Medicamenta" Fontoura \& Serpe, 1946.

LOBATO, Monteiro. Aventuras de Hans Staden. 1 ed. São Paulo: Globo, 2007.

LOBATO, Monteiro. Peter Pan. 21 ed. São Paulo: Brasiliense, 1978.

LOBATO, Monteiro. Reinações de Narizinho. 8ed. São Paulo: Brasiliense, 1957.

LOBATO, Monteiro. Viagem ao Céu. 1 ed. São Paulo: Globo, 2007.

LOBATO, Monteiro. História do mundo para as crianças. 3 ed. São Paulo: Brasiliense, 1952.

LOBATO, Monteiro. Caçadas de Pedrinho. 1ed. São Paulo: Globo, 2008.

LOBATO, Monteiro. Emília no País da Gramática. 1 ed. São Paulo: Globo, 2008.

LOBATO, Monteiro. História das Invenções. s/ed. São Paulo: Círculo do Livro, s/d.

LOBATO, Monteiro. Aritmética da Emília. 1ed. São Paulo: Globo, 2009.

LOBATO, Monteiro. Geografia da Dona Benta. 8 ed. São Paulo: Brasiliense, 1957.

LOBATO, Monteiro. Memórias da Emília. 1ed. São Paulo: Globo, 2007.

LOBATO, Monteiro. Dom Quixote das Crianças. S/ ed. São Paulo: Círculo dos Livros, s/d.

LOBATO, Monteiro. Serões de Dona Benta. 22ed. São Paulo Brasiliense, 1994.

LOBATO, Monteiro. O Poço do Visconde. São Paulo: Brasiliense, 1957.

LOBATO, Monteiro. Histórias de Tia Nastácia. 7ed. São Paulo: Brasiliense, 1957.

LOBATO, Monteiro. Picapau Amarelo. 7ed. São Paulo: Brasiliense, 1957.

LOBATO, Monteiro. O Minotauro. 7ed. São Paulo: Brasiliense, 1957.

LOBATO, Monteiro. A Reforma da Natureza. 1ed. São Paulo: Globo, 2008.

LOBATO, Monteiro. A Chave do Tamanho. 17 ed. São Paulo: Brasiliense 1979.

LOBATO, Monteiro. Os Doze trabalhos de Hércules. 10ed. São Paulo: Brasiliense, 1960 . 


\subsection{Obras sobre Monteiro Lobato}

ABREU, Tâmara Costa e Silva. O livro para crianças em tempos de Escola Nova: Monteiro Lobato \& Paul Faucher. Tese de Doutorado (Orientação Marisa Philbert Lajolo). Campinas, SP: Instituto de Estudos da Linguagem, Universidade Estadual de Campinas, 2010.

ANDREOTTI, Azilde Lina. A formação de uma geração: educação para a promoção social e o progresso de país do jornal A Voz da Infância da Biblioteca Infantil Municipal de São Paulo (1936-1950). Campinas: Universidade Estadual de Campinas, 2004 (Tese de Doutorado).

ARAÚJO,Roosevelt. “A Grécia pelos olhos de Emília: Lobato e sua leitura da Antiguidade Clássica” IN: 17 Congresso de Leitura (COLE), Unicamp, 2009.

ARAÚJO,Roosevelt. “A Grécia pelos olhos dos Picapaus: Lobato e sua leitura da Antiguidade Clássica” IN: Revista Letras, Curitiba, n. 78, p.85-95, mai/ ago 2009. Editora UFPR.

BEDÊ, Ana Luiza Reis. Monteiro Lobato e a presença francesa em A barca de Gleyre. São Paulo: Annablume/ Fapesp, 2007.

BRATSIOTIS, Ericka Sophie. A mitologia grega na obra O Minotauro de Monteiro Lobato. São Paulo: Universidade Presbiteriana Mackenzie, 2006 (Dissertação de Mestrado).

CASSAL, Sueli Tomazini Barros. Amigos escritos: correspondência literária entre Monteiro Lobato e Godofredo Rangel. São Paulo: Imprensa Oficial do Estado de São Paulo/ Oficina do Livro Rubens Borba de Moraes, 2002.

CAVALHEIRO, Edgard. Monteiro Lobato: vida e obra. São Paulo: Nacional, 1955.

LACERDA, Vitor Amaro.Um mergulho na Hélade: mitologia e civilização grega na literatura infantil de Monteiro Lobato. Belo Horizonte: UFMF, Faculdade de Letras, 2008. (Dissertação de Mestrado).

LAJOLO, Marisa. (Org.); CECCANTINI, João Luis (Orgs.). Monteiro Lobato livro a livro (obra infantil). São Paulo: Editora Unesp/Imprensa Oficial, 2008.

MAZIERO, Maria das Dores Soares. Mitos gregos na literatura infantil: que Olimpo é esse? Campinas: Unicamp, Faculdade de Educação, 2006. Dissertação de mestrado orientada pela Profa. Dra. Norma Sandra de Almeida Ferreira.

NUNES, Cassiano (org.) Monteiro Lobato Vivo. Rio de Janeiro: MPM Propaganda/Record, 1986. 
OLIVEIRA, Diva de. Os doze trabalhos de Hércules: a estilização do mito na obra Lobatiana. São Paulo: Universidade Presbiteriana Mackenzie, 2006 (Dissertação de Mestrado).

PALLOTA, Míriam Giberti Páttaro Pallota. Uma história ao contrário: um estudo sobre História do Mundo para as Crianças de Monteiro Lobato. Assis: UNESP, Faculdade de Ciências e Letras, 2001. (Tese de Doutorado).

PINHEIRO, Valter.“Arte grega clássica e arte moderna: aspectos axiológicos em $O$ Minotauro”. IN: Revista Fronteira Z, São Paulo, n. 6, abril de 2011.

SILVA, Adriana Paula dos Santos. A paródia em Monteiro Lobato: adaptações clássicas. In: CELLI - COLÓQUIO DE ESTUDOS LINGUÍSTICOS E LITERÁRIOS. 3, 2007, Maringá. Anais... Maringá, 2009, p. 11-23.

SILVA, Raquel Afonso de. Entre livros e leituras : um estudo de cartas de leitores. Campinas: Unicamp, Instituto de Estudos da Linguagem, 2009. (Tese de Doutorado).

TIN, Emerson. Em busca do "Lobato das cartas": a construção da imagem de Monteiro Lobato diante de seus destinatários. Campinas: Universidade Estadual de Campinas, 2007 (Tese de Doutorado).

TOPAN, Juliana de Souza. O "Sítio do Pica-pau Amarelo da Antiguidade": singularidades das “Grécias” lobatianas. Campinas: Unicamp, Faculdade de Educação, 2007 (Dissertação de Mestrado).

\subsection{Will Durant}

DURANT, Will. The Story of Civilization. Vol. I: Our Oriental Heritage. New York: Simon and Schuster, 1935.

DURANT, Will.The Story of Philosophy: The Lives and Opinions of the Greater Philosophers. New York: Simon and Schuster, 1926.

DURANT, Will.The Story of Civilization. Vol. II: The Life of Greece. New York: Simon and Schuster, 1939.

DURANT, Will.The Story of Civilization. Vol. III: Caesar and Christ. New York: Simon and Schuster, 1944.

DURANT, Will.Great Men of Literature. New York: Garden City Publishing co. inc., 1936. 
DURANT, Will.Taken from Adventures in Genius. The Mansions of Philosophy: A Survey of Human Life and Destiny. New York: Simon and Schuster, 1929.

DURANT, Will.História da Civilização. Vol. II. A Vida na Grécia. 3ed. São Paulo: Companhia Editora Nacional, 1957.

DURANT, Will. História da Filosofia. s/ed. São Paulo: Cia Editora Nacional, [19- -].

DURANT, Will. The Story of Civilization. Vol. II. The life of Greece. New York: Simon and Schuster,1939.

\subsection{Virgil Mores Hillyer}

HILLYER, V.M. Child's History of The World. New York: Century, s/d.

\subsection{Coelho Neto}

NETO, Coelho. Às quintas. 1ed. São Paulo: Martins Fontes, 2007.

\subsection{Crítica genética e Biblioteca de escritores}

GRÉSILLON, Almuth. Elementos de crítica genética: ler os manuscritos modernos. Porto Alegre: Editora UFGRS, 2007.

HAY, Louis. A literatura dos escritores. Questões de crítica genética. Belo Horizonte: Editora UFMG, 2007.

JACICSON, H.J. Marginalia: readers writing in books. New Itaven/ Londres. Yale University Dren, 2001.

LOPEZ, Telê Ancona. “A Biblioteca de Mário de Andrade: seara e celeiro de criação”. In: ZULAR, Roberto (org). Criação em Processo: ensaios de crítica genética. São Paulo, FAPESP/ Iluminuras/ CAPES, 2002.

MORAES, Marco Antonio. Correspondência Mário de Andrade \& Manuel Bandeira. São Paulo: Edusp/IEB, 2000.

PINO, Claudia Amigo e ZULAR, Roberto. Escrever sobre escrever: uma introdução crítica à crítica Genética. São Paulo: Martins Fontes, 2007.

SALLES, Cecília Almeida. "Crítica Genética e outros campos do conhecimento”. In: PINO, Claudia Amigo (org). Criação em debate. São Paulo: Humanitas/ Capes, 2007.

WILLEMART, Philippe. Crítica genética e psicanálise. São Paulo: Perspectiva, 2005.

WILLEMART, Philippe. Universo da criação literária. São Paulo: Edusp, 1993. 


\subsection{Teoria Literária e Leitura:}

BOSI, Alfredo. História concisa da literatura brasileira. São Paulo: Cultrix, s.d.

BROCA, Brito. A Vida Literária no Brasil 1900. 5ed. Rio de Janeiro: José Olympio, 2005.

CANDIDO, Antonio. Formação da literatura brasileira: momentos decisivos , 17501880. 12 ed. São Paulo: Rio de Janeiro: Ouro sobre Azul, 2009.

CARVALHO, Ronald de. Pequena História da Literatura Brasileira. 4 ed. Rio de Janeiro: F. Briguiet \& Cia, 1929, p. 412.

EAGLETON, Terry. Teoria da Literatura: uma introdução. 6ed. São Paulo: Martins Fontes, 2006.

LAJOLO, Marisa. Literatura: Leitores \& Leitura. São Paulo: Moderna, 2007.

LAJOLO, Marisa; ZILBERMAN, Regina. A Formação da Leitura no Brasil. 2ed. São Paulo: Ática, 1998.

\subsection{Sites}

Monteiro Lobato e outros Modernistas Brasileiros. Disponível em: $<$ http://www.unicamp.br/iel/monteirolobato>.

Will Durant Foundation. Disponível em: <www.willdurant.com>.

Conversa entre amigos: correspondência escolhida entre Anísio Teixeira e Monteiro Lobato. Disponível em: <www.bvanisioteixeira.ufba.br/cartas/lobato2.html >

Calvert School, Disponível em: <http://homeschool.calvertschool.org/sectiontest/7/265-hillyers-vision>. 


\section{SELETA ${ }^{159}$}

PARTE 1: Transcrição de trechos relativos à Grécia em livros de Monteiro Lobato ${ }^{160}$

- Obra adulta:

LOBATO, Monteiro. O Saci Pererê: resultado de um inquérito. São Paulo: Globo, $2008(1918)^{161}$.

\section{“Depoimento de uma menina ${ }^{162 "}$}

“Cumpre, porém esclarecer que um dos narradores afirmara que o Saci-pererê nascera em Minas (sem paternidade), pois - como Palas saindo armada da cabeça de Zeus - fora garimpando estrugindo num salto violento o colmatado cômoro próximo, a falinha aguda e estridente saci-saci e arrepiada, me recolhia timorata do terreiro a me aconchegar no recesso ameno do lar onde se esvaíam os temores ao contato doce da maman carinhosa.” [p.124]

\section{“Depoimento do senhor Vieira Lessa”}

"Habitava outrora em Pindamonhangaba, em tempos que lá se vão, uma certa matrona, senhora respeitável e possuidora de avultados cabedais, entre estes alguns escravos. Esta dama, excessivamente religiosa, tinha por hábito invariável rezar todas as noites o seu terço antes de se entregar a Morfeu.” [p.185]

\section{“Depoimento do senhor Luiz Fleury, de Sorocaba”}

"Como da aludida tentativa de superstições resultasse uma tal confusão amorfa de imagens, que impossível me fora precisar a incoerência compósita dos contornos, passei a suspeitar houvesse várias espécies de sacis, ou, pelo menos, que o duendezinho fosse um êmulo de Proteu...” [p.237]

LOBATO, Monteiro. Urupês. São Paulo: Globo, 2007 (1918).

“Um suplício moderno”(1916)

“Vencer! Oh, néctar Oh, ambrosia incomparável!” [p.76]

\footnotetext{
${ }^{159}$ Por serem obras com a temática grega, os trechos selecionados de O Picapau Amarelo, O Minotauro e Os Doze Trabalhos de Hércules serão apresentados no próximo relatório, servindo como parâmetro da Grécia construída por Lobato.

160 O levantamento dos trechos referentes à Grécia na obra de Monteiro Lobato é parcial e será apresentado em sua totalidade no relatório final.

${ }^{161}$ Os livros da editora Globo vêm com indicação de primeira edição, desconsiderando as edições anteriores publicadas por outras editoras.

${ }^{162}$ Em comentário prévio ao depoimento Lobato escreve: “Chamava-se M. Aurorita. Tem apenas 16 anos. E seu depoimento exala masculinidade. Desconfio dela. É uma aurora a falar de meia noite com erudição de curiango."
} 


\section{“O Mata-pau”(1915)}

"Imaginação envenenada pela literatura, pensei logo nas serpentes de Laooconte, na víbora aquecida no seio do homem da fábula, nas filhas do rei Lear, em todas as figuras clássicas da ingratidão”. [p.110]

\section{“O estigma”(1915)}

"Pude então ver o estigma. Era perfeita a ilusão: lá estava a imagem do orifício aberto pelo projétil e do fio de sangue escorrido.

- Veja você - concluiu o meu triste amigo - os caprichos da natureza...

- Caprichos de Nêmesis... - ia eu dizendo, mas o olhar do pai cortou-me a palavra: o moço ignorava o crime de que fora ele próprio o eloquente delator”. [p.157]

\section{“Urupês”(1914)}

“A ideia de Deus e dos santos torna-se jecocêntrica. São os santos os gaúchos lá de cima, os coronéis celestes, debruçados no azul para espreitar-lhes a vidinha e intervir nela ajudando-os ou castigando-os, como os mestiços deuses de Homero. Uma tortura de pé, um estrepe, o feijão entornado, o pote que rachou, o bicho que arruinou - tudo diabruras da corte celeste para o castigo de más intenções ou atos”. [p.176]

\section{LOBATO, Monteiro. Problema Vital. 2 ed. São Paulo: Brasiliense, 1948 (1918). \\ “Déficit econômico, função do déficit da saúde”}

“O Brasil, São Paulo fora, exporta por cabeça 23.000 réis anuais. Sessenta e quatro réis, três vinténs e pico por dia de 24 horas...

Desta caqueixa econômica ressurte o monstro do déficit financeiro permante, crescente e irredutível, que rói ao Prometeu o fígado e as vísceras cunvizinhas.” [p.274275]

\section{LOBATO, Monteiro. Cidades Mortas. São Paulo: Brasiliense, 1946 (1919).}

\section{“Gens ennuyeux” (1901)}

“Ao assomarmos à porta já as cadeiras do grande salão se pintalgavam de graves sobrecasacas científicas, encimadas por carecas luzidias, em cujo espelho punha gangrenas de luz (perdão, Apolo!) a luz violácea do arco voltaico”. [p.89]

[...] Nós, miserandos intrusos, vexados da nossa espessa ignorância a dois, comentávamos baixinho, com respeitosa deferência, as efígies hirsutas daqueles paredros que davam de tu a Minerva”. [p.91]

\section{“O fígado indiscreto” (1904)}

"Acontece, todavia, que esses deuses, ao jeito dos de Homero, também cochilam: e o borracho parte o nariz de encontro ao lampião, ou futura sogra lá apanha 
Romeu e Julieta em flagrante contato de mucosas petrificando-os com o clássico: 'Que pouca vergonha!...’ [p.99]

[...] Chegou a rir-se. Riu-se alvarmente, de gozo, como riria Hércules após o mais duro dos seus trabalhos”. [p.102]

\section{“O plágio”}

"E foi pelo caminho a redizê-la com cariciosa unção, a remira-la de todos os lados, sob todas as luzes. Degustou-a em surdina inúmeras vezes; pela forma, revendo o jeito com que a fixaram no papel os caracteres tipográficos; pelas correlações associadas, evocando vagos helenismos clássicos que o padre mestre Jordão lhe embutira no cérebro a palmatoadas - Frineia ${ }^{163}$, o cão de Alcibíades, as Termópilas, o barril de Diógenes”. [p.111]

\section{“O luzeiro Agrícola” (1910)}

“- Eu? Eu... fui poeta. Cantei o amor, a Mulher, a Beleza, as manhãs cor de rosa, as auroras boreais, a natureza, enfim. Romântico, embriaguei-me na Taverna de Hugo. Clássico, bebi o mel do Himeto pela taça de Anacreonte. Evoluído para o parnasianismo, burilei mármores de Paros com os cinzéis de Heredia. Quando quebrei a lira, estava ascendendo ao cubismo transcendental. Sim, general, sou um gênio incompreendido, novo Asverus a percorrer todas as regiões do ideal em busca da Forma Perfeita. Qual Prometeu, vivi atado ao potro do Inania Verba, onde me roeu o Abutre da Perfeição Suprema. Fui um Torturado da Forma...” [p.133-134]

\section{“De como quebrei a cabeça à mulher de Melo"(1906)}

"Não houve escapatória possível; tive que aceitar o truculento prato de caroços pretos, coisa que detesto. Olhei para a rodela escura, cor de chocolate, que se me esparramava pelo prato inteiro sem deixar transparecer uma nesga sequer da louça branca, enchi-me de resignação e empreendi o trabalho de Hércules que era trasladar tudo aquilo para o estômago”. [p.154]

\section{“O espião alemão” (1916)}

"Os grandes condutores de povos: simples vontades de aço despidas de inteligência, incapazes doutra filosofia que não a das maxilas da hiena. Por que eles perpetuam a guerra, a humanidade os erige em semideuses. E com eles, poetas, pensadores, generais, a indústria, o comércio, a imprensa, todos, todos e tudo - fora as mães - zelam, como vestais, para que se não extinga o fogo sagrado do Ódio. Já para os deuses, de Júpiter a Jeová, era a vingança o prazer supremo. Se sabe assim a guerra a paladares divinos, que admira saber tanto ao macaco glabro que se classificou a si próprio Homo sapiens, ignorante de como o classificariam os cavalos?” [p.161]

[...] E pondo na cabeça o chapéu felpudo, saiu solene e sábio como a própria Minerva de batina e coroa”. [p.171]

\footnotetext{
${ }^{163}$ Cortesã grega do século III a. C.
} 


\section{“Anta que berra”}

"Depois latiu a Tatuíra. Era mais sério. Tatuíra, por Mozart e Minerva, herdada do pai as sólidas qualidades de mestre, prejudicadas, porém, por umas excentricidades histéricas da mãe, que, coitada, morreu hidrófoba”. [p.188]

\section{LOBATO, Monteiro. Ideias de Jeca Tatu. 13ed. São Paulo: Brasiliense, 1978 (1919).}

\section{“A caricatura do Brasil”}

"Diga-se, por exemplo, da caricatura, maldade velha que nasceu quando o animal que ri farejou no repuxo dos músculos faciais um meio de matar às claras matar moralmente, já se vê. E que nasceu na Grécia para veículo dum sutil alcaloide de nome 'eironeia', do qual foi Sócrates um hábil manipulador. E desde então nada se forrou a esse veneno - nem homens, nem deuses, nem cavalos. O que sucedeu a Pégaso deve ser dito a todas as alimárias de quatro pés ou dois, para lembrete da inanidade das prosápias cavalinas.

Não valeu a Pégaso ser um Moisés hípico, abridor de fontes e coices; nem lhe valeu honrá-lo Apolo com os seus divinos fundilhos, no dia em que a visita a Baco o encavalou em pelo, com as nove musas à garupa. Nem lhe valeu a gloria de puxar o carro da Aurora. Irreverentes homens de Atenas caricaturaram-no de asno enfeitado com asas de ganso, a tropicar pelo cabresto de um Belerofonte manso e amarrotado de um tombo recente.

Zeus, lá do Olimpo, não gostou da brincadeira e esbrugou o cavalo magnífico em mil pedaços, estrelejando com eles o céu na zona compreendida entre a constelação de Hércules e a dos Peixes. Mas o seu avatar asinino cá ficou na terra, murcho de orelhas, atido à prebenda de levar ao Parnaso, no trote, os meninos que ali pelos 18 anos quebram pés a versos e correm a chorar sonetos no colo da boa Polinia todas as vezes que brigam com a namorada.

Depois de Pégaso, Júpiter.

Um discípulo de Apeles pintou uma tela humorística de grande voga: 'Júpiter parindo Baco’. De mitra à cabeça, o deus dos deuses esquece a serenidade e berra como descompassado ilota da Lacônia, ponde em dobadoura as deusas ali reunidades com paninhos, bacias e mais farragem obstétrica.

E de Jove para cá ninguém mais teve imunidades. Descerre quem for curioso às cortinas da História e espie dentro das Épocas - das oxigenadas como a Renascença às pestíferas como aquele sanioso Ano Mil de lúgubre memória - e lá verá a Caricatura latindo contra todas as prepotências do farisaísmo de mil caras.” [p.3-4]

\section{“Como se formam as lendas"}

“Em belas conferências explora Afonso Arinos o veeiro inexaurível da lenda alma das raças cristalizadas pela tradição.

Porque no anelo vago, embora premente, de refugir ao prosaísmo da vida, que toda se resume no comer o pão de hoje, digeri-lo sob um teto e amassar o de amanhã, o homem do povo - seja um ilota de Atenas, um trânsito pela rua da Cerâmica, apregoando figos de uma quinta à margem do Ilisso, o qual cruza a caminho do Ágora, a discutir com Fídias um detalhe do Partenão; seja um caipira de Areias, que sobe a rua do Cabrito anunciando grumixamas dum quintal que dá para o Ribeirão Vermelho, o 
qual cruza o promotor, a caminho do fórum, a debater com o juiz o caso duma goteira na sala do júri - o homem do povo despica-se de materialidade deprimente desferindo voos pelos intermúndios do sonho.

A insofreável musa do Devaneio encarcerada em cada peito humano, seja Guilherme Shakespeare ou Zé Pichorra, deturpa a realidade, enfolha-a, enflorece de poesia - da sã poesia que se não molda por figurinos mas sai da alma com a espontaneidade de perfumes vaporados de resedás - por exalação funcional.

Tal poesia é a matéria cósmica da lenda.

O Olimpo grego!...

Os gregos estilizaram-no em verso, escultura e teatro, de Hesíodo a Escopas. Antes, porém, o Olimpo viveu em massa informe a bosquejar-se na imaginação do heleno, a bruxolear nos sonhos dos vagos pelásgicos, frígios e fenícios interferentes na gênese grega. E, remontando inda mais alto, vislumbram-se-lhe as primeiras lucilações na grande madre asiática do planalto donde tudo saiu, inclusive a mancenilheira desta civilização que ora explode numa suprema safra de sangue.

Toda a arte antiga bebeu na fonte copiosa do riquíssimo ‘lendário’ heleno, e de lá até nós nunca o velho tronco cessou de abrolhar vergônteas, viçosas nas Renascenças, bichadas nas Decadências, com o forte poder de sedução que leva Cellini a esculpir 'Perseu', quando podia esculpir um condottieri de seu tempo, e Coelho Neto a esboçar 'Artêmis', quando tanta artemísia da cidade e do sertão anda ignorada a pedir pintura.

A poesia, neste nosso recanto do mundo onde a virgindade da terra induz uma arte autóctone sem placentas no acervo clássico, não se forra de tecer fiorituras farfalhar variações sobre os velhos temas gizados na Grécia.

Tão grande foi a infiltração mundial grega, que ainda hoje a percebemos a palpitar viva na linguagem diária, e até no ramo mais pessoal da vibração emotiva - 0 amor. Neste momento, como sempre, vai pelo país, de Pelotas a Macapá, um intenso murmúrio de amor, chocalhado em sonetos, serenatas, cochicos. E d'envolta em luar e choro de violão, garatujadas em papel cor de rosa, amelaçadas em falinhas trêmulas regiram incessantemente as velhas gazuas gregas abridoras de coração femininos.

Desenvolve-se um malabarismo intenso de setas de Cupido, sorrisos de Cloé, néctares, ambrosias, musas, Leandros ansiosos por morrer ao pé de Heros, tudo aromatizado com florinhas de malva, enfeitado com mechas de cabelo atadas de fitinhas verdes e, para maior dose de tom local, sabiás, graúnas, iracemas - a fauna e flora inteira da palheta de Alencar.

Não há palerma, por mais canhesto em exalar as comichões do coração, que arranhando num cineminha pelas olhadelas escorridas duns dezessete anos de saia, não chimpe em carta rósea três metáforas, em duas das quais, pelo menos, não figure um helenismo clássico.

São meras imagens hoje, de curso forçado, como moedas de níquel para o troco miúdo do sentimento; remontadas à origem, todas imbricam numa lenda grega.

No ubertoso alfobre se geraram pela ação lenta do polipeiro em torno dum ponto de pega inicial.

Do mesmo modo que no polipeiro, pelo acamar dos exsudatos calcários, se vão erguendo no oceano grandes ilhas de coral, assim os exsudatos poéticos da imaginação coletiva se vão consolidando nas grandes lendas da humanidade - catedrais de Sonho que se chamam Olimpo ou Neiebelungen.

Seu autor é sempre vago 'Nemo', o mesmo vago arquiteto das catedrais góticas.

O povo, na ingênua simpleza da inconsciência, cria, o artista 'estiliza' - e por fim o sábio alemão as aquartela na disciplina de um sistema, dentro de um regimento de tomos. 
E desfeitas em mil bocados, sob forma de imagens, dão as lendas volta ao mundo para marchetaria poética da emoção, tal qual a árvore de coral s dissemina por toda a terra, quebrada em pedacinhos, para ornamento de braços, dedos e lobos de orelha.

O 'lendário' grego diz bem claro do povo que o concebeu. É bem filho dos marinheiros que borboleteavam de ilha em ilha pelo Mediterrâneo, ao cair da noite metiam a nave em seco e dormiam descuidosos sob o tremelicar das estrelas, sonhando incomparáveis sonhos.

A saúde dos homens, a formosura das mulheres, a lenidade do clima, o azul do céu, a vida livre e movimentada, criaram o ritmo daquela beleza - inexcedida na escultura e no sonho.

Entretanto, nem todos os sonhos se afinam pelos mansos cânones da serenidade. Há o pesadelo. E para o norte, em região polar à grega, sonhos agitados deram origem a outro 'lendário' formidável.

Os rios da Germânia não deslizavam amáveis como o Escamandro, mas rugidores como o Reno; as árvores não se reuniam em bosques arcádicos, como assembleias de epicuristas vegetais - mas em negras massas de carvalheiras milenárias, cujo vulto assombrava as próprias legiões romanas. E muita sombra, muito contraste violento de claro e escuro. E pântanos insidiosos, e feras e perigosos.

Os homens louros, senhores da terra, eram espadaúdos gigantes que as mães criavam ao relento, nus, para enrijá-los desde tenros anos ao léu das invernias ásperas. fantásticos.

Em guerra permanente de tribo com tribo, nos intervalos sonhavam pesadelos

O deus daqueles nórdicos não mostrava o bom humor e o bom tom de Júpiter, em vez de néctar, bebia sangue humano; não desceria à terra disfarçado em touro para raptar Europa, senão para mastigá-la, crua, com maxilas de tigre. Odin lembra um Marte a quem faltaram no seu os beijos de Vênus e o convívio amável de deuses galantes e galantíssimas deusas”. [p. 105-109]

\section{LOBATO, Monteiro. Negrinha. 3 ed. São Paulo: Brasiliense, 1950 (1920).}

\section{“A facada imortal” (1942)}

“Indalício racionalizava a 'mordedura' ao ponto da sublimação. Citava filósofos gregos. Mobilizava músicos de fama”. [p.161]

\section{“Marabá” (1923)}

"Verdade, Verdade!... Que musa tirânica! Como faz mal aos romancistas - e como os força a ter talento!

Foram-se as receitas, os figurinhos. Cada qual faça como entender, contanto que não discrepe do veritas super omnia, latim que em arte significa mentir com verossimilhança. [...]

Mas é mulher. Adivinha de instinto que as flores fê-las. Deus para a mulher, e colhe-as, e tece-as em guirlandas, e com elas enfeita os cabelos e o colo e a cintura. E assim, todas flores, mira-se no espelho das águas e sorri. E porque sorri, logo salta, alegre, e dança. E porque dança, anima as selvas da luz maravilhosa que os helenos ensinaram ao mundo. 
Súbito, um rumor fá-la estacar. A filha de Dionísio se apaga e surge Diana. Ei-la de arco em punho, em louca desabalada, na pista do cervo incauto que lhe interrompeu a bela improvisação coreográfica. [...]

- Iara?

No primeiro momento o medo sobressaltou-o - mas o sangue de Anhembira reagiu em suas veias, e não seria o filho do que guerreiro que jamais conheceu o medo quem tremesse diante de mulher, Iara que fosse.

E Ipojuca imobilizou-se à margem do rio, em muda contemplação, até que a ninfa, percebendo-o, fugisse para o lado oposto, mais arisca do que a tabarana.

Ipojuca atravessou o rio e logo mergulhou na floresta, em sua perseguição.

Jamais as ninfas venceram a faunas na corrida. Foi assim na Grécia; seria assim sob o céu de Colombo. O filho do cacique alcançou-a. Seu braço de ferro enlaçou-a; as mãos potentes quebraram-lhe a resistência e dobraram-lhe a cabeça loura para o beijo de núpcias.

Mas a virgem vencida abriu para o macho vitorioso os grandes olhos azuis e, encarando-o a fito, murmurou a tremenda palavra que afasta:

- Sou marabá!” [p.216-228]

\section{LOBATO, Monteiro. Onda Verde. São Paulo: Globo, 2008 (1921).}

\section{“A onda verde"}

“O café é uma epopeia. Quando nossa literatura largar o chazinho que beberica no Alvear e compreender a sua verdadeira missão, a epopeia, a tragédia, o drama e a comédia do café serão os grandes temas de quantos sentirem em si a fagulha divina." [p.21]

$$
\text { “O 'grilo"” }
$$

“Ao chegar neste ponto, o escrevente do cartório, que tirava a cópia, sofre uma alucinação ótica e escreve 'vinte e duas léguas' onde estavam 'duas'. Mesmo fora das bebedeiras é comum esta visão dupla das coisas, que há de ter em medicina um nome grego. Concluída a cópia, vai ela ao juiz para os sacramentos. Juiz, promotor e coletor subscrevem-na, depois de lançados o ‘conferido e concertado' do estilo. Mas nenhum deles realmente conferiu nem concertou coisa nenhuma, de acordo com a mais louvável das praxes, porque é preciso ter confiança no escrivão, que diabo! [...] E lá, entre grades [o advogado], antes de meditar Sílvio Pellico e Dostoievsk, sente na cabeça o famoso estalo de Arquimedes:

- Heureca!...

Lembra-se de que em mãos de um amigo existe cópia conferida e concertada, e compromete-se a dá-la em troca do original que o saci (evidentemente o saci!...) lhe furtara da gaveta.” [p.29]

\section{“A arte americana”}

“Os Estados Unidos eram acusados de não ter arte. E de fato, povo adolescente, a formar-se em terra nova com a fina flor eugênica das boas raças europeias, e, pois, o 
núcleo mais rico em valores que ainda surgiu sobre o planeta, era estranho que em matéria artística permanecesse aquém da caduca Europa.

A explicação do fenômeno temo-la hoje. As belas artes, filhas, uma da rêverie, qual a música; outra, da sensação visual como a pintura, outra, da álgebra, das proporções, como arquitetura; outra, da escolha e estilização da forma tátil, como a escultura; outra, da idealização vocabular, como as belas-letras: todas se condicionavam a épocas e povos com peculiaridades. Na Grécia de Péricles, a escultura; na Itália de Leão X, a pintura, na Alemanha do século XVIII, a música; na França, o teatro; na Inglaterra, a novelística.

Estas artes emigraram para os Estados Unidos já velhas, já 'rosas de três dias', tendo já dado de si o máximo e, pois, infletidas para decadência. Mas para nenhuma delas em especial propendia, morbidamente, o grande povo da América, visto que esse grupo humano não se desenvolve por unilateralidade, a guinar ora num rumo ora noutro, e sim marcha para frente num ímpeto de formação cerrada.

Fazia-se mister, para os Estados Unidos, uma arte nova, que comparticipasse de todas e fosse ao mesmo tempo um gigantesco negócio, capaz de atrair a atenção daquela coorte de pioneiros. E surgiu o cinema.

[...]

Senhor absoluto dos mercados, o cinema americano encontrou na formidável renda da indústria cinematográfica o mais possante estímulo para a arte cinematográfica. Uma arte qualquer só atinge o apogeu quando um caudal de ouro e glória lhe banha as raízes. Péricles, Leão X, Luís XIV...” [p.125-126]

\section{LOBATO, Monteiro. Mundo da Lua e Miscelânea. 2ed. São Paulo: Brasiliense, 1948 (1923).}

\section{Primeira Parte: Mundo da Lua}

\section{"Da ironia"}

"A ironia é a maldade dos revoltados, dos malfeitos, das criaturas tortas de alma ou corpo - Popes, Leopardis, Scarrons... É uma vingança ininterrupta que deflui como um fio d'água venenosa... e deliciosa para os que, também feios de alma e corpo, não podendo exercê-la, regalam-se no gozá-la. Os homens belos, perfeitos de alma e corpo, não ironizam. É que não vivem no perene estado de revolta que estila esse alcaloide grego - a eironeia.” [p.11-p.12]

\section{“Varão de Plutarco"}

"O visconde de Ouro Preto termina o seu protesto contra a violência da polícia numa frase cheia de orgulho: 'Não haverá façanha para ninguém em vencer-me, fraco que sou. Ainda não nasceu, porém aquele que consiga humilhar-me.’

Que retrato!” [p.25]

\section{“A tolice”}

"O Isauro, a quem mostrei uma coleção de gravuras antigas representando obras primas clássicas (o Apolo de Belvedere, a Vênus de Medicis, Niobe, Laocoonte) produziu este comentário encantador: 
- Muito livres...”[p.31]

\section{“A crosta"}

"A muralha que a idiossincrasia cristã interpôs entre os gregos e nós, rui, ou diafaniza-se. Lendo Aristófanes tenho a sensação de um homem sadio que estuda naturalmente uma natureza virgem, uma sociedade não estruturada, um homem limpo de alma, simples, fresco, não empastado com o fecalona de vinte séculos de catolicidade. Aristófanes e todos os mais.” [p. 48-49]

\section{“Arte”}

“A arte nasce quando o homem cessa de lutar contra o meio adverso. Nasce como florada consequente à completa evolução da planta. Na Grécia, a benignidade do clima e a amenidade da natureza não ofereciam resistência ao homem, e as forças que este, em caso contrário (caso da Índia, do Brasil, da Sibéria, por exemplo), despendera em reações contra o meio agressivo, convergiram para enseivar o instinto estético, dando origem à maravilhosa eclosão das artes clássicas.” [p.71]

\section{“A velhinha”}

“A minha boa velha lá do fim da rua contou-me nova história da sua cabra. Vim cheio de cabras na cabeça. Fui à Grécia ver a cabra de Júpiter, cheguei a Caxemira - e tive a visão dos jumentos de Pompeia.” [p.84]

\section{Segunda Parte: Fragmentos}

\section{“A arte”}

"A arte nasce quando o homem domina o meio adverso; como um luxo, como floração da planta após a vitória desta sobre todos os óbices opostos à sua desenvoltura. Na Grécia, a amenidade ambiente, não opondo resistências ao homem, permitiu que, em vez de dispersar suas forças na luta contra a natureza agressiva, ele as convergisse para a inflorescência.

Nós no Brasil ainda estamos a crescer, a enfolhar, a radicar. Por isso o que chamamos de arte não passa de simples reflexos de artes alheias. Arte como a grega em bloco, conglomerada, todas reunidas em torno dum mesmo tronco (um ideal racial) como vergônteas de igual pujança - tê-la-emos um dia, no ano 2.000 ou 2.500, quem o sabe? E tê-la-emos porque não há planta que não venha a flor. Se vem a rosas ou a flor de abóbora, já é outro caso.” [p.99]

\section{Terceira Parte: Miscelânea}

\section{“Traduções”}

“Toda a antiguidade Greco-romana ainda nos está fechada. Não temos a nossa tradução de Homero, de Sófocles, de Herótodo, de Plutarco, de Ésquilo. Como não temos Shakespeare, nem Goethe, nem Schiller, nem Molière, nem Rabelais, nem Ibsen. Faltanos quase tudo, e isso por causa da vida indigente que ainda é a nossa. Sem 
enriquecimento material, sem desenvolvimento econômico, um povo não pode enriquecer-se espiritualmente”. [p.129]

\section{“De São Paulo a Cuiabá”}

"De uma cidade a outra, por exemplo, há cem léguas; que dizer que há cem serpentes que o viajante tem de ir matando uma a uma até á derradeira. Ora, o trabalho é imenso. O viajante chega derreado, com o coranchim a arder, reclamando a berros semicúpios de salmoura. E o trágico é que as serpentes-léguas que ele matou renascem todas, logo que trata de voltar. Nova trabalheira de Hércules, nova matança das cem léguas. E, pois, como há de progredir uma terra onde o homem se vê forçado a consumir o melhor das suas energias físicas na matança de serpentes que perpetuamente renascem?

O problema de Mato Grosso se torna claríssimo: petróleo. Só o petróleo vence a légua. Que é uma légua para um automóvel em boa estrada? Três minutos. Que é uma légua para um avião? Um segundo. Aqueles heroicos patrícios de Cuiabá apenas montam guarda ao território, sitiados que se acham por milhões e milhões de léguas. Há dois séculos resistem nos redutos brotados dos acampamentos de garimpagem estabelecidos pelos bandeirantes, á espera de um milagre qualquer. Esse milagre só poderá vir sob forma de petróleo - o 'Flit' que mata as léguas. [p.239]

“O triste deste incidente das estradas de rodagem de São Paulo é a verificação de que elas têm ainda de ser 'pregadas', apesar de toda a vida da humanidade, sobretudo depois da conquista romana, não fazer outra coisa senão provar e reprovar, demonstrar e redemonstrar até ao infinito da exaustão, que o transporte é tudo, absolutamente tudo num país; e que, portanto, não há vida, nem civilização, nem riqueza, nem nada, sem caminhos facilmente trafegáveis, por onde as gentes e as mercadorias escoem.” [p.313]

\section{“Machado de Assis"}

"Muitas dessas flores vieram da Grécia antiga - e nenhuma da moderna. Outras nasceram em Roma. No marasmo medieval o clarão das fogueiras iluminou uma orquídea preciosa - Erasmo. A liberdade moderna fez que desabrochassem muitas. Essas flores, filhas do pensamento, penetram na história simbolizadas pelas poucas letras de um nome. Dizemos Homero, dizemos Horácio, dizemos François Villon iremos dizer Machado de Assis. Nomes. Nomes das orquídeas raras que floriram no caudal sem fim das 'marionettes qui font, font, font, trois petits tours et puis s'en vont'." [p.330]

“Que ideia, que lembrança, temos hoje dos milhões de criaturas que deram suas três voltinhas durante o grande século de Péricles?

No dia acima citado, de junho de 1839, nasceu no Rio de Janeiro a humílima criança que ia dar o pedaço de mundo chamado Brasil o maior nome da sua literatura, isto é, a mais bela orquídea de pensamento jamais desabrochada nesse setor das Américas.”[p.331] 
LOBATO, Monteiro. O Garimpeiro do Rio das Garças. 4 ed. São Paulo: Brasiliense, 1995 (1924).

Não encontramos referências à Grécia.

LOBATO, Monteiro. O Presidente Negro. 1ed. São Paulo: Globo, 2008 (1926).

"De tudo quanto a jovem disse só me ficou claro no espírito a história dos passarinhos do pomar. Até ali pareceu-me uma criatura tal as outras, mas depois do 'corte anatômico' tudo se multiplicou e passei a vê-la qual um misterioso ídolo de divindade dupla, misto de Afrodite e Minerva”. [p.46]

“- Deixe Aristóteles em paz. Estamos na determinação universal, e a vida, ou o universo, é para nós um momento consciente desta determinação”. [p.49]

“- Esse ódio, ou melhor, esse orgulho - respondeu Miss Jane, serena como se a própria Minerva falasse pela sua boca - foi a mais fecundas das profilaxias”. [p.92]

\section{“Capítulo XVI: O titã apresenta-se”}

\section{“Capítulo XXIII: A derrocada de um titã”}

LOBATO, Monteiro. Mrs. Slang e o Brasil. 2 ed. São Paulo: Brasiliense, 1948 (1927).

Não encontramos referências à Grécia.

LOBATO, Monteiro. América. São Paulo: Globo, 2009 (1932).

“À moda dos gregos da antiguidade, que só filosofavam andando, o protagonista faz com seu interlocutor, a quem conhecera quando ambos moravam no Rio de Janeiro, longos passeios”. [p.19]

"George Washington e Lincoln - em que país dois homens subiram tanto? Já passaram de homens a semideuses. Pelo país inteiro não existem homens mais popularizados em praças, ruas, pontes, estátuas, memoriais”. [p.48]

"Ergue-se à margem do Potomac esse templo grego de mármore branco, a refletir suas 36 colunas jônicas (cada qual representando um estado da União como era ao templo da morte do sublime Abe) no espelho do grande lago que o defronta. As linhas são rigorosamente gregas. Henry Bacon, o arquiteto, achou - e todos concordaram com o achado - que só a majestade das linhas helênicas poderia afinar com a majestade das linhas morais daquele homem”. [p.49-50]

"Há o lago, um perfeito espelho retangular com moldura de grama, e cerejeiras, as quais na estação própria, japonizam de róseo o ambiente. Depois, a escadaria imensa com o templo grego no alto. Meus olhos poucas coisas ainda viram que emanasse maior beleza pura. Não procurarei definir em que consiste a beleza pura. Falharam na tentativa 
filósofos e estetas da mais súbida acuidade. É sensação indefinível. Senti-a porém ali em toda plenitude”. [p.50]

“- Não o dizia eu? - cochichou-me Mister Slang ao ouvido, porque diante do semideus até a voz nos falha e só possível conversa em tom de murmúrio. - Só aqui sentimos Lincoln e só aqui se torna compreensível a força com que esse homem, hoje puro símbolo, domina 120 milhões de criaturas. Para mim Lincoln é apenas o signo da Força Moral. Este monumento, menos ao homem que ele foi, ao presidente, ao libertador dos escravos, homenageia em mármore a força das forças - a Força Moral”. [p.51]

“- E para que assegurar-lhes a sobrevivência? - adverti eu em tom de quem houvesse ingerido pela manhã uma omelete de leis espartanas preparadas na caçarola de Nietzsche”. [p.52]

“Um país se faz com homens e livros. [...] Nos livros está fixada toda a experiência humana. É por meio deles que os avanços do espírito se perpetuam. Um livro é uma ponta de fio que diz: 'Aqui parei; toma-me e continua, leitor'. 'Platão pensou até aqui; toma o fio do seu pensamento e continua, Spinoza'”. [p.60]

"Mais adiante, um vestíbulo com esculturas de Minerva na sua feição dual de deusa da Guerra (defensiva, note-se) e de deusa da Sabedoria”. [p.62]

“- Alegria... - murmurei, contente de vê-la afinal tomada em conta. E foi sorrindo que me dirigi para o Corredor Sul, onde vi os heróis gregos pintados por Mac Ewen - Páris na corte de Menelau; Teseu abandonando Ariadne adormecida; Prometeu prevenindo seu irmão contra a malícia de Pandora; Aquiles ao ser descoberto por Ulisses quando se disfarçou em rapariga; Minerva dando a Belerofonte o freio de Pégaso; Perseu com a cabeça da Górgona; Jasão mobilizando os argonautas para a conquista do tosão de ouro; Orfeu assassinado pelas Bacantes; o pobre Hércules segurando a roca de Ônfale...

- Hello, Mister Slang! - exclamei nesse ponto, arregalando os olhos. - Isto aqui está o perfeito símbolo da América. O home de cá, este Hércules, não faz outra coisa. Não acha a mulher americana uma perfeita Ônfale?” [p.63]

"Circundando a rotunda, oito enormes estátuas simbólicas, ladeadas dos bustos de bronze dos frequentadores de biblioteca que ficaram famosos na história humana pelas suas realizações. A Religião e, lado a lado, Moisés e São Paulo. Comércio - e Colombo e Fulton.

História - Herótodo e Gibbon. Arte - e Michelangelo e Beethoven. Filosofia - e

Platão e Bacon. Poesia - e Homero e Shakespeare. Lei - e Sólon e Kant. Ciência - e Newton e Henry”. [p.69-70]

"Custou arrancar-me dali. Tanta coisa ainda a ver, e as numerosas inscrições a ler, de Carlyle e Cícero e Bacon e Pope e Virgílio”. [p.70]

"Por que tanto sucesso? As razões de sempre, em matéria de arte. Verdade, sinceridade - talento. Aquilo não lhes sai dos miolos, como Minerva saiu da coxa de Júpiter. Estudam. Metem-se nos bairros dos negros, a observá-los, e cada dia pescam um novo traço psicológico, alguma nova expressão, dessas que quando reproduzidas 
numa obra d'arte provocam do espectador a consagração suprema desta frase universal: 'Mas é isso mesmo!'” [p.120-121]

"Estes bárbaros da América, apesar de filhos de europeus, fazem o mesmo que o vândalo fez com seu machado nos Antínuos, Apolos e Vênus de mármore dos gregos e foram essas machadadas que possibilitaram o Moisés de Michelangelo e certos sonhos de pedra de Rodin - marcha para a frente em matéria de representação escultural da emoção humana. Que é o jazz, senão o novo machado com que destroem o classicismo dos Fídias e Praxíteles da velha música europeia para dos escombros criar música maior? Da primeira vez que vi um noturno de Chopin sincopado, revoltei-me.

Veio-me depois a compreensão - e hoje o Chopin clássico me soa tão piegas em face da sua versão americana como o sobrado nosso em face do arranha-céu”. [p.128]

"Voltei ao escritório. A Vênus já havia se retirado. Tive portanto, de contentarme com rever o quadro rápido que se me desenhara na memória - a sua entrada, a sua saudação de cabeça e aquele The snow is falling de que jamais esquecerei o tom”. [p.190]

"No meio da ponte detivemo-nos em contemplação do quadro titânico. Titânico, sim, por pernóstico que pareça o adjetivo. Tudo que dali víamos dava muito mais ideia duma construção de titãs, os gigantes da fábula grega que superpunham montanhas para escalar o céu, do que obra do bipedezinho homem. Embaixo corria sereno o Hudson, àquela hora, como sempre, coalhado de embarcações em marcha rápida. Nunca deixei de impressionar-me com a pressa das embarcações que sulcam as águas de Nova York, tão contrastantes com a preguiça e lentidão clássica dos veículos marinhos”. [p.238]

“- O grande Pã morreu!... - exclamei recordando a voz da Grécia. Mister Slang prosseguiu comentando-a:

- Sim, foi a voz que o piloto Tamas ouviu certa noite no Mediterrâneo, seguido dum coro lamentoso de ecos. Morrera com o deus Pã o mundo antigo. John Dewey põese qual moderno Tamas”. [p.244]

\section{LOBATO, Monteiro. Na Antevéspera. São Paulo: Brasiliense, 1946 (1933).}

\section{“Fala Jove”}

"E o oceano, atônito, assistiu à completa devassa dos seus domínios - com grande escândalo de Netuno.

Pobre deus! Quando o 'Deutschland' operou o maravilhoso mergulho transatlântico que o trouxe de Kiel a New York, Netuno lançou aos sargaços o tridente, exclamando num sincero grito d'alma:

- 'Não sou mais deus de coisa nenhuma. Deus é esse piolho da terra que inventa máquinas e se ri dos meus vagalhões, zomba dos meus ventos, fulmina minhas baleias e põe-me assim, no fim da vida, um miserável rei de opereta... Já destronou Cibele, a deusa da terra, já destronou Urano, o deus do céu. Até Júpiter, o deus dos deuses, onde lá vai! Só resta Vênus...’

Também Urano a princípio sorrira, quando, quando viu Gusmão lançar para os seus domínios a frágil passarola, vítima dum beiral de telhado. Sorriu ainda, desta feita amarelamente, quando Montgolfier ergueu bem alto suas esferas de ar aquecido. 
-'Vence a altura, murmurou consigo o deus, mas obedece aos meus ventos. Voará como a palha, mas jamais como as aves’.

Mas quando Urano viu Santos Dumont singrar o espaço num charuto, não paina que o vento leva mas ave firme na diretriz escolhida, o sorriso gelou-se-lhe nos lábios; e pela espinha veneranda lhe correu o arrepio de Napoleão em Waterloo, ao dar com Blucher no ponto em que devia aparecer Grouchy.

E o deus dos céus fez o testamento e as malas, e se foi para o Asilo dos Deuses Inválidos, jogar o gamão da aposentadoria com Netuno, Jove e outros que já achavam lá.

De passagem pelo Cáucaso, Urano objurgou o encadeado Prometeu:

-'Vê tua obra, miserável! Com o fogo que nos roubaste e lhe deste, a miserável vérmina da terra nos destronou um a um’.

Desse refúgio merencório os velhos deuses assistem hoje ao voo de Ramon Franco e trocam impressões.

-'Vem ele de Paris ao Prata em horas', comenta Urano, 'e neste andar os homens acabarão vencendo essa distância em minutos... Riem-se dos nossos éolos tão temidos, ganham das nossas águias no elance, varam a sorrir nossos nevoeiros, escravizam e transformam em moços de recados os invisíveis fluidos que tu, Jove, usavas tonitruantemente... Como isto dói, irmãos!'

Também Netuno falou, cofiando as imensas barbas verdes.

-'Rumo ao Prata... Saiu ontem de Palos e chegará amanhã ao destino... Esse trajeto só era possível outrora por mar, e nos bons tempos consumia meses, seis, oito, dez - e eram deliciosos meses para mim. Divertia-me despejando contra as caravelas a cornucópia inteira dos meus ventos, ora de feição, ora contrários, ora remoinhantes em trombas furiosas. Mas o meu supremo regalo era pô-las sem ventos de espécie nenhuma, ali nas proximidades da cinta equinoxial. Chamavam eles a isso 'calmarias' e nada os aterrorizava tanto. Ficavam parados no mar morto dois, três meses. Devoravam todas as bolachas de bordo. Consumiam as últimas reservas de água pútrida. E era de vê-los estorcerem-se nos horrores da fome e da sede, atirando-as à caça dos ratos e roendo como cães tudo quando era de couro. Em roda dos veleiros, meus esqualos, de dentuça arreganhada, riam-se de tanta miséria. E meus peixes-voadores alavam-se de cardumes aperitivos, bem à vista, mas fora do alcance dos famintos. E meu mar ondulava-lhes sob as embarcações, tantalizando os sedentos com a sua imensidão impotável. Mesmo assim me iludiam muitas vezes; transpunham a zona maldita do equador - forno sem brisa à volta do mundo estirado - e prosseguiam na rota às terras do ouro. Por mais que eu açulasse e baralhasse meus ventos, não consegui vencer todos eles; e se a incontáveis fiz tragar pelos meus escarcéus espumejantes, e a outros rachei de encontro aos penedos, inúmeros se salvaram e vieram plantar no mundo novo as sementes dessas metrópoles gigantescas, onde hoje lhes pulula a descendência vitoriosa...'

Aqui Netuno parou. Uma zoada no ar atraíra-lhe a atenção sonolenta. Ergueu os olhos envidrados e viu de asas espalmas [sic] o avejão de Ramon Franco em pleno voo.

Apesar dos preconceitos de casta e do ódio divino contra a vérmina da terra, o deus de barba verde sentiu n’alma um frêmito incoercível.

Olhou para Urano. Ess’outra múmia, a cair de séculos, também arregalava os olhos e fremia.

Era o entusiasmo, sentimento que pela vez primeira alcançava vibratibilizar o duro basalto que deve ser o peito de deuses caídos em caquexia senil.

Estavam assim, de nariz para o ar, quando atrás deles soou a voz de Jove, que se aproximara. 
- 'Amigos, tratemos de nos naturalizar homens. É o meio único que nos resta de voltarmos a ser deuses...”’ [p. 49-52]

\section{"Doloi stid"}

“Diz Agorio, em sua reportagem sobre a Rússia, que a nova organização da família permite o ressurgir legal do hetairismo grego, mas livre. A hetaira grega, erroneamente por aí confundida com a cortesã, não era livre, era uma escrava de grau superior. Glicéria foi parar às mãos de Filemon em troca de dez mil medidas de trigo, depois de haver coabitado com o poeta Menandro e, antes, com o pintor Pausias.

A hetaira russa não é uma escrava. Elege, escolhe, dispõe de si, é livre.

O hetairismo sempre existiu. No Japão é constituído pelo gueixismo. A gueixa, educada desde a infância para o amor em sua tríplice expressão, física, espiritual e sentimental, torna-se uma harpa erótica, ressonante, como a eólia, às menores brisas mas é de aluguel. Alugam-na a prazos fixos, como se fora um móvel de luxo.

Na França, que têm sido as Ninon de Lenclos, as Teroigne, as Maintenon, as Dubarry? Hetairas livres, negadas pela lei mas aceitas pelos costumes e, graças aos seus dons de espírito, tão famosas como essas gregas que enchem de encanto a antiguidade clássica - Aspásia, Laís, Frineia, Safo, para só citar as maiores. Agorio também cita as menores, como Timandra, amiga de Alcibíades; a escultural Arqueanasa, a boa musa de Platão; Corina, que descobriu aos olhos maravilhados de Píndaro o mistério da poesia; Herpilis, colaboradora de Aristóteles, Thais, amada de Alexandre e de Ptolomeu.

A hetaira há de reunir à beleza física a graça da cultura e a sutileza do espírito; só assim, completa, possui todos os requisitos para enliçar os homens superiores, os aedos, os artistas, os filósofos, tornando-se-lhes a companheira ideal.

Sempre existiu, já disse, aceita pelos costumes dos países de alta cultura, como a França, mas negada pela lei. Quer Agorio que na Rússia ressurja essa forma de companheirismo, mas desta vez legalmente.

É curiosa esta volta à Grécia depois de cada revolução social. Na revolução francesa, arrasado que foi o terreno, os novos esboços de construção iam à Grécia pedir modelos. Agora se dá o mesmo na Rússia. Esta reincidência prova como a Grécia era logicamente animal e natural.

O culto do nu, em vigorosa ressurreição na terra de Lenine, mostra a tendência de retorno à harmonia clássica. Diz o escritor argentino que por toda a parte se pode admirar a beleza ondulante do corpo humano. O gosto pelas emoções plásticas ganhou com rapidez a alma dos russos. Nas procissões públicas da juventude comunista, belas raparigas semi-desnudas se mesclam a efebos adolescentes, em encantadora promiscuidade. Confessa Agorio que é inolvidável o espetáculo. A linha flexível do corpo, envolto às vezes num torvelinho de véus rubros, dá à forma humana o mistério resplandecente das estátuas - vivificados no ritmo, na serenidade, na harmonia. Tais procissões, ao toque de músicas beliciosas, provocando-lhe a sensação de frisas gregas em movimento.

O exagero sobreveio. O gosto discreto do nu foi exagerado pelos 'doloi stid', sectários de fundo místico, que aliás tem proliferado menos na Rússia do que na Alemanha e nos países escandinavos.

Os primeiros membros desta seita que se atreveram a arrostar os preconceitos do povo russo foram um homem e uma mulher. Tomaram o bonde em Moscou sem outros trajes afora a estreita faixa vermelha onde se lia a inscrição - 'Doloi stid!' (Abaixo a vergonha!) a qual deu nome à seita. Foi um escândalo a princípio; depois vieram os sorrisos irônicos; por fim, a indiferença. 
Este fato foi em toda a Europa comentadíssimo de maneira desfavorável é à confederação dos soviets, não se levando em conta a origem alemã do doloistidismo. A seita destes fanáticos do nu tem seu ninho na Alemanha do norte, onde se constitui em colônias ao ar livre, nos bosques e nas margens dos rios. Sustentam que a roupa não só é antiestética, como ainda representa um constante atentado contra as leis da natureza. Homem e mulher nascem nus e nus devem viver.

A doutrina, diz, Agorio, cifra-se nisso, e qualquer estrangeiro que a aceite está em condições de filiar-se ao grupo. Só lhe exigem que varra do cérebro qualquer ideia pecaminosa, e jure conservar a pureza e inocência dum recém-nascido.

Feito isso, está apto a ser aceito num lar 'doloi stid'.

Entra. Surge um criado vestido de sua pele natural, que o ajuda a desnudar-se num vestiário e em seguida o introduz. Vão-se-lhe deparando quadros comezinhos da vida caseira, já seus conhecidos uns, outros inéditos graças à ausência de véus. Vê, por exemplo, brincarem as crianças como um bando de róseos Eros sem asas; e vê a clássica octogenária em sua poltrona tecendo peúgas. Peúgas na casa do nu? Sim. Os velhos estão isentos do adamismo, já que o aspecto do corpo humano em decadência não sugere ideias agradáveis.

Mas vêm agora ao seu encontro os donos da casa. Decepção. Em regra, embora não velhos, os donos da casa pecam pelo bambo das carnes ou pelo excesso de ventre. $\mathrm{E}$ já pensa o neófito em abjurar o doloistidismo, quando lhe aparecem os convidados. Tudo muda. São moças de formas estatuárias, que servem o chá com uma impassibilidade que espanta. Totalmente nuas, não; trazem no corpo coisa alguma nem podia deixar de ser assim: mostram nos lábios um pouco de carmim e nas unhas um róseo brilho artificial. Só...

Enfrentam os homens com absoluta serenidade. Dir-se-ia que trazem sobre os instintos aquela túnica de gelo que defende a castidade das banhistas públicas de Estocolmo.

A festa de recepção aos profanos em regra termina em baile - que é um desastre para o neófito em cujas veias corre o caprino sangue meridional. O comum é fugirem da sala por incapacidade de sustentar o juramento de inocência feito à estrada. Fogem, com imenso escândalo da paradisíaca assistência.

Nada é novidade no mundo. Aqui onde estamos, neste Rio cujas moças incidem em tantas censuras por mostrarem dois palmos de magros cambitos, os nossos avós tupinambás, donos da terra, viviam, ledos e cegos, em doce 'doloi stid', sem escândalo de ninguém.

Escândalo, e imenso, causou a chegada das cinco francesas vindas em 1558 com os navios de Bois Le Comte. Desembarcaram no forte de Coligny e dias depois se apresentaram na praia aos selvagens reunidos.

Ao vê-las, nossas vovós tupinambás, puras Evas antes da folha de vinha, levaram a mão aos olhos, arqui-escandalizadas:

- Mulheres vestidas! O mundo está perdido...

E benzeram-se com o maracá”. [p.73-77]

\section{“A moda futura”}

"É inegável que sobretudo depois da guerra se acentuou o começo do fim do governo representativo com três poderes autônomos, harmônicos e independentes, em moda ainda hoje. [...] 
Teremos regresso à crinolina de Napoleão III, com o nome mudado? Iremos buscar na Grécia a elegante tirania de Péricles? Virá o despotismo científico preconizado por Augusto Comte?” [p.151 - 153]

\section{"Krishnamurti”}

“As religiões nascem, crescem, esclerosam-se e morrem. É ridículo dizer isto, porque o próprio dos truísmos é se tornarem ridículos à força de evidência.

No entanto, tais truísmos ao nascerem provocam espanto e suscitam a mais cruel repulsa por parte das verdades de cabelos brancos, bem instaladas no oficialismo.

Os exemplos clássicos destas verdades que viram axiomas - ontem tímidas revoltosas, amanhã ferozes legalistas - são também ridículos. Tornaram-se ridículos à força de repetição, como acontece com as árias célebres, a 'La donna é mobile', por exemplo, que não perdeu a beleza mas cansou. Por isso deixo de citar o caso de Galileu às voltas com a polícia censora da época, firmíssima na verdade oficial do sol em giro à volta da terra.

Ora, pois, as religiões nascem; e como nascem, crescem - salvo quando nascem mortas. E, como crescem, atingem à maturidade, encruam na arteriosclerose do oficialismo e acabam agonizando às mãos de débeis religiões meninas. religião.

Erro pensar que é a ciência que mata uma religião. Só pode com ela, outra

Um período da história sobremodo interessante ao estudioso ocidental é o choque entre o cristianismo revoltoso e a legalidade pagã. Como abundam documentos que refletem a mentalidade greco-romana durante o longo período do choque, fácil se torna a apreensão do quadro.

Luciano de Samósata, por exemplo, denuncia em inúmeros diálogos como estava combalida a crença nos deuses olímpicos, um século antes de Cristo.

No 'Júpiter-Trágico’ esse Voltaire sírio tem laços de humor que lembram Mark Twain ou Bernard Shaw.

Travara-se na terra, em presença de numerosos assistentes, uma disputa entre o estoico Timócles e o epicurista Damis. O estoico defendia os deuses e Damis os negava. A disputa correu animadíssima e acabou interrompendo-se no meio para ser decidida no dia seguinte. Como, entretanto, a assistência se retirasse inclinada para Damis, o Olimpo assustou-se e Jove amarrou o burro. Vem Juno e indaga a causa da divina zanga. Teria acaso a Terra partejado novos gigantes que, à imitação dos Titãs, pretendessem escalar o céu?

-'Nada disso, coisa muito pior!' diz Júpiter. 'Estão lá embaixo os homens travados numa disputa de cujo desfecho depende a estabilidade do Olimpo. Se sai vencedor Damis, ai de nós!...’

O caso foi tido como dos mais sérios, e Jove resolveu convocar todos os deuses para que, 'debruçados na amplidão', acompanhassem os debates e torcessem pelo paladino da boa causa.

Assim se fez. Quando, porém, no dia seguinte os dois disputantes novamente se enfrentaram, um arrepio de pressentimento perpassou, gélido, pela espinha de Júpiter.

- 'Timócles parece-me trêmulo e perturbado. Vai estragar tudo. Já vi pela cara que não pode medir-se com Damis’.

E os deuses, em desespero de causa, põem-se a rezar pela vitória do campeão...

Começa a disputa. Júpiter manda que as Horas arredem umas nuvens que estão lhe tapando a vista. 
Trava-se o duelo de argumentos. Damis leva o outro à parede, 'dá-lhe na cabeça', como se diria hoje, e a assistência percebe que em poucos rounds estará Timócles nocaute.

Em certo ponto o estoico puxa um argumento espadagão: o fato de serem deístas todos os povos. Damis responde com o antropomorfismo e mais toda a bicharia ou natureza deificada: no Egito o boi, na Assíria a pomba, na Etiópia o dia, na Pérsia a água, na Pelúsia a cebola, em outros países o gato, o íbis, o cinocéfalo, o crocodilo, etc.

O deus Momo dá um aparte inquieto:

- 'Eu não disse, Júpiter, que os homens ainda acabam descobrindo isso?'

Júpiter, jeitoso, sossega-o:

- 'Tens razão, mas havemos de dar um arranjo no caso'.

A causa dos deuses era positivamente insustentável depois do rapto de Ganimedes e outros escândalos olímpicos; e Timócles, falto de argumentos, resolve fazer como os Timócles de todas as épocas: insultar o contendor e apedrejá-lo. E atiralhe em rosto um vocabulário muito nosso conhecido: infame, desenterrador de cadáveres, esterco imundo, filho das ervas, adúltero, corno, monstro de impudicícia, etc.

Os deuses regozijaram-se com a 'derrota' de Damis. Júpiter, entretanto, cisma:

- 'É, mas eu preferia ter do meu lado um Damis a dez mil apedrejadores...”’ [p.199-202]

\section{LOBATO, Monteiro. O Escândalo do Petróleo e do Ferro. 8ed. São Paulo: Brasiliense, 1956 (1936).}

\section{“O Escândalo do Petróleo”}

"Quem quisesse explorar o subsolo teria de entrar em uma das portas da ratoeira - e ai do desgraçado! Dante escreveu nas portas do inferno: Lasciate ogni speranza, voi ch'entrate. Quem entra no inferno da Lei de Minas, não escapa. Está perdido para sempre.

Com semelhante mundéu colocado como porta do subsolo, a triste sorte das primeiras vítimas desanimaria os outros - e ninguém, nunca mais, teria o topete de mexer num subsolo donde poderia jorrar a preciosa substancia fedorenta que nos custa meio milhão de contos por ano.

Lei labirinto de Creta. Lei cipó arranha-gato. Lei serpes de Laocoonte. Lei arapuca. Lei mundéu. Lei trapa. Lei gramaticida. Lei matapau. Lei rolha. Lei atentado de lesa-pátria, de lesa-direitos, de lesa-bom senso, de lesa-dignidade humana. Lei Fleury em suma.” [p. 13-14]

\section{“Ferro"}

"O dilema vai se tornando cruel: ou produzimos ferro para sermos um grande país, ou continuaremos colher de pau e pereceremos esmagados. A panela de barro da fábula sempre acabou rachada pela de ferro - seja a história contada por Esopo, La Fontaine, Trilussa ou pelo balanço de um guarda-livros internacional.” [p.266]

“Eis em poucas palavras, e sem linguagem técnica, o que é o processo Smith sobre o qual já se começa a falar entre nós. Negado a princípio, quadradamente, pelos nossos sábios da Grécia oficiais, dado como fantasia de um literato de letras tontas, já merece a atenção distante dos nossos paredros científicos - gente que nunca produziu 
uma grama [sic] de ferro em toda vida e sabe de siderúrgica o que consta nos livros clássicos - quer dizer, de livros com 30 anos, no mínimo, de atraso. Apesar da existência em Detroit, aberta a quem queira ver, de uma bateria de cinco fornos, com capacidade para 52 toneladas de ferro-esponja por dia - demonstração perfeitamente industrial, portanto; apesar duma fábrica em plena expansão na Índia, e de uma montagem em Toronto, e de várias em estudo em outros países, esses insignes mestres teimam em permanecer numa gravibunda ignorância. Ignoram, como o ocioso de Horácio vadiava - cum dignitate, solenes, majestosos.” [p.289-290]

\section{LOBATO, Monteiro. A Barca de Gleyre: Quarenta anos de correspondência literária. São Paulo: Cia Editora Nacional, 1944 (1944).}

“Perguntas quantas horas 'literatizo'. Nem um, meu caro, porque só leio o que me agrada e só quando estou com apetite. Não troco uma conversa com uma macaquinha (o sexo na mulher corrige a banalidade, no homem agrava-a, diz Machado) pela melhor tragédia de Eurípedes, porque por mais banal que seja a moça é sempre mais humana que um livro - e o humano quer o humano”. [S. Paulo, 10 jan. 1904.] p. 25

"Dizes que progredi no francês e é verdade: aprendi uma coisa. E sabes como? O Sílvio de Almeida, um dos juízes do concurso de contos, votou no meu, mas com uma advertência: 'Primeiro lugar, apesar do título'. Sabe qual era o título do meu conto? Gens ennuyeuses!.. Alguém lá da casa do Sílvio me deu a informação. Corei como romã e fui ao meu velho Sevène (Lembra-te? Calypso ne pouvait pas se consoler du départ d'Ulisses... - 'La rue du Savon' - 'Pend-toi, Crillon, nouns avons vaincu e tu n'y étais pas') e verifiquei que 'gens' em francês é macho e não fêmea, como pus no título. Voei à tipografia para fazer a correção. Era tarde...” [S. Paulo, 3 nov. 1904. p. 44]

“Tenho cá a tua opinião sobre Flaubert, Zola e a definição de arte deste - e como minha opinião precedeu à tua, estamos entendidos nesse ponto. Vamos a outro. Na penúltima carta dás como definição de arte do Taine a sua definição de obra d'arte, coisa muito diferente. Definição de arte foi coisa que o sensato e cautelosíssimo Taine teve o espírito de não tentar, para não dar a topada que todos os definidores vem dando desde a Grécia. Todas as definições de arte que conheço degeneram em noção, e isto pelo absurdo de aplicar o processo definitório, coisa puramente cientifica e lógica, ao fato mais incientífico e ilógico da humanidade - a Arte”. [Carta de Taubaté, 2 fev. 1905 p. 56-57]

“Quanto aos épicos, Dante, Milton, Homero, só com bons intérpretes, com Virgílios cicerônicos. O próprio Lusíadas nunca li inteiro. Cansa-me”. [Taubaté, 15 mar. 1906 p.77]

“Ânimo de te elogiar não é o que falta - mas falta matéria para elogio. Minha esperança é o que o anunciado 'Sebastião' seja a tão reclamada matéria. O elogio, concordo, é o mesmo néctar dos deuses do Olimpo. O paladar da nossa mente reclama-o como o paladar físico reclama sal na comida. Quando passamos algum tempo sem comer coisas doces ou salgadas, nosso organismo, ressentido, passa a reclamar sal e açúcar por meio do apetite. Assim, secas as nossas fontes - aquelas fontes donde corria com tanta prodigalidade todos os méis do Himeto, só nos ficaram duas: você para mim e eu para você”. [Taubaté, 1906. p. 78] 


\section{“Rangel:}

É provável que já me tenhas incluído entre os amigos de cruzinha na frente, e me supunhas lá pelo Lethes a disputar com Caronte. Erro. Estou mas é em Areias e a ler Homero. Só agora, neste interregno de 50 dias que me separam do casamento, e reentrado nesta calmaria absoluta de Areias, é que tive oportunidade e mood de enfrentar o incomparável Homero - e lavo a alma das feias impressões do mundo moderno com este desfile sem fim de criaturas 'belas como os deuses imortais'.

Que diferença de mundos! Na Grécia, a beleza; aqui a disformidade. Aquiles lá; Quasímodo aqui. Esteticamente, que desastre foi o cristianismo com a sua insistente cultura do feio!

Estive uns dias no Rio. Que contra-Grécia é o Rio! O mulatismo dizem que traz dessoramento do caráter. Dizem que a mestiçagem liquefaz essa cristalização racial que é o caráter e dá uns produtos instáveis. Isso no moral - e no físico que feiura! Num desfile, à tarde, pela horrível rua Marechal Floriano, da gente que volta para os subúrbios, perpassam todas as degenerescências, todas as formas e má formas humanas - todas, menos a normal. Os negros da África, caçados a tiro trazidos à força para a escravidão, vingaram-se do português da maneira mais terrível - amulatando-o e liquefazendo-o, dando aquela coisa residual que vem dos subúrbios pela manhã e reflui para os subúrbios à tarde. E como vão apinhados como sardinhas e há um desastre por dia, metade daquela gente não tem braço ou não tem uma perna, ou falta-lhes um dedo, ou mostram uma terrível cicatriz na cara. 'Que foi?' 'Desastre da Central'.

Como consertar essa gente? Como sermos gente, no concerto dos povos? Que problemas terríveis o pobre negro da África nos criou aqui, na sua inconsciente vingança!...

Talvez a salvação venha de S. Paulo e outras zonas que intensamente se injetam de sangue europeu. Os americanos salvaram-se da mestiçagem com a barreira do preconceito racial. Temos também aqui essa barreira, mas só em certas classes e certas zonas. No Rio não existe.

Há tempos assisti em Taubaté a uma cena muito ilustrativa do que é essa defesa na América do Norte. Um americano desceu do trem e foi ao restaurante Pereira comer qualquer coisa. Sentou-se e pediu. Nisto entra um guarda-freio de boné na orelha, gaforinha, e senta-se-lhe ao pé. O americano ergue-se de impulso, atira a cadeira e some-se no trem. O país equiparava-o ao guarda-freio, mas ele não aceitava o presente. Filosoficamente me parece horrível isto - mas certo do ponto de vista racial.

A razão do meu silêncio está no meu andejismo. Em janeiro fiz mais de 2 mil quilômetros de trem, cavalo e navio. Andei mais que Telêmaco e se não encontrei Ulisses foi apenas porque não o procurei. O melhor desses passeios foi uma saída fora da barra a bordo do 'Saturno', no dia da partida da esquadra americana. Primeiro vimola sair, do 'Saturno' parado perto da fortaleza de Villegaignon; depois fomos atrás por umas trinta milhas. Tivemos mar calmo, mar grosso, ventania e chuva - uma bela exibição de amostras.

E o 'avança' que houve a bordo, na hora do lanche? Coisa inconcebível. Toda aquela gente fora convidada, e claro que era como se chama aqui 'gente fina'. Na hora de comer comportam-se como cães famintos que se atiram contra um montão de bofes. O carioca ri-se e diz: 'É o avança'... Isso de educação coletiva, só a vejo na pobre gente da roça. Na 'gente fina' do Rio de Janeiro não existe nenhuma...

Sabe alguma tradução de Homero em português? Leio na de Lecomte”. 
Lobato. [Areias, 3 fev. 1908. p. 132-134]

"Este mês de fevereiro foi o meu mês de Homero. Li a Ilíada e a Odisseia. Estou recheado de formas gregas, bêbado de beleza apolínea. Maravilhoso cinema, Homero! Gostei muito mais da Odisseia. A Ilíada peca pelo inevitável monótono do tema - a guerra ou, antes, o combate. De começo a fim, gregos e troianos morrerem como insetos, enquanto lá no Olimpo os divinos pândegos puxaram os cordéis e intrigam. Diodemes, Ájax, Aquiles, Heitor, Sarpedon racham crânios, estripam ventres, fendem ombros, decepam cabeças, rompem escudos, tomados duma horrível bebedeira de sangue. Aquiles é uma beleza. Páris, outra, mas de outro gênero. Já na Odisseia o assunto é caleidoscópio e sempre empolgante. Lê-se tudo aquilo como um romance de Maupassant. Penélope é ótima. Ulisses, um divino pirata. A descida aos 'campos de asfódelos', deixa ver a origem da Divina Comédia.

Finda a leitura, pus-me a pensar no quanto Homero influenciou e influencia ainda hoje no pensamento ocidental. Na linguagem corrente, quanto Homero meu Deus! “Fulano é meu mentor”, 'o teu calcanhar de Aquiles', 'astuto como Ulisses', a ‘teia de Penélope', 'os encantamentos de Circe' 'entre Sila e Caribdes'.

Estou agora ás voltas com a Eneida - mas, pelo que já li, Virgílio está para Homero como o jornalista está para o escritor. [...]

Alternei aquarelas com Homero - e aqui seguem duas”. [Areias de 25 fev. 1908 p.134-135]

"Então o Bernardo, como você previa, vaza os seus queixumes na forminha clássica dos decassílabos? Não há escapar às influições de Calíope! Aposto que até você versejou às ocultas, Rangel! É coisa que em certa idade nos vem como as espinhas”. [Areias 1 jul. 1909 p.162]

"Não sei do Ricardo. Estará no Comércio de S. Paulo? Suspeitei-o, encontrando por acaso um número desse jornal em que vinham os clássicos e nunca assaz republicados Elefantes do Lecomte de Lisle da sua tradução e também o meu Gens ennuyeux, que entra assim na quarta edição em jornal. A mim não convidou para colaborar. Donde recebi convite foi da Tribuna de Santos, jornal cor de rosa que o Valdomiro Silveira dirige, e já mandei como pano de amostra uma coisa cruel contra o Hermes. Prometem pagar a colaboração logo que concluam lá umas reformas. É preciso que a literatura renda ao menos para o papel, a tinta e os selos. A primeira coisa paga que escrevi foram artigos sobre o Paraná, coisa de outiva. Renderam-me $10 \$ 000$ cada, uma assinatura da Revue Philosophique (33 francos), um Aristófanes completo e um belo canivete de madrepérola com saca-rolha. Não foi mau o negócio, e assim pilhássemos tão alta remuneração para tudo quanto produzimos”. [Areias 7 jul. 1909. p. 164-165]

“Aquilo lá é uma espécie de Olimpo da Língua, todo deuses e semideuses e deusa nenhuma. Não havia mulheres em matéria de língua antiga, Rangel, como ainda as há tão poucas hoje - a Júlia Lopes e quem mais?” [Carta de Areias, 15 set. 1909 p. 175]

"Vou ver se ataco o $n^{\circ} \ldots 3 \mathrm{O}$ teu $\mathrm{n}^{\circ} 4$ envergonhou-me e meteu-me em brios. Estou lendo Memories d'Outre Tombe, de Chateaubriand. Acabei o Albalat. Bom, mas de pouco valor para nós aqui. Discreteia sobre o estilo francês, e as coisas mudam quando em português. A parte referente ao estilo descritivo em Homero é ótima, e boa para nós. 
A conclusão que tirei do livro é que estilos não se fabricam, nem se ajustam por influxo de regras; são o que são, como o nariz das pessoas”. [Areias, 22 ago 1909 p. 178]

"Não concordo com a tua ideia de que todo crítico é um raté da literatura, porque a crítica é um ramo da literatura para qual certos sujeitos nascem com aptidões especiais. Olhe Taine, Sainte Beuve, Macaulay. Mas não deixa de ser certo que muitos críticos de segunda são literatos fracassados em outros gêneros. Sentem o prazer satânico de se suporem numa sacada, e lá de cima cuspirem no nos que passam pela rua. Prazer de juiz sentenciador - mas juiz que se nomeia a si próprio, não é nomeado pelo governo. Vingança, picuinha contra a Fatalidade. 'Falhei no meu poema? Pois esperem que vou desancar todos os poemas alheios'. O Albalat me parece dos tais. Aquilo de só admitir Homero, e ir filiando um estilo a outro até chegar ao de Homero, aquilo que parece ódio aos seus contemporâneos donos de estilo”. [Areias, 23 out. 1909. p.180]

"Estive ontem em Taubaté, onde a morte de uma parenta me fez herdar uma estatueta de Sèvres, Vênus nua com Eros bebê a querer alcançá-la - uma perfeição de beleza. Namoro-a todos os dias, e queria que a namorasse também. Esse Sèvres fez-me curioso da porcelana, e eis-me atolado nuns volumes eruditos”. [Carta de São Paulo, 20 maio 1910. p. 193]

"Por falar em galinha: estou de avicultor novo, um grego legítimo, contratado no Rio. É da ilha de Tinos e recém chegou do Acre. Para valorizar minhas Leghorns, dou-o como descendente bastardo de Homero. Purezinha vive a perguntar-lhe como é em grego isto e aquilo, e vai formando vocabulário. E como Lino me promete um lote de Orpingtons pretas da preciosa criação de luxo do Pedro de Toledo, Ministro da Agricultura, veja que produtos vou obter: aves aristocratas, ministeriais, de bom pedigree inglês e criadas por um neto de Homero - talvez um Átrida! Em tempo te mandarei um casal da maravilha, para que assombres Minas com o requinte”. [Fazenda, 7 fev. 1912. p. 221]

"Est modus in rebus - nem tanto a Cândido, nem tanto a Graça. Olha que se este nos autoriza ao 'fazer com que', ao 'cumprir com o dever' etc., é o caso de nos mudarmos para o bairro dos que não o autorizam. Há sempre uma alta nobreza no estilo que se põe nos moldes sintáticos dos grandes antigos, procurando tomar como regra o que neles for regra, e não se autorizando a constituir como regra geral uma exceção, uma cinca, um desleixo de Vieira ou Camilo, quando é certo que até Homero cochilava. Quanto ao meu erro do que 'se o pratica' é coisa tão soez e chata que escusava te alongares tanto na demonstração. Já o expungi. Não fujo à pecha de ignorante em gramática, e até proclamo essa ignorância. E na realidade guio-me pelo tato e o faro, pelo aspecto visual e auditivo da frase. Se algum período me toa falso, releio-o em voz alta para perceber onde desafina. E achada a corda bamba não a analiso, dispenso-me de saber que preceito gramatical foi ali ofendido: aperto a cravelha e afino a frase. O método não será dos melhores, mas é o meu. É o mau mas meu. Topete, hein?” [Fazenda, 23 out. 1915. p.272]

"Em matéria feminina, estou que a boa mulher, a certa para esposa, é a quituteira, mentalmente divorciada do marido e que lhe dá liberdade de esvoaçar. A monogamia não é agradável a Deus. O que Deus quer é a forma grega: esposas procriativas no gineceu e Aspásias no jardim”. [Fazenda, 30 mar. 1915 p.276] 
"A literatura francesa infeccionou-nos de tal maneira que é um trabalho de Hércules remover as suas sedimentações.” [Fazenda, 7 dez. 1915. p.294]

"Não conheço As Minas de Prata do velho Alencar, mas juro que também lá ele falsifica o homem - embelezando-o. Os índios de Alencar no Guarani são pescados na Ilíada de Homero”. [Fazenda,17 mar. 1916. p. 305]

"Eis, Rangel, o que é a minha vida na roça. Os dias voam. Não há tempo para nada e há tempo para tudo. A minha hora literária é hora furtada no meio do dia e à noite. Conteme lá agora um teu dia de juiz, ó coruja de Têmis!” [Fazenda, 30 abr. 1916 p.312]

"Na redação do Estado descobri uma gramática e abri-la furtivamente, como quem não quer; mas não tive ânimo de ir além. Medo da verdade. Qualquer coisa lá no fundo das tripas me bacorejava que aquilo não era silepse. Por fim resolvi consultar-te. Recebi a resposta e respirei. Renasci, como se houvesse recebido na testa um beijo de Minerva. Obrigado, generoso amigo”. [S. Paulo, 10 jan. 1917. p.343]

"Menotti mandou-me Ulisses. Bela edição conseguiu ele! Mas aqueles desenhos serão realmente do Menotti? Estou achando-o bom demais. Nalguns há traços de mestres. Evidentemente houve 'inspiração'. [...] Ontem li uma coisa de Almáquio Diniz, um pedaço de Bodas Negras. Não diz: 'Os grilos cricrilavam'; diz: 'Os orthopteros saltadores cricrilavam’. Também li Une Vie de Maupassant e, ataquei Le Lys Rouge e vários Camilos novos. A sova nos três Joaquins - o Teófilo Braga, o Silva Pinto e o Vasconcelos!... Homérica!” [Fazenda, 22 abr. 1917. p.348-349]

LOBATO, Monteiro. Prefácios e Entrevistas. 8 ed. São Paulo: Brasiliense, 1957 (1946).

\section{"Prefácio de Paraninfo na Formatura de Contadores de uma Escola de Comércio"}

“A moral manda que eu abrace comovido os futuros cotovelos furados e olhe carrancudo para a futura aristocracia dos vinte por cento. Os primeiros nada terão neste mundo, mas o céu os esperam de braços abertos, para cumulá-los de gostosas bemaventuranças. Já os segundos descerão às profundas do inferno, de braços dados aos seus honradíssimos patrões. E lá continuarão a ter de regalo, porque Plutão, o deus do Hades, também usa a escrita e sempre das preparadas.

Tendes, pois diante dos olhos dois caminhos, um cheio de abrolhos, outro macio e de todo flores. Mas não há [de] escolher com livre arbítrio. Quem escolhe é o temperamento de cada um, ou a terrível sogra chamada Injunção. E ao despedir-me de vocês eu aperto a mão dos oitenta por cento de futuros cotovelos furados. Para o restante vinte por cento, limito-me a piscar o olho esquerdo...” [p.114-115]

“Monteiro Lobato fala da Academia, dele mesmo e outros assuntos”164

“-Seus bichos, dos livros, é claro, são símbolos?

${ }^{164}$ Reportagem de Celestino Silveira. 
- Não surgiram com essa intenção, mas aos poucos os críticos os vão transformando em símbolos. Quindim, o rinoceronte, é a bruteza humanizada. Rabicó, o leitão, é o estômago. O Burro Falante é a filosofia de Epíteto. Pelo Natal deste ano vão aparecer mais 12 livrinhos novos: Os Doze Trabalhos de Hércules. Pedrinho, o visconde e a Emília afundam na Grécia Heroica para acompanhar Hércules, como Sancho o foi de D. Quixote; Pedrinho funcionará como o oficial de gabinete do herói; e Emília será a 'dadeira de ideias'. Em algumas das aventuras o grande herói salva-se em virtude das ideias de Emília ou da oportuna intervenção do escudeiro. Dessa penetração na Grécia antiga, Pedrinho traz para o Sítio de Dona Benta um personagem novo: o Meioameio, um jovem centauro, ou um potro de centauro, como diz Emília. Traz também o Cérbero, o cão de três cabeças e cauda de dragão que guardava a porta do inferno - mas Cérbero, adormecido por uma dose do pó de pirlimpimpim, não voltou mais a si, morreu e lá foi enterrado perto da horta, com um epitáfio da Emília...” [p.209-210]

LOBATO, Monteiro. Georgismo e o Comunismo. São Paulo: Brasiliense, 1948 (1948).

Não encontramos referências à Grécia.

MONTEIRO LOBATO. Literatura do Minarete. São Paulo: Brasiliense, 1959 (1959).

\section{“Os Lambe-Feras. Capítulo L”}

"Tudo em redor era estrondo e escuridão. Eu ouvia a água borbotar em gorgolões esbravejantes. E meu rico traste estava meio submerso, e eu com ele. Só a cabeça sobrenadava heroica e mais filosofante do que nunca. Eu recordava velhos filósofos. [...]

Horror! Eu ia sendo subitamente tragado por uma gelatina verde. Apesar das trevas envolventes, eu sentia o verdor daquela gelatina. Verde e afogueada - ardente como a túnica de Nesso. 'Pobre Hércules!' pensei comigo”. [p. 81]

\section{“Os Lambe-Feras. Capítulo LVIII”}

“Sim, que é alegre, porque dois capítulos tristes em seguida não é pouca coisa para um romance risonho como este. E é risonho o meu romance porque afinal de contas Heráclito era uma besta e Demóstenes tinha toda a razão. O nosso mundo com todos os seus males e podridões é risível, uma vez que não pode ser desinfetável”. [p.86]

\section{“Os Lambe-Feras. Capítulo LXXV”}

"E como aquilo lhes repontasse nos queixos com emocionante espontaneidade, os dois Lambe-feras juraram diante do Deus da Barba (Jeová? Júpiter Capitolino? Coisa curiosa! Nunca houve um deus imberbe ou barbeado...) que não procurariam as 
navalhas; e que se por acaso as achassem, não cometeriam nenhum barbicídio por todo um mês”. [p. 87]

\section{“Fragmento - Do Romance 'D. Edel””}

“Em vez desses Jeovás quasímodos que a suja humanidade tanto venera, Edel rende culto unicamente à Forma Impecável.

É a mulher no corpo, porém não como as mulheres que por aí existem, uns amontoados de carne grotescamente desproporcionais, pernas curtas, bundas enormes; é mulher como a Diana pagã que é para mim a obra-prima da Hélade - alta, esguia de formas, nervosa, seios pequeninos em vez de úberes como têm em geral as mulheres; seios improdutivos, criados unicamente para a Beleza, sem nenhum fim imediato de utilidade que dispute às vacas o ofício de mamadeiras”. [O Povo - Caçapava, 9 jul. 1903, p.98-99]

\section{“Tão Ingênua”}

"No dia em que Leonardo, já quarentão, ligou-se pelos sagrados laços do himeneu, com a tentadora Nisa, houve na vila muita gente prática que murmurou uma série de: hum! hum! muitíssimos significativos. Nisa era um prodígio de carnes entontecedoras, um perigo para o asceta mais rijo e o próprio Xenócrates talvez se sentisse envolvido no capitoso perfume - odor di femina - que Nisa sutilmente exalava. E o garbo do andar? com que sedução caminhava compondo um rastio harmonioso de movimentos sensuais e empolgantes! Ah, Nisa! ah, filha de Psique! Entretanto Nisa era a ingênua mais perfeita da vila; um anjinho, puro e inocente, de nenhum modo culpada do estranho ardor da volúpia com que a natureza a revestira. Tão ingênua que foi casarse justamente com o Leonardo, um quase velho; não via na união do homem com a mulher um meio de legalizar os mistérios de Afrodite; via uma união amiga com a de irmã com irmã”. [O Povo - Caçapava, 17 set. 1903, p. 135]

\section{“Filosofias”}

“- Também sr. dr. - respondeu prazenteiro - sou devoto do Deus Baco. Cego que tal disseste! O Juiz prorrompeu em severas recriminações e o ameaçou de enxovia caso continuasse a desrespeitar o tribunal. Ser devoto, ali, de outro Deus que não a Deusa Fórmula! [...]

Citar uma poesia diante da lei! Falar em Baco diante de Têmis! Que negro horror!

A atmosfera enubla-se. Desenham-se rugas coléricas nas frontes jurídicas: Têmis carregava os sobrolhos, zangada. [...]

Um bode irreverente que pastava na rua dá um berro amoroso. O berro repercute pela sala. Têmis estremece. Não lhe bastava Baco, surge também Fauno. Maldita Hélade! [...]

Era impossível continuar. Depois de Baco, Fauno; depois de Fauno, Morfeu. Decididamente, a mitologia pagã voltava-se inteira contra a pobre Têmis. Era melhor liquidar aquilo depressa”. [De O Minarete - 6 jun. 1907. p. 314, 316]

\section{“Em Casa de Fídias”}


“- Por Afrodite! Aí está uma façanha tão difícil como um trabalho de Hércules por mãos de Tersito. Duvido que o consigas.

Isto dizia de Fídias escolhendo um cinzel dentre os cinzéis que em caixa de ébano um efebo lhe apresentava, e o dizia à mulher mais bela da época, à jônia formosíssima que naquele momento pousava para a figura de Nêmesis, no baixo-relevo de Helena e Lêda.

No grande relógio de sol a sombra do indicador marcara já o meio daquele dia de esplendores, todo azul e faiscações luminosas sobre a cândida florescência do mirtal copioso que aureolava de verde a branca vivenda do escultor, perfumando-a suavemente. Da alpendrada, onde Fídias trabalhava nos dias em que Aspásia era o modelo, a vista alcançava uma paisagem serena de horizontes calmos ao fundo e um derramado bando de filazinhas alvas que desciam, crescendo, pelos declives da Acrópole, até se fundirem nas magníficas vivendas de mármore circunjacentes à Ágora. E à esquerda do Júpiter Olímpico, quebrando a monocromia cegante, como um papagaio em meio dum bando de fuinhas brancas, avultava a mancha verde-escura do plácido retiro onde Tomilda se acolheu após o insucesso do seu amor perante o coração de Aspásia. (Este ambicionado coração era já todo de Péricles, se bem que inda às ocultas na penumbra de timidez que envolve um amor nascente.) Uma porta aberta junto à alpendrada deixava entreve a grande oficina - um caos de alvuras imortais, alvuras de gênio àquela hora obumbradas pela meia-sombra do aposento; e ali fora, bem batida de luz, também se via uma, repousando num soclo empoado de esquírolas: pedra magnífica, tirada das carreiras do Pentélico, sem um veio a lhe macular a nívea candidez e na qual um escopro firme já esboçara a atitude de três figuras que o tempo imortalizaria. Ao lado desse bloco, sentada numa espécie de grabato, a grega famosa inclinava o corpo em lânguida postura, a cabeça apoiada no fuste da coluna, e os olhos de deusa pousados na figura do artista, que sorria prestes a reencetar o cinzelamento do rosto da Nêmesis. O peplo nitente caía em pregas moles, escondendo a meio o seu corpo tão belo que por ele se modelavam às estátuas de Afrodite, e tão famoso que de Mileto a Elêusis não havia lábio heleno que, ao evocá-lo, se crispasse na ânsia de um beijo.

- Vai agora a minha Afrodite, disse Fídias, pensar um pensamento amável, para me reter nos lábios um ar leve de felicidade calma. Assim!

Aspásia evocara talvez, a figura do homem amado, porque o artista a viu cerrar lentamente as pálpebras enquanto lhe descia a pousar nos lábios uma como luminosa borboleta de graça - o rito sutil das calmas felicidades.

Fídias embebeu nela um olhar demorado e quente, menos de artista, talvez, que de amante. Depois, sacudindo a cabeça poderosa, como a espantar a mosca de um pensamento triste, suspirou, e volvendo à pedra, mordeu-a com o cinzel.

Esquírolas gizaram de branco o ar sossegado, e o ritmo do macete se fez ouvir, cadenciado e firme. Caiu na alpendrada um silêncio de sombra adormecida. Fora, o mormaço parado, com andorinhas riscando curvas no azul, punha irisações na aresta das coisas.

A vida ambiente concentrara-se no ofego leve do seio de Aspásia e no fulgor vivíssimo dos olhos de Fídias. Tudo mais, parado e morno. Era o momento do fiat instante supremo em que uma aura de vida transfiltra-se à pedra e vem construir uma alma debaixo de sua fria mudez. Cada golpe embute-lhe um átomo de vida. Fídias criava. Êmulo de Jove, era, naquele momento, deus.

A face de Nêmesis ia surgindo da pedra bruta em relevo claro, e da ponta do cinzel, que sobre ela dançava um minueto, um fio de vitalização defluía, ajeitando-se numa expressão magnífica de graça. $\mathrm{Na}$ comissura dos lábios o cinzel mordeu o 
mármore com vivacidade nervosa e parou. Estava quebrado o encanto. Fídias volvia a ser homem. Riu-se.

Após um momento de êxtase no qual amorosamente contemplou sua obra, atirou com o cinzel para a caixa e retomou assunto da vida.

Falavam de Sócrates, que concebera violenta paixão pelo famoso pupilo de Péricles, Alcibíades, do qual Aspásia prometera ao filósofo vencer a desdenhosa insensibilidade.

- No íntimo eu os aborreço a todos, a essas feias máquinas de argumentar. Repele-os o meu temperamento. Quero a Forma, a Eurritmia, a Serenidade da Beleza pura e na Sofística só vejo maranhas e dissonâncias. Detesto a Sócrates.

Aspásia, sem descerrar os olhos, sofismou:

- A beleza moral não é também uma forma da Harmonia? Só o concreto é possível de ritmo?

- Bravos! exclamou Fídias, zombeteiramente. Quando a nova Targélia nos abre um curso de filosofia?

Aspásia descerrou os olhos e riu-se, cristalinamente, enquanto Fídias prosseguia, volvendo ao assunto:

- Alcibíades, um Apolo adolescente, poderá amar um sátiro como o tal inovador? Tem harmonias recônditas, dizes, mas que importa se não traduz instantaneamente num soberbo equilíbrio de plástica? Não, Aspásia; apesar de conhecer a força da felonia duvido que consigas vencer a repugnância dessa esplêndida criança.

- Verás. Juro-te por Afrodite que o pupilo de Péricles cairá nos braços do meu filósofo! afirmou com ar felino a pagã maravilhosa.

Houve um silêncio. Fídias retomou o cinzel e voltou à pedra. Seus olhos iam do mármore à carne e da carne ao mármore, roubando as formas de Aspásia para fixá-las no calcário. A grega semicerrou de novo os olhos; parecia dormir, sempre com a mesma expressão de amor e de vaidade saciada a desabrochar nos lábios em rito sutil.

Nesse momento ergueu-se da praça um rumor de passos. Aspásia, desperta, volveu para baixo um olhar de pressentimento. Um grupo de arcontes seguia em direção à Ágora. Passavam lentamente. Súbito, o rosto de Aspásia fulgurou, e de sua boca escapou um nome pronunciado com tal doçura que foi para Fídias uma ducha de gelo: Péricles!...

- Péricles! murmurou também entre os dentes, com voz rancorosa o artista, atirando para o grupo um olhar vencido.

Péricles passava, no meio dos arcontes, esplendidamente belo na sua clâmide alva, caída em pregas perfeitas de correção e elegância.

Passava e, ao defrontar a vivenda do escultor, ergueu os olhos. Aspásia mandoulhes ao encontro os seus... Trocaram, num relâmpago, poemas de amor.

E seguiu. A pagã irradiava. Saltou do grabato e espreguiçou-se felinamente, risonha, a rever pelo corpo inteiro uma aleluia d'alma. Fídias deixou cair o cinzel e correu a mão pela testa. Viu-a ajeitar o cabelo; viu-a consertar o peplo. E viu-a partir com a alma cheia do outro deixando após si um vazio imenso...

Lançou um derradeiro olhar à Nêmesis e sumiu-se pela oficina a dentro, de cabeça baixa, sombrio e torvo.

Porque também a amava...”

[De O Minarete, em 12 maio 1904, p. 319-323]

Hélio Bruma ${ }^{165}$

${ }^{165}$ Pseudônimo utilizado por Monteiro Lobato em sua juventude. 


\section{“Duas dançarinas”}

[Felyne Verbist]

"Um a um os seus gestos, revivendo na coreografia a alma senhoril do cisne, denunciam o que há de Grécia nas duas rivais em duelo.” [p.326]

"Quê? Diz-se lá com palavras o que só vive - e só vive instantes fugidios de vida - pela música - ondulação do som, e pelo gesto - ondulação da atitude? Diz-se lá com palavras de chumbo o que é fugaz por essência e sutil como cambiantes e leve como plumas vitalizadas? E diz-se, é lá possível, a graça natural, espontânea, não aprendida em conservatórios, de uma Felyne, flor moça de carne, requinte supremo da civilização que prende a alma latina à germânica e, debruçada sobre os séculos, dá as mãos e cochicha com a terra de Péricles? a terra banhada de um sol sem manchas em que Terpsícore, descida do Olimpo, vinha às margens do Ilisso ensinar à juventude a arte do movimento harmônico, ponto de fusão de dois ritmos - música e escultura?” [p.329]

\section{[Carmem Lídia]}

“Quando uma criatura dança aos nossos olhos lucila a imagem da Grécia - esse momento apolíneo da Vida Humana, clarão que até hoje nos redoira com os raios duma luz extinta.

E lembra-nos o verso de Junqueiro.

Porque ai! A mocidade é como flor do lótus que em cem anos floresce apenas uma vez.

A Humanidade é também assim - planta que só floresce uma vez e que, ai de nós! já viu passar esse instante de misteriosa eclosão.

A flor de lótus, única em milênios de vida, eis a Grécia...

Que pétalas entreabriu! Frineia, Aspásia... Que pureza de linhas! Fídias, Ictino... Que harmonia! A coluna dórica, o culto de Afrodite, a amabilidade dos deuses e dos homens, o ritmo em tudo...

Hoje, o que há de belo neste histerismo cheirando a gasolina chamado civilização - avaria de mau caráter, suja da poeira negra do asfalto, com uma gama completa de Quasímodos em permanente crocitar sobre todos os poleiros - vem de lá. São reflexos mortiços do astro helênico.

Raios loucos, remanescentes atávicos da luz morta.

Os criadores da beleza - artistas, poetas, dançarinas: criaturas do atavismo, gregos póstumos, nascidos fora do seu tempo - cochilos sublimes da Natureza. Assim nasce, de raro em raro, num rebanho de ovelhas negras, uma, tresmalhada, branca de paina.

Carmem Lídia é um caso desses. Criança de Atenas, por estranha aberração desabrocha no Pátio dos Milagres deste povo feio e mazorro.

Ela dança como lá se dançava - por injunção de duma vis insita.

Seus gestos, sua vidinha de 13 anos, suas ideias, seus caprichos de menina, seu andar, sua estesia inconsciente em via de cristalização, tudo nela se coa através do instinto heleno de beleza. 
A eurritmia - a perfeição do equilíbrio - é seu modo normal de ser. Ouvi-la, vêla, é ter a sensação de que se nos defronta não uma criatura singular, porém uma época. E que época! A Grécia de Péricles...

Carmem não dança unicamente no teatro, nas horas de espetáculo ou nos momentos de estudo. Dança permanentemente. Seu modo de ser é dançar.

Nos atos mais familiares da vida não tem um gesto, uma atitude, um movimento que se não revele como beleza em ação. Beleza dinâmica - esta expressão bárbara nos acode se, ao recordar a vivacidade da sua figurinha, vem de par com ela a imagem duma impassível estátua de mármore - beleza estática.

Bárbaros que somos! Meter a pedanteria de mecânica como tinta expressiva duma sensação fugaz!... É a rata do moderno, é a tara do decante a entremostrar suas falhas.

Fiquemos aqui antes que venha à baila a química, a biologia e mais horrores da época. Não há mais simplicidade, essa outra florescência da Grécia, e sem simplicidade d'alma não há dizer nenhuma manifestação de Beleza. E Carmem Lídia é uma esplêndida manifestação de beleza - porque é a própria Eurritmia feita menina e moça. Detém-te, pois, ó pena contaminada!” [p.329-331]

\section{MONTEIRO LOBATO. Cartas Escolhidas. São Paulo: Brasiliense, 1959 (1959).}

“Acabo de ler a tua carta - bárbara como uma Ode de Carducci - fascinante de vibração, de fogo, de selvageria, semelhante a uma pedra duríssima que, malhada por Hércules desfaz-se num turbilhão de faíscas”.

[Carta dirigida a Lino Moreira, 1902 p.63 $1^{\circ}$ tomo]

"Para mim Nietzsche é o único homem que desde Aristóteles até hoje possui aliados elevados ao requinte da intensidade, o senso abrangendi, e o senso penetrandi”.

[Carta a Albino, provavelmente de 1905. p.79 $1^{\circ}$ tomo]

"Já conhece a fundo o inglês e ora estuda alemão e grego, grego!"

[Carta a Lino Moreira. 15 ago. 1906. p.89, $1^{\circ}$ tomo]

"Por aqui vai a saúde de sempre e o contentamento de decepar este ano umas 15 cabeças da grande hidra Dívida. Infelizmente esta hidra tem cabeças demais (conto cada uma a conto de réis) e algumas renascentes, de modo que não é tão cedo que decepo todas. [...]

Muita saudade tenho da temporada daí, que hoje um vento endiabrado, lembrando o teu noroeste, me recordou. Mas como jurei aos manes da hidra não me arredar pé destes sertões enquanto subsistir um cadáver, vou engabelando Purezinha com promessas, e ficando cá a decepar cabeças. Quando espostejar a derradeira, então irei passar uma estação na praia deitado na areia de papo a cima”. [Carta a Heitor. Buquira, 17 ago. 1916. p. 154-155, $1^{\circ}$ tomo]

"Seus livros da Bahia revelam-me mais que um escritor, que um romancista, um artista. Revelam-me uma força da natureza, uma espécie de harpa eólia que ressoa à passagem dos ventos dos dramas da miséria. Daí a especialíssima impressão que causam - única inconfundível e TRÁGICA. Trágica no sentido grego da palavra. Na planura da literatura brasileira, Jorge Amado vai ficar com um bloco súbito de 
montanha híspida, cheia de alcantis, de cavernas, de precipícios, de massas brutas da natureza”. [Carta a Jorge Amado, referindo-se a Mar Morto (1936). p.14. $2^{\circ}$ tomo]

"Vou mandar-te um livro, O Minotauro. Na pág. 43, linha sete, deve mudar o que está por isto: 'A escrava simpatizou-se com os meninos e levou-os..."”

[Carta a Regina Toledo Moreira, filha de Lino Moreira, em data, possivelmente de 1939. p. $44,2^{\circ}$ tomo]

"Escreva ao Neves sobre mais tradução e reclame o novo livro da Dupré e a História da Grécia. Ou fica para reclamá-los quando vier. O $1^{\circ}$ vol. da Grécia já está nas livrarias”.

[Carta a Gulnara. 3 abr. 1943. p 102-103. $2^{\circ}$ tomo]

"Ainda desta vez falhou minha ida para aí. Acumulou-se neste fim de ano trabalho de mais: 12 livrinhos novos, infantis: os Doze Trabalhos de Hércules, que estou acabando de fazer, à razão de um em três dias, a tempo de apanhar o Natal. E revisões, e o diabo. Só depois de tudo isso liquidado poderei ter o gosto de aceitar o amabilíssimo convite do amigo para uma quinzena no Prata, hospedado no Pavilhão da Imprensa. E me será muito útil esse descanso, porque o trabalho de escrever 12 livrinhos de 96 páginas em 36 dias está-me parecendo que é o Décimo Terceiro Trabalho de Hércules”.

[Carta a Antonio Annunziato, São Paulo, 31 ago. 1944. p.134, $2^{\circ}$ tomo]

"E eu, meu caro, estou atracado com a revisão duma coisa enorme: as OBRAS COMPLETAS DE MONTEIRO LOBATO. Consta de 30 volumes com mais de 300 pgs. em média, ou o total de 10.000 páginas ao todo. Abrange o que escrevi para adultos e o que fiz para as crianças. Tudo encadernadinho para vender em bloco por mil cruzeiros - como faz o Jackson com o 'Tesouro da Juventude' e o mais. Exploração do público, em suma. Ora, eu tenho de rever 3 provas de cada volume, e a primeira eu revejo duas vezes. Tenho pois de ler 4 vezes as provas de cada volume. Totalizando são 40 mil páginas lidas atentamente e por obrigação. Vê que trabalho de Hércules? Depois duma coisa assim, não acha você justíssimo que me dessem um prêmio Nobel por tour de force de revisão?”

[Carta enviada a Artur Coelho, S.P. 1 fev. 1946. p. 165-166, $2^{\circ}$ tomo]

"Escrevi este mês 20 livrinhos novos para um editor argentino, livrinhos de poucos textos e muito desenho colorido. Quer dizer que a galinha velha ainda põe ovos - mas ovos pequenos - como acontece com as galinhas de penas quando vão ficando caducas".

[Carta a Gulnara. (São Pequenas historietas que a Editorial Codex lançou em 1947. Livros de armar, na época novidade editorial. Eis alguns títulos: Uma Fada Moderna, A Lampreia, No Tempo de Nero, A Casa da Emília, O Centaurinho, A Contagem dos Sacis, etc.)”. [S. Paulo, 30 jul 1947. p. 227, $2^{\circ}$ tomo]

LOBATO, Monteiro. Conferências Artigos e Crônicas. São Paulo: Globo, 2010. (1959) 
“Inclui-se neste número o Nós de Guilherme de Almeida, já conhecido em Caçapava, por famosa conferência dita em anos anteriores. [...] E no assunto, na maneira, nas cambiantes, no ritmo, na rima, em tudo procura e consegue ser sempre ele próprio. Não ressaibam seus versos o marasmático parnasianismo greco-heridiano, inçado de mármores helenos, jerebas de Atenas, marafonas de Corinto, pedras velhas da Acrópole, vagabundos-filósofos da ágora, nem bichos reais ou fabulosos, centauros e elefantes, pégasos e rinocerontes. O amor que os sonetos descantam é um amor fino, delicado, cheio de maciezas civilizadas.” [p.64-65]

Mem Bugalho „"Paraíba” - Caçapava, setembro de 1917

\section{“O mais velho dos escultores: $O$ acaso"}

"Foi a forma de arte que além da hagiológica mais floriu na Idade Média e tanto deixou de si na pedra das catedrais. Pois a exposição de [Antonio] Korch nos evoca todo esse passado de morbidez lúgubre. Há ali réplicas de Memmling e coisas positivamente copiadas de Dürer. Nada que lembre a serenidade e a harmonia grega.” [p.103]

\section{LOBATO, Monteiro. Críticas e Outras Notas. São Paulo: Globo, 2009 (1965).}

\section{“Inquérito literário sul-americano”(1923)}

“Só aproxima a arte. É ela que faz da velha Grécia um povo sempre presente. Ésquilo, Aristófanes, Fídias, Homero - são eles os artistas, o segredo da eterna mocidade helênica. Suprimam-nos e a Grécia virará uma remota expressão histórica que nada mais nos dirá. França: qual o segredo da universal simpatia pela França, tamanha que nos tira olhos para lhe ver seus crimes? O eterno segredo, sua arte - a ação dos seus poetas, dos seus novelistas, dos Mussetes, dos Maupassant, dos Barbusses. Através deles o pensamento francês revoa e, fixado em livros, vai pelo mundo inteiro conversar com os espíritos estranhos e florir-lhes as horas de estudo e meditação. Eliminem-se de França estas andorinhas que emigram e vêm pousar em nossos cérebros, e a França passará a mera expressão geográfica, muda e cruel, antipática e hostil.” [p.100-101]

\section{“O salão de 1917”(1917)}

"Raimundo Cela é outro nome que aparece. Traz uma tela de vulto: Último diálogo de Sócrates. A mania de sair do presente compreensível e mergulhar em mundos mortos, como o grego, é uma balda velha da Escola, que não perceberá nunca o absurdo contido nisso, diante da moderna concepção da arte. Como pode um menino do Ceará, transplantado para o Rio, e que não é um helenólogo com cinquenta anos de estudo, como pode essa moderníssima e brasileiríssima criatura interpretar com sua alma virgem de filosofias uma cena do século de Péricles? Fará artificialmente puro, está claro, à custa de reminiscências visuais. E dos professores que lhe escolheram ou aconselharam tal tema haverá um conhecedor grego, afeito a confabular com a legião de sofistas e, em consequência desse convívio mental, capaz de ouvir e entender Sócrates? E de pôr decentemente em tela a dialogar? Não obstante Cela denuncia-se com boas 
qualidades de arranjador e boa técnica, sobretudo nas figuras secundárias, já que na principal deu cara de Elixir de Nogueira ao filósofo e planejou-o pesadamente.”[p.147148]

\section{“A exposição do Saci” (1917)}

"É um fauno grego com cabeça de menino africano e não um diabo. O outro gesso incide no mesmo juízo. É só. Minto. Há ainda o barro do Poá, do senhor Oliveira Filho, que não é escultor, mas compendiou em argila todos os característicos da sua concepção sacizesca... Tem um mérito: foi o primeiro Saci modelado no país que o almirante Álvares descobriu por acaso em 1500 e que os aliados redescobriram agora por negócio.”[p.159]

\section{“Quirós” (1921)}

“Quirós não é apenas o pintor máximo da Argentina; é também um grande pintor moderno. É desses privilegiados de gênio que criam algo nuevo e produzem obras de infinita beleza - da beleza que o é sempre, cada vez mais, da beleza que nunca sacia porque não é beleza de convenção, passageira como modas, e sim a eterna, a esplendente beleza da verdade.

Como certas obras nos fecundam o cérebro e entreabrem de brusco o sentido profundo de expressão tidas como verbalismo sonoro! 'A beleza é o esplendor da verdade'. Quereis penetrar no sentido desta faísca de Platão? Detende-vos dez minutos em face do Jogo de sol e, se em vosso cérebro não der o estalo do Padre Vieira, saí, correi a fazer-vos eleger vereador... de Itaoca.

Como corresponderá São Paulo à honra que lhe faz o grande artista? São Paulo tem crimes sérios no cartório da arte. Desconheceu Rollo, premiou o sapateiro Ximenes, anda a faillutar o Ipiranga. Mas acima desse São Paulo gafento, que faz Apolo ter nevralgias no Olimpo, há um São Paulo de escol, fino, medido, sutil, capaz de compreender Quirós e de reter aqui telas que valem tesouros. A Revista do Brasil o avisa da oportunidade, como avisa o São Paulo negociante de uma coisa muito séria (mas isto aqui ao ouvido, muito em segredo): o empate de capital em telas como $\mathrm{Na}$ rede, Canto do meu atelier, Hortênsias constitui melhor negócio do que a aquisição de marcos. A Alemanha pode falir - a beleza, nunca!” [p.160 - 161]

\section{“Poèmier” (1921)}

"O Brasil hospeda com as zumbaias da praxe o senhor Paul Fort, francês, 50 anos, casado, meião na altura e príncipe dos poetas por graça de Apolo.[...]

Vem assim Sua Alteza enriquecendo o regaço de Pomona abundantíssimos Fortpoèmes onde se revogam todas as leis clássicas da composição poética. Porque Fort inova, cria, rompe com o passado, e tão alto se alevanta que, ao lado dele, triste figura fazem o João Racine, o Alfredinho da George Sand, o Lecomte da Ilha, o Edmundo, o Chico Coppée e quantos mais versógrafos desde Homero vêm por aí contando nos dedos sílabas musicais.

É natural, entretanto, tamanha superioridade, visto que os outros torturavam os miolos no penoso trabalho de compor e Sua Alteza limita-se a sacudir os galhos. Os outros elaboravam e Sua Alteza aplica a mecânica vegetal de deiscência. Os outros 
pertenciam à fauna apolínea e Sua Alteza é híbrido, da fauna e da flora a um tempo, hommearbre, poèmier (solanum tuberosun, Linn.?), enfim.’[p.164-165]

\section{“Francisca Júlia”(1920)}

“As Esfinges e os Mármores levariam apenas uma pecha: a da monotonia da perfeição. Tudo é perfeito naquelas páginas, minuciosas, irritantemente perfeito. No acabamento total de cada peça, de cada soneto, se engasta a integração de cada imagem, de cada ideia ou pensamento. A serenidade de sua arte, voando alto, se detém a cada momento, ciosa das belezas que semeia. Não tem fugas de condor. Tem planar sereno da águia. [...]

Não se sente em Argonautas o pulsar de seu coração à aventura, entre os anseios do heroísmo e o vago temor do desconhecido? É impassível quem pede 'A áurea bênção dos céus e a proteção dos astros’? É dramático. Frio, não.’[p. 182-183]

\section{“A vitória de Ximenes” (1920)}

"Por entre essa fauna rasteira de cozinheiros de Apolo soerguem-se os verdadeiros artistas, como jequitibás em meio da nossa macega. Detentores duma alta e segura técnica posta a serviço duma sensibilidade de eleição, os artistas fazem coisa suprema que é criar.

Os outros copiam.

Tocados da centelha divina, os artistas pairam nas regiões mais altas da expressão estética e, inspirados, arrancam ao mármore formas de imortal beleza.

Os outros roem a pedra, como rato rói o queijo. Diante da obra do artista o homem para, extático, empolgado por um misterioso quid, que é o segredo perturbador da verdadeira obra d' arte.

Em face do outro o freguês, na rua, saca do bolso uma lira, regateia um Vênus de Médicis, compra-a por metade e vai para casa convicto de que foi roubado.”[p.219]

\section{LOBATO, Monteiro. Cartas de Amor. São Paulo: Globo, 2011 (1969).}

"Estou a ler Homero, na Odisseia. Vingo-me da chateza da vida areense passando o dia em plena Hélade, com Ulisses e Penélope e Mentor. Que grande coisa, a literatura! Sem ela minha vida aqui conduziria irremissivelmente ao suicídio. Aqui só casado e casado com uma Purezinha. [...]

Adeus, minha adorada Penélope! Aceita um abraço bem apertado do teu desolado Ulisses.”

[Areias de 30 jan. 1908. p. 167 - 168] 
- Obra infantil:

LOBATO, Monteiro. A menina do Narizinho Arrebitado. São Paulo: Monteiro Lobato \& Cia, 1920 (1920).

Não encontramos referências à Grécia.

\section{LOBATO, Monteiro. O saci. 31 ed. São Paulo: Brasiliense, 1978 (1921).}

"Pedrinho logo percebeu que qualquer animal montado pelo saci mudava de modos, ficando não só mais ligeiro que nunca e fogoso, como ainda com um senso de direção que parecia sobrenatural. Inúmeras vezes tinha cavalgado o pangaré e galopado nele; nunca, porém , o vira assim tão ardente e veloz. Era como se o Saci lhe comunicasse alguma força mágica, que não é própria dos cavalos. Tal foi a velocidade desenvolvida que Pedrinho não pode deixar de dizer:

- Mas parece o famoso Pégaso do que meu velho e lerdo pangaré! Estou estranhando isso...

- Não estranhe coisa nenhuma - aconselhou o saci. Tudo são mistérios que só eu sei e que não vale a pena explicar agora.” (p. 61)

LOBATO, Monteiro. Jeca Tatuzinho. 14 ed. São Paulo: Instituto “Medicamenta” Fontoura \& Serpe, 1946 (1924).

Não encontramos referências à Grécia.

LOBATO, Monteiro. Aventuras de Hans Staden. 1 ed. São Paulo: Globo, 2009 (1927).

“- Infelizmente é verdade, meu filho. Com este ou aquele disfarce de pretexto, o mais forte tem sempre razão e vai pilhando o mais fraco.

- É a fábula do lobo e do cordeiro... - lembrou a menina.

- Qual, cordeiro! - protestou Pedrinho.

- É a fábula do lobo forte e do lobo fraco, uma que me anda na cabeça.

- Bem pensado! - disse Dona Benta. - Essa fábula não foi escrita por Esopo, nem La Fontaine, mas devia ser a fábula número 1, porque é a que tem mais frequentemente aplicação na vida.” [p.20]

\section{LOBATO, Monteiro. Peter Pan. 21 ed. São Paulo: Brasiliense, 1978 (1930).}

“- Para você perguntar e eu ter ocasião de ensinar uma palavra nova que ninguém aqui sabe. Neste mundo, Pedrinho, precisamos conhecer a linguagem das gentes simples e também a linguagem dos pedantes, senão os pedantes nos embrulham. Você já aprendeu o que é cinegético e se em qualquer tempo algum sábio da Grécia quiser tapear você com um cinegético, em vez de abrir a boca como um bobo, você já pode dar uma risadinha de sabidão”. [p.49]. 
LOBATO, Monteiro. Reinações de Narizinho. 8ed. São Paulo: Brasiliense, 1957 (1931).

\section{“Esopo"}

"Quem será o bicho careta? Com certeza algum homem que estava tomando banho e perdeu as roupas - berrou Emília. Vem embrulhado na toalha.

O senhor La Fontaine explicou quem era.

- Estás enganada, bonequinha. Aquele homem é um famoso fabulista grego. Não vem embrulhado em nenhuma toalha, mas sim vestido à moda dos antigos gregos. Chama-se Esopo. Foi o primeiro que teve a ideia de escrever fábulas.

Esopo chegou saudou cortesmente o fabulista francês. Depois fez festa às crianças. Vendo Emília, admirou-se. falante?

- Oh, uma bonequinha também! Era o único ente que faltava nestas terras. É - É sim. Emília fala pelos cotovelos - respondeu Narizinho.

A admiração de Esopo foi grande, porque apesar de velho nunca tinha sabido de nenhuma boneca que falasse.

- É extraordinário! - disse ele. Bonecas vi muitas em Atenas, mas mudas. O mundo tem progredido, não resta dúvida. Como te chamas, bonequinha?

- Emília de Rabicó, sua criada.

- Lindo nome. E quem te ensinou a falar?

- Ninguém - respondeu Emília com todo o espevitamento. Nasci sabendo. Quando o doutor Caramujo me deu uma pílula tirada da barriga dum sapo, comecei a falar imediatamente.

- Emília fala muito bem - explicou Narizinho. Pena é que diga tanta tolice.

O grego sorriu com malícia.

- Nós, sábios, também não fazemos outra coisa - disse ele. Mas como dizemos nossas tolices com arte, o mundo se ilude e as julga alta sabedoria. Vamos, bonequinha, diga uma tolice para o velho Esopo ver.

Emília desapontou e torcendo a ponta do seu lencinho de chita - respondeu com muito propósito:

- Assim de encomenda, não sei...

Os dois fabulistas trocaram um olhar de inteligência, como quem diz 'Vê?' Em seguida ferraram uma discussão a respeito da origem das fábulas - e afastando-se dali, foram sentar-se numa pedra à beira do ribeirão.

Vendo-se a sós, os meninos começaram a planejar grandes aventuras.

- Eu quero ver um leão! Quero conhecer o leão da fábula! - disse Pedrinho.

- Eu quero ver aqueles dois pombinhos do apólogo tão bonito que vovó contou disse a menina.

- E eu quero pegar um tatu canastra - disse Emília.

Era a terceira vez que Emília falava em tatu canastra. Narizinho ficou intrigada.

- Que tatu canastra é esse que você tanto fala, Emília?

A boneca respondeu sem demora.

- É que a canastrinha que trago sempre comigo me dá muita canseira. Tenho de carregá-la no lombo do Visconde o tempo todo. Ora, se pego um tatu canastra, fico dona de uma canastra que anda por si mesma nos seus quatro pés. Não acham que é uma boa ideia?

- É a maior ideia que a senhora já teve até hoje, Marquesa! - exclamou o Visconde. 
O pobre sábio andava que mal podia consigo, de tanto carregar às costas uma tal canastrinha. Por isso não falou nem se meteu em coisa nenhuma durante todo o passeio. Não pôde nem sequer debater ciência com os dois fabulistas, seus colegas em sabedoria. Se houvesse um tatu canastra, que bom!

Peninha contou que na floresta havia muito mais bichos que ali - leões, macacos, ursos - todos os animais importantes. Em vista disso, para lá se encaminhou o bando, guiado pela pena de papagaio flutuante. Assim que entraram na floresta viram no topo de uma árvore seca um corvo de queijo no bico. Pedrinho muito sabido em fábulas, disse logo:

-Aposto que embaixo da árvore está uma raposa. Ela vai gabar a voz do corvo, dizendo que nenhum sabiá canta mais bonito que ele. $\mathrm{O}$ vaidoso acredita, fica todo ganjento, abre o bico para cantar e o queijo cai e a raposa pega o queijo e foge com ele, na risada. Já sei tudo. Não vale a pena pararmos para ver isso.

-Vale, sim! Contrariou a Emília. Podemos enganar a raposa e comer o queijo.

Narizinho fez cara de nojo.

- Que coragem Emília! Comer queijo que já andou em bico de corvo...

- Comer de mentira, boba! Só para ver o desapontamento da raposa.

Mas não pararam. Pedrinho achava que corvo e raposa era bichos sem importância, dos que não vale a pena. Queria feras de verdade.

- Onde mora o leão Peninha? - perguntou ele.

- Na montanha. Vai-se pelo caminho da casa da Menina do Leite.

- Bravos! - exclamou Narizinho. Vovó nos contou a história dessa coitadinha que foi ao mercado vender leite da sua vaca mocha, fazendo castelos do que havia de comprar com o dinheiro. De repente tropeçou, o pote veio ao chão e a coitada viu iremse por água abaixo, com o leite, todos os seus lindos sonhos. Desejo muito conhecê-la pessoalmente.

A floresta formava ali uma clareira, de modo que puderam avistar ao longe a fumacinha, depois a chaminé, depois o telhado, por fim a casa inteira de Laura, a Menina do Leite.

- Lá vem ela! gritou Emília.

De fato, num vestido de pintas vermelhas, Laura vinha vindo na direção deles, com um pote de leite na cabeça.

- Bom dia, Laura! - disse Narizinho ao defrontar a raparigota. Aonde vai tão requebrada e faceira?

- Ao mercado da vila próxima, vender este leite da minha vaca mocha. Vendo o leite e compro duas dúzias de ovos. Pretendo chocar os ovos e tirar duas dúzias de pintos. Cresço a pintalhada e obtenho doze galos e doze galinhas. Vendo os galos e conservo as galinhas para botarem ovos. A duzentos ovos cada um por ano, terei, deixe ver... e começou a fazer a conta de cabeça.

- Não estraga a sua cabecinha, Dona Laura - disse Emília. Temos aqui o Visconde que é um danado para contas. Visconde, arreia a canastra e faça a conta desta menina.

O embolorado sábio obedeceu. Arriou a canastrinha, enxugou o suor da testa e fez a conta na areia, com um pauzinho.

- Dois mil e quatrocentos ovos - declarou ele por fim.

- É isso mesmo - disse a Menina do Leite, que já tinha feito a conta de cabeça. Dois mil e quatrocentos ovos! Ponho tudo para chocar e consigo outras tantas aves. Vendo-as no mercado e compro dez porcos. Faço uma criação de porcos e compro cinquenta vacas. 
A boneca, que conhecia a fábula, estava de olho no pote para vê-lo cair. Era naquele ponto que o leite se derramava. Mas o pote não caiu e Laura continuou:

Faço uma grande criação de vacas. Depois vendo as vacas e compro uma casa e um automóvel. Fico morando na casa e vou passear na vila de automóvel. Lá encontro um lindo moço que se apaixona por mim. Caso-me com ele e vou morar na cidade.

Emília estava na maior aflição. A Menina do Leite já passara todos os pontos em que o pote cai. Já estava casada e morando na cidade. Continuando assim a fábula ia ficar completamente sem jeito. A boneca não pode conter-se por mais tempo. cabeça!

- Pare, senhorita, e derrube o pote de leite, senão a fábula fica sem pé nem

Laura deu uma gargalhada.

- Já se foi esse tempo, bonequinha! Isso me aconteceu uma vez, mas não acontece outra. Arranjei esta lata de metal, que fecha hermeticamente, para substituir o pote quebrado. Agora posso sonhar quantos castelos quiser, sem receio que o leite derrame e meus sonhos acabem em desilusões. Adeus meninada, adeus!

Foi um desapontamento geral.

- Não valeu a pena pararmos para ver só isso - disse Pedrinho. Vamos depressa à montanha. Talvez lá as fábulas sejam sempre as mesmas. Quero ver o leão.

Nisto avistaram a montanha onde estava a caverna do rei dos animais. Dali por diante tinham que ir com todas as cautelas, na ponta dos pés, para não despertar a atenção de alguma fera. Chegaram ao terreiro que havia em frente da caverna. Ossos de animais devorados e um cheiro de carniça mostravam que não houvera engano, era ali mesmo a caverna procurada.

- Sei duma fresta na rocha - disse Peninha, donde podemos ver o leão sem que ele nos veja. Sigam-me sem fazer o menor barulhinho.

Todos os seguiram, pé ante pé, como gatos. Subiram pela rocha e por fim alcançaram a tal fresta, que ficava bem no topo da caverna, em ponto que os bichos não podiam alcançar nem que pulassem. Dali os meninos veriam tudo sem o menor perigo. Cada qual se ajeitou como melhor pode, com um olho na fresta.

- Lá está ele! - disse Pedrinho, que foi o primeiro a ver. Lá está o Leão da Fábula no seu trono de ossos, rodeado de toda a corte. [p. 272-277]

\section{"Peninha não falha"}

"Cansada das aventuras do dia e ansiosa por voltar para casa, Narizinho desafiou atropeladamente, sem apear-se do burro, as principais peripécias do passeio.

- Quando estivermos juntos outra vez, contarei tudo mais direitinho. Agora não posso. Adeus senhor La Fontaine! Adeus, Senhor Esopo! Até um dia!

- Para onde vão com tanta pressa?

- Jantar! - gritou Pedrinho.

Senhor de La Fontaine - disse Emília, fique sabendo que gostamos muito de sua pessoa. Apareça lá no sítio para tomar um cafezinho coado na hora. O senhor também, Seu Esopo. Mas vá de paletó e calça, senão tia Nastácia se assusta. Não façam cerimônias. Dona Benta não se importa. Ela é muito boa...

Os fabulistas prometeram aparecer.

- Au revoir! - gritou de longe a menina.

- Au revoir! - repetiu o senhor de La Fontaine com um aceno na mão - e ficou por um tempo a segui-los com os olhos.

Quando o burro desapareceu numa nuvem de pó, lá bem longe o fabulista suspirou: 
- Felicidade, teu nome é juventude!...

Em seguida voltou a sentar-se na pedra, à beira do ribeirão, e retomou a conversa com Esopo no ponto em que os meninos haviam interrompido”. [p.284-285]

\section{LOBATO, Monteiro. Viagem ao Céu. 1 ed. São Paulo: Globo, 2008 (1932).}

“- Ah, meus filhos, eu até nem gosto de pensar no que os sábios têm sofrido pelos séculos afora... Aquela coitadinha da Hipácia, por exemplo...

- Quem era ela, vovó? - quis saber a menina.

- Hipácia foi uma sábia grega nascida em Alexandria no ano 370. Não só muito culta, como de grande beleza. O pai educou-a muito bem e depois mandou-a aperfeiçoar-se em Atenas, que era a Paris do mundo antigo. De volta a Alexandria, Hipácia abriu uma escola onde ensinava grandes ideias de Sócrates e Platão. Tornou-se queridíssima do povo, sobre o qual derramava ondas de sabedoria. Pois sabe o que aconteceu com a coitada?

- Casou-se e... - ia dizer Emília, mas Narizinho tampou-lhe a boca.

- Que foi, vovó?

- Mataram-na! Um grupo de capangas, instigados por um tal bispo Cirilo atacou-a na rua, matou-a e esquartejou. continuou:

Os quatro coraçõezinhos ali presentes pulsaram de indignação. Dona Benta

- E a Sócrates, que foi um dos maiores iluminadores da ignorância dos carneiros, os pastores da época obrigaram-no a beber cicuta, um veneno horrível.”[p.21]

“- Por que, vovó, deram o nome de Centauro àquelas? Que relação há entre elas e os monstros meio cavalos meio homens da mitologia grega?

Dona Benta assoprou.

- Ah, meu filho, os astrônomos, que são homens de muita imaginação, achavam que uma linha ligando todas as estrelas desse grupo lembra a forma de um centauro.

- Mas lembra realmente?

- Olhe e decida por si mesmo - e Dona Benta indicou as principais estrelas da constelação de centauro. Pedrinho ligou-as com uma linha imaginária e não viu formarse centauro nenhum.

- Estou vendo vovó, que os astrônomos possuem ainda mais imaginação do que a Emília...”[p.24]

“- E as outras constelações?

- Ah, meu filho, há tantas... E inúmeras designadas por mio de nome de animais, como as do Escorpião, do Leão, do Cavalo, do Carneiro, dos Peixes, do Cisne, da Lebre, da Hidra, do Corvo, do Peixe Voador, da Abelha, da Ave do Paraíso, da Girafa, da Raposa, do Lagarto, da Rena, do Gato... [...]

Há constelações de nomes ainda mais curiosos - continuou Dona Benta - como a da Coroa, da Lira, da Flecha, do Alta, da Balança, do Relógio, do Telescópio, da Oficina Tipográfica etc. E há as de nomes poético, como essa da Cabeleira de Berenice, a da Pomba de Noé, a dos Cães de Caça, a da Harpa de Jorge, a do Barril do Gravador, a do Escudo de Sobieski, a do Coração de Carlos II, a da Cabeça de Medusa, a do Homem Ajoelhado etc.”[p.25] 
“- Que graça! exclamou Emília. - E Dona Benta? Que idade teria Dona Benta se fosse lunática?

- Dois anos, e quatro meses, mas 'lunático' quer dizer 'maluco' e não o 'habitante da lua’! Os habitantes da Lua, chamavam-se ‘selenitas’!

- Por quê?

- Porque em grego o nome da lua é 'Selene’. Selenita é uma palavra derivada do grego.

Pedrinho quis saber das montanhas e mares da Lua, e contou que num livro de Flammarion vira um mapa cheio de nomes daqueles mares e montanhas. [...] Falou no Mar dos Humores, no Mar das Chuvas, no Mar das Nuvens, no Mar do Néctar...

- Esse eu quero conhecer! - berrou Emília - Tomar banho no Mar do Néctar deve ser batatal...”[p.41]

“- Há inúmera montanhas - disse ele - batizadas com o nome de astrônomos e sábios célebres. Há a Montanha de Fabrício, a de Clávio, a de Plínio, a de Platão, a de Aristóteles, a de Copérnico... Vovó diz que a Luz é o cemitério dos astrônomos. A Ciência os vai enterrado nestas montanhas daqui.” [p.42]

“- 'Que quer dizer telescópio, vovó?'

- 'Tele’ em grego é longe e ‘skopeo’ é eu examino. Telescópio quer dizer 'eu examino ao longe'.

- Que beleza o grego, hein, vovó? É batatal...” [p.57]

“- Vamos ficar sem cavalo, Emília! O cometa grande está atraindo o nosso...

- E que tem isso? foi a resposta da boneca - Se o cometa grande atrair o nosso, apenas mudaremos de cabalo. Em vez de montadas num cavalinhos, iremos devorar o éter num verdadeiro cavalão de Troia” [p.74]

\section{LOBATO, Monteiro. História do mundo para as crianças. 3 ed. São Paulo: Brasiliense, 1952 (1933).}

\section{“X - Os deuses gregos"}

"No dia seguinte dona Benta esqueceu dos judeus e pegou nos gregos.

- Também em terras banhadas pelo Mediterrâneo, disse ela, outro povo apareceu, de muita importância na história do mundo: os Helenos ou Gregos. Tinham o nome de helenos porque foi um homem chamado Heleno, de origem ariana, que se estabeleceu naquelas terras e formou o povo. Hélade, era o nome da terra dos helenos.

Começa-se a ouvir falar desta gente ali pelo ano 1.300 antes de Cristo, tempo em que os hebreus estavam deixando o Egito. Os gregos não tinham um deus único, como os judeus, nem adoravam astros, como os babilônicos. Possuíam doze deuses principais e um certo número de deuses menores, que moravam no Monte Olimpo, a mais alta montanha da Grécia. Lá viviam uma vida muito semelhante à dos homens, porque os deuses gregos eram humaníssimos, isto é, tinham o mesmo temperamento e as mesmas paixões das criaturas humanas. A única diferença era que, como deuses, podiam mais do que os homens. O alimento deles chamava-se ambrosia e sua bebida, néctar.

- Que gostoso devia ser! exclamou Pedrinho. E não se sabe hoje o que eram esse néctar e essa ambrosia, vovó?

(Para mim, a tal ambrosia era pamonha de milho verde, murmurou Emília ao ouvido do visconde). 
- Não, meu filho, respondeu dona Benta. Não se sabe hoje, nem se soube nunca. Se os deuses permitissem que os homens lhes desvendassem todos os segredos, os homens acabariam virando deuses. Por isso castigavam os abelhudos, como um tal Prometeu que furtou o fogo do céu para o dar aos homens. Como castigo, Zeus, o dono do fogo, amarrou o ladrão a uma montanha de nome Cáucaso, onde um abutre lhe vinha bicar o fígado todos os dias.

- Bicar só, vovó? Por que não o comia duma vez?

- Sim; o castigo era esse - um bicamento do fígado que durasse eternamente.

- Eternamente? Quer dizer que ele ainda está no Cáucaso?

Dona Benta riu-se.

- Não; meu filho. Aquele tremendo Hércules, cuja lenda você sabe, foi lá e libertou-o. Mas os deuses gregos eram os seguintes: Zeus, ou Júpiter, o pai de todos e o mais poderoso. Senta-se num trono com uma águia aos pés, tendo na mão o raio, isto é, um zigue-zague de fogo. Quando queria vingar-se de alguém, arremessava esse raio, seguido dum trovão - como um índio arremessa a lança. Depois vinha Hera, ou Juno, mulher de Zeus e a primeira das deusas; Juno trazia sempre consigo um pavão. Depois vinham os outros.

- Diga o nome de todos, vovó, pediu Narizinho.

- Havia Poseidon, ou Netuno, que era irmão de Zeus e governava os mares num carro puxado por uma parelha de cavalos marinhos, tendo na mão o tridente - enorme garfo de três pontas. Netuno provocava tempestades, ou fazia as tempestades cessarem com uma simples pancada de tridente nas ondas. Havia Hefestos ou Vulcano, o deus do fogo. Era um ferreiro manco, que trabalhava numa oficina dentro da Terra. A fumaça da sua forja saia pela cratera dos vulcões - que se chamaram assim por causa dele, Vulcano.

Havia Apolo, que era o mais belo de todos e governava a luz e a música. Todas as manhãs Apolo aparecia no horizonte guiando o carro do Sol e dava volta no céu para iluminar o mundo. Havia Artemis ou Diana, irmã gêmea de Apolo, deusa da Lua e das caçadas. Diana vivia de arco e flecha em punho, perseguindo os animais. Havia Ares ou Marte, o terrível deus da guerra, que só estava satisfeito quando via os homens a se matarem uns aos outros. Havia Hermes ou Mercúrio, o mensageiro dos deuses, o leva e traz. Tinha asas no capacete e usava uma vara mágica de paz, que posta entre duas pessoas em luta imediatamente as fazia amigas.

- Já vi um retrato de Mercúrio, disse Pedrinho, mas a vara mágica tinha duas cobras enroladas.

- Sim, isso foi duma vez em que topou duas cobras engalfinhadas e interpôs a vara mágica para as separar [sic]. Em vez de se separarem, as cobras enlearam-se na vara e nunca mais dali saíram. Chamava-se caduceu, essa vara mágica de Mercúrio.

- A senhora já falou de oito deuses. Faltam ainda quatro, vovó.

- Havia Atena ou Minerva, a deusa da sabedoria, que nasceu dum modo muito especial. Júpiter teve uma dor de cabeça horrível, que não passava com aspirina nenhuma. Desesperado, chamou Vulcano para que lhe rachasse a cabeça com um golpe de malho. Vulcano obedeceu; mas em vez de ficar a cabeça de Júpiter em papas, deixou escapar, armada de escudo e lança, a sua filha Minerva!

- Que beleza! exclamou a menina.

- Havia Afrodite ou Vênus, a deusa do amor. Vênus era a mais bela das deusas, como Apolo era o mais belo dos deuses. Nascera da espuma do mar e tinha um filhinho de nome Eros ou Cupido, habilíssimo em flechar corações com flechas invisíveis. Havia Vesta, a deusa do lar e da família. Havia Deméter ou Céres, deusa da agricultura. Havia Plutão... 
na dúzia.

- Pare, vovó! gritou Pedrinho. Com Céres já contei doze. Esse Plutão é demais

- Eram doze no Olimpo, explicou dona Benta, mas havia ainda este Plutão, irmão de Júpiter, que tomava conta do inferno. A dúzia era realmente de treze. Isto falando só dos graúdos, porque com deuses menores e semi-deuses eram mais. Lembrome das Três Parcas, das Três Graças, das Nove Musas. Só aqui temos quinze.

A religião grega nada tinha de semelhante à dos hebreus ou egípcios. Era alegre e poética. Em vez de adorarem os deuses, os gregos invocavam-nos sempre que tinham necessidade de auxílio. Também lhe faziam sacrifícios, isto é, ofertas de animais ou coisas. Matavam o pobre animal e o queimavam numa pira, ou altar, para que a fumaça fosse enternecer o nariz dos deuses no Olimpo. Durante esses sacrifícios prestavam atenção a tudo quanto se passasse em redor, afim de descobrirem algum indício de que 0 deus estava se agradando ou não. Esses indícios chamavam-se presságios. Um bando de aves que voasse no momento, um trovão que trovejasse, um raio que caísse - tudo eram presságios, bons ou maus, conforme a interpretação dada.

- E os oráculos, vovó? perguntou a menina. Tio Antonio disse outro dia que a senhora para ele era um oráculo.

- Pobre de mim! exclamou dona Benta com modéstia. Apenas sei um bocadinho mais que ele, porque sou mais velha. Que é oráculo? Vamos ver isso. Perto da cidade de Atenas, que era a principal da Grécia, erguia-se, nas encostas do monte Parnaso, uma cidadezinha de nome Delfos. Em seus arredores havia uma racha na montanha, donde escapava um gás, tido como hálito de Apolo. Esse gás deu origem à instituição do famoso Oráculo de Apolo em Delfos.

- Como era isso, vovó?

- Assim. Uma sacerdotisa, ou pitonisa, sentava-se numa trípode, ou banqueta de três pernas, colocada no mais forte do gás. Passado uns minutos, a ação do gás a fazia cair em estado de delírio. Era então consultada por um sacerdote, e suas respostas, em geral confusas ou sem sentido como as de todas as criaturas fora de si, eram interpretadas, valendo como resposta do próprio deus Apolo. Vinha gente de muito longe consultar o afamado Oráculo de Delfos, que na maior parte das vezes dizia as coisas de modo a tanto poder ser carne como peixe. Um rei, por exemplo, o consultou sobre o resultado da guerra declarada a outro rei. O oráculo respondeu: 'Um grande reino está prestes a cair.' O rei ficou na mesma. Que reino ia cair, o seu ou do inimigo?

- Bem espertinha a tal pitoniza! murmurou Pedrinho.” (p. 34-38)

\section{“XI - A guerra de Troia”}

“- As guerras, prosseguiu dona Benta, constituem os principais acontecimentos da vida dos povos. Com elas as nações nascem e morrem. A história dos gregos principia a ser conhecida com a guerra de Troia, que se deu cerca de mil e duzentos anos antes de Cristo, nos começos da Idade do Ferro. Há muito de lenda na história desta guerra, porque os gregos eram criaturas ricas de imaginação. Mas vale a pena ser contada. Querem ouvi-la, seja verdade ou não?

- Queremos! exclamaram todos.

- Pois ouçam lá, disse dona Benta. Houve uma vez uma grande festa entre os deuses do Olimpo, e estavam todos banqueteando-se quando uma deusa, que não fora convidada, resolveu vingar-se dum modo especial - lançando a mesa um pomo de ouro com estas palavras: 'A mais bela!'.

A deusa que teve esta lembrança era a deusa da briga, e não fora convidada justamente para que reinasse paz na festa. Pois com a ideia do pomo, a malvada 
conseguiu imediatamente despertar a vaidade de todas as deusas ali reunidas visto que cada qual se julgava a única merecedora da fruta.

O meio de resolver o caso foi mandar vir da Terra um pastor de nome Páris, que decidisse qual a mais bela. Imediatamente as deusas trataram de seduzir o juiz. Juno prometeu fazê-lo rei; Minerva prometeu dotá-lo de grande sabedoria e Vênus, a deusa da beleza, prometeu-lhe o amor da mulher mais bela do mundo.

Páris não era um simples pastor e sim filho de Príamo, o rei de Troia, uma cidade que ficava perto da Grécia, do outro lado do mar. Em menino fora abandonado numa montanha para morrer no dente dos lobos; mas um casal de pastores o salvou. Agora estava no Olimpo, como juiz desempatador num concurso de beleza.

- Por quem será que vai decidir-se? Eu aposto em Juno, disse Pedrinho.

- E eu em Minerva, disse Narizinho.

- E eu em Vênus, que é a mais esperta, berrou Emília.

- Emília ganhou! Disse dona Benta. Entre ser um rei ou um sábio, e ser marido da mulher mais bela do mundo, Páris não vacilou - e portanto entregou o pomo a Vênus. Essa sentença deu origem a uma série de calamidades, cujo desfecho foi a destruição de Troia. A mulher mais bela entre as mortais era Helena, que já estava casada com Menelau, rei de Esparta, uma das cidades da Grécia. Vênus aconselhou Páris a raptar Helena.

Páris foi a Esparta, onde Menelau o recebeu principescamente. Apesar disso fugiu de noite com Helena e atravessou o mar, de rumo a Troia.

Meneleu e todos os gregos, furiosíssimos com aquilo, preparam uma expedição contra a cidade de Troia, para se vingarem de Páris e arrecadarem a princesa fugitiva. Naquele tempo as cidades eram cercadas de muralhas, e como não houvesse canhões e nem pólvora, tornava-se difícil penetrar nelas. Os gregos sitiaram Troia durante dez anos, sem que nada conseguissem. Por fim, resolveram recorrer a um estratagema.

- Já sei, inventaram o cavalo de Troia!

- Isso mesmo. Construíram um enorme cavalo de madeira, que puseram junto aos muros, em seguida retiraram-se com armas e bagagens, dando todos os sinais de que desistiam de tomar a invencível Troia. Logo que os gregos desapareceram, os troianos abriram as portas e foram admirar o cavalo. Imediatamente surgiu a ideia de o recolherem dentro da cidade. Um sacerdote de nome Laocoonte opôs-se, alegando que o cavalo de nada adiantava na cidade, além de que podia ser um embuste. Os troianos, porém, que estavam ansiosos para ver o cavalo enfeitando como um troféu de guerra uma das suas praças, não lhe deram ouvidos. Logo depois Laocoonte com mais dois filhos foram enlaçados e asfixiados por duas enormes serpentes saídas do oceano. O povo viu nisso sinal de que até os deuses estavam danados com ele por não querer o cavalo dentro da cidade - e sem mais vacilações recolheram o animalão de pau. Para isso tiveram que derrubar um pedaço da muralha.

Tudo correu muito bem, mas a noite uma portinhola na barriga do cavalo se abriu e por ela começaram a sair soldados gregos dos melhores. Saíram e correram a tomar conta das portas. Ao tempo que isso acontecia, as forças gregas, que se haviam retirado, principiaram a voltar. Pela manhã atacaram a cidade, entraram pela brecha feita para dar passagem ao cavalo e trucidaram todos os seus defensores e habitantes. Depois lançaram fogo às casas e retiraram-se para a Grécia, levando consigo a fugitiva Helena.

- Agora compreendo a expressão - presente de gregos! Disse Pedrinho. Quer dizer presente de inimigo, presente de alguém que não merece confiança.

- De fato assim é, meu filho. Quem aceita um presente de gregos, está perdido. A história minuciosa da guerra entre gregos e troianos encontra-se em dois poemas de 
grande fama. Um deles chama-se Ilíada, nome que vem do segundo nome de Troia, Ilion. O outro chama-se Odisseia. Neste conta-se o que, depois de terminada a guerra, se passou com um dos heróis gregos, Ulisses ou Odisseu. Sabem qual foi o poeta que compôs estes poemas?

- Camões! gritou a burrinha da Emília.

- Homero, ensinou dona Benta. Homero era um rapsodo, quer dizer, um pobre diabo que andava pelas ruas cantando versos para viver, como fazem hoje os homens do realejo. Além do mais, cego, o coitado - e por isso nunca escreveu seus poemas. Foram escritos por outras pessoas que de tanto ouvi-los os guardaram de cor. Só depois da morte é que Homero ficou famoso. Nove cidades gregas passaram a disputar a honra de ter sido o berço do cego que em vida andava de porta em porta, declamando seus poemas em troca de esmolas.

- Coitado! exclamou Narizinho. Nem teve o gosto de saber que ia ficar célebre...

- Homero ficou mais que célebre - ficou celebérrimo, como também aconteceu a certo rei de Israel...

Dona Benta tomou fôlego e prosseguiu.’[p.39-42]

\section{“XIV - As leis de Esparta”}

“- Antes de falar em Cartago, vovó, fale dessa Esparta, para onde os gregos da guerra de Troia levaram a Helena fujona. Que era Esparta?

- Era uma cidade da Grécia de costumes bastante especiais. Escutem. Novecentos anos antes de Cristo, por lá apareceu um homem de nome Licurgo, que sonhou fazer de Esparta a mais poderosa cidade do mundo. Para isso saiu a viajar, correndo os países que pode para ver as causas da força de uns e da fraqueza de outros. Viu que os povos que só davam importância aos prazeres da vida eram fracos, ao passo que os que punham o trabalho acima de tudo e cumpriam os seus deveres, fossem agradáveis ou não, eram fortes.

Voltando a Esparta, começou Licurgo a organizar a vida dos espartanos conforme as lições que aprendeu. Fez um código de leis severíssimas, que pegava o espartaninho ao nascer e ia até o fim da vida a governá-lo com toda dureza. 'É de cedo que se torce o pepino', devia ser a divisa desse código. Se os recém-nascidos eram fracos, ou possuíam qualquer defeito físico, a lei mandava abandoná-los numa montanha, para que morressem. Licurgo não queria que houvesse um só aleijado de nascença em Esparta.

- Sistema de Tia Nastácia com os pintinhos, observou Emília. Ela torce o pescoço de todos que não prometem bons frangos.

- As mães ficavam com os filhos por pouco tempo. Aos sete anos tinham de pôlos numa escola de treinamento, onde permanecessem até aos dezesseis. O treinamento consistia na educação do corpo, de modo a fazer o rapaz um perfeito e fortíssimo soldado. Regime duro como vocês não imaginam! De vez em quando os rapazes entravam na chibata, não por haverem cometido alguma deslize, mas para acostumar o corpo ao sofrimento. E quem chorasse no castigo, ficava desmoralizado pelo resto da vida. Durante os exercícios todos tinham de conservar-se em forma, sem dar a menor mostra de cansaço, ainda que estivessem morrendo de fome, sono ou dor. Também os acostumavam a comer as piores comidas, a aguentar as piores sedes, e a andar sem agasalho nos piores dias de inverno. $\mathrm{E}$ assim por diante. Chamavam a isso disciplina espartana. 
- Tudo não prometo, disse Pedrinho, mas alguma coisa do que Licurgo mandava fazer hei de seguir - para ficar a criatura mais forte aqui das redondezas!

(Emília que fora proibida de falar em vista das muitas asneiras que andava dizendo, cochichou ao ouvido de visconde: 'Quero ver se ele fica tão forte como o Quindim'. ‘Que Quindim é esse?’ perguntou o visconde. 'O rinoceronte’, disse Emília. 'Não sabe que batizei o rinoceronte com esse nome?' E foi a partir daquele momento que o rinoceronte passou a ter um nomezinho tão mimoso).

- A vida dos espartanos, continuou dona Benta, era bem dura. Simplicidade na comida, ausência de conforto e supressão completa de tudo quanto fosse luxo. Isso os transformou num povo extremamente rijo. Eram ensinados até a falar com energia e economia, dizendo o máximo com o mínimo de palavras. Como se chama este modo seco de falar, Narizinho? Eu já ensinei.

- Lacônico, respondeu a menina.

- Muito bem. E donde vem tal palavra, Pedrinho? O menino engasgou.

- Vem justamente da Lacônia, a província da Grécia de que Esparta era cidade principal. Modo de falar lacônico quer dizer o mesmo que modo de falar espartano mas só a primeira expressão é usada. Certa vez um rei vizinho enviou aos espartanos uma carta ameaçadora dizendo que se eles não fizessem tal e tal coisa, ele rei marcharia com os seus exércitos e derruiria a cidade, escravizando toda a população. Os espartanos leram a carta e incontinente deram a resposta com uma só palavra: 'Se...'

- Bonito, vovó! exclamou o menino entusiasmado. Não pode haver nada melhor do que essa respostas lacônica. Se... Imaginem a cara do rei! Mas diga-me uma coisa, vovó: o sistema de Licurgo deu bom resultado?

- Deu e não deu, meu filho. Deu num ponto e não deu noutro. Licurgo errou cuidando mais dos músculos do que da cabeça, e apesar de todo aquele esforço Esparta nunca teve importância de Atenas, a cidade grega que lhe ficava perto. Os atenienses também cuidavam do corpo, mas como não desprezavam o espírito, tornaram-se o povo mais culto e artista da antiguidade. Cultivavam bíceps nos ginásios, e fora deles a música, a poesia, a retórica, a pintura e a escultura. Em algumas artes ainda não foram excedidos até hoje. Licurgo não conseguiu que Esparta suplantasse Atenas.

Uma vez, numa festa esportiva, um velho que entrara à última hora pôsse a procurar assento na parte das arquibancadas que os atenienses ocupavam. Nenhum lhe cedeu lugar. Vendo isso, os espartanos, que estavam do outro lado, chamaram o velho e ofereceram-lhe o melhor lugar. Os ateniense aplaudiram com palmas o belo gesto dos espartanos. Estes comentaram laconicamente: Sabem, mas não praticam, querendo dizer que os atenienses sabiam o que era direito mas não o faziam - de ruindade.”[p.48-50]

\section{“XV - A coroa de louros"}

“- Os gregos, tanto rapazes como raparigas, continuou dona Benta, gostavam e cultivavam toda sorte de esportes ao ar livre. Naquele tempo não havia futebol, mas havia corrida, o salto, a luta que chamamos romana, o boxe e o lançamento de rodelas, ou pesados discos de ferro.

Periodicamente se realizavam disputas nas diferentes cidades da Grécia, para tirar-se a limpo quais os campeões; mas a grande prova era a que se repetia de quatro em quatro anos na cidade de Olímpia, ao sul da Grécia. Com o tempo esses Jogos Olímpicos se tornaram a coisa mais importante da vida grega, neles entrando em competição os melhores atletas de todas as cidades. 
As olimpíadas, isto é, a temporada de jogos em Olímpia, duravam cinco dias. Cinco dias de feriado nacional, porque os jogos eram oferecidos a Zeus ou Júpiter. Vinha gente de todas as cidades assistir às festas, como hoje vem gente de todos os países quando nalgum deles é inaugurada uma exposição universal. Mas só os gregos podiam tomar parte nos jogos - e só os que nunca houvessem cometido crimes, ou infringido qualquer lei.

Tinham enorme importância para os gregos esses jogos. Tanta importância, que se por acaso coincidia estarem em guerra entre si ao tempo de começar a festa, interrompia-se a luta. Só depois de findos os jogos a guerra continuava.

Que bom sistema!

- Os rapazes gregos, que pretendiam tomar parte nos jogos, treinavam durante quatro anos; e nove meses antes das provas mudavam-se para Olímpia, afim de se aperfeiçoarem nos ginásios ao ar livre, junto ao estádio.

Depois de cinco dias de provas, havia paradas e sacrifícios religiosos aos deuses, aos quais se erguiam estátuas em redor do estádio.

- Que bonito, vovó! exclamou Pedrinho. Estou me simpatizando muito com os gregos. Se tivesse de escolher um país antigo para morar, não queria outro senão a Grécia.

- E tem razão. A Grécia desse período foi um maravilhoso país. O esporte virara verdadeiro culto. Todos tinham de respeitá-lo. Quem trapaceasse numa prova, era posto de lado por toda a vida. Havia o que chamamos hoje de espírito esportivo. Quem ganhava não se vangloriava a quem perdia e não discutia.

- Ahn! exclamou Pedrinho. Agora compreendo o que quer dizer espírito esportivo!... É mão roncar quando ganha nem dar mil explicações, de que perdeu por isto ou por aquilo quando perde.

- Sim, disse Narizinho, mas não faça como os atenienses da festa que sabiam, mas não praticavam. Pratique, como os espartanos...

Aquilo era uma indireta a Pedrinho que na véspera havia dado mil explicações do porquê e como perdera uma corrida apostada no pomar.

- O resultado de tudo, continuou dona Benta, foi não existir maior glória na Grécia do que vencer nos jogos olímpicos. Os vencedores não recebiam prêmios, dinheiro ou coisa que valha, só recebiam uma coroa de louros. Os poetas compunham versos e sua honra e os escultores lhes imortalizavam os corpos em estátuas de mármore.

As competições não consistiam apenas em provas esportivas. Havia-as também de ordem artística: os concursos de música e poesia. Os vencedores desses concursos, em vez de receberem coroas de louro, eram carregados em triunfo pela multidão.

A primeira corrida em Olímpia, registrada pela História, foi 776 anos antes de Cristo - e a partir desse ano começaram os gregos a contar o tempo. De modo que o ano 776 antes de Cristo passou a ser o ano I dos gregos.

- E hoje, vovó, ainda há jogos olímpicos?

- Estes jogos estiveram interrompidos por muitos e muitos séculos, mas há poucos anos atrás, em 1896, recomeçaram, já não em Olímpia, sim em Atenas. Depois ficou assentado que seria cada vez num país diferente, podendo tomar parte neles os atletas de todas as nações do mundo.

- E antigamente quem era que vencia mais jogos, vovó?

- Ah, eram os espartanos! Nesse ponto a vitória de Licurgo fora completa. Os atletas de Esparta faziam verdadeiras coleções de coroas de louros. 
(Emília, que ainda estava proibida de falar, cochichou para o visconde: 'Imagine que regalo para tia Nastácia se morasse lá! Ela gosta tanto de pôr louro na comida...')’[p.50-53]

\section{“XXIII - Pérsia vs. Grécia”}

“Dona Benta escreveu num papel o título deste capítulo e perguntou ao menino o que significava aquele vs. entre dois nomes. Pedrinho não soube responder.

- Simples abreviação da palavra latina versus, que quer dizer 'contra'. Pérsia contra Grécia - é o que está escrito aqui. Na notícia dos jogos de futebol os jornais usam muito está palavra. 'Realiza-se amanhã a luta do Narizinho Futebol Clube versus o Emília Torneirinha Clube...’.

Pois naqueles tempos houve um verdadeiro match entre a Grécia e a Pérsia. Ciro, o rei dos persas, conquistara a Babilônia e outros países importantes, com exceção da Itália e da Grécia. O seu sucessor, o rei Dario, quis dar à Pérsia a dominação do mundo, e viu que faltava pouca coisa. Faltavam aquele pedacinho que era a Grécia e a tal bota italiana.

Ora, os gregos haviam fomentado uma rebelião na Pérsia, de modo que não faltou a Dario pretexto para a guerra. 'Quero puni-los pelo que me fizeram e depois anexarei suas terras às minhas'. E tratou disso. Construiu uma grande esquadra e preparou um exército que, sob o comando do seu próprio genro, fosse castigar os gregos. Mas uma tempestade destruiu a esquadra e o exército teve de voltar do caminho.

Furioso com o genro, com o mar e com os deuses, os maiores culpados do desastre, Dario decidiu ir ele próprio sovar os gregos, logo que nova esquadra e novo exército estivessem prontos. Enquanto isso, mandou mensageiros com intimação a todas as cidades gregas para lhe mandarem um punhado de terra e um pouco d'água como sinal de que se rendiam sem luta.

Tão forte e poderoso era por esse tempo o rei persa que muitas cidades gregas se apressaram em mandar a terra e a água exigidas. Atenas e Esparta, porém, recusaram-se, apesar de serem umas pulguinhas comparadas ao vastíssimo império de Dario. Os atenienses agarraram o mensageiro persa e o meteram num poço, dizendo: 'Aí tens terra e água’. Os espartanos fizeram o mesmo.

- Esparta com certeza limitou-se a jogar o mensageiro no poço sem dizer coisa nenhuma, observou Narizinho. Isso é que seria uma resposta bem lacônica...

- Realmente, minha filha. A uma resposta dessa poderíamos chamar o cúmulo do laconismo, porque nem uma só palavra seria necessária - bastava o ato... Mas era isso o que Dario queria - os preparativos para a guerra foram intensificados. Fez ele construir grande número de trirremes.

- Que é trirreme, vovó?

- Uma embarcação de bom tamanho, movida de cada lado por três ordens de remo.

- Não entendo bem...

- Sim, três ordens de remos de casa lado - isto é, uma fileira de remos em cima, outra um pouco abaixo e a terceira ainda um pouco mais abaixo - e dona Benta desenhou uma trirreme.

- Pois é, continuou depois; os persas construíram 600 trirremes, que levavam, cada uma, 200 soldados, além dos remadores. O exército inteiro tinha - quantos homens, Pedrinho? Depressa, de cabeça...

- Doze mil! Respondeu o menino.

- Cento e vinte mil! emendou Narizinho, que era muito boa no cálculo rápido. 
- Um milhão e duzentos milhinhos! gritou lá do fundo a boneca.

- É isso mesmo, Narizinho, disse dona Benta, fingindo não ter ouvido o cálculo da Emília. Cento e vinte mil homens foram embarcados e, como não houvesse tempestade durante a travessia, todos chegaram sem novidades às praias da Grécia.

- Em que ponto desembarcaram?

- Numa planície de nome Maratona, a dezoito quilômetros de Atenas. Assim que os atenienses souberam da chegada dos persas, trataram de avisar o povo de Esparta. Esparta ficava a 240 quilômetros de Atenas. Se fosse hoje, não seria nada essa distância. Hoje manda-se uma comunicação daqui à China em alguns segundos. Mas naquele tempo não havia telégrafo, nem telefone, nem trem, nem avião - nada rápido. $\mathrm{E}$ parece que em Atenas nem bons cavalos havia, porque num momento de tanta gravidade o meio usado para se comunicarem com Esparta foi um mensageiro a pé, de nome Feidipedes. Feidipedes correu a noite e o dia inteiros, sem parar sequer para comer - e no segundo dia chegava a Esparta.

Mas não lhe valeu correr tanto, porque os espartanos declararam que, como estavam na lua minguante, não podiam partir em socorro de Atenas; tinham de esperar pela lua cheia... Havia em Esparta essa superstição, como nós temos aqui a da sextafeira e a do pé esquerdo e mil outras.

Os espartanos podiam esperar pela lua cheia porque estavam longe dos persas, mas os atenienses não podiam esperar nem um minuto - e marcharam contra eles. $\mathrm{O}$ exército ateniense compunha-se de apenas dez mil homens, comandados por Milciades; contava ainda com mais mil homens de uma cidade vizinha, aliada a Atenas. Total: onze mil - ou menos de um para cada dez soldados persas.

- E aposto que os gregos vão vencer, disse Pedrinho. Quando os contadores de história começam com esses cálculos, é para preparar uma surpresa...

Dona Benta riu-se da finura do neto.

- Pode ser, disse ela, mas note, Pedrinho, que os gregos eram atletas admiráveis, como não havia outros no mundo, de modo que o número de persas não significava grande coisa. O resultado foi a derrota completa de Dario em Maratona. Note ainda que os gregos estavam lutando pela própria vida, e coisa nenhuma dá mais coragem aos homens do que isso. Não sabem a história do cão e da lebre?

Ninguém sabia.

- Um cão perseguiu uma lebre sem poder alcançá-la. Os outros caçoaram dele. 'Esperem lá', disse o cão. 'Eu estava correndo por esporte, mas a lebre correu para salvar a vida. Era natural que ganhasse'.

- E que aconteceu depois aos gregos, vovó?

- Aconteceu que os gregos ficaram numa grande alegria. Feidipedes, o mensageiro que levara o aviso a Esparta e também se batera em Maratona, logo depois da batalha partiu de carreira para Atenas afim de dar a grande notícia. Mas ainda não estava refeito do grande esforço da primeira corrida, de modo que ao alcançar a praça do Mercado deu a boa nova e caiu morto.

Em honra a esse herói foi instituída nos Jogos Olímpicos uma carreira com o nome de Maratona, na qual a distância a correr era exatamente a distância entre Atenas e Maratona.

- Em que ano foi isso, vovó?

- No ano de 490 a.C. A batalha de Maratona tornou-se a mais famosa da História. O rei persa teve de voltar para o seu reino, surrado e envergonhado. Mas a coisa não parou aí. O jogo ia continuar.”[p.76-80] 


\section{“XXIV - O segundo tempo"}

“- Estou imaginando a cara desse Dario! disse Pedrinho. Apanhou de dez a zero...

- Realmente, meu filho. Ele, o soberano do maior império do mundo, derrotado por um punhadinho de gregos! Mas, não! A coisa não ficaria assim! O rei persa iria formar nova esquadra e novo exército - uma esquadra como jamais existiu outra e um exército de encher de assombro a todos e levar de vencida quantas Grécias surgissem. Dario jurou e rejurou e bufou como um tigre logrado por uma raposa. E vários anos passou a preparar o grande exército. Nisto, morreu.

- Morreu com certeza de raiva recolhida, observou a menina.

- Seja do que for, morreu e foi substituído pelo seu filho Xerxes, que do pai herdara não só o trono como também o ódio aos gregos e a determinação de destruí-los. Xerxes continuou os grandes preparativos de guerra começamos por Dario.

Mas os gregos, animados pela vitória, estavam mais do que resolvidos a não se deixarem bater em hipótese nenhuma, e como tinham a certeza de que os persas voltariam, preparam-se da melhor maneira.

Por esse tempo o povo de Atenas vacilava entre dois chefes igualmente grandes. Temístocles e Aristides. O primeiro queria por prevenção se construísse uma esquadra para a próxima guerra, e Aristides era de parecer contrário. A luta pegou fogo entre os partidos dos dois candidatos, mas como o partido de Temístocles se tornasse maior, Aristides acabou no ostracismo, apesar da sua grande fama de homem perfeito. Chamavam-lhe Aristides o Justo.

No dia da votação um homem que não sabia escrever aproximou-se de Aristides com uma casca de ostra na mão e pediu-lhe que escrevesse nela um nome. 'Que nome?' perguntou Aristides. 'Aristides', respondeu o homem. Sem dar-se a conhecer, o grande ateniense perguntou-lhe: 'Por que querer condenar este homem ao ostracismo? Cometeu ele por acaso alguma falta?' 'Oh, não!' respondeu o eleitor. 'Ele não cometeu nenhuma falta, mas...' e suspirou. 'Mas, que?' insistiu Aristides. 'Mas estou cansado de ouvir o povo chamar-lhe sempre o Justo, o Justo...' concluiu o homem.

Aristides conhecia o caráter dos gregos e portanto não se admirou daquela inconsequência. Limitou-se a escrever o seu próprio nome na casca de ostra. Concluída a votação, foi verificado haver na urna o número de votos necessário para a sua condenação - e Aristides foi para ostracismo.

-- Que grande injustiça! exclamou Pedrinho indignado com os atenienses. Isso é o cúmulo dos cúmulos!

- E que o grande acero político! disse dona Benta. O afastamento de Aristides pôs toda a força do lado de Temístocles, que conseguiu, afinal, impor a sua ideia da esquadra e mais preparativos para a possível guerra. E Temístocles acertou. A guerra veio. Dez anos depois da batalha de Maratona os persas reiniciaram a sua marcha contra a Grécia. Desta vez não com cento e vinte mil homens, mas com dois milhões.

- Dois milhões, vovó? exclamou o menino, espantado.

- Parece que mesmo um pouco meio muito, como diz o compadre Teodorico. Em todo o caso, é essa a contagem dos historiadores da época. Mas semelhante exército era em excesso numeroso para vir por mar. Seriam necessárias mais trirremes do que as havia no mundo inteiro. Por isso Xerxes determinou que a marcha fosse por terra, embora mesmo por terra houvesse um bocadinho d'água a separá-lo dos gregos: o estreito que hoje se chama Dardanelos e naquele temps se chamava Helesponto.

- De que largura era esse estreito, vovó?

- Apenas um quilômetro e meio. 
- E Xerxes passou?

- Quase. Xerxes construiu uma ponte de barcos, isto é, foi colocando barcos um encostado ao outro até alcançar o lado grego; depois estendeu por cima um tabuado como de ponte. Mas assim que concluiu a obra, uma tremenda tempestade sobreveio e arrasou tudo.

A fúria de Xerxes foi tamanha que pegou de um chicote e pôs-se a surrar o mar como se o mar fosse um de seus escravos. Em seguida mandou fazer uma nova ponte. Desta vez não houve tempestade e o exército pôde avançar. Sete dias e sete noites levou passando, em massa cerrada. A esquadra, que era enorme, o seguiu. Quando as forças alcançaram a terra da Grécia...

Dona Benta teve de parar nesse ponto. O visconde, que desde o seu 'renascimento' não dissera ainda uma só palavra, tinha dado um grito. Correram todos. Que foi? Que não foi? 'Foi Emília, eu vi' disse tia Nastácia aparecendo da cozinha, com a colher de pau na mão. 'A malvada deu em cima dele com um tal ostracismo. Não sei o que é, mas deve doer muito...’.’[p.80-82]

\section{“XXV- Ainda o segundo tempo"}

“- Havia na Grécia, disse dona Benta no serão seguinte, uma passagem muito estreita, ou desfiladeiro, conhecido como as Termópilas. Dum lado era o mar; doutro, a escarpa duma montanha. Por ali os persas tinham de passar na sua marcha rumo a Atenas.

- Térmo, vovó disse Pedrinho, significa...

- Quente. Águas termais, águas quentes. Termópilas queria dizer passagem uentqe, porque de fato havia por ali umas fontes de água quente. Mas os gregos acharam que em vez de esperar o ataque dos persas muito melhor seria atacá-los na passagem das Termópilas, onde um homem era capaz de fazer frente a muitos. E Leônidas, o rei de Esparta, foi escolhido para defender o desfiladeiro. Leônidas era um espartano digno de nome que tinha, porque Leônidas quer dizer igual ao leão. Tomou o comando de sete mil soldados bem escolhidos, entre os quais trezentos espartanos daqueles tinham aprendido a não se renderem nunca. Mas era uma loucura jamais vista escorar tamanho exército com sete mil homens apenas.

Quando Xerxes percebeu que Leônidas estava ocupando as Termópilas com aquele punhadinho de homens, riu-se, e mandou-lhe intimação para entregar-se. 'Venha buscar-nos', foi a lacônica resposta de Leônidas. Logo depois travou-se a luta, e durante dois dias os gregos sustentaram as suas posições, impedindo o avanço dos persas. Mas houve traição. Alguém foi contar a Xerxes que naquela montanha havia passagem secreta dando para a retaguarda de Leônidas, de modo que se os persas entrassem por lá os gregos seriam apanhados pelas costas.

Quando Leônidas soube que os persas tinham descoberto a passagem secreta e vinham vindo, compreendeu que tudo estava perdido. Falou aos seus homens. Contou o que se passava; disse que quem quisesse retirar-se poderia fazê-lo e que quem ficasse tinha de contar com a morte.

- E retiraram-se muitos? Perguntou Pedrinho, ansioso.

- Seis mil. Ficaram apenas mil, entre os quais trezentos espartanos. 'Nós recebemos ordem de defender esta passagem', foi a lacônica resposta que deram ao general.

Leônidas e seus mil homens lutaram nas Termópilas até o fim, morrendo todos, um por um. 
Depois que os persas atravessaram o desfiladeiro, a cidade de Atenas ficou em má situação, porque nada podia impedir o ataque. Era absurdo resistir, dada a desproporção entre atacados e atacantes. Os atenienses correram a consultar o Oráculo de Delfos.

O Oráculo respondeu que a cidade de Atenas estava condenada a ser destruída, mas que os atenienses seriam salvos por muralhas de madeira.

- Que queria dizer com isso? Perguntou Pedrinho.

- Essa mesma pergunta acudiu a todos os atenienses. O Oráculo falava sempre dum modo enigmático, que exigia interpretação. Dessas vez Termístocles traduziu a seu jeito a resposta, dizendo que tais muralhas de madeira significavam navios da esquadra, e convidou o povo a abrigar-se em barcos ancorados na baía de Salamina. Os atenienses aceitaram o convite; abandonaram a cidade e meteram-se a bordo.

Quando os persas entraram em Atenas, só viram por lá casas vazias. Puseramlhes fogo e depois marcharam para Salamina, onde a esquadra persa, ajudada pelas forças de terra, iria varrer dos mares os navios gregos. Para gozar esse espetáculo, Xerxes mandou erguer um trono no alto dum morro, donde se descortinava toda a baía.

A tal baía de Salamina assemelhava-se muito ao desfiladeiro de das Termópilas; era uma faixa d'água ou como um trecho de rio - e essa semelhança deu a Temistocles uma ideia. Fingindo-se traidor, com aquele que nas Termópilas havia revelado a passagem secreta, mandou dizer a Xerxes que se a esquadra persa fosse dividida em duas partes, ficando uma num extremo e outra no outro extremo da baía, os gregos, encurralados, nada poderiam fazer.

- E Xerxes caiu na esparrela...

- Como um patinho. Acreditou na nova 'traição' e dividiu a esquadra em duas partes. Isso foi ótimo para os gregos, que com todos os seus navios puderam atacar cada metade por sua vez, e ainda, por meio de hábil manobra, conseguiram fazer que as duas metades da esquadra persa se chocassem, com perda de muitos navios.

O resultado final foi a completa derrota dos persas no mar, e a necessidade em que ficou o exército de terra de retirar-se para a Pérsia pelo caminho mais curto.

- Estou imaginando o acesso de raiva que havia de ter Xerxes no seu trono, lá no alto do morro! disse a menina.

- E eu, os pulos de alegria de Temístocles! disse Pedrinho. Esse chefe acertou em todos os pontos - até na decifração da fala misteriosa do Oráculo. Era um danado!

A consequência da admiração do menino pelo chefe grego foi bezerro da vaca mocha, nascido na véspera, passar a chamar-se Temístocles e não Gaveta, como queria a boneca. Gaveta! Aquela Emília tinha cada uma...”[83-86]

\section{“XXVI - A Idade de Ouro"}

“- Já falamos nas Idades da Pedra e do Bronze, continuou dona Benta. Vamos ver agora um pedacinho duma verdadeira Idade de Ouro, ou época em que o bem estar do povo trouxe um grande florescimento das artes e ciências.

Depois de terminada dum modo tão feliz a guerra com a Pérsia, os atenienses voltaram para Atenas e reconstruíram as casas. E como eram um povo de grandes dotes artísticos, aproveitaram a ocasião para fazer de Atenas a mais bela cidade do mundo. Tudo os ajudou - tudo concorreu para isso.

- Quem era nesse tempo o chefe de Atenas?

- Oh! Atenas tinha um grande chefe chamado Péricles. Esse homem não era rei, nem tirano, mas possuía tal inteligência, falava tão bem, mostrava-se tão hábil político, que os atenienses começaram a segui-lo em tudo - e durante muitos anos Atenas foi na 
realidade governada por ele. Péricles lembra um capitão de team de futebol altamente querido por todos os jogadores em vista de suas qualidades. Um capitão desses leva a equipe a operar prodígios - e vencer todos os jogos. Assim foi Péricles com a Grécia.

Surgiram por esse tempo grandes filósofos, grandes escritores, grandes poetas, grandes escultores, grandes arquitetos, grandes tudo.

- Pare um pouco, vovó, disse a menina. Eu vejo sempre falar em filósofo e até já tenho empregado essa palavra; mas na verdade não sei muito bem o que quer dizer. Para tia Nastácia, filósofo é um sujeito de calça furada, que anda distraído pela rua, tropeçando nos sapos. Será isso mesmo?

- Não, minha filha. A palavra 'filósofo' quer dizer 'amigo da sabedoria'. Os filósofos são o complemento dos cientistas. Estes vão até o ponto em que podem provar o que afirmaram. Desse ponto em diante acaba-se a Terra da Certeza e começa a Terra do Pode Ser. Nesta Terra é que moram os filósofos. Se um filósofo provar por A + B a sua filosofia, mas provar de verdade...

-... ali na batata... ajudou Emília.

-... provar experimentalmente, ele deixa de ser filósofo, passa a ser cientista.

-... muda-se para a Terra do é... - ajudou de novo a Emília, e Narizinho advertiu-a de que dona Benta não precisava de ajutórios.

- Pois é isso. Por causa da grande liberdade de pensamento floresceu em Atenas um grupo de filósofos dos mais notáveis. Até hoje o que os filósofos gregos ensinaram tem grande valor, porque é difícil haver inteligência mais penetrante e clara do que a deles. Ao lado dos filósofos apareceram grandes escritores, que compuseram notáveis peças de teatro.

- O Teatro grego era como o de hoje?

- Não. Era coisa muito mais importante e muito diferente do de agora. Os espetáculos realizavam-se ao ar livre e só de dia, à beira de encostas de morro, cuja inclinação servia de arquibancada. Quase nenhum cenário, e em vez de orquestra havia um coro de cantores ou recitadores. Os artistas usavam máscaras, cômicas ou trágicas. Ainda hoje, na ornamentação dos nossos teatros, vemos esculpidas essas máscaras ou caretas gregas.

Atenas tirara o seu nome do apelido grego da deusa Atena. Por esse motivo os atenienses resolveram erigir um monumento digno dela, no alto duma colina, o qual recebeu o nome de Partenon, ou templo da virgem. Guardem esta palavra, porque o Partenon é considerado como a mais perfeita obra prima da arquitetura antiga.

- Ainda está de pé, vovó?

- Infelizmente, não. Subsistem ruínas. Dentro do Partenon havia uma estátua de ouro e marfim feita por um escultor chamado Fídias, o qual tem fama de ser o maior escultor da antiguidade. Essa estátua desapareceu. Foi uma perda de que o mundo artístico jamais se consolou.

Fídias ainda fez outras estátuas para ornamento exterior do Partenon; algumas ainda hoje são vistas nos museus da Europa, embora bastante mutiladas, esta sem cabeça, aquela sem braços. Tão célebre ficou Fídias com os seus trabalhos no Partenon, que foi convidado para esculpir a estátua de Júpiter erigida em Olímpia. Dizem os seus contemporâneos que essa estátua era um prodígio de beleza. E devia ser, pois foi incluída entre as Sete Maravilhas do Mundo.

Apesar de ser o maior escultor da época, Fídias morreu na prisão por um crime que hoje nos faz rir. Imaginem vocês que no escudo da estátua de Minerva ele reproduziu, numa das figuras de certa cena, a sua própria cara e noutra, a cara do seu amigo Péricles. Pois foi o bastante para ser denunciado como sacrílego, julgado e condenado à prisão - e na prisão morreu. 
- Por falar em escultura, vovó, li ontem uma história de colunas jônicas e coríntias que não entendi. Explique-me isso.

- Nos monumentos gregos havia três espécies de colunas, a coluna dórica, a coluna jônica e a coluna coríntia. A coluna dórica era a mais simples; tinha no alto o que chamam capitel, formado como que de um ladrilho tampando um prato fundo; e em baixo, ou na base, nada tinha - enfiava-se diretamente na terra. A beleza deste tipo de coluna residia na simplicidade e na ideia de força que dava. Por isso foi considerada como estilo masculino.

- Desaforo! Protestou Narizinho.

- A segunda coluna, a jônica, possuía uma base sobre a qual se assentava; e tinha no capitel, em vez do prato fundo tampado com o ladrilho, uns ornatos como voltas de caramujo. Era considerada como de estilo feminino.

- Toma! Gritou Pedrinho piscando para a menina. Quer dizer que vocês mulheres são caramujas.

- O terceiro estilo de coluna, continuou dona Benta, era o coríntio, o mais luxuoso, o mais enfeitado. A coluna coríntia tinha o capitel cheio de coisas, tais como folhas de acanto e outras.

- Acanto? Que é isso?

- Uma planta da Grécia que ficou célebre nas artes - uma espécie de serralha. Dizem que o capitel coríntio foi criado do seguinte modo. Um arquiteto, que andava desenhando colunas, passou um dia pelo cemitério e viu sobre o túmulo de uma criança qualquer coisa que o impressionou. Os gregos tinham o costume de depositar no túmulo das crianças cestas de brinquedos, em vez de coroas ou flores. Naquele havia sido depositada, meses atrás, uma cesta de brinquedos coberta por um ladrilho. Com o tempo, um pé de acanto nasceu por ali e envolveu a cesta em suas folhas, formando uma coisa tão linda. Tão linda que o arquiteto parou e copiou o jeitinho, para depois o aplicar no capitel duma coluna - que ficou sendo a coríntia.

- Que interessante, vovó! exclamou Narizinho. Veja como uma coisa puxa outra...

- Infelizmente, aquele glorioso período da vida grega não durou muito. Veio uma peste horrível, que dizimou os atenienses, não perdoando nem ao próprio Péricles. O grande homem dedicara-se demais ao socorro da cidade - e tantos pestosos recolheu em sua casa, que também apanhou a peste e foi-se...” [p.86-90]

\section{“XXVII- Os gregos brigam entre si”}

“- Que pena, vovó, exclamou Narizinho, que essa desgraça viesse estragar um tempo tão bonito.

- A peste não foi nada, minha filha, apesar da grande perda que causou com a morte de Péricles. Muito pior do que a peste foi o que veio depois...

- Será possível que haja alguma coisa pior que a peste? admirou-se Pedrinho.

- Há, sim, meu filho. A Guerra é cem vezes pior, sobretudo a guerra civil, isto é, guerra dentro de casa, entre filhos do mesmo país. Pois logo que o horror da peste passou, os horrores da guerra vieram estragar a linda Grécia daquele tempo.

- Conte! conte! pediram os meninos - e dona Benta contou.

- A causa da desgraça foi o ciúme que depois da vitória sobre os persas, Atenas começou a inspirar. Os espartanos tinham um grande orgulho da superioridade dos seus soldados, que realmente eram os primeiros do mundo. Atenas, que também tinha excelentes soldados, depois da grande vitória da sua esquadra em Salamina ficou, sem querer, mais do que Esparta, pois possuía uma esquadra poderosa. A bela reconstrução 
de Atenas feita por Péricles e o florescimento de todas as artes não incomodavam Esparta, porque os espartanos não ligavam grande importância à cultura. Mas a esquadra ateniense incomodava. Esparta ficava no interior e por isso não podia ter esquadra, e como não podia ter esquadra não queria que Atenas a tivesse. Considerava desaforo. Daí nasceu a guerra.

- Mas não eram um mesmo país, Esparta e Atenas?

- Eram e não eram. Ambas faziam parte da Grécia, mas cada qual se governava como queria. Esparta estava situada num pedaço da Grécia chamado Pe-lo-po-ne-so, e por isso essa terrível luta entrou para a História com o nome de Guerra do Peloponeso. E sabem quanto tempo durou? Vinte e sete anos!

- Que horror, vovó! fez Narizinho. Vinte e sete anos! Imaginem...

- Foi uma luta horrorosa, com vantagem ora para este lado, ora para aquele, mas Esparta, que quase sempre ficava de cima, acabou tomando a cidade de Atenas. Depois disto entrou na briga outra cidade grega.

- Tebas, a qual conseguiu o milagre de vencer a invencível Esparta. Os espartanos ficaram muito admirados de ver forças inimigas em seu território, coisa que durante cinco séculos jamais acontecera.

Mais tarde, quando for tempo de ler uma história do mundo das grandes, vocês verão tudo quando sucedeu nesses vinte e sete anos de luta. Por agora basta que saibam que a Guerra do Peloponeso enfraqueceu e arruinou quase todas as cidades gregas, pondo fim da importância da Grécia no mundo.

Durante esse tempo viveu em Atenas um grande filósofo de nome Sócrates, que é considerado o melhor e mais sábio homem que a humanidade produziu. Sócrates andava pela cidade ensinando os moços a pensar; mas em vez de ensinar como outros filósofos, dizendo isto é assim ou assado, empregava outro sistema - fazia perguntas e ia indo até que por si mesmo o discípulo achasse a resposta exata. A esse sistema ficou ligado o seu nome. Chama-se método socrático.

Sócrates era muito feio; careca e de nariz arrebitado. Mas apesar de serem os atenienses grandes amigos da beleza, todos gostavam dele, porque se não possuía a beleza física tinha em compensação todas as belezas morais - e não há belezas que valham estas.

Sócrates era casado com Xantipa, uma verdadeira jararaca. Xantipa jamais compreendeu o marido, ao qual vivia xingando de vadio, e indolente, de traste inútil. 'Este diabo leva a falar, a falar o tempo todo e nada de aparecer aqui com dinheiro' devia ser a xingação diária dessa senhora. Certa vez ela o descompôs com tamanha fúria que Sócrates achou prudente fazer uma retirada estratégica. Assim que ia saindo, Xantipa jogou sobre ele um balde d'água. O grande sábio apenas murmurou: 'depois da trovoada vem a chuva' - e nada mais.

- Ah, se fosse comigo! exclamou Pedrinho, arregaçando as mangas.

- Batia-lhe com um pau, não é verdade? disse dona Benta. Pois seria um ato mui vulgar e réles. Não há brutamonte na roça que não faça o mesmo. Justamente porque em vez de bater em Xantipa, Sócrates respondeu de maneira tão fi-lo-só-fi-ca, é que estamos a falar nele. Procure nunca ser vulgar, Pedrinho, que você acertará.

Sócrates não acreditava nos deuses gregos, embora nada dissesse em público, porque os gregos não admitiam que ninguém brincasse ou descresse de tais deuses. Mas um homem com a cabeça de Sócrates não podia tomar a sério o senhor Júpiter nem a senhora Vênus, e por isso, sem falar mal deles, também não falava bem. Calava-se. Era como se não existissem.

Foi o bastante para incorrer nas iras do povo, sendo denunciado como inimigo dos deuses e corruptor da mocidade. Resultado: condenação à morte. 
- Que horror, vovó! Já estou ficando com ódio nos gregos. Por uma coisinha a toa mataram Fídias, que era o maior escultor; agora vão matar Sócrates, o melhor e o mais sábio dos homens! Isso é demais. E com certeza o enforcaram...

- Felizmente não chegaram a essa monstruosa brutalidade. Intimaram-no a beber uma taça de chá de cicuta, planta venenosíssima. Sócrates obedeceu - e morreu a mais bela das mortes, rodeado de seus queridos discípulos em lágrimas. Tinha então setenta anos. A morte de Sócrates é uma das cenas mais altas do drama da humanidade.

Emília declarou que ia plantar cicuta na horta.

- Para quê? Perguntou Narizinho. morte...”[p.90-94]

- Para não ser preciso enforcar o visconde, se alguma dia ele for condenado à

\section{“XXVIII- A esperteza da Macedônia”}

“No outro dia dona Benta falou dos meninos que começam 'sapeando' um brinquedo e por fim se metem nele e acabam donos de tudo.

- Foi o que aconteceu na Grécia. Enquanto Atenas, Esparta e outras cidades se debatiam naquele terrível brinquedo de guerra, um senhor Filipe, rei de Macedônia, espiava por cima do muro, esperando a ocasião de entrar no jogo. Filipe viu que Atenas e Esparta estavam exaustas da luta, a ponto de mal poderem consigo; logo, se ele pulasse o muro e entrasse no brinquedo quem virava o chefe seria ele. Ser rei da Grécia sempre fora o seu sonho. E como os gregos odiassem os persas por causa do incêndio de Atenas, o espertíssimo Filipe resolveu entrar por esse caminho.

- 'Vossos antepassados', falou ele aos gregos, 'fizeram os persas recuar; mas os persas voltaram para suas terras, muitos frescos da vida, e nunca foram punidos pelo mal feito à Grécia. Por que não tomais vingança? Por que não organizais uma boa guerra contra eles, não só para castigá-los, como também para apanhar-lhes os grandes tesouros que possuem?”

E depois acrescentou um finalzinho que era onde estava o gato, isto é, onde estava escondida a ideia secreta de Filipe:

- 'E eu, que sou o grande guerreiro que sabeis, eu me juntarei convosco para vos ajudar'.

Ninguém pareceu perceber o que havia bem lá dentro da cabeça de Filipe, exceto um ateniense chamado Demóstenes.

- Não é o tal das pedrinhas vovó?

- Sim, é o mesmo. Quando menino, Demóstenes revelou uma fortíssima vocação para orador, embora um defeito de nascença o estivesse avisando a cada passo: 'Seja tudo quanto quiser, menos orador'. De... Demós... tenes é... era gá... gago.

- E um gago a querer ser orador, é mesmo da gente dar com um gato morto em cima até que o gato mie, disse Pedrinho.

- Pois Demóstenes não levou com gato em cima, mas deu com pedrinhas na gagueira e acabou com ela e ficou sendo o mais famoso orador da humanidade. Ainda hoje, quando a gente quer dizer que um fulano de tal é grande orador diz: 'É um Demóstenes!' Não se lembram daquela festinha do compadre Teodorico, no casamento da Miloca? Como foi que o Zezinho Xarope começou o seu brinde aos noivos, no jantar?

- Eu me lembro, vovó! gritou Pedrinho, e até decorei a frase, de tão bonita que a achei. Foi assim: 'Neste momento solene, em que ergo a minha débil voz para saudar os nubentes, eu queria ter a eloquência dum Demóstenes para etc. e tal’. Foi só palmas. Na 
volta para casa a senhora nos ensinou o que queria dizer nubentes. Recordo-me muito bem.

- Pois é. Demóstenes foi um orador tão famoso que até o Zezinho Xarope se lembra dele, neste fim de mundo onde moramos. Demóstenes entendeu de acabar com a gagueira. Diariamente ia a um ponto da praia onde as ondas se quebravam nos rochedos com grande barulho. E lá se punha a fazer discursos, com pedrinhas na boca.

- Por que pedrinhas?

- Para aumentar a dificuldade. Você compreende que assim embaraçado com as pedrinhas mais difícil ainda se tornava para aquele gago discursar no meio do barulho das ondas. Mas insistiu, insistiu até que venceu o embaraço de nascença somado com o embaraço das pedrinhas - e acabou falando com voz tão alta que dominava o barulho do oceano. As ondas furiosas eram para ele o público - um público insolente, que procurava impedir que sua voz fosse ouvida. Demóstenes venceu a gagueira à força de exercício, e foi aumentando o tom da voz até vencer também o rumor das ondas. Mais tarde, quando em vez de ondas tinha diante de si multidões de homens, também sua voz dominava o barulho das ondas humanas - e Demóstenes ficou o rei dos oradores. Quem o ouvia, era conquistado pela sua eloquência a ponto de rir ou chorar, conforme o desejo do orador.

Pois bem, este Demóstenes percebeu as intenções ocultas de Filipe naquele negócio da vingança contra os persas. 'Ele quer tomar conta da Grécia e virar nosso rei' refletiu, e desde esse momento passou a aplicar toda a força de sua eloquência contra o esperto Filipe. Fez contra ele doze discursos famosos, que se chamaram as Filípicas. Quando hoje um orador qualquer pronuncia contra alguém um discurso violento, todos dizem: 'É uma filípica'.

Sempre que os gregos ouviam uma arenga de Demóstenes ficavam com ódio de Filipe; mas depois iam esquecendo e de novo se deixavam enlear pelos projetos do paciente rei da Macedônia. Afinal, Filipe venceu. Acabou como queria - rei da Grécia; mas não pode realizar o seu plano de guerra porque morreu assassinado por um dos seus generais.

- Isso quer dizer, vovó que, embora a eloquência valha muito, a esperteza ainda vale mais, observou o menino.

- Na verdade, meu filho, a esperteza é tudo na vida. Quem lê a história dos homens, vê que a esperteza acaba sempre vencendo. Vence até a força bruta.

Filipe tinha um filho chamado Alexandre, com vinte anos de idade nessa época, o qual passou a ser rei da Macedônia e da Grécia juntas e realizou grandiosos planos do pai. Era uma criatura extraordinária esse Alexandre, com todos os dons de inteligência e da beleza. Quando ainda meninote, aconteceu-lhe um caso famoso, certa vez em que assistia a uns exercícios de equitação. Sabem o que é equitação?

- Sei! Gritou Emília, que tinha estado quieta uma porção de tempo. Equitação é coisa de cavalo. Andar a cavalo, montar a cavalo, cair do cavalo, puxar o rabo do cabalo, dar milho para o cavalo, pentear a crina do cavalo...

- Pare, que já errou! disse dona Benta. Equitação é o nome da arte de montar nos cavalos - só isso. Puxar rabo de cavalo não é equitação - é reinação perigosa. Mas ao assistir àquelas provas, Alexandre viu que nenhum dos presentes conseguia montar certo ginete muito fogoso. Parecia assustadíssimo o animal, dando tais pinotes e corcovos que ninguém podia firmar-se na cela. Percebendo que o cavalo estava assustado com a sua própria sobra, Alexandre disse ao pai: 'Papai, dá licença que eu monte esse animal?' O rei Filipe achou graça e riu-se gostosamente. 'Que absurdo, meu filho! Pois não vê que cavaleiros velhos, peões de primeira ordem não conseguem fazêlo sossegar?' 'Pois eu conseguirei', afirmou o menino. O pai, sempre a rir-se, deu a 
licença pedida, e Alexandre, dirigindo-se até o cavalo, virou-o de modo que ficasse de frente para sol e, portanto, sem poder ver a própria sombra. Imediatamente o cavalo sossegou e deixou-se montar. Tão alegre ficou Felipe com a habilidade do filho, que lhe deu o cavalo como prêmio. Chamava-se Bucéfalo. Esse famoso corcel foi por muito tempo a montaria predileta de Alexandre; quando morreu teve estátua, e ainda várias cidades batizadas com o seu nome.

- Que danadinho, o tal de Alexandre!

- Habilíssimo. Alexandre teve uma grande coisa consigo, que talvez explique tudo quanto fez de importante na vida; foi discípulo de Aristóteles, o maior professor que a humanidade possuiu até hoje.

- A humanidade, vovó? Não está achando isso meio muito? observou Pedrinho com cara de dúvida.

- Não é muito, não. Este Aristóteles escreveu uma porção de livros importantíssimos sobre todas as coisas - sobre os astros...

- Astronomia! gritou Pedrinho.

- ...sobre os animais...

- Zoologia!

- ... sobre as plantas...

- Botânica!

- ... sobre a política e sobre o modo da cabeça da gente funcionar, isto é, sobre o espírito, as ideias, a inteligência, etc. Como se chama esta ciência, senhor sabidão?

Pedrinho engasgou.

- Cabeçologia! gritou lá de longe a boneca.

- Psicologia, corrigiu dona Benta, estudo da alma ou do espírito. Sobre todos esses assuntos escreveu Aristóteles, e tão bem que durante muitos séculos...

- Séculos, vovó?

- Séculos, sim. Desde o ano de 384 a.C., data do seu nascimento, até hoje, temos 2.327 anos, ou mais de vinte e três séculos. Por todo esse tempo as obras desse famoso professor vieram ensinando a ciência aos homens. Antigamente, há um século atrás, os únicos livros de ensino existentes nas universidades eram os de Aristóteles. Únicos, hein? Hoje a coisa está mudada. Temos outros livros; mas tais livros não passam dos mesmos livros de Aristóteles, apenas melhorados com o que a experiência dos homens nos foi ensinando até aqui.

Este famosíssimo professor foi aluno de outro mestre de igual fama, chamado Platão, e este Platão foi disciplinado daquele Sócrates que teve que beber cicuta. De modo que os três homens que maiores serviços prestaram à humanidade como mestres da ciência, foram... Vamos lá, Narizinho...

- Sócrates, Platão e Aristóteles.

- Muito bem. Quando vocês crescerem, não deixem de ler algumas das suas obras. Vão ficar admirados do vigor da inteligência dos três filósofos gregos. Sócrates não deixou obra escrita, mas o seus discípulo Platão nos dá todas as suas ideias.” [p.9499]

\section{“XXIX- Alexandre o Grande”}

"Depois de tomar fôlego, dona Benta perguntou:

- Que é que você pretende ser quando tiver vinte anos, Pedrinho?

O menino ficou atrapalhado. Ele pretendia ser tanta coisa...

- Pois aos vinte anos o nosso Alexandre já era rei. 
- Grande milagre, vovó! Eu também seria rei aos vinte anos, se tivesse nascido filho de rei.

- Sim, não há nada demais em ser rei aos vinte anos quando um homem nasce num trono. Mas o que esse reizinho de vinte anos fez é um assombro. Apesar de rei de dois países, a Macedônia e a Grécia, não se contentou. Alexandre queria ser rei do mundo.

Para isso deu andamento àqueles planos de conquistas a Pérsia, fazendo-a pagar a guerra que cento e cinquenta anos antes Dário havia feito aos gregos. E conquistou-a. Alexandre reuniu um excelente exército, atravessou o Helesponto e penetrou na Ásia, onde os persas não conseguiram embraçar-lhe o caminho. Alexandre não saía vencedor de todas as batalhas.

Na sua contínua marcha para a frente, passou por uma cidade onde havia um templo célebre. Sabem por quê? Por causa dum nó.

- Dum nó? Que graça! Exclamou Narizinho. Um nó cego, aposto.

- Um nó cego na verdade, minha filha, impossível de ser desatado. Era o celebre Nó Górdio, do qual um oráculo havia dito que quem o desatasse conquistaria a Pérsia. Quando Alexandre soube do caso, foi examinar o nó e imediatamente viu que era mesmo um nó cego. Puxou, então, da espada e cortou-o pelo meio, de um golpe...

- Ahn! Exclamou Pedrinho. Só agora compreendo porque as pessoas que resolvem uma situação encrencada dizem: 'cortei o nó górdio!'

- Pois é isso mesmo. Usamos tal expressão por causa do que Alexandre fez há vinte e três séculos. Mas o nosso Alexandre que não era de brincadeiras, realizou a predição do oráculo: conquistou a Pérsia. De lá marchou para o Egito, quem pertencia à Pérsia, e também o conquistou. Para comemorar a vitória ergueu uma cidade perto da boca do Nilo e deu-lhe um nome derivado do seu - Alexandria. Nessa cidade que iria torna-se uma das mais importantes do mundo, fundou a mais célebre biblioteca dos tempos antigos.

- Como eram os livros?

- Escritos a mão, em tiras de papiro emendadinhas, formando rolos. Essa biblioteca foi acumulando tudo o que a humanidade havia escrito até aquela data e chegou a ter meio milhão de obras. Se séculos mais tarde não fosse queimada pelo sultão Omar, seria hoje a mais preciosa e importante biblioteca do mundo.

- Por que esse indecentíssimo Omar destruiu uma coisa tão preciosa, vovó? perguntou o menino, revoltado.

- Por puro espírito de fanatismo, meu filho. Omar que era um fanático da religião Maomé, mandou incendiar a preciosa biblioteca porque: 'Ou os seus livros dizem o mesmo que o Corão, e nesse caso são inúteis, ou dizem o contrário, e nesse caso devem ser destruídos.' O Corão é o livro sagrados dos maometanos, como para os cristãos é a Bíblia.

- Imbecil! Não era lá que havia o tal farol?

- Sim. Nessa mesma cidade de Alexandre foi erguido esse monumento notabilíssimo. O farol, o gigantesco farol cuja luz alcançava muitos quilômetros longe. Foi levantado na ilha de Faros - de cujo nome veio a palavra farol. Era uma torre de mais de trinta andares, coisa colossal numa época de construções de um e dois andares apenas.

Mas Alexandre não ficou á espera de que a biblioteca se enchesse de livros e a torre de Faros se erguesse ao trigésimo andar. Deu ordens para que tudo se fizesse e tocou para a frente. Alexandre não podia parar. Ardia por conquistar novas terras, ver novas caras, novas coisas - e esqueceu-se completamente de sua Macedônia. Em vez de 
voltar para lá, ao menos a fim de matar as saudades, marchou para diante e foi conquistando todos os países que encontrou, até a Índia.

- Que homem 'mais que os outros' era Alexandre, vovó! observou a menina. Desde meninote...

- Realmente. Alexandre era único e tinha o bicho carpinteiro no corpo. Não podia parar. Começou a ser rei aos vinte anos e desde aí até a morte jamais esquentou lugar. Morreu com trinta e três anos apenas - a idade de Cristo - e já era chamado de Alexandre o Grande. Havia se tornado senhor de todo o mundo - pelo menos de todo o mundo então conhecido e habitado por povos civilizados. Só não se lembrou da Itália ou não teve tempo de conquistá-la. Mas naquele tempo a Itália não passava de uma porção de cidades pouco povoadas e sem nenhuma importância.

Quando Alexandre viu que nada mais restava que valesse a pena vencer, dizem que chorou...

- E como não tinha mais mundo para conquistar resolveu morrer, não é?

- Mais ou menos. Não vendo inimigos pela frente contra os quais lançasse o seu exército, Alexandre resolveu voltar para a Grécia; mas com muita preguiça, lentamente, parando pelo caminho para gozar a vida em festas. E assim alcançou a cidade de Babilônia, que já não era nem sombra do que havia sido nos tempos da grandeza. Lá morreu repentinamente durante um banquete, no ano 323 a.C.

Este Alexandre deveu muito e muito a Aristóteles. Foi Aristóteles quem lhe ensinou a ser um grande homem. Nas suas conquistas prestava grandes benefícios aos povos dominados. Ensinava-lhes a língua grega, de modo que pudessem cultivar o espírito lendo os únicos livros de valor existentes na época, os livros gregos; ensinavalhes os esportes atléticos praticados em Olímpia; ensinava-lhes as artes - a pintura, a escultura, a música. Sua preocupação era melhorar a cultura dos vencidos. Podemos até dizer que com seus livros ninguém ensinou mais aos homens do que Aristóteles e com sua espada ninguém ensinou mais aos povos que seu discípulo Alexandre.

Alexandre casou-se com uma rapariga persa de grande beleza, chamada Roxana, e morreu antes de lhe nascer o único filho, de modo que a chefia do império coube aos seus generais.

- Aos quais?

- 'O mais capaz que governe', tinha sido a recomendação de Alexandre. 'Lutem entre si e vejam qual o mais forte. Esse deverá ser meu sucessor’. Os generais lutaram entre si, mas a vitória empatou entre quatro. Em vista disso o império de Alexandre foi dividido em quatro, cabendo cada parte a um deles.

Destes generais só um realmente tinha qualidades de chefe, ou rei - um chamado Ptolomeu. Governou o Egito sob nome de Ptolomeu I e governou bem, formando uma dinastia, isto é, fazendo que seus filhos governassem depois dele. Os outros generais não souberam conservar os reinos recebidos, de modo que depois de alguns anos nada mais restava do grande império de Alexandre.

- Tal qual um balãozinho de elástico que a gente assopra, e ele enche e enche até que - paf! estoura e não fica coisa nenhuma, observou Pedrinho filosoficamente.” [p.100-103]

\section{“XXXIV- O imperador divinizado"}

“A cidade de Roma, como capital do mundo, havia desbancado em população e grandeza todas as cidades antigas. Mas faltava-lhe beleza. Augusto resolveu enchê-la de monumentos, e substituir as casas de tijolo por outras de mármore. Um dos notáveis monumentos construídos nessa época foi o Panteon. 
- Não quer dizer o mesmo que Partenon?

- Partenon vem do nome da deusa Minerva - Athene Pharthenos; e Panteon é a palavra formada de duas outras - Pan, quer dizer 'todos' e teon, que quer dizer 'deuses'. Era um templo erigido a todos os deuses.’[p.120]

\section{"LVI- A guerra dos cem anos"}

“A batalha de Crécy marcou o princípio da guerra dos cem anos, que tanto atraso trouxe para a Inglaterra e para a França. No ano seguinte rompia na Europa uma célebre peste, conhecida como Peste Negra.

- Como aquela que arrasou Atenas no tempo de Péricles?

- Pior. A peste de Atenas ficou só em Atenas, mas a Peste Negra de ano 1339 espalhou-se por toda parte, Tinha vindo das bandas de Catai e ninguém pode fugir dela. Matou quanto quis. Matou mais, talvez, do que todas as guerras juntas. Tinha o nome de Peste Negra porque começava com umas manchas negras pelo corpo dos doentes; a morte vinha às vezes em horas, outras vezes em dois, três dias. Como não houvesse remédio, muitos se suicidavam logo que as manchas apareciam.”[p.214]

\section{“LXI - Nova aurora”} palavras?

“- Renascimento! Renascença! começou ela. Sabem o que significam estas

- Renascimento, disse Pedrinho, deve ser nascer de novo. Não entendo, porque o que morre, morre e não nasce mais.

- É um modo de dizer, explicou dona Benta. Na realidade, nada nasce outra vez - mas pode parecer que nasce. Foi o que se deu. Aquele período na Grécia, no tempo de Péricles, em que surgiram tantos artistas maravilhosos, renasce na Itália ali pelo século XVI. Apareceram grandes arquitetos, que construíram monumentos belos como os dos gregos. Apareceram escultores que se igualaram a Fídias. Apareceram pintores que ficaram os mais célebres do mundo.

O povo abriu os olhos. As obras dos filósofos gregos foram publicadas e voltaram a ser lidas. Tudo como se aquela Atenas de Péricles tivesse saído o túmulo para de novo iluminar a terra.’[p.240]

\section{“LXXIV- Um pouco de música”}

"No começo, lá muito longe, dizem que Apolo tomou uma caveira de boi e atou nos chifres sete cordas de tripa, bem esticadas. Assim, nasceu o primeiro instrumento musical, chamado lira. Sete cordas apenas, entre chifres de boi, não davam instrumento muito aperfeiçoado e não deviam produzir belos sons. Apesar disso a lenda conta que Orfeu, filho de Apolo, conseguiu tanger a lira com tanta perfeição que quando tocava os animais todos, e até as árvores e rochas, vinham colocar-se em redor dele para ouvir.

Depois surgiu Pã, o deus das florestas que inventou a chamada flauta de Pã. Consistia em canudos de vários tamanhos unidos entre si como dedos, que ele tocava soprando. A lira de Apolo e a flauta de Pã foram os primeiros instrumentos de música que o mundo conheceu. A lira tornou-se a mãe de todos os instrumentos de corda, e a flauta de Pã originou todos os instrumentos de sopro. As cordas mais grossas e os canudos mais largos davam as notas chamadas graves; as mais finas e os mais estreitos davam as notas agudas. 
Esses instrumentos primitivos foram se aperfeiçoando e tomando formas novas até chegarem ao piano, que tem dezenas de cordas, e ao órgão, que é uma máquina de produzir os mais belos sons de sopro.

Sabemos hoje como eram os instrumentos de música dos antigos, mas ignoramos como era a sua música. Infelizmente não existia o fonógrafo para trazer até nós esses sons. Já os nossos netos daqui a mil anos serão mais felizes. Doravante os discos de fonógrafo vão conservar por séculos as músicas tocadas hoje.”[p.291-292]

LOBATO, Monteiro. Caçadas de Pedrinho. 1ed. São Paulo: Globo, 2008 (1933). Não encontramos referências à Grécia.

\section{LOBATO, Monteiro. Emília no País da Gramática. 1 ed. São Paulo: Globo, 2008} (1934).

“- Quem é aquele figurão? - perguntou SER franzindo as sobrancelhas.

- Pois é o nosso grande Visconde de Sabugosa, um verdadeiro sábio da Grécia. Gosta muito de arcaísmo e outras velharias.” [p.62]

“- Estou pensando em coisas passadas - respondeu o excelente paquiderme. Estou pensando na velhice destas palavras. Vieram de muito longe, sofreram grandes mudanças e continuaram a transformar-se, como essa PENA de escrever que acaba de perder um N. A maioria delas já morou na antiga Roma, há dois mil anos. Depois espalharam-se pelas terras conquistadas pelos romanos e misturaram-se às palavras que existiam nessas terras. E vieram vindo, e vieram até chegarem ao que hoje são. Enquanto vocês estavam de prosa com PENA (dó), eu pus-me a recordar a forma dessa palavra no tempo dos romanos. Escrevia-se POENE. E antes, ainda de escrever-se assim, escrevia-se POINE, no tempo ainda mais antigo em que ela morava na Grécia.” [p.75]

“- Mas, por que chamam híbridas a estas palavras feitas só de grego? - indagou o menino. - Híbrido, que eu sei, é o burro e a mula, filhos de jumento e égua. Será que estas palavras são as mulas da língua? Vou perguntar à velha. [...]

Emília juntou uma porção de palavras gregas e latinas para fazer, lá no sítio, uma criação de palavras Híbridas.” [p.92-93]

“- Meu nome é grego e formado por duas palavras gregas - ORTHOS e GRAPHIA. ORTHOS quer dizer 'correta' e GRAPHIA quer dizer 'escrita'. Sou, portanto, a Escrita Correta, ou a que ensina a escrever corretamente.” [p.129-130]

\section{LOBATO, Monteiro. História das Invenções. s/ ed. São Paulo: Círculo do Livro, s/d} (1935).

“- Onde surgiu o algodão?

- Um antiquíssimo historiador grego, Heródoto, fala que veio da Índia, mas não temos meios de saber com certeza. É antiquíssimo, embora só modernamente sua cultura tomasse a grande extensão que tomou. Hoje a base do vestuário humano é o algodão. Mais que a lã, mais que a seda, que o linho, que tudo.

Os povos naqueles tempos eram vitimados por calamidades constantes. Cada inverno rigoroso dava lugar a hecatombes, sobretudo de crianças. O problema do 
vestuário ainda não estava bem resolvido. Só seria bem resolvido com a lã - a lã apareceu. Os homens tiveram a esperteza de domesticar o animalzinho que os romanos chamavam de ovis e nós chamamos ovelha ou carneiro - um animal muito tímido, de muito bom gênio, que só sabe fazer três coisas: obedecer ao pastor, pastar capim e produzir lã. Todos os anos tosavam-lhe a lã e com ela teciam um vestuário quentinho, o melhor de todos para regiões frias.

- E onde começou isso?” [p.27]

“- Se eu fosse arranjar todas as maluquices que vocês imaginam, acabaria no hospício... Mas o fato de os moradores da casa lacustre terem o banho à mão é muito importante; porque uma das características do homem é lavar-se e lavar coisas. Hoje temos pias e banheiros comodíssimos, com água corrente, quente ou fria à vontade. Isso, entretanto, é coisa moderna. Grandes metrópoles antigas, que hoje veneramos em suas ruínas, eram porquíssimas. Em Atenas os suínos andavam pelas ruas, encarregados da limpeza pública. Em Marselha, ainda em nossos tempos, certos hotéis anunciam eau courante - água corrente, dando ideia de que água corrente seja novidade digna de anúncio.” [p.34]

"Mas a invenção da casa não resolvia todos os problemas. Nos países em que no inverno na neve cobre tudo com o seu manto de gelo, mesmo dentro de casa o homem arcava com os horrores do frio. O remédio era acender fogo. $\mathrm{O}$ fogo aquece o ar, o que é agradável; esse prazer fez que se fossem aperfeiçoando os meios de aquecer o ar dentro das casas. Inventou-se o fogão para substituir as fogueiras primitivas que enfumaçavam tudo. No fogão a fumaça é levada para fora por meio dum tubo vertical que chamamos chaminé. Foi um passo gigantesco, e até hoje tal sistema é usadíssimo. Depois vieram os aperfeiçoamentos do fogão - vieram os radiadores.

- Que é isso?

- Um meio de fazer o calor penetrar nas casas sem nenhum fogão visível. Constroem-se nos porões umas fornalhas que evaporam a água, e o vapor vai por encanamentos escondidos dentro das paredes até uma serpentina de ferro. Essas serpentinas são os radiadores. $\mathrm{O}$ calor aquece o ferro da serpentina e irradia-se pelas salas e quartos.

- Mas isso é muito moderno, não, vovó?

- Menos do que parece, meu filho. No Palácio de Cnossos, na ilha de Creta, já havia radiadores mil anos antes de Cristo. E as casas construídas pelos romanos (as casas dos ricos, está claro) já usavam um sistema de aquecimento por meio de ar quente. Mas veio aquela invasão dos bárbaros que destruiu a civilização dos gregos e romanos, dando começo à triste e fria Idade Média, em que era moda desprezar o corpo, como se não fôssemos corpo. A arte do aquecimento desapareceu, isto é, voltou para trás. Resumiu-se à fogueira dentro de casa. Os pobres medievais, coitados, viviam entanguidos. E mesmo depois, já quase nos tempos modernos, o frio muito martirizou a humanidade.”[p.37]

“- Não. Apenas madeira fóssil, isto é, que ficou soterrada por muitos milhões de anos. Dizemos de pedra porque tem a aparência de pedra, e também para distingui-lo do carvão de madeira. Em muitos pontos do globo esse carvão mostrava-se em veios à flor da terra. Os romanos deram-lhe o nome de carbo, donde vieram as palavras carbono e carvão. Os gregos chamavam-lhe anthrax, donde veio a palavra antracite, que designa uma qualidade do carvão. Os antigos povos do centro da Europa chamavam-lhe kol, donde surgiu a palavra inglesa coal, que é como lá chamam ao carvão. 
- Mas por que o carvão produz energia?” [p.68]

"Hoje tudo mudou com o rádio. Os navios podem ser avisados do perigo sem grito, nem luz nenhuma. Basta uma comunicação lançada ao ar. Os navios a apanham onde quer que estejam e ficam sabendo o que há. Por meio dele os homens em terra podem comunicar-se constantemente com os que estão no mar.

Mas quanto tempo e quantos passos até chegarmos a esse ponto! Para dar sinais ou pôr-se em comunicação, o homem lançou mão dos meios que já vimos e ainda de outros. O pombo-correio, por exemplo. Essas aves possuem um extraordinário senso de orientação que lhes permite voltar para casa de onde quer que sejam soltas. O homem utilizou-se desse senso de orientação para transformar os pombos em correios, ou portadores de recados.

Aqui já é a vista auxiliando a boca. Um recado escrito corresponde a uma falação sem sons.

Foram usadíssimos os sinais que se dirigiram aos olhos, cujo alcance é muito maior que o dos ouvidos. No mar, antes do rádio, os navios comunicavam-se uns aos outros, ou com a terra, por meio de sinais semafóricos. Com várias bandeiras, erguendoas ou acenando-as de vários jeitos, ora com uma ora com outra, conseguiam dizer o que desejavam. E na Antiguidade os sinais visíveis aos olhos foram usados para transmitir com rapidez notícias ou ordens. Quando a cidade de Troia foi tomada pelos gregos, a notícia chegou a Atenas por meio de sinais de fumaça.” [p.113-114]

"Surgiu o archote. Se embebermos uma corda de fibra em óleo formaremos uma corda gordurosa, que se queima lentamente até o toquinho final. Os gregos usaram muito o archote. Nos poemas de Homero há archotes em penca.

Veio depois um progresso. Em vez de embeber a corda no óleo, colocavam nele uma cordinha - mecha ou pavio, e obtinha-se luz melhor. Esse sistema de iluminação perdura até hoje. Só tem variado o óleo. Usou-se o de baleia. Vieram depois os óleos vegetais, como o da mamona, e por fim o óleo mineral, ou petróleo, que é o mais barato.

Por milhares de anos o homem iluminou suas noites assim, apesar da incômoda fumaça desprendida por tais lâmpadas. Um progresso grande foi a vela em que o pavio se reduz ao mínimo e fica dentro dum cilindro de matéria queimante. A cera passou a ser usada, e até hoje a vemos nas igrejas - os círios. Apareceram depois as velas de espermacete, que é a massa que as baleias possuem na caixa craniana. Surgiu também a vela de sebo, e finalmente as velas modernas de estearina, em que o espermacete e o sebo são substituídos por uma mistura graxa.” [p.127]

“A grande proeza dos olhos, porém, foi em relação ao céu. A infinidade de estrelas que enchem o espaço à noite sempre impressionou vivamente a imaginação humana. Surgiram os astrônomos, isto é, os homens que se dedicam aos estudos os astros. Na Babilônia, no Egito, na Grécia, a ciência do céu alcançou grande desenvolvimento. Mas só usavam nesses estudos os olhos naturais.” [p.130]

\section{LOBATO, Monteiro. Aritmética da Emília. 1ed. São Paulo: Globo, 2009 (1935).}

“- O Visconde achou! - O Visconde achou! Corram todos! O Visconde achou!

A gritaria foi tamanha que Dona Benta, Narizinho e Pedrinho acudiram em atropelo.

- Que foi? Que aconteceu? 
- O Visconde achou! - repetia a boneca entusiasmada. - O danadinho achou!...

- Mas achou que coisa, Emília?

- Não sei. Achou, só. Quando entrei na sala, encontrei-o batendo na testa e exclamando: 'Heureca!' Ora, Heureca é uma palavra grega que quer dizer 'achei'. Logo, ele achou.” [p. 14]

“- Fazedores!

Quindim levou um susto; depois riu-se.

- Você é boba, Emília - disse ele. - Que adianta estar insistindo nisso? Uma andorinha não faz verão. Por mais que queira que seja fazedores, o mundo inteiro continuará dizendo fatores. Perca essa bobagem.

- E por que você não perde esse chifre no nariz? Onde já se viu um sábio da Grécia com um chifre no nariz?

- Sou assim porque a natureza me fez assim - respondeu resignadamente o rinoceronte.” [p. 62]

LOBATO, Monteiro. Geografia da Dona Benta. 8 ed. São Paulo: Brasiliense, 1957 (1935).

\section{“O universo. Bailado das estrelas no espaço.”}

“Geo em grego quer dizer terra, e grafia quer dizer escrever ou descrever. A geografia só descreve o que está em cima.

- E a geometria? Também tem Geo no nome...

- Essa mede as coisas da terra. Mas na 'História do Mundo' eu já contei como se formaram os mundos. Agora iremos dar um passeio pelo nosso mundinho, para ver o que a natureza pôs em cima dele, e também as mudanças que os homens, com as suas reinações, fizeram na superfície da casquinha.” [p.08]

\section{“A Terra é redondinha”}

“- Depois que acaba o ar vem o éter.

- Aquele de cheirar? - perguntou Emília, que certa vez ficara tontinha ao cheirar um vidrinho de éter.

- Não. Esse líquido que você conhece é uma droga de farmácia, chamada Éter Sulfúrico. O Éter de que eu falo é uma invenção dos filósofos gregos, que os sábios ainda hoje usam. É... é...

Dona Benta engasgou. Não sabia como definir o Éter de maneira que os meninos entendessem. Por fim disse:

- É uma espécie de ar que não é ar, nem coisa nenhuma conhecida. Sua função consiste em encher o espaço entre os planetas. O éter é uma coisa hipotética. Sabem o que quer dizer hipotética?

- Sei! - gritou Pedrinho, que sabia mesmo. Hipotético é o faz de conta dos sábios. Quando eles não podem dar explicação exata de certa coisa, arranjam uma explicação jeitosa, com o nome de hipótese, e essa hipótese fica no lugar da explicação verdadeira, guardando a cadeira, como um chapéu.” [p.17-18] 


\section{“A velha China”}

“Ora, povos que ainda admiram mais a Napoleão do que a Sócrates será que merecem o nome de civilizados?” [p.168]

\section{“No Mediterrâneo”}

“- Estamos finalmente no Mediterrâneo, o mar 'mais histórico' que existe, pelo menos para nós ocidentais. Se estas águas falassem... aqui se desenvolveram os grandes povos da nossa civilização, os gregos, os romanos, e hoje se desenvolvem os seus continuadores, os franceses, os italianos, os espanhóis e outros. Olhemos pela luneta. Lá está a Grécia! Uma ponta de terra picadinha de ilhas e golfos.

-Só aquilo, vovó? - exclamou a menina admirada.

- Sim, minha filha. Essa Grécia imensa que encheu o mundo, a terra de Sócrates, de Platão, de Apeles, de Fídias, de Aristóteles, de Praxíteles, de Péricles, a grande Grécia de que vivemos a falar, desenvolveu-se ali naquela terrinha insignificante. Não é à toa que os sábios a consideram como um milagre - como alguma coisa fora do natural, do normal.

A Grécia foi um clarão cuja luz até hoje ilumina o mundo. Quando digo 'mundo’ refiro-me ao Ocidente, porque para o orgulho do Ocidente o resto do mundo não é mundo.

- Até hoje ilumina, vovó? Por quê?

- Porque até nós que somos lá dum confinzinho do Brasil, não exprimimos um pensamento sem recorrer a ideias, expressões ou palavras que tiveram origem nesse clarão da Grécia. Que estamos fazendo? Estudando Geografia. Nesta palavra (Geografia já transparece a Grécia, porque é formada de duas noções gregas - geo, terra e grafos, escrever). Tales de Mileto (e Dona Benta apontou a luneta para a cidadezinha de Mileto, na Ásia Menor, hoje com o nome mudado para Palatia), foi o primeiro a escrever que a terra é uma bola. Depois outro sábio grego de nome Hecateus, apresentou a teoria dos continentes, sendo por este motivo considerado o pai da Geografia. Em seguida vieram Heródoto, Aristóteles, Ptolomeu, que amamentaram e criaram a ciência recém nascida. Como vocês estão vendo, a Grande Grécia vive dentro de nós, nas nossas palavras e nas nossas ideias.

E no entanto essa Grécia imensa morreu. O país que hoje tem seu nome e lhe ocupa as terras já não influi em nada no mundo. É um paizinho aí no tamanho do Ceará, com uma população de 14 milhões de habitantes.

- São os mesmos gregos daquele tempo?

- Não. Misturaram-se demais. Os gregos de hoje foram uma colcha de retalhos de raças. A capital ainda é a mesma - Atenas, cidade de menos de 200 mil habitantes. Visitadíssima por turistas e sábios e poetas - não pelo que é, mas pelo que foi. O que há de notável em Atenas são as ruínas históricas, entre elas as do imortal Partenão, construído no tempo de Péricles, no alto da Acrópole, por uma trindade de artistas de gênio - Fídias, Ictino e Calícrates. Acrópole era o nome dum morrinho que havia lá.

Os meninos, de luneta enfocada sobre a Acrópole, contemplaram por longo tempo as ruínas do Partenão.

- Sou muito crila, vovó, para entender a beleza daquilo - disse Pedrinho, meus olhos sentem prazer em olhar...

- A beleza desse monumento vem de que suas ruínas ainda deixam entrever a perfeita harmonia das proporções. Beleza é isso: harmonia de proporções. Por que motivo achamos feio um homem de pernas muito compridas ou muito curtas, ou de 
cabeça grande demais, ou de mãos enormes, como as do Elias Turco? Simplesmente porque esses membros não guardam proporção com o resto do corpo.

Olhem a légua e meia de Atenas fica o porto de Pireu, que era a grande porta de entrada e saída da grande Grécia. E aquelas outras cidades são, Andrinópola, ou cidade de Adriano, e Galípoli. Aquela adiante é Patres, a cidade das frutas. Aquela mais a Oeste, para onde vamos caminhando, é Corfu, na ilha do mesmo nome. Por todas essas terras fragmentadas as ruínas são inúmeras, constituindo a maior riqueza da Grécia de hoje.

- E de que vive a Grécia de hoje?

- Do mesmo que vive o bichinho homem em todas as partes do mundo: da cultura da terra. Produz trigo, milho e outros cereais, excelente vinho, muita azeitona, figos, uma quantidade de frutas, fumo, beterraba para fazer açúcar... Vive também das glórias do passado. Suas ruínas rendem dinheiro - deixado por lá pelos turistas que vão vê-las.

- Mas como pode a Grécia decair assim, vovó?

- Meu filho, a Grécia teve a desgraça de ficar à beira dum caminho muito trafegado. Não houve derrame de invasores da Ásia para a Europa e da Europa para Ásia que não passasse por cima dela. Só das avalanchas dos Cruzados, que todas as partes de Jerusalém bater nos turcos, a Grécia sofreu mais que os turcos. Além disso até bem pouco tempo andou como peteca, de tão conquistada por este ou aquele povo. Foi conquistada pelos macedônios, pelos romanos, pelos godos, pelos vândalos, pelos eslavos, pelos venezianos, pelos turcos... Só nas unhas dos turcos esteve dois séculos. Por fim irrompeu a terrível guerra greco-turca em que os gregos saíram vencedores, readquirindo a independência. Nessa luta tomou parte o poeta inglês Byron. Romântico que era, Byron veio defender na Grécia de hoje, a Grécia antiga que lhe esquentava a cabeça - e lá morreu.” [p. 222-226]

\section{"Península Ibérica"}

“- Que Salazar é esse, vovó?

- Um homem que pôs em ordem as finanças portuguesas. Um verdadeiro grande homem. Endireitar as finanças de um país é um trabalho de Hércules.” [p.247]

LOBATO, Monteiro. Memórias da Emília. São Paulo: Globo, 2007 (1936).

Não encontramos referências à Grécia.

\section{LOBATO, Monteiro. Dom Quixote das Crianças. S/ ed. São Paulo: Círculo dos Livros, s/d (1936).}

“- Bens vês, Sancho, que a Fortuna sempre deixa uma porta aberta. Escuta. Na falta de Rocinante, não me pejo de ser carregado pelo teu jumento até onde possa curarme das minhas feridas. Isto é dos livros. O bom Sileno, aio do deus Baco, entrou na cidade de cem portas (Tebas) montando um jumento. Levanta-te, pois; vai buscar o burro e partamos antes que caia a noite.” [p.195]

“- Que hão de dizer? - respondeu Sancho. - Dizem que V. Sa. não passa de um louco e eu dum imbecil.

- É sempre assim - filosofou Dom Quixote resignado. - A inveja nunca poupa aos heróis. Veja Alexandre, veja César ou mesmo o divino Hércules”. [p.253] 
LOBATO, Monteiro. Serões de Dona Benta. 22ed. São Paulo Brasiliense, 1994 (1937).

“- E a Polia? - perguntou Pedrinho.

- A polia - explicou dona Benta, é outra coisa velhíssima, já conhecida dos gregos no tempo de Arquimedes. Este grande sábio espantou um rei e toda sua corte, movimentando navios por meio de uma combinação de polias.” [p. 47].

“- Todos os povos antigos tinham a ideia da chateza e fixidez da terra prosseguiu dona Benta. - Mas lá entre os gregos, o povo mais que ainda apareceu sobre a terra, um sábio de nome Aristarco apresentou uma ideia nova: a terra e os planetas não eram parados - giravam em redor do sol. Toda gente se levantou contra ele, porque semelhante ideia contrariava o ensinado pela religião grega. Mas a religião que estava errada não Aristarco.” [p. 72]

"Os começos da astronomia estão no velho Egito, na velha Babilônia, entre os caldeus e outros povos da antiguidade. Muitos séculos antes de Cristo já eles tinham ideias certas sobre os planetas Mercúrio, Vênus, Marte, Júpiter e Saturno, como também já haviam batizado as constelações mais importantes. Mas os sábios da Grécia foram os primeiros a dar forma científica a esses conhecimentos. Os gregos eram eminentemente poéticos, de modo que reduziam todos os fenômenos da natureza a mitos lindos. As constelações não escaparam à 'mitificação'. Existem no céu duas estrelas de primeira grandeza, chamadas Betelgeuse e Rigel, que fazem parte da constelação da Grande Urso, lá perto da estrela Polar. Os gregos as explicavam por meio de um mito. Júpiter, o deus dos deuses, e também um grande pândego, aproximara-se por Calisto, uma bela ninfa. Mas Júpiter era marido de Juno, deusa ciumenta como qualquer mulher de hoje e Juno deliberou dar cabo de Calisto. Percebendo as más intenções da esposa e querendo defender Calisto, Júpiter transformou-a em ursa.

- Ah - exclamou Emília - então o negócio de virar uma coisa noutra, de que as fadas tanto gostam, é invenção velha - de Júpiter...

-Sim, Júpiter virou Calisto em ursa; mas Juno veio a saber e encarregou Diana, a caçadora, de matá-la em uma de suas caçadas. Vai Júpiter e descobre a combinação (porque os deuses eram danados para adivinhar o pensamento uns dos outros) e virou a ursa em estrela. Nasceu assim a Grande Ursa.

- E a Pequena Ursa?

- Um filhinho de Calisto, de nome Arcas, ficou sendo a Pequena Ursa, ao lado de sua mãe. Mas Juno percebeu a tramóia e, furiosíssima, foi ter com Oceano, o rei dos mares, ao qual pediu que nunca deixasse as duas Ursas 'deitarem-se' no oceano, como fazem as outras estrelas que não ficam no rumo do pólo. Por esse motivo ficaram as duas coitadinhas perpetuamente grudadas no céu, sem poderem nunca regalar-se com os banhos de mar que refrescam suas companheiras.

- Então os gregos, tão inteligentes, acreditavam que as estrelas se deitavam no mar?

- Poeticamente era assim. Como a terra está sempre girando, as estrelas dão a impressão de desaparecerem no oceano para reaparecerem na noite seguinte - como quem todas as noites vai para a cama. Juno condenou as Ursas a não repousarem nunca...

- Interessante o mito, vovó. Um dia precisamos estudar a tal mitologia grega. Pelo que sei dela, é uma das coisas mais lindas que os poetas inventaram. 
- Os mitos não foram inventados pelos poetas e sim pelo povo; os poetas apenas lhe deram forma literária. Os gregos batizaram as principais estrelas e constelações. Por isso há tantas trazendo nomes de deuses e heróis gregos. Mas os gregos não podiam ir longe no estudo do céu por falta de instrumentos.” [p.74]

LOBATO, Monteiro. O Poço do Visconde. São Paulo: Brasiliense, 1957 (1937).

“Emília fez bico.

- Asneira! Asneira! Acham asneira tudo quanto eu falo - mas nos momentos de aperto quem salva a situação é sempre a asneirenta. Só uma coisa eu digo: se eu fosse refazer o mundo, ele ficaria muito mais interessante do que é. Os homens são todos uns sábios da Grécia, mas o mundo anda cada vez mais torto. Juro que com isso que chamam asneira eu transformava a terra num paraíso...

Dona Benta ficou pensativa. Quem sabe se Emília não tinha razão”. [p.216]

LOBATO, Monteiro. Histórias de Tia Nastácia. 7ed. São Paulo: Brasiliense, 1957 (1937).

Não encontramos referências à Grécia.

LOBATO, Monteiro. Picapau Amarelo. 7ed. São Paulo: Brasiliense, 1957 (1939).

A obra tem como um dos seus principais assuntos a Grécia, sendo assim, não cabe selecionar trechos relativos ao tema.

Breve descrição do enredo: Os habitantes do país das fábulas decidiram morar no Sítio do Picapau Amarelo e com eles vão também os monstros da Grécia. Convivem juntos personagens como Dom Quixote, Capitão Gancho, Branca de Neve e o Minotauro, o qual rapta Tia Nastácia e a leva cativa ao seu labirinto.

LOBATO, Monteiro. O Minotauro. 7ed. São Paulo: Brasiliense, 1957 (1939).

A obra tem como um dos seus principais assuntos a Grécia, sendo assim, não cabe selecionar trechos relativos ao tema.

Breve descrição do enredo: Preocupados com tia Nastácia, Pedrinho, Emília e Visconde vão até a Grécia nos tempos heroicos resgatar a cozinheira. Enquanto isso, Narizinho e Dona Benta conhecem o ápice do governo de Péricles com suas construções e incentivos à arte. Na aventura, as crianças conhecem Hércules, o filho de Zeus.

LOBATO, Monteiro. A Reforma da Natureza. São Paulo: Globo, 2008 (1941).

“- Que está fazendo aí menina - perguntou a mãe de Rã, ao vê-la dividindo o misterioso pó.

- Estou 'bi' o que leva e traz para que me leve e traga - respondeu ela em linguagem da pitonisa de Delfos (na linguagem emiliana 'bi' queria dizer 'dividir em dois'). [p.18] 
“- Vê, Emília? - disse Dona Benta. - Nem todos os livros devem ser comestíveis, mas só os de importância secundária, meramente recreativos, ou então os livros ruins. Um livro que não presta para ser lido, ao menos que preste para ser comido. E agora? Como vou passar sem a minha Ilíada e o meu Shakespeare?

Emília concordou que realmente nem todos os livros deviam ser comestíveis e, indo à biblioteca 'descomestilizou' a maior parte - menos os 'ruins'.” [p.44]

“A negra bebeu um gole e continuou nos 'ah-ah-ah’ de quem perdeu o fôlego, só que mais molhados. Por fim depois de uns cinco minutos, conseguiu desatar a língua.

- Vamos embora daqui, Sinhá. O sítio está enfeitiçado. Nem queira saber o que eu vi lá na grota...

- Mas que foi? Fale...

- Um bicho impossível Sinhá... Pior que o Minotauro. Era tanta perna... [p. 60]

LOBATO, Monteiro. A Chave do Tamanho. 17 ed. São Paulo: Brasiliense 1979 (1942).

“- Estou vendo que toda a cultura humana, guardada nas bibliotecas, está perdida. Tirar os livros das estantes já vai ser quase impossível. Abri-los é um trabalho e lê-los, letra por letra, caminhando de pé por baixo das linhas, é esforço lento e fatigante. Será uma verdadeira façanha de Hércules ler um livro todo.” [p.99]

\section{LOBATO, Monteiro. Os Doze trabalhos de Hércules. 10ed. São Paulo: Brasiliense, 1960 (1947).}

A obra tem como um dos seus principais assuntos a Grécia, sendo assim, não cabe selecionar trechos relativos ao tema.

Breve descrição do enredo: Os trabalhos de Hércules foram publicados separadamente em 1944 em doze fascículos. Eles narram à volta da turma do sítio à Grécia reencontrando Hércules e ajudando o herói a cumprir suas doze façanhas.

\section{LOBATO, Monteiro. Fábulas. 8 ed. São Paulo: Brasiliense, 1957 [1922] \\ “As ninfas de Emília.”}

"Quando, na sua viagem à Grécia, Emília teve notícia da existência de ninfas, dríades e hamadríades nos bosques, sua primeira ideia foi: 'E se eu fizesse no sítio uma criação de ninfas? Temos lá borboletas azuis, temos uma quantidade de passarinhos e aves que piam, como o inambu e o uru - mas zero ninfas. Vou ver se a deusa Flora me cede algumas'.

Isso foi daquela vez em que Pedrinho, Emília e o Visconde desceram juntos à Grécia Antiga para acompanhar Hércules em seus Doze Trabalhos. Entre certo trabalho e outro, Emília e o Visconde aproveitaram o descanso para uma chegadinha ao reino da deusa Flora. Como havia ninfas por lá! Volta e meia passava uma, leve como bolha de sabão com forma humana - forma esvoaçante. 'As ninfas não andam como nós' observou Emília. Elas deslizam. Parece que não tem peso nenhum. 'E que diferença há entre dríade e hamadríade?' 
O Visconde explicou que dríade era a ninfa de uma certa árvore, que vivia sempre ali em redor dela; e hamadríade era também uma ninfa dessa árvore, mas que vivia dentro do tronco.

- De castigo?

- Não. Como uma alma. Nossa alma não vive dentro do corpo?

Emília achou que a Natureza andava errada naquilo de prender ninfas dentro dos troncos, 'porque há de ser tortura horrenda isso de viver entalado, sem o menor movimentozinho - nem piscar o olho. Vou pedir a Hércules para fender todas essas árvores e soltar as pobres hamadríades...’

- Acha que estas ninfas daqui poderão acostumar-se no sítio de Dona Benta?

- Tudo é possível. Só experimentando.

- Pois vou experimentar - resolveu Emília. Vou ver se Flora me cede um lote aí de meia dúzia. Ela vai receber-nos em seu palácio hoje à tarde. Assim que houver um jeitinho, eu proponho negócio.

- Que negócio?

- A troca de seis ninfas por qualquer coisa.

- Que coisa? - quis saber o Visconde, já meio desconfiado que a 'qualquer coisa’ fosse ele, como acontecera lá no Oráculo Delfos.

- Não sei ainda. Na hora verei.

À tarde houve a recepção e Emília soube responder muito bem às perguntas da deusa.

- Quem é a rainha lá do reino de vocês? - quis saber a deusa e Emília, como todo o serelepismo: 'Sua Majestade Dona Benta I', e foi contando mil coisas do 'Reino' do Picapau Amarelo, metade verdadeiro, metade invenção.

- E quem é este senhor tão sério que a acompanha? - indagou a deusa, dando um piparote na cartola do Visconde.

- É um velho carregador da minha canastrinha. E um grande sábio também. Não há o que ele não saiba - até logaritmos.

A deusa Flora ignorava o que fossem logaritmos e quis saber, mas Emília (que também não sabia) embrulhou-a, fazendo uma tal mistura com mangaritos, que deixou a deusa atrapalhada. Em seguida propôs o negócio da compra de seis ninfas.

Flora surpreendeu-se. Pela primeira propunham-lhe um negócio daquela ordem. Compra de seis ninfas! Era boa...

- E com que moeda me paga esse lote de ninfas? - perguntou - e com muita surpresa viu Emília piscar e com um movimento de lábios indicar o Visconde. Seria possível que ela usasse o seu carregador de canastra como moeda?

Só naquele momento Flora prestou atenção no Visconde. Botou-o no colo, examinou-o. Fê-lo falar e por fim disse: 'É o mais maravilhoso boneco de engonço que ainda vi. Quem o fez?'

- Não é boneco, deusa! - explicou Emília. É personagem.

Flora não apanhou lá muito bem a diferença e estiveram uns minutos debatendo o assunto. Por fim disse:

- Seja boneco ou personagem, acho-o muito engraçadinho. Faço o negócio. Troco-o por seis ninfas. Só não sei como fazer chegar essas ninfas ao tal Picapau...

- Isso não me preocupa - respondeu Emília. Tenho uma boa dose do Pim aqui no bolso, e sacando um canudinho de taquara, tapado com um batoque de pau - obra do canivete de Pedrinho, explicou as maravilhas do Pim, deixando a deusa de boca aberta. Apesar de deusa, Flora sentiu inveja daquela criaturinha humana, possuidora de semelhante talismã. Seria humana ou alguma deusa também? Deusa de algum outro mundo? E começou a olhar para Emília com respeito e certo medinho. 
Mas iria Emília realmente trocar as ninfas pelo Visconde, um velho amigo seu? Não! Jamais semelhante coisa lhe passara pela cabeça. A ideia de Emília era fazer o negócio e entregar um Visconde 'imitação', feito por tia Nastácia - ou um fac-símile. E combinou com a deusa: 'Agora nós vamos com o lote de ninfas, depois o Visconde vem sozinho'.

- Por que já não o deixa aqui? - perguntou a deusa.

- Porque ele tem de arrumar os seus logaritmos e dizer adeus aos parentes.

- Que parentes tem?

- As palhas e os grãos de milhos que há lá no reino. Tem também de despedir-se dos fubás, das maizenas, das canjicas, das pamonhas, dos curaus...

A deusa Flora admirou-se duma figurinha como o Visconde ter uma parentela tão grande...

Tudo combinado, operou-se a partida. Flora convocou todas as ninfas do seu Reino e passou-as em revista, levando Emília pela mão para que escolhesse as seis. $\mathrm{O}$ trato fora de seis ninfas 'escolhidas'. A fim de que as ninfas escolhidas não desconfiassem, quando ela gostava de uma dizia para a deusa na língua do P:

- Espestapa! (Esta)

A deusa entendia mas a ninfa não - e saindo da fila vinha colocar-se ao lado do trono. Quando se completou o grupo das seis, Emília ofereceu a cada uma delas uma flor polvilhada com pó de pirlimpimpim, dizendo:

- Se forem capazes, cheirem essas flores, todas ao mesmo tempo mas sem espirrar - e as bobinhas, pensando que era um simples brinquedo (o brinquedo de cheirar e não espirrar), cheiraram as flores, enquanto Emília dizia: Um, dois e TRÊS!...

Fim!... Seis fiuns e lá se sumiram as ninfas, para irem reaparecer no pomar do Picapau Amarelo, tontinhas, coitadas, e muito surpresas de se verem no meio de plantas desconhecidas - mangueiras, jabuticabeiras, pitangueiras, por entre as quais passeava ron, ron, ron - um leitãozinho gordo, de fitinha na cauda, o Senhor Marquês de Rabicó. E viram também um animal monstruoso, que elas desconheciam, conversando com um burro: Quindim de prosa com o Conselheiro. Assustaram-se as pobrezinhas, e quiseram voltar para o Reino-de-Flora - mas como?

Enquanto lá no pomar as seis ninfas se entreolhavam, sem saberem o que fazer, no Reino-de-Flora, Emília cochichava ao ouvido da deusa:

- Não o deixo aqui porque Visconde agora tem de me acompanhar até lá. A senhora bem sabe que uma menina como eu não pode fazer sozinha uma viagem tão longa.

- Que perigo há?

- É boa! Os perigos do ar, deusa! Corujas, morcegos...

- Mas jura que me devolve o Visconde? - insistiu Flora, sempre com medo de que a Emília lograsse.

- Juro pelo chifre do Quindim que amanhã sem falta a excelsa deusa Flora receberá aqui o Senhor Visconde de Sabugosa, enviado lá do Reino de D. Benta I pela Marquesa de Rabicó.

- Quem é essa marquesa?

- Esta sua criada!

- E Sabugosa é o nome do Visconde de cartola?

Emília respondeu que sim. Em seguida vieram os adeuses. Houve abraços e beijos, terminados os quais Emília deu uma pitada de pó a Visconde e reservou outra para si. Cheiraram-nas ao mesmo tempo e fiun!... Sumiram-se os dois.

Assim que acordou lá no sítio, Emília correu em procura de tia Nastácia. Encontrou-a fervendo pêssego salta-caroço para fazer uma pessegada. 
- Depressa, Nastácia! Largue tudo e me arranje um Visconde fac-símile. Já, já...

- Que fogo é esse, diabinha? Parece que comeu brasa...

- É que fiz um negócio; comprei uma coisa e tenho que pagar com um visconde igualzinho ao nosso, mas fac-símile.

- Que história é essa?

- Fac-símile quer dizer 'de mentira’. A deusa está esperando.

- Que deusa?

- Flora...

A única Flora que Nastácia conhecia era uma neta da Nhana Baracho, meninota levada, que certa vez lhe havia jogado uma laranja podre. Julgou que se tratasse dela e ficou resmungando:

- Deusa, aquela sapeca? Era o que faltava! A pestinha me fez aquilo, mas quem faz paga. Neste mundo, Deus que me perdoe, a gente não pode fazer isto de mal pros outros, porque, mais dia 'menas' dia, paga mesmo. Me jogar uma laranja podre em cima! eu, uma velha!... Ela que espere que qualquer dia... Que é isso? Já aqui outra vez?

Era Emília que voltava do paiol com uma braçada de sabugo para que tia Nastácia escolhesse um.

A negra não teve remédio. Escolheu um e fez um Visconde falso bastante igual ao verdadeiro. A cartolinha saiu muito mal feita, mas servia. Restava apenas escreverlhe nas costas a palavra FAC-SÍMILE.

Por que isso? Porque Dona Benta tinha explicado certo dia que era um ato muito feio enganar os outros, impingindo uma coisa falsa por verdadeira. E que para evitar isso havia a palavra FAC-SÍMILE, destinada a ser impressa em tudo quanto fosse cópia de um original. Se eu duplico um objeto e marco a cópia com essa palavra, posso vendê-la sem nenhuma dor de consciência, porque não estarei enganando ninguém. Se Emília entregasse à deusa Flora uma cópia do Visconde marcada com a palavra FACSÍMILE, ela não estaria enganando a deusa e Dona Benta nada poderia dizer.

E Emília escreveu em letra de forma nas costas do Visconde falso: FACSÍMILE, mas pintou uma coroinha em cima. Aí é que revelou a sua malícia. A coroinha era de Visconde, de modo que a palavra 'Fac-símile' deixou de significar 'Cópia' e passou a significar um nome próprio: o Visconde de Fac-Símile... Por ter sido boneca, Emília considerava-se no direito de enganar aos outros, coisa que Pedrinho e Narizinho jamais fizeram.

Pronto o novo Visconde, tinha de levá-lo ao reino da deusa Flora e como era!

O pó de pirlimpimpim resolveu o problema - e na manhã do dia seguinte Emília cheirou uma pitada e deu outra ao falso Visconde, e os dois foram acordar nos domínios da deusa.

Que maravilha! O reino estava acordando. As flores ainda orvalhadas entreabriram suas pétalas para o sol. As abelhas começavam a sair das colmeias. Os passarinhos experimentavam as asas. As teias de aranha, com os fios recamados de gotinhas de orvalho, tornavam-se invisíveis com a evaporação. $\mathrm{O}$ ar estava impregnado de perfumes fresquinhos.

Emília despertou ao pé do trono da deusa, com o novo Visconde no braço. Flora desceu para recebê-los.

- Estou reconhecendo a figurinha que aqui esteve ontem e combinou comigo um negócio. Julguei que houvesse esquecido...

- Não me esqueci, não! - respondeu Emília já perfeitamente boa de tontura do Pim. Combinamos a troca de seis ninfas pelo Visconde de Sabugosa, e aqui o trago, mas com o nome mudado. Chama-se agora Visconde Fac-Símile.

- Por que mudou? - quis saber a deusa. 
- Porque descobriu que seus verdadeiros antepassados são os Condes de FacSímile e não os Marqueses de Sabugosa, como ele pensava - inventou Emília com o maior desplante, esperando que a pobre deusa não desconfiasse.

Mas dessa vez a esperteza de Emília não deu muito certo. Depois que ela se retirou, a deusa, desconfiada de qualquer maroteira, tratou de informar-se - além de que aquele Visconde não falava, não dava nenhum sinal de vida. E convencendo-se de que fora lograda, ficou furiosíssima. Tão furiosa que chamou o vento Éolo e disse:

- Vá lá no tal Picapau Amarelo e varra-me para cá as seis ninfas que aquela diabinha me surrupiou.

E Éolo foi e varreu o pomar como um tufão. Caiu manga verde como nunca, e todos os galhos que tinham broca vieram ao chão, e folhas só ficaram as novas e perfeitas. Mas Éolo não conseguiu arrancar de lá nem uma das ninfas.

- Por quê?

- Ah, porque Emília já estava lá e soube acudir a tempo. Com medo de que Flora descobrisse a sua maroteira e procurasse vingar-se, ela havia dito às ninfas:

- Olhem aqui: vocês são novas neste reino do Picapau e correm muitos perigos. O melhor é ficarem uns tempos como hamadríades, dentro dos troncos das árvores. Quando já não houver perigo de coisa nenhuma, eu as solto.

As seis ninfas, que estavam com frio (porque era mês de junho), aceitaram a ideia e permitiram que Emília, depois de com o machado faz-de-conta, abrir as seis maiores árvores do pomar, as encerrasse lá dentro, promovidas a hamadríade. De modo que quando Éolo chegou e sacudiu o pomar com a força de tufão, varreu quanta coisa frágil havia - mas não tocou nas ninfas... não pode levar para a deus Flora ninfa nenhuma, porque já não havia ninfa nenhuma no pomar do Picapau Amarelo. Só havia hamadríades muito bem escondidas dentro do tronco das maiores árvores e à prova de quanto vento há no mundo...

Este caso das ninfas foi uma das mais belas vitórias de Emília.” [p.267-276]

\section{“O centaurinho"}

"O fato mais importante daquele ano foi a trazida de um centaurinho para o mundo moderno. Toda gente sabia o que era centauro: um ser metade homem, metade cavalo. E não havia quem não tivesse visto uma pintura qualquer de centauro. Mas centauro de verdade nunca ninguém vira nenhum - nem seco ou empalhado nos museus. E vai, senão quando, que é que aparece no sítio de Dona Benta, em companhia de Pedrinho, Emília e do Visconde de Sabugosa, quando voltaram da Grécia Antiga depois das famosas doze façanhas de Hércules? Um centauro vivo, o centaurinho Meioameio, nome com que Emília batizou o potro de centauro que Hércules havia capturado nos campos da Argólida. Era um bichinho selvagem que rapidamente se educou, e quando os três picapauenses voltaram para o sítio, ele veio também - por gosto, não a força.

A volta da Grécia foi feita por meio do pó de pirlimpimpim, cujo funcionamento todas as crianças conhecem. Basta aspirar uma pitada, ouve-se um 'fiun!' e pronto! está chegado. Assim foi daquela vez. Pedrinho deu uma pitada de pó a cada um, todos a aspiraram ao mesmo tempo... e pronto, estavam chegados ao Sítio do Picapau Amarelo.

Quando Pedrinho voltou a si e se sentou, viu logo adiante um grupo formado por Dona Benta, tia Nastácia e Narizinho, todas de mãos na cintura, em redor duma 'coisa' estirada no chão e ainda profundamente adormecida: o centaurinho. 
- Não estou entendendo nada - dizia a negra. Minha vista não é boa, mas o que eu vejo é uma mistura de cavalo e cavaleiro. Parece que os dois caíram, e o cavalo escondeu as pernas do cavaleiro e o cavaleiro escondeu a cabeça do cavalo...

Dona Benta, que também tinha a vista fraca, achava que talvez fosse isso; mas Narizinho deu uma risada.

- Aqui não há cavalo nem cavaleiro nenhum, bobas. O que há é um centauro. Veja bem, vovó. O lombo, as quatro pernas e a cauda são de cavalo; mas em vez de pescoço e cabeça temos aqui (e mostrava com o dedo) um torso de homem do umbigo para cima - e uma cabeça com uma carinha linda. Trata-se, portanto de um centauro ainda menino, ou ainda potrinho...

Ao ouvir aquilo, tia Nastácia benzeu-se três vezes com a mão esquerda, murmurando o seu famoso 'Credo!'

- E Sinhá deixa que este bicho sem propósito acorde e fique morando aqui no sítio?

- Não sei, Nastácia. Isso depende de Pedrinho - que lá vem e bem acordado.

Pedrinho, que havia caído a uns cem passos de Meioameio, vinha vindo a correr. Abraçou Dona Benta, abraçou Narizinho e disse: 'Não tenham medo, é mansíssimo, e o mesmo que um irmão meu.'

- E chama-se Meioameio, nome que eu dei, xeretou Emilia, que também já despertara e viera correndo. Mansíssimo! No começo, quando Lelé o pegou...

- Que Lelé é esse, Emília? - interrompeu Dona Benta.

- Hércules. No começo quando Lelé o pegou com a boladeira num bando de centauros que passavam no galope, eu queria que a senhora visse como o coitadinho se debateu! Mas amansou logo, porque é inteligentíssimo e compreende tudo.

Nesse momento Meioameio deu o primeiro sinal de si: estava acordando. Abriu um olho, depois o outro. Sentou-se nas patas traseiras - e ao dar com Pedrinho riu-se.

Pedrinho fez as apresentações. 'Está aqui é a vovó, Dona Benta de Oliveira; e está é a célebre Narizinho de quem tanto falei lá na Grécia. E esta pretidão é a famosa tia Nastácia, que já esteve morando uns tempos no labirinto do Minotauro, lá na ilha de Creta.

E voltando-se para Dona Benta e Narizinho:

- Ele sabe tudo a respeito da vida aqui no sítio, porque nas nossas viagens (que eu fazia montado nele), a distração minha e o gosto de Meioameio eram a nossa vida aqui e as aventuras do Pim. Está tão afiado nas nossas aventuras que até aguenta um exame. Pergunte-lhe alguma coisa, Narizinho, para ver.

A menina perguntou: 'Que foi que encontramos chorando na Via-Látea, na nossa viagem ao céu?'

- Um anjinho de asa quebrada que depois recebeu de Emília o nome de Florzinha das Alturas - respondeu Meioameio com a maior segurança e prontidão.

Apesar da estranheza que era a presença de um centauro no sítio de Dona Benta, uma semana depois já estavam tão familiarizados com ele como se ali tivesse nascido e vivido a vida inteira.

- E em que língua se entendiam?

- Ora, na 'língua da Emília', que era a 'língua geral’ de todos ali - o rinoceronte, a vaca mocha. A 'língua da Emília’ era uma mistura de português, castelhano, gíria, expressões inglesas como 'All right', 'Okay' e 'Mind your business' (cuide do seu nariz) tudo misturado com caretas, micagens e gestos de todos os tipos, pinotes, botamentos de línguas, espirros e até pontapés. A palavra 'atenção', por exemplo, fora substituída por um pontapé na canela. Era tão expressiva a 'língua da Emília', que um filólogo inglês, que pousou uma noite no Picapau Amarelo, disse mais tarde a Bernard 
Shaw: 'A língua universal, com que há tanto tempo a humanidade sonha, não é em nenhuma que se está formando, e sim no maravilhoso sítio de Dona Benta' - e consta quer Bernard Shaw tomou a seguinte nota em sua carteira: 'Descobrir Emília e conversar com ela'.

O que foi a vida de Meioameio no sítio de Dona Benta requer para ser contado um livro de 300 páginas, e talvez um dia apareça com o título: 'Um Centauro no Mundo Moderno'; hoje vamos apenas narrar um casinho interessante que aconteceu.

Havendo o Visconde de Sabugosa entrado para a Academia Brasileira de Letras, Dona Benta, fez questão de ir ao Rio, com todo o pessoal do sítio, a fim de assistir à cerimônia de posse. A eleição do Visconde correra muito barulhenta graças à oposição dos ‘imortais’ que não tinham em casa filhos crianças e portanto ignoravam quem fosse o tal 'sabugo científico'. Emília, empenhadíssima na vitória do Visconde, teve de desenvolver uma atividade prodigiosa na remessa de leitões assados, cestas de jabuticabas, linguiças de lombo, farinha de milho de beijuzinho, quartos de paca, pencas de codornas e perdizes - e até de cambadas de lambaris do rabo vermelho (com algumas pirapitingas entremeadas), a fim de conseguir votos. 'É pela boca que se pega o 'imortal' - dizia ela.

$\mathrm{O}$ tal caso interessante aconteceu na viagem ao Rio e foi o seguinte. Ao embarcarem na Central, na estação mais próxima do Sítio do Picapau, o chefe do trem deixou que entrassem todos, até o Quindim, mas barrou Meioameio. 'Este não pode; é um passageiro não previsto no regulamento da estrada'. O centauro não podia ir em vagão de passageiro porque não era integralmente homem: e não podia ir em vagão de animais, porque não era integralmente cavalo.

A trapalhada foi medonha. Dona Benta não podia seguir viagem só com os outros e deixar Meioameio largado ali na estação, rodeado de basbaques, como acontecia sempre que ele aparecia em público. Se ele não embarcava, os outros também não embarcariam; a solidariedade era perfeita - e como agir? A pobre senhora telegrafou para o diretor da Central, para o Presidente da República, para os Ministros de Estado, para o deputado Barreto Pinto e até para o Embaixador da Grécia (o centaurinho era de nacionalidade grega). Nada conseguiu. As leis do país opunham-se terminantemente a que Meioameio viajasse em carro de passageiro por não ser integralmente homem, e em carro de animais por não ser integralmente cavalo. E o caso podia até determinar a ruptura das relações diplomáticas entre o Brasil e a Grécia, se a luminosa sugestão de Emília não fosse aceita.

- Qual foi a luminosa sugestão da Emília?

- Cortar as plataformas de dois carros, um de passageiros, outro de animais, e unir esses dois carros formando um só. Meioameio, então viajaria de pé no ponto de junção, com a parte-cavalo no carro de animais, e a parte-gente no carro de passageiros; e pagaria meia passagem como gente e meio frete como cavalo. Só assim pôde o centaurinho ser transportado de trem ao Rio de Janeiro sem que as leis e regulamentos da República dos Estados Unidos do Brasil fossem desrespeitados.

O Congresso Nacional chegou a votar uma moção de louvor a Emília pela inteligência com que salvou a Administração Pública dum terrível dilema: ou negar transporte a um passageiro ou infringir o regulamento duma estrada de ferro.

Temos aqui apenas um dos inumeráveis casos que a presença do centaurinho Meioameio no mundo moderno determinou, e que serão contados num livro grande - se as crianças quiserem.” [p.277-283] 


\section{“Uma pequena fada”}

Dona Benta e Narizinho foram à horta ver o tio Barnabé plantar mudinhas de morango numa leira muito bem estercada.

- Não estão juntas demais, José? - perguntou Dona Benta, que não gostava de plantas muito juntas. O negro velho endireitou o corpo, botou as mãos na cintura e depois de correr os olhos pelas três carreiras de mudinhas já plantadas, disse:

- A mó que não, Sinhá. Como este ano eu botei ‘menas’ esterco, a folharada vai ser menor; por isso juntei um tiquinho mais as mudas.

Dona Benta, que sempre teve muita confiança no tio Barnabé, deixou que ele fizesse como entendia. Depois da visita à horta, ela e Narizinho foram ao pomar e sentaram-se no banco tosco que Pedrinho e o Visconde haviam feito junto ao tronco da pitangueira da Emília.

- Por onde andará aquela diabinha? - indagou Dona Benta. De manhã passou por mim como um corisco e afundou no laboratório do Visconde. Andam tramando qualquer coisa.

Narizinho não disse nada; estava distraída a espantar com uma palhinha um grupo de formigas ruivas que se tinham atracado a uma pobre minhoca. Sem interromper a 'salvação', disse:

- Vovó: ando desconfiada de uma coisa...

- De que, minha filha?

- Ando cismado que Emília é uma fada que veio a este mundo sob forma de boneca e depois virou gente. Tudo em Emília são disfarces - até a vara de condão de todas as fadas.

- Não estou entendendo, minha filha - disse Dona Benta, erguendo os óculos para a testa.

- Pois eu estou; e estou cada vez mais convencida de que 'faz de conta' de Emília é uma varinha de condão disfarçada. Que diferença há entre o 'faz de conta' e uma vara mágica? Preste atenção nisso, vovó. Naquela aventura de Hércules com javali do Erimanto, por exemplo, Hércules estava perdido. Quando o javali avançou contra ele com ímpeto de avalancha, o coitado só dispunha duma arma: as cinco flechas de ponta de bronze que tinha no carcaz. A senhora sabe o que é carcaz, não?

Dona Benta riu-se.

- Sei, minha filha; é o canudo, ou recipiente, que os antigos arqueiros levavam à cintura para o transporte das setas. E você sabe o que é arqueiro?

Narizinho não sabia.

- É o flecheiro antigo - o homem, ou o soldado, armado de arco e flechas, nos tempos em que ainda não havia arma de fogo. A palavra arqueiro vem de arco, como espingardeiro vem de espingarda, carabineiro vem de carabina etc.

Mas continue a história. Hércules estava só com cinco setas no carcaz...

- ... e todas 'humanizadas', isto é, sem pontas. Em certa ocasião Emília deu de ter dó das vítimas de Hércules e 'humanizou' todas as suas flechas, isto é, quebrou-lhes a ponta. De modo que quando o javali investiu contra Hércules e ele o recebeu com a clava e a clava rachou em vinte pedaços e o grande herói teve de recorrer às flechas, estaria irremediavelmente perdido se não fosse o 'faz de conta' de Emília. O Visconde me contou tudo exatinho como foi. Assim que se viu sem a clava, Hércules deu tremendo salto para trás e botou uma flecha no arco e atirou. A flecha bateu no peito da fera, plaf, e caiu no chão, não entrou ma carne. Hércules deu outro pulo para trás e desferiu segunda flecha - e foi a mesma coisa: a flecha bateu no javali e caiu no chão. Com quatro flechas aconteceu a mesma coisa, e só quando ele ia lançar a quinta e 
última flecha, é que Emília recordou que havia "humanizado" todas as cinco e, portanto o grande herói estava perdido, ali diante do mais feroz javali que ainda apareceu no mundo e sem nenhuma arma para enfrentá-lo, nem um canivete! Vê que situação horrível, vovó?

Dona Benta achou que realmente a situação de Hércules não era nada boa, e que a ex-boneca havia cometido uma grande imprudência. 'Tudo neste mundo tem limites. Emília excedeu-se. Hei de fazer-lhe um sermãozinho sobre os perigos do excesso'. E depois, o que aconteceu?

- Aconteceu que quando Hércules ia lançar a quinta e última flecha, Emília teve a sorte de lembrar-se da 'humanização' e gritou, no instantinho em que a flecha ia escapando do arco: 'Faz de conta que essa tem ponta!' e a flecha adquiriu ponta e matou o javali!... Não acha isso maravilhoso, vovó? Não acha que coisas assim só as fadas conseguem por meio de suas varas de condão?

Dona Benta franziu a testa e ficou pensando; depois disse:

- Você tem razão, minha filha. Coisas assim só as fadas conseguem realizar. Não há dúvida...

- Logo, Emília é uma fada, vovó! Logo, o tal 'Faz de conta’ que ela tanto usa é uma vara de condão disfarçada...

- Sim, uma vara verbal...

-... porque as varas de condão podem ter todas as formas, e não só a de vara pelo menos eu penso assim.

- E pensa muito bem minha filha. A vara de condão de Aladino era uma lâmpada, a de certos mágicos é um anel, a dos sacis parece que é a carapucinha...”

[p.284-287] 


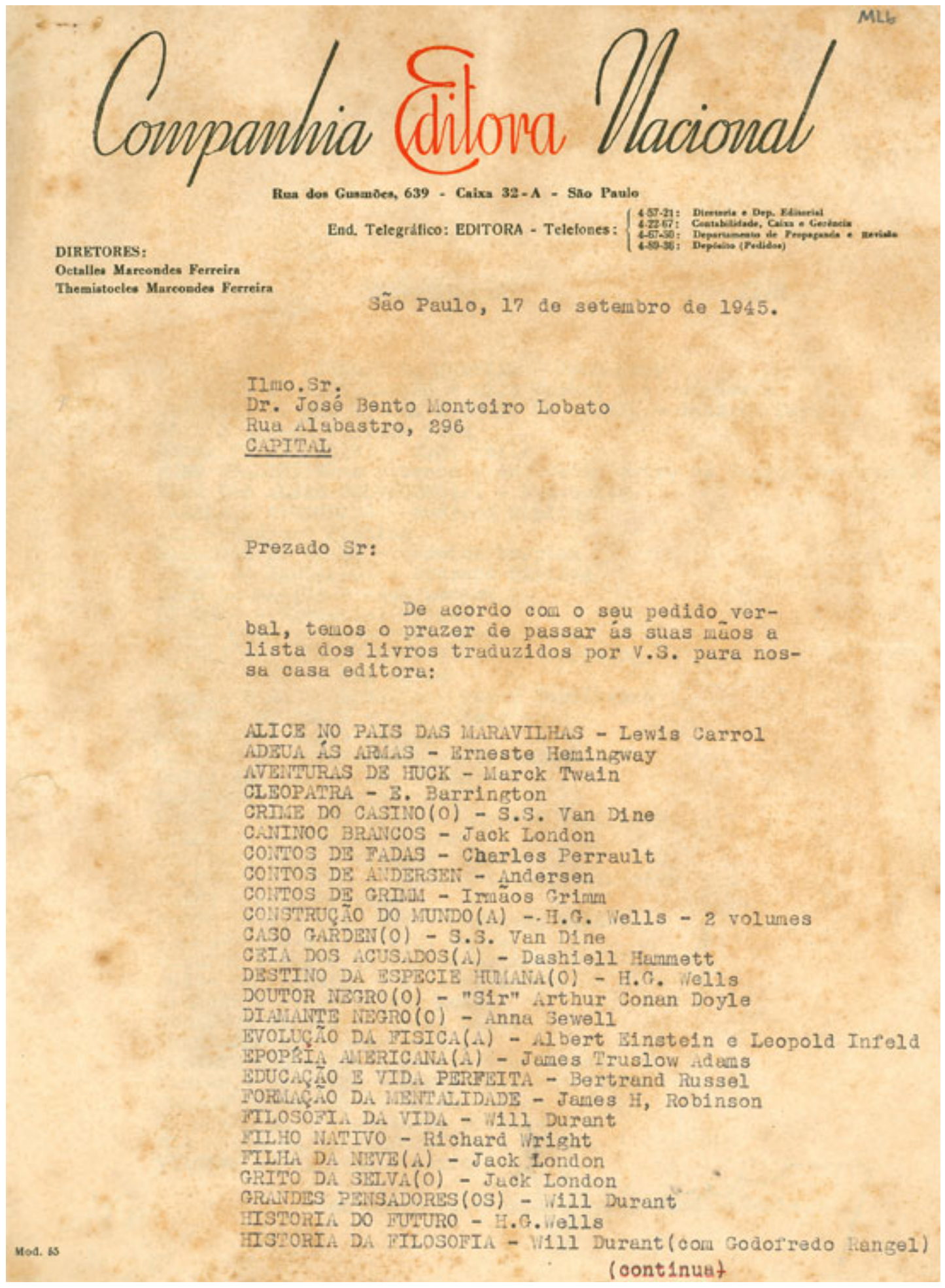




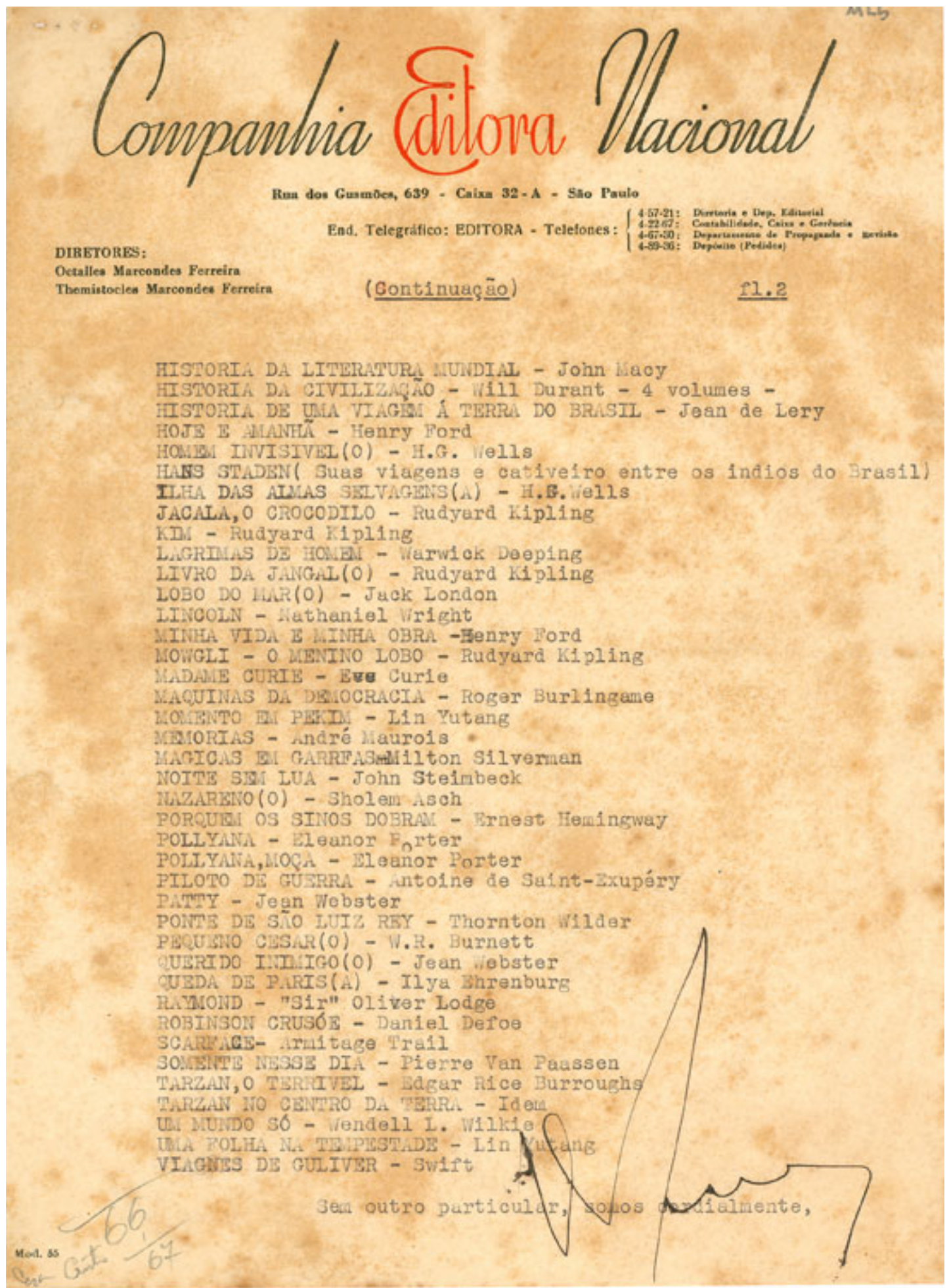




\section{ANEXO 2: Páginas de “O Leão de Neméia” com anotações de Monteiro Lobato (Biblioteca Infantil Monteiro Lobato)}

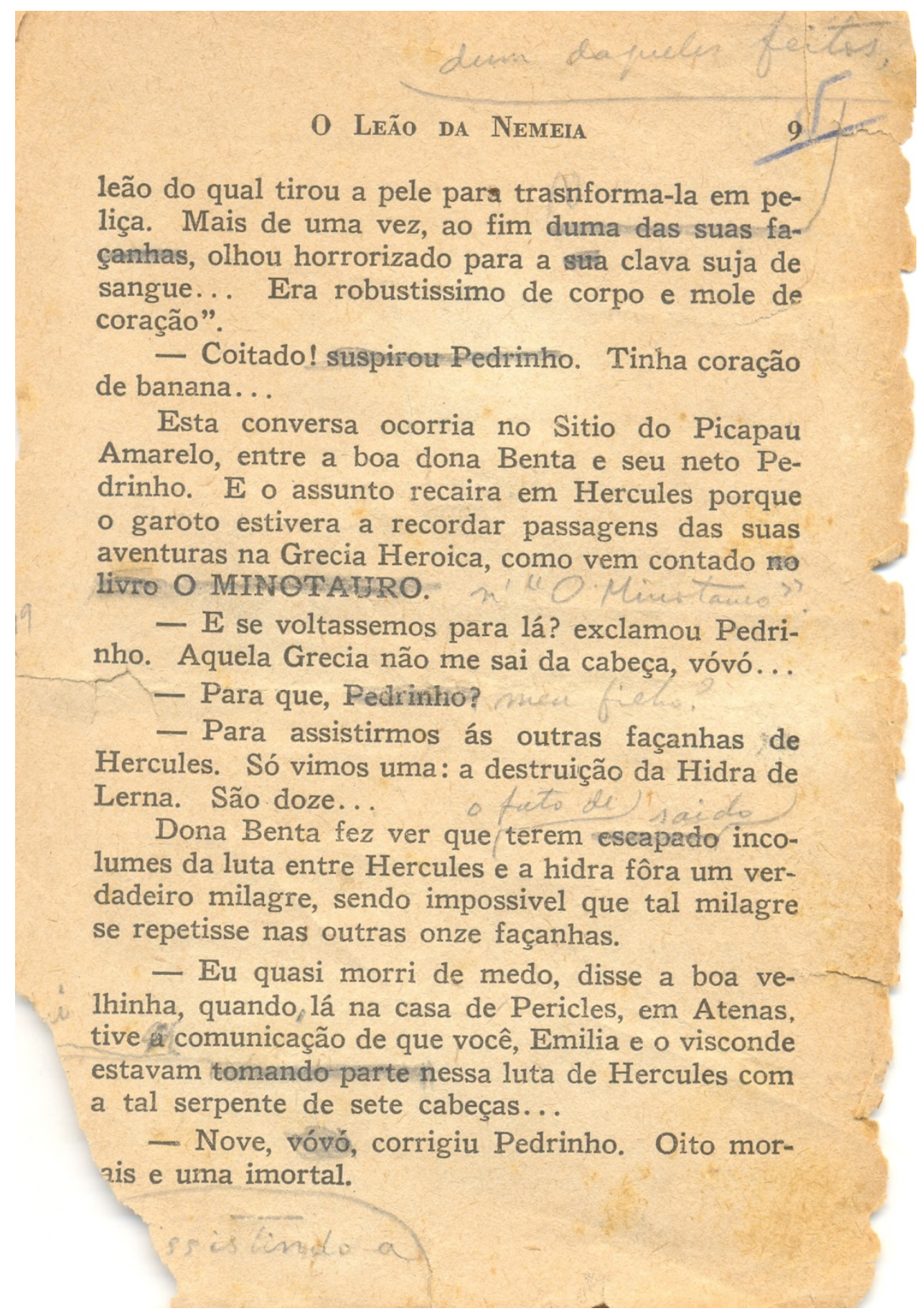


- Ou isso. Quasi morri de medo, porque bastava que uma simples gota do sangue da hidra espirrasse em vocês para irem todos para o beleléu...

Pedrinho danava com aqueles medos da vóvó. Sempre que ele sugeria alguma aventura nova, lá vinha ela com o tal medo e a tal pontada no coração. Resultado: ele metia-se nas aventuras do mesmo modo, mas escondido, sem licença dela. "Os velhos não entendem os novos", dizia Pedrinho. "Querem nos governar, querem nos obrigar a fazer exatinho o que eles fazem. Esquecem-se de que se fosse assim, o mundo parava - não havia nada novo... E note-se que vóvó não é como as outras velhas. No começo não quer, se opõe; mas se realizamos ás escondidas alguma aventura, assim que vóvó sabe faz uma cara de espanto e de zanga, mas esquece logo da nossa desobediencia e gosta, e ás vezes ainda fica mais entusiasmada do que nós mesmos". E Narizinho acrescentou: "Vóvó diz que não só por dizer, porque o tal "não" sai da boca dos velhos por força do habito. Mas o "não" de vóvó quer quasi sempre dizer "sim"...

D. Benta opôs-se a que Pedrinho voltasse á Grecia para tomar parte nas onze façanhas do grande heroi, mas opôs-se dum modo que era o mesmo que dizer: "Vá, mas escondido de mim..." e Pedrinho exultou.

- Falei com vóvó, foi ele correndo dizer a $\mathrm{Na}$ rizinho, e ela veio com aquele "não" de sempre, que nós traduzimos por "sim". Vou mandar o viscond 


\section{O LeÃo da Nemeia}

- Nada, respondeu Emilia com a maior inocencia. Só que tenho muitas coisas a guardar e a canastrinha velha já está cheia.

- Eu sei, eu sei... resmungou a preta. P'ra mim, é reinação nova. Onde é? Vá - diga...

Emilia começou a inventar uma mentira bem arranjada demais. Todas as mentiras da Emilia eram assim: tão bem arrumadinhas que todos logo desconfiavam. A negra não acreditou em coisa nenhuma; mas, para se ver livre da atropeladeira, disse:

- Está bom. Faço, sim. Que remedio? Você quando quer uma coisa fica peor que carrapato... e á noite, no serão, fez a canastra nova do tamanho que a atropeladeira queria. Dona Benta apareceu e viu a negra entretida naquilo.

- Hum!... Canastrinha nova... Isso é sinal de Grecia. Pedrinho está com saudades de mais aventuras por lá.

- E sinhá deixa? disse Nastacia, lembrandis-se das aflições passadas no labirinto de Creta, quando andou ás voltas com o horrendo Minotauro.

- Eu já disse que não, respondeu a boa velha, mas Pedrinho não acredita nos meus "nãos". Eles querem acompanhar Hercules em seus outros trabalhos...

- Credo! exclamou a preta, sem saber cue

"traba Ihos" eram aqueles - e varizinho veiu podir á vóvó que falasse de Hercules.

Dona Benta falou. 
ANEXO 3: Termo de Doação do Acervo Pessoal de Monteiro Lobato à Biblioteca Infantil Monteiro Lobato (Biblioteca Infantil Monteiro Lobato)

\begin{tabular}{|l|l|l|l}
\hline & & \\
\hline
\end{tabular}

Sra. Diretora

Conforme entendimentos anteriores, solicitamos providências para que sejam incorporados aos bens patrinoniais da Prefeitura do Município de São Paulo, os móveis, documentós e objetos de uso pessoal que pertenceram ao escritor Monteiro Lobato e que foram doados por membros de sua família a Biblioteca Infanto-juvenil Monteiro Lobato, no ano de 1985, conforme consta em cópia do termo de doação - inclusive com a relação dos pertences doados - em anexo.

Pelo valor histórico que cada móvel, documento ou objeto possui e por sua peculiaridade, acreditamos ser necessário um tratamento diferenciado no que se refere 'a jả citada incorporação.

Desde já, agradecemos,

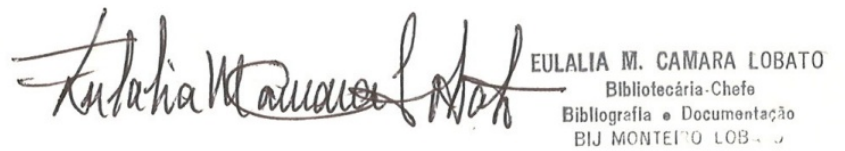




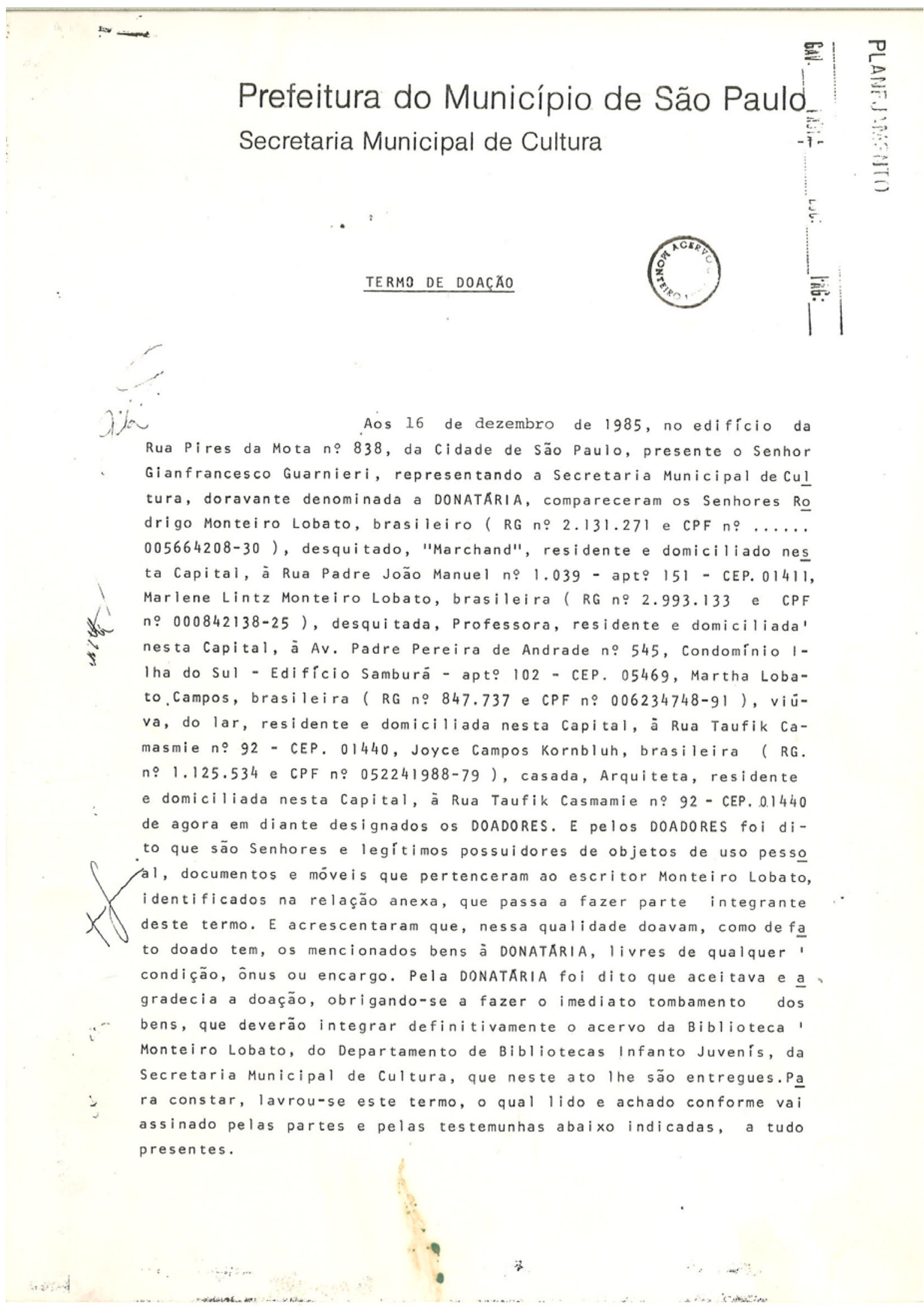




\section{Prefeitura do Município de São Paulo}

Secretaria Municipal de Cultura

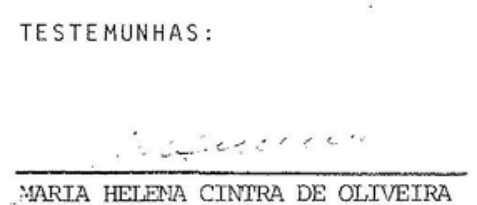

MARIA HEIENA CINIRA DE OLIVEIRA

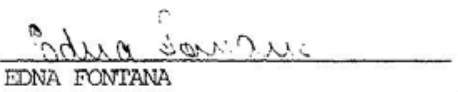

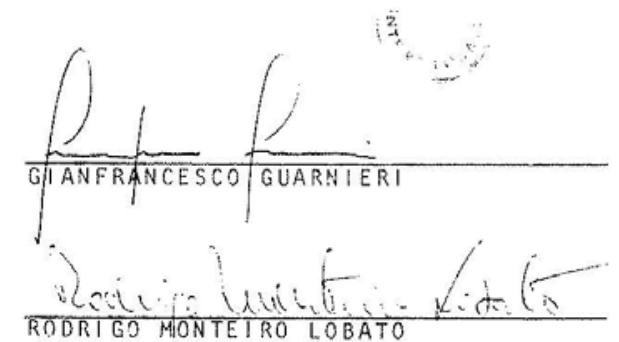

MARLENE LINTZ MONTEIRO LOBATO

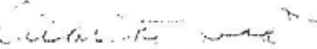
MARTHA LOBATO CAMPOS

$-\frac{\text { Heree }}{\text { JOYCE CAMPOS.KORNBLUH }}$ 


\section{Prefeitura do Município de São Paulo Secretaria Municipal de Cultura

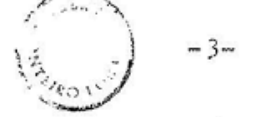

T. RELACÂO dE OBJETOS, E DOCUMENTOS DE MONTETRO LOBATO CEDIDOS À BI BLIOTECA INFAN'TL MONTEIRO LOBATO, POR SUA FAMILIA.

\section{DESCRIÇÃO}

- Pincéis à barba

- Navalha

- Aparelhos de gilete.

- Sabão para barba

- Carteira de Identificacão

- Acentador de fio de navalha

- Pedra de amolar of

Q1. - Pedra partida de amolar

- Calçadeira de sapato

- Seringa de injeção ok!

- Estojo de pintura aquarela

- Cortador de papel

- Carimbo

- Víaro de remédio homeopático

- Âlbum de fotografias de formatura

- Quadro de fotografia de Monteiro Lobato

- Pedaço de costela de Lobato

- Título de Eleitor no 56.994

- Disco com entrevista de Lobato

- Prato de porcelana com monograma de Lobato

- Chapéus

- Cachecöis

- Suspensôrios

- Gravatas c...

- Liga para meias ...

- Guaraa Chuvas

- Coletes

- Terno de vestir

- Calça.

- Sobretudo

- Manta

- Chinelo

K / - Caderneta de caução de água
QUANTIDADE

$$
02
$$

01

03.

01 .

(04) 03

01

01.

01

02

02

03

01.

01

01

01

01

01

01

01

02

02

03

07

01

01.

03

01

01

01

01

01. par

01 


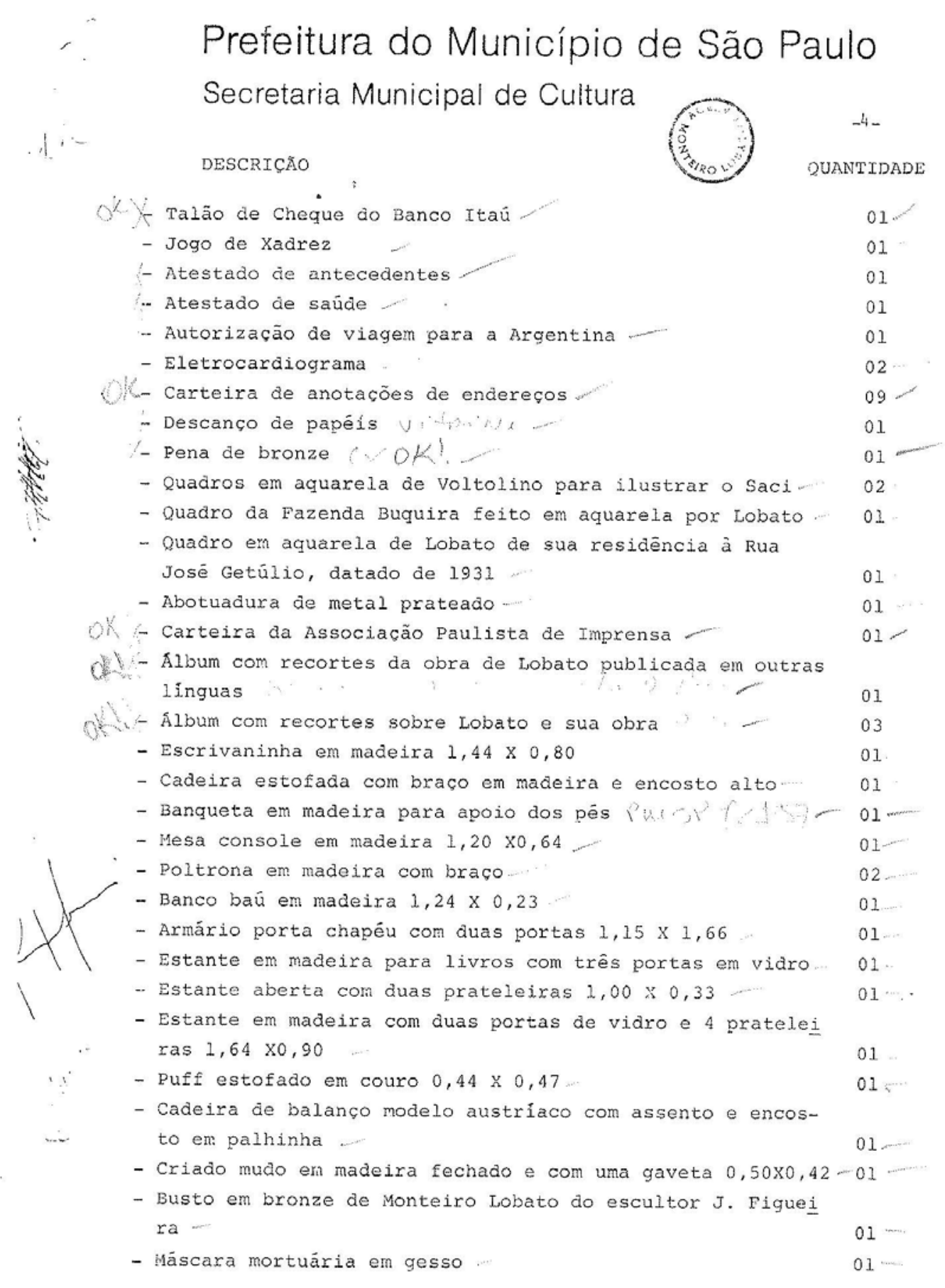




\section{Prefeitura do Município de São Paulo}

Secretaria Municipal de Cultura DESCRIÇÃO

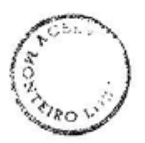
$-5-$

QUANTIDADE

- Caixa em madeira com tampo de vidro para máscara mortuāria $0,27 \times 0,31$

- Măscara mortuâria em bronze do escultor Victor Brecheret, com base em mārmore

- Escultura em bronze de autor desconhecido, intitulada La Garçonne

1.- Fotografias e negativos diversos

X-Correspondências diversa entre Lobato, seus editores,fainiliares e amigos

$X$ - Recortes de jornais sobre diversos assuntos

- Livros, revistas e folhetos que pertenceram a coleça particular de Lobato, alguns com anotações de próprio pu nho do autor, outros com dedicatória de amigos, parentes ou admiradores 


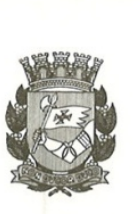

d O memo.

BIJ G.

Assistência Técnica

a/c. Sr. Nilton

Solicitamos análise e os seus préstimos quanto a essa incorporação, que se refere à doação ocorrida em 1985, quando SMC obrigou-se a fazer o imediato tombamento dos bens (não providen ciado até o momentol. Esclarecemos que os mesmos encontram-se nes ta Biblioteca, sob a responsabilidade da seção de Bibliografia e Documentação.

Sem mais para o momento.

S.P. $26 / 11 / 99$

Purvalina Soares Silva

Gla. Monteiro Lobato

Diretofa- BH. 11

\author{
07 \\ $26,11,99$
}


ANEXO 4: Folha de rosto da $1^{\text {a }}$ ed. de História da Civilização - Nossa herança clássica - A vida na Grécia

\section{Will Durant}

H IS T O R I A

da

QIVIIIDAOAO

2. Parte - NOSSA HERANÇA CLÁSSICA

A Vida na Grecia

Historia da civilização grega desde o seu inicio; e da civilizaçäo do Oriente Proximo desde a morte de Alexandre até á conquista romana; com uma introdução sobre a cultura prehistorica de Creta.

Tradução de

GULNARA DE MORAIS LOBATO

1. revista por

MONTEIRO LOBATO

TOMO $1^{\circ}$

COM PAN H IA EDITORA NACIONAL

SÃo PAULO - RIO de JANERO - RECIFE - PORTO ALLEGRE

1943 
DO ORIGINAL NORTE-AMERICANO:

\section{THE STORY OF CIVILIZATION}

2nd. volume: THE LIFE OF GREECE

Versão autorizada por

SIMON \& SCHUSTER, INC. - NOVA YORK

Direitos para a lingua portuguesa adquiridos pela

COMP. EDITORA NACIONAL - SAO PAULO

aue se reserva a propriedade literaria desta tradução. 


\section{ANEXO 5: Prefácio de Os Grandes Pensadores}

\section{Prefácio para a Tradução Brasileira ${ }^{166}$}

É-me agradável saber que um novo livro meu vai ser dado a um público sul-americano, embora o prazer que eu sinta sofra de apesar de que até agora não ter podido conhecer a América do Sul. Bem informado estou das belezas naturais dos países que a compõem e sei que o panorama do Rio visto do mar, e vice-versa, é uma das sete maravilhas do mundo moderno. Mas o que mais me fascina é o temperamento latino.

Também sou latino, um torturado da sensibilidade e um consumido pela imaginação, em luta para controlar o sentimento romântico pelo estudo do pensamento clássico, com supressão do poeta que sou em proveito duma suspeitável e bem domesticada prosa. Não me sinto em casa no norte, entre hábeis homens de negócio ou sutis diplomatas, ou fleumáticos hiperbóreos; meu anseio é pelo sul da França, pela Itália, pela Espanha, pela América do Sul - por países com sol no sangue e que não matam a ganhar a vida, mas vivem.

E por isso invejo aos meus livros, e desejaria poder segui-los para além do equador e viver algum tempo próximo ao Rio ou a São Paulo, aprendo a Língua que aí se fala, estudando a literatura e (nas entrelinhas) observando as mulheres, que são, afinal de contas, muito mais interessantes que os nossos livros. Mas se o não posso fazer, muita honra sinto em que minhas palavras o possam, e que por meio delas eu fale através de mares e continentes aos sulamericanos amigos dos gênios, e que se deleitam em conversar e refletir sobre os grandes homens. Sei que o espírito latino jamais cometerá o erro setentrional de conceber a história de um modo impessoal, como um movimento de massas, preços, salários e diagramas. É verdade que pequenas causas produzem grandes efeitos, mas essas causas operam sobre tudo através dos grandes homens e não há razão para que a história escrita não revele alguma coisa dos vícios da história vivida.

Os mais poderosos fatores da história são as ideias. Não necessitamos fazer muito esforço para compreender que, hoje são as ideias - invenções, religiões, filosofias, formas de pensamento falado ou escrito e formas de governo, ideias do indivíduo e da vida nacional - que movem o homem nas crises dos negócios internacionais. As ideias de Nietzsche, por exemplo, influenciaram profundamente Hitler e Mussolini; as ideias de Karl Marx transformaram a vida da Rússia; as de Spengler fazem que cada estadista ponderem sobre o futuro do seu povo e da sua civilização; as ideias de Flaubert influenciariam a metade da literatura da Europa e da América. Neste livro procurei interpretar algumas destas concepções básicas no campo da literatura e da filosofia. Estou convencido que as grandes coisas do nosso século não sairão dos campos de batalha, e sim dos nossos cérebros e dos nossos corações.

Great Neck, Nova York, 6 de maio de $1939^{167}$.

WILL DURANT

\footnotetext{
${ }^{166}$ Apesar de Lobato assinar como tradutor desta obra, esta “autoria” pode ser questionada pelo "estilo” e "linguagem rebuscada”, que descaracteriza os textos lobatianos.

167 DURANT, William. Os Grandes Pensadores. s/ed. São Paulo: Cia Editora Nacional, 1946.
} 
